

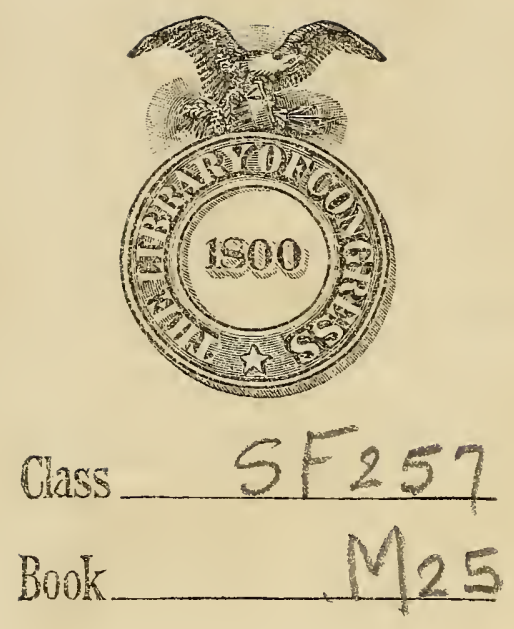

Copyight No

COPYRIGHT DEPOST: 


THE MODERN MILK PROBLEM 


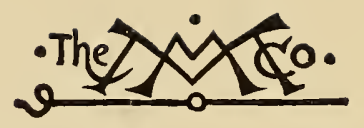

THE MACMILLAN COMPANY

NEW YORK - BOSTON - CHICAGO - DALLAS ATLANTA - SAN FRANCISCO

MACMILLAN \& CO., LIMITED

LONDON - BOMBAY - CALCUTTA

MELBOURNE

THE MACMILLAN CO. OF CANADA, LTD. TORONTO 


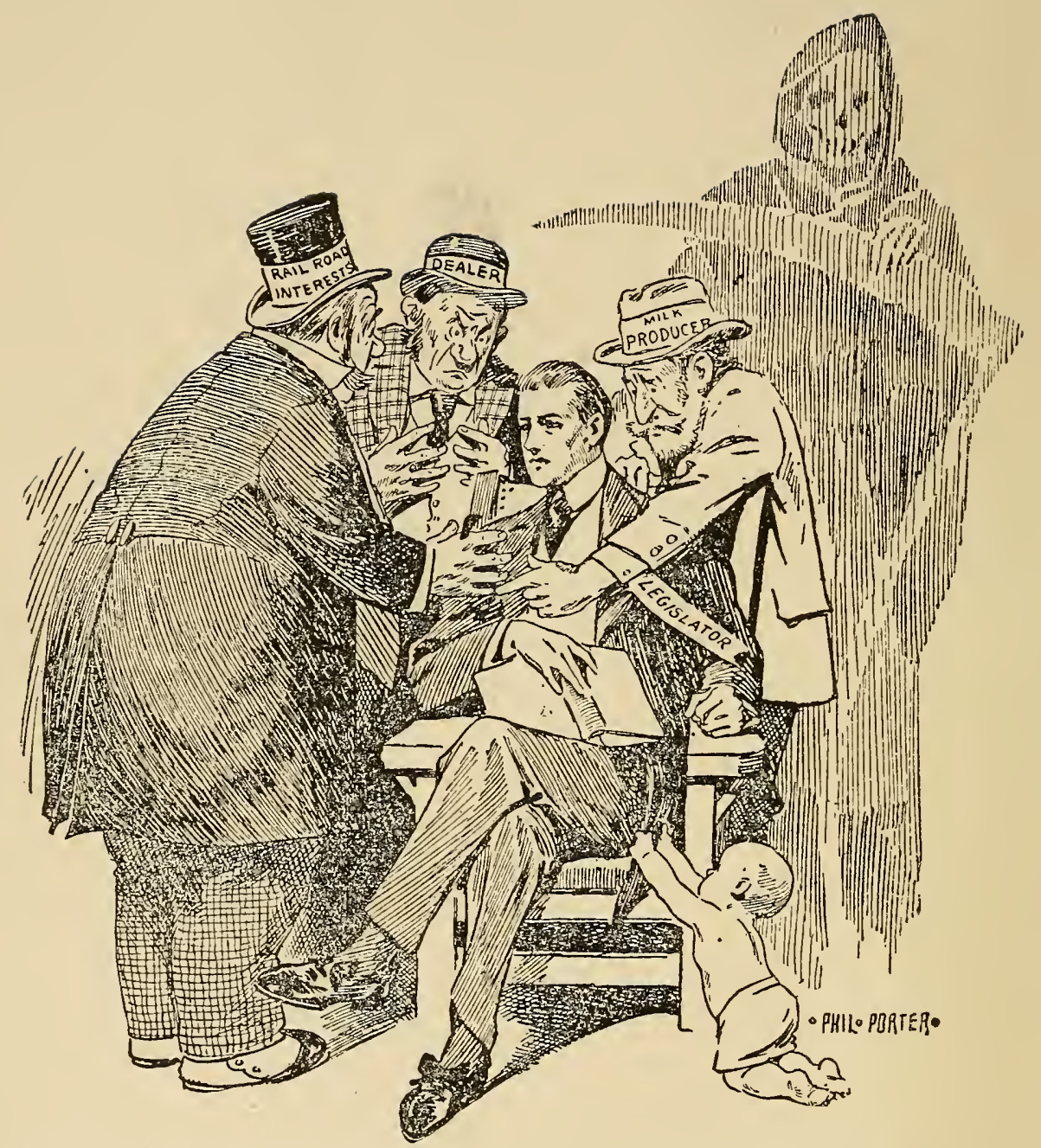

Milk in Politics-The Acute Stage of the Problem, as the cartoonist sees it. Under these circumstances the legislator is likely to suspend his dilemma by doing nothing at all.

Boston Herald, May 17, 1912. 


\title{
THE
}

\section{MODERN MILK PROBLEM}

\section{IN SANITATION, ECONOMICS, AND AGRICULTURE}

\author{
BY \\ J. SCOTT MACNUTT \\ LECTURER ON PUBLIC HEALTH SERVICE IN THE \\ MASSACHUSETTS INSTITUTE OF TECHNOLOGY; \\ AUTHOR OF "A MANUAL FOR HEALTH \\ OFFICERS"
}

\section{D̃au Hark \\ THE MACMILLAN COMPANY \\ 1917}

All rights reserved 


\section{$5 \times 2,57$
.925}

Copyright, 1917

BY THE MACMILLAN COMPANY

Set up and electrotyped. Published June, 1917.

\section{JUN 221917}

(C)

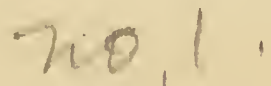




\section{PREFACE}

Notwithstanding the fact that the milk problem is constantly growing more acute in many parts of the United States, no book has thus far appeared treating, in a brief space, its main aspects and stressing the practical and economic as well as the sanitary factors involved. The present volume is designed to fill this obvious need by providing a convenient survey of a perplexing subject,-not merely for health officials and milk inspectors, but also for dairymen and city milk dealers, agricultural authorities, legislators charged with the framing of milk laws, inquiring consumers and members of organizations engaged in efforts to secure better milk supplies, physicians, and all others who are interested in the understanding and solution of the milk problem. 



\section{ACKNOWLEDGMENT}

The author desires to thank collectively the many correspondents who have assisted him in the collection of material, and particularly Mr. Franz Schneider, Jr., Sanitarian in the Department of Surveys and Exhibits of the Russell Sage Foundation, for his valuable criticism of the manuscript. 



\section{CONTENTS}

Chapter

I. Why There Is a Milk Problem............ 1

Nature and Importance of the Problem. Milk: A Cheap and Universal Food. Milk: A Sanitary Danger. The "Invisible Cloak" of Contamination: Dirt; Bacteria. Bad Milk and Infant Mortality. Milk as a Vehicle of Disease. Summary. A Practical Definition of "Pure Milk."

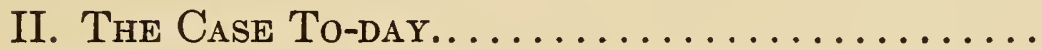

The Cry for "Pure Milk": Can Pure Milk be Got? The Modern Milk Problem: The Old-style Milkman-An Anachronism To-day; The Modern Milk Mechanism. The Parties in the Case: The Demands of the Health Official; The Pressure on the Farmer; The Farmers' Need of Organization; Agricultural Aid; The Position of the Dealer; Railroads-The Transportation Problem; The Attitude of the Consumer; The Physician; Unofficial Organizations; The Legislator-Milk as a Political Issue. Relative Importance of Milk Control. Conclusion: The State of the Case.

III. The Sanitary Factors. . . . . . . . . . . . . . . .

Early Developments. The Beginnings of the Clean Milk Movement: Certified Milk. The General Clean Milk Movement: The Score-card Method of Inspection; Rational Methods in Clean Milk Production-The North System; Amendment of the Dairy Score Card. Infant Welfare Stations. Laboratory Tests and Standards: Chemical; Bacteriological; Contamination Tests. The Tuberculin Test. Pasteurization: Methods; General Pasteurization the Insurance against a General Danger. Clarification and Other Processes. Publicity of Ratings. Contests, Conferences, Exhibitions. The Grading of Milk: Grading Systems. 
Chapter

IV. The Economic Factors. . . . . . . . . . . . . 121

Economic Value of Milk Production. Decline of Dairying in Certain Regions. The Crux of the Economic Question. The Plight of the Farmer: Is the Farmer Getting a Fair Price?; Another Aspect. Factors in the Final Cost of Milk. The Milk Dealer: Dealer and Farmer. Anomalies of Milk as a Commodity. Economic Effects of Sanitary Regulation.

V. How Solve the Problem?. . . . . . . . . . . . . . 152

The Great Need-Manifestation of Values: Principles of Grading; The Public Value of Milk. Costs and Prices. The Rôle of the Laboratory. The Rôle of Inspection: Dairy Demonstration. Organization and Administration: State and Local Legislation. Local Differences. Centralization, Cooperative Plans, Municipalization. The Gist of the Matter. Who Is to Solve the Problem?

References...................... 177

\section{APPENDICES}

A. Some Milk Statistics. . . . . . . . . . . . . . . . 185

B. Grading Systems.................... 189

C. The North System . . . . . . . . . . . . . . . 203

D. Costs and Prices....................... 214

E. Local Experiences and Investigations... . . . . 225

F. Milk Products..................... 253

INDEX . . . . . . . . . . . . . . . . . . 255 


\section{ILLUSTRATIONS}

Figure

Milk in Politics....................... Frontispiece

1. Composition of Cow's Milk, Showing Variations........ 6

2. Commercial Appeal on Economic Grounds............. 8

3. The Long $v s$. the Short Haul. . . . . . . . . . . . . 17

4. Systems of Milk Supply.................... 37

5-10. Typical "Milksheds" of Large Cities:

5. New York....................... 39

6. Philadelphia..................... 41

7. Boston.......................... 43

8. Chicago....................... 44

9. Washington.................... 45

10. Milwaukee.................... 47

11. The Small-mouth Milking Pail. .............. 79

12. Time and Temperature for Milk Pasteurization......... 104

13. Commercial Appeal on Sanitary Grounds............ 106

14. Commercial Appeal on Sanitary Grounds............ 107

15-20. Relative Retail Prices, 1890-1915:

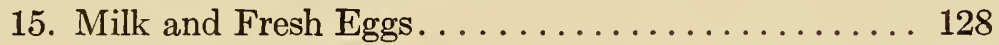

16. Milk and Potatoes. . . . . . . . . . . . . . 129

17. Milk and Round Steak.................. 130

18. Milk and Bacon..................... 131

19. Milk and Wheat Flour................ 132

20. Milk and Five Staple Foods............. 133

21. Retail Price of Milk Compared with Costs of Production.... 134

22. Profit from Different Cows...................... 135

Plate

1. Interior of a High-class (Certified) Dairy Stable. .opposite page 68

2. Ordinary Dairy Stables in Which Clean Milk Is Produced........................ " " 80

3. Ordinary Dairies and Extraordinary Dairymen. . " " " " 83

4. (a) Bacteria Plates, (b) Dirt Tests........... " " " 93

5. (a) Home Pasteurizer, (b) Results of Clarification " " 109

6-7. Primitive Conditions in the Milk Industry. . . . " " " 110

8-14. Advanced Conditions in the Milk Industry... " " " 110

15. Laboratory of a Large Modern Milk Plant..... " " " 145

16. A Small Municipal Milk Laboratory......... " " 166 



\section{THE MODERN MILK PROBLEM}





\title{
THE MODERN MILK PROBLEM
}

\author{
CHAPTER I \\ WHY THERE IS A MILK PROBLEM
}

That there exists to-day a large and, in many instances, acute milk problem is being increasingly recognized. Most persons, however, appreciate the nature of the matter no further than that it involves a "campaign for pure milk" which appears to them similar to the movements for other municipal improvements. Even to the well-informed citizen the factors and persons involved - the dairy farmer, the middleman dealer, the municipal official - appear in no distinct perspective; he is only vaguely aware of the contentions of these different parties, except as newspaper publicity may occasionally bring one or another of them to the fore; his interest usually goes no further than a jealous watchfulness of the price of the daily family supply; he entertains, therefore, no particular ideas as to improvements and readjustments and the ways of bringing them about. And this is no wonder when the officials and legislators to whom the public looks for remedies are themselves frequently puzzled for an answer to this much-debated question.

At the outset, therefore, the prime underlying considerations must be well borne in mind.

Among all food products milk gives rise to a peculiar 
question. One hears nothing, in any general and continuous sense, of a beef or a bread problem. Why, then, a milk problem?

That such exists is briefly explained by the conjunction of two conditions:

Milk is one of the most valuable and most largely used of all foods.

It is the food which is most apt, by far, to be dangerous to health.

This second condition depends very largely upon the fact that, in this country at least, milk has customarily been consumed raw, without the cooking, or halfcooking, which has always protected civilized man against infection in animal food.

"Milk," wrote Professor William T. Sedgwick, years before the problem reached its present acute form, "has always been one of the most trusted of human foods. Clothed in a veil of white; associated with the innocence of infancy; of high repute for easy digestibility; believed to represent in perfection a natural dietary, popular and cheap,-milk has always deservedly held a high place in public esteem. Of late years, however, while maintaining its reputation in respect to cheapness, food value, blandness and digestibility, it has, in the eyes of physicians and sanitarians at least, come to be regarded, while in the uncooked condition, with general suspicion." 1 *

This well-founded suspicion has developed with the rise of three branches of sanitary science: bacteriology, which has demonstrated the readiness with which milk may be contaminated and act as a medium for the

* Note numbers refer to list of references at end of Chapter V. 
growth of germ life; epidemiology, which has searched out countless instances in which it was the vehicle of disease; and vital statistics, which, in conjunction with clinical observation, has indicated the part played by bad milk in the preventable disease and mortality of infancy. The subject of safe, wholesome milk is therefore directly related to the two principal fields of modern public hygiene,- - prevention of communicable disease and conservation of child life.

The milk problem, as we shall find in the course of these pages, is characterized by complication and confusion. Its complications are due partly to the peculiar sanitary and economic conditions of the milk industry, and partly to the difficulties of harmonizing the several human interests involved. Milk is produced in quantities enormous in the aggregate, comes from animals liable to disease, and is handled by persons liable to diseases transferable by milk. It is, for the most part, under the care (or lack of it) of men whose education and experience know not the delicate science of bacteriology. It reaches the city consumer by a journey which is interrupted at frequent intervals for transference or handling, and at each stage there are chances of contamination and improper treatment. Finally, the consumer has no direct knowledge of its source, its history, and its sanitary quality when it reaches him. Even in the home, its final destination, it may, and frequently does, suffer impairment. Sanitary measures must be carefully devised and correlated, and even with an adequa,te force of officials-frequently not available-regulations are not easy to enforce. When strictly enforced they may arouse the antagonism 
of farmers and dealers who assert that they are entitled to additional recompense for the sanitary precautions they are obliged to take. The price of milk, which then comes into question, is notoriously a subject of jealousy on the part of all concerned. Those who deal with the question find, therefore, that they face not only a sanitary problem, but also an economic problem complicated by various human factors.

While the necessity of a safe, wholesome milk supply is the same for all communities, the difficulties of obtaining it are immensely increased in the case of the cities. The larger the community becomes, the farther it gets from the individual farmer and the nearer to the domination of the wholesale dealer and the complications incident to supplies drawn from many and distant sources. The milk problem is thus characteristically urban, but may exist in the smaller communities in greater or less degree.

Some of the reasons for the title of this volume have now been suggested. Under the conditions of modern, urbanized life a complicated milk problem has arisen, involving such questions as:

What is "pure milk"?

Is pure milk-or clean milk-or safe milk-or wholesome milk-practically possible?-and how can it be got?

Will the public pay for it?

The importance of the practical question is shown by the fact that it has invaded politics and has figured in a number of States and cities as a political issue. 
This development brings out the fact that the several interests concerned are often in conflict with regulation or with each other. The appearance of milk in the political forum is perhaps a sign hopeful rather than otherwise, as indicating that this greatest of food problems has become the subject of a public discussion which may lead to justice to all concerned.

\section{MILK: A CHEAP AND UNIVERSAL FOOD}

Whole milk contains all the elements of nutriment and combines them in readily digestible form in the proportions of a balanced ration. Hence its use as a substitute for mother's milk for infants, as an important component in the diet of children, as a special diet for invalids, and as a considerable portion, directly or indirectly, of the diet of all adults. Its value in these respects is such that it must be considered a necessity of civilization, being in this sense a universal food.

We need not here go into the details of the chemistry and dietetics of milk. Cow's milk varies in composition, but on the average good, unadulterated milk contains about 87 per cent water and 13 per cent solids. About one-fourth of these solids consists of protein compounds, i. e., tissue-forming and waste-repairing substances. Fats, in the form of butter fats, form one-third of the total solids. Butter fat occurs in globules throughout the milk, and it is upon the size and number of them that the creaminess of the milk consists. Carbohydrates, which, like the fats, are energy-producing or fuel elements, make up somewhat more than another third of the solids, the most important of them being 


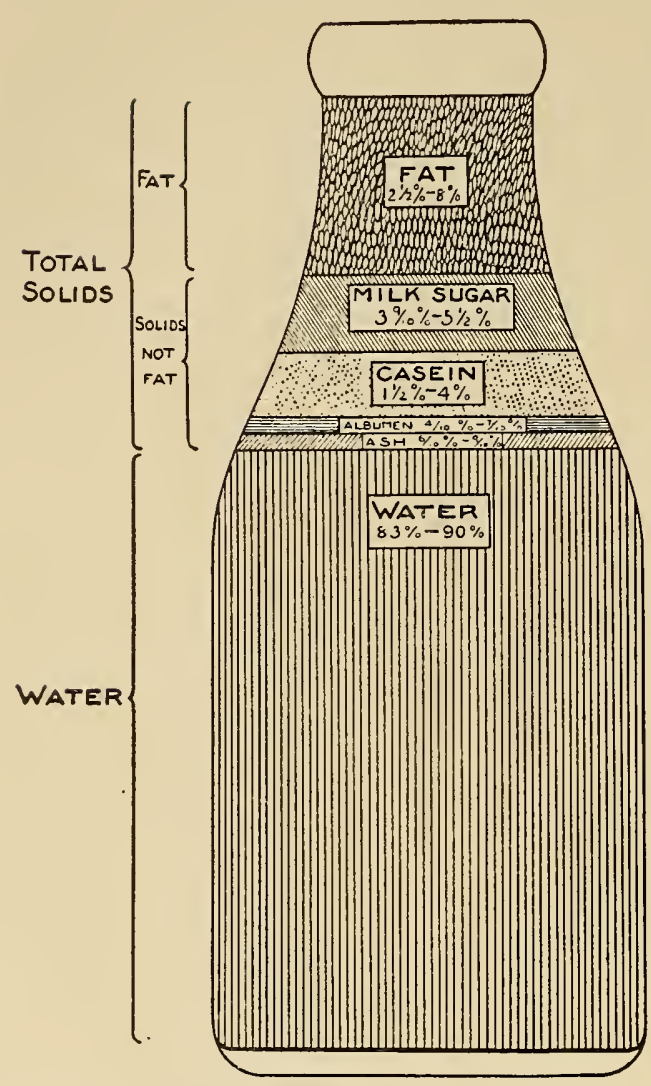

Fig. 1. Composition of Cow's Milk, Showing Variations

(Report on milk investigation, Boston Chamber of Commerce, 1915.)

lactose, or milk sugar. The remaining 5 per cent of the solids consists of mineral matter. Upon assumed allowable minima of these various components official requirements for "fats" and "total solids" are based.

The greatest variations are observed in the case of the fat content, which is most commonly taken as an index of the food value of any given milk.

Consideration of the uses of milk leads to the broad conclusion that it is a great staple, the lessened use of which, either through popular fear of its possible dangers or through a much increased cost of production, would be a grave disadvantage.

Pecuniary Economy of Milk as Compared with other
Foods

More important than purely abstract laboratory figures of food values is the question as to how milk compares with other foods in relative economy. Facts 
in this connection have been worked out and the following conclusions drawn from them by the United States Department of Agriculture:-

Bearing these things in mind, we see that milk at all but the highest prices assumed is a cheaper source of protein than any of the animal foods except cheese, very cheap meat, and salt fish. At usual prices skim milk furnishes protein more cheaply than any common animal food except salt fish. The protein of vegetable foods is less expensive, but, on the other hand, as prepared for the table is less thoroughly digested. Moreover, it is accompanied by such large amounts of carbohydrates that to secure much vegetable protein in the diet usually means an excess of the carbohydrates. Under ordinary market conditions milk, and even skim milk, is a cheaper source of body fuel than any of the usual animal foods except cheese and salt pork, but is a dearer one than the usual vegetable foods. Here again, however, the milk furnishes the ingredients in a form more readily and thoroughly digested than the vegetable foods as ordinarily served. Milk, then, is fully as economical a source of nutrients as most animal foods, but is dearer than most vegetable foods. It has the decided advantage of having no waste, requiring no time for preparation, and being more digestible than the vegetable foods. . . . Both whole and skim milk at moderate prices are therefore to be ranked among the most economical of foods not only when taken as beverages, but also when used in preparing other foods. ${ }^{2}$

Attention must be drawn, however, to the fact that with each cent's increase in price milk may lose, or seem to lose, its pecuniary advantage over some other article or articles (unless they also have risen), which then tend so far as possible to take its place. Sometimes the rival is a milk product, such as skim milk 


\section{Cost of Living}

In the past year 5 leading food products have risen in cost at an average of

\section{$64 \%$}

Potatoes advanced......114\%

Beans advanced.

$67 \%$

Codfish advanced...... 50\%

Eggs advanced........ $58 \%$

Butter advanced.

$30 \%$

The answer is use more

\section{'s Milk}

A Complete Food.

Clean - Pure - Safe

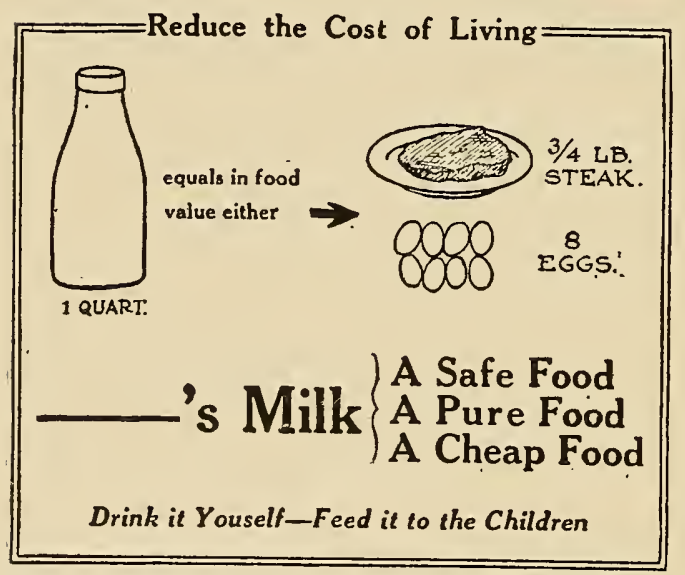

Fig. 2. Commercial Appeal on EcoNOMIC GROUNDS

This, if accurate, is a legitimate and useful kind of advertising based on the importance of milk as a food. or evaporated milk. Substances of less dietetic value are likely to be substituted in cookery, and its use as a table article may be stinted. At the same time a certain increase in price may be inevitable, especially when prices are going up all around, as they are at present writing. This question will be further considered in later chapters.

Science and $E x$ perience

The scientific deductions from the figures for food values and prices are confirmed in the ordinary widespread use of milk. About onesixth of the total food of the average American family is furnished by milk and its products. ${ }^{3}$ The average per capita use of milk (as such) in the United States is estimated by the De- 
partment of Agriculture at six-tenths of a pint daily, or a quart and one-half for each family of five. (See statistics, Appendix A.) This means that an enormous capital and an extensively ramifying system of equipment and operation are necessary to furnish the total supply. Besides the above amount of milk consumed as such (either drunk or used in cookery) must also be considered that large amount (about three times as much) which is made into butter, cheese, condensed milk, etc. Many of the considerations applying to milk as such apply also to these derived products.

The following reasons for the use of milk, adapted from a leaflet issued by the Massachusetts Dairy Bureau, summarize the matter in a general way:-

It is cheap.

It is nutritious.

It is easily digestible.

It is the best food for babies (mother's milk excepted).

It should enter liberally into the diet of children.

Many adults would be benefited by the use of more milk and less meat.

More milk used in cooking would add the cheapest nutrition of its kind.

Proper nutrition conduces to efficiency and long life,-in other words, to good health.

\section{MILK: A SANITARY DANGER}

The widespread use of milk has, however, another and an unfavorable aspect. While this universal food affords vast benefit, it is also, to a certain degree, the agent of disease. Of all foods it has in this respect the greatest potentiality. 


\section{THE "INVISIBLE CLOAK" OF CONTAMINATION}

\section{Dirt and Milk}

Though it is not fanciful to speak of milk as a symbol of beneficence, it must not be forgotten that its veil of innocence may hide possible dangers. Most white things readily show soiling; milk, as someone has remarked, stands almost alone in absorbing without obvious sign all but the grossest contamination. The amount of dirt-to use the mildest term-which can be added to a bottle of milk without visibly affecting its virgin whiteness is almost unbelievable. Of each dose of such contamination some is dissolved, some halffloats in suspension among multitudinous obscuring fat-globules, and some settles to the bottom, where least likely to be observed: only a fraction remains on the top or otherwise visible. The ordinary milk bottle tells no tales.

That the opportunities for such contamination under present-day conditions in the dairy industry are many is well recognized by all who are familiar with milk sanitation. In Fig. 3 is shown the long and broken route which may be required for country milk to reach the city consumer. At each stage of the journey is the possibility of contamination or deterioration of the product. Dirt and manure particles from the flanks and udder of the cow, hair and dandruff from her hide, the manurial dust of the stable, the questionable hands of the milker, the unclean milk pail contaminated with the decomposed dregs of the previous milking, or rinsed 
with polluted water, the unsavory straining cloth, imperfectly cleansed pans, further handling in process of bottling, bottles and other utensils of doubtful cleanliness, - these, together with lack of proper cooling and frequently many hours of transportation, are some of the details which demand the attention of the milk sanitarian. If, as Sedgwick suggests, drinking water were derived in the same manner and passed through the same processes as milk-drawn from the body of an animal standing in a stable, by the hands of workmen of questionable cleanness, and subsequently handled as milk frequently is - few would care to drink it. "It is clear," he adds, "that milk requires and deserves even more careful treatment than water, for it is more valuable, more trusted and more readily falsified or decomposed," and also, as we shall note presently-the most important consideration of allit is a readier agent of infection.

The dairy cow herself [as Dr. Charles E. North says] contributes a peculiar form of contamination. The udder is constructed like a sponge. There is a constant shedding of waste tissue from the lining of the udder. This udder waste often includes the products of udder inflammation. Such inflammations are so common they are present in some form in practically every dairy herd. Even when there is no external evidence there is often internal inflammation discharging its products with the milk. ${ }^{4}$

Now what is the sanitary significance of all this?

In the first place, no one wishes to eat or drink dirt, even that of the proverbial "peck of dirt." The various kinds of ordinary dirt may or may not be directly injurious to health. At the present time the tendency 
in sanitary science is to distinguish between the varieties that are, or may be, accompanied by infection, and those that ordinarily are not. Nevertheless dirt of any kind is in itself undesirable.

The instinct of decency is not without meaning. It is a protective instinct, and it is supported by the general fact that dirt is suspicious. There are places where dirt is naturally to be found, but when it is "matter out of place" it is a sign that something is wrong. We are not surprised to see muck in the gutter; we do not shudder at manure in a manure bin; but when we perceive foreign matter in a milk bottle we are rightly disquieted. The soiled hands of the daylaborer are the result of honest toil; the unwashed but milk-wet hands of the dairy worker excite revulsion.

This instinct has applications which are without sanitary significance. But in the matter of food it is truly protective. We have spoken above of "dirt" in a general sense. But ordinary dirt shades into filth, such as the manure of the cow stable: from contamination it is but a step to pollution, and pollution may mean infection.

It is possible to make theoretical distinctions between various forms of contamination, and it is possible to devise practical measures which lay stress upon the more dangerous. But both decency and experience aver that we should avoid all forms of contamination. Decency is, in short, a rough (though, as we shall see later, an incomplete) insurance of safety. But even though we are able to secure complete safety by other means, we should still desire the greatest degree of decency that we can obtain. Decency, as North points 
out, "distinguishes humans from animals. Decency adds pleasure and appetite to food. Cleanliness contributes most to decency. Milk may be safe because it is boiled but may be indecent because it is filthy." *

Bacteria and Milk

Dirt (using the word to include all forms of contaminating matter) in considerable quantities may be, in itself, more or less deleterious to health. But it is the associated bacteria which constitute the real objection or danger. Various forms of contamination are accompanied by various forms of bacteria, which may be more or less deleterious or dangerous. In the case of milk, they exert their effect upon the consumer either through their action upon the milk or through their infectious character.

1. Fermentation, Decomposition.-Many of these organisms thrive in milk, and in so doing alter its composition and excrete their waste products. The ordinary souring of milk is the usual form of fermentation. It may be argued that such a fermentation as this is not necessarily harmful, soured and fermented products being used as foods or even as remedies. The answer to this is that if such products are desired they should be obtained by known and controlled processes. The fermentation or decomposition of milk by miscellaneous, uncontrolled organisms is objectionable, and when the milk is to be used as food for infants and delicate persons it is dangerous. In every such process are produced greater or less amounts of substances

* Dr. North rates milks according to safety, decency, and price. (See p. 155.) 
which tend to make the milk an unfit or deleterious food.

The extent of such bacterial changes in milk from the time that it is drawn from the cow to the time it reaches the consumer depends upon three things: (1) the kinds and amounts of contamination, (2) the temperature of the milk, and (3) the time in transit. The contamination can be reduced to a minimum, the temperature can be kept low, and, if these two conditions are right, a reasonable time in transit can be allowed. Under practical circumstances some latitude must be permitted in the endeavor to approach the ideal,namely, that milk should be clean, fresh, and cold.

2. Infection.-A different case is that of infection. The germs of various diseases may gain access to milk, in which they live and frequently multiply. This is not merely a matter of contamination but of the transference of the secretions of already infected animals or persons. Relatively small contamination may in this case result in virulent and far-spreading specific infection. The unwashed hands of milker or milk-handler in an unrecognized stage of disease, infected manure from tuberculous cows, utensils which have been infected by washing in polluted water or in some other way: such are typical modes of infection. Polluted milk may at any time prove to be infected milk; it is, so to speak, a lottery of infection. Infection is possible even with a high degree of visible cleanliness, for infected individuals may be unrecognized and the transference of infectious matter undetected. Milk-borne disease, like other infection, "walketh in darkness."

Special reference must be made to carriers of com- 
municable disease. Bacteriology has demonstrated the existence of many persons who harbor and emit germs of disease without themselves showing any symptoms. Such carriers have been demonstrated with respect to typhoid fever, diphtheria, septic sore throat, and a number of other diseases. While the percentage of carriers in the population is small, the evidence is that there are, in the aggregate, many such persons and many others who manifest only atypical, unrecognized symptoms of the disease of which they bear the infection. Such facts must greatly increase the sense of insecurity with respect to the sources of disease. It scarcely need besaid that a proportionate number of carriers exists in the host of persons engaged in the handling of milk.*

There are two possible measures against infection in milk, to keep it out, or to destroy it if there. The difficulty or impossibility of keeping it out has just been indicated. There is immense importance, then, in being able to destroy it without material alteration of the milk. This, fortunately, can be accomplished by a form of insurance which will be discussed in another chapter-namely, pasteurization.

\section{BAD MILK AND INFANT MORTALITY}

Approximately one-fifth of the deaths occurring in the Registration Area of the United States are of in-

* It was estimated, for example, by Health Commissioner Lederle of New York City, in 1912, that about 127,000 persons were engaged in handling the milk supply of that city, and that there might be perhaps a hundred typhoid bacillus carriers alone in this army of persons. Rochester, N. Y., in order to guard against infection, by typhoid carriers, of milk to be sold raw, has adopted the requirement of a blood test for dairymen and their workers. 
fants under two years of age. The largest single cause of mortality among these infants is diarrhea and enteritis, to which one-quarter of the deaths is due. The latest available Census figures (1914) ascribe to this title in the Registration Area 43,532 deaths (under 2 years), which argues a total in the whole United States of some 65,000 . It is in this figure that we must look for the effects of bad milk so far as they are reflected in mortality. Unfortunately it is impossible to determine just what proportion of these deaths may be put down to bad milk as compared with such factors as improper methods of feeding and improper hygiene in other respects. We may, however, turn to some intensive evidence.

\section{Effects of Feeding Different Milks}

The normal and the best food, by far, for the baby is mother's milk. Such are the difficulties of artificial feeding under ordinary conditions that it is estimated that bottle-fed babies have only one-tenth the chance to live that breast-fed babies have. ${ }^{5 *}$

There are, however, cases in which artificial feeding is deemed necessary; besides which, cow's milk must always play a major part in the weaning of infants and the feeding of young children. Milk for infants should, if possible, be of the highest original sanitary quality. If the raw product is of a lower quality, it should be pasteurized. The evidence is that it should be pasteurized no matter what its quality.

* From a careful analysis of a three months' study, the New York City Health Department determined that almost two and a half (2.4) times as many infants were attacked by diarrhea among artificially fed as among breast-fed infants. (Weekly Bulletin, June.19, 1915.) 


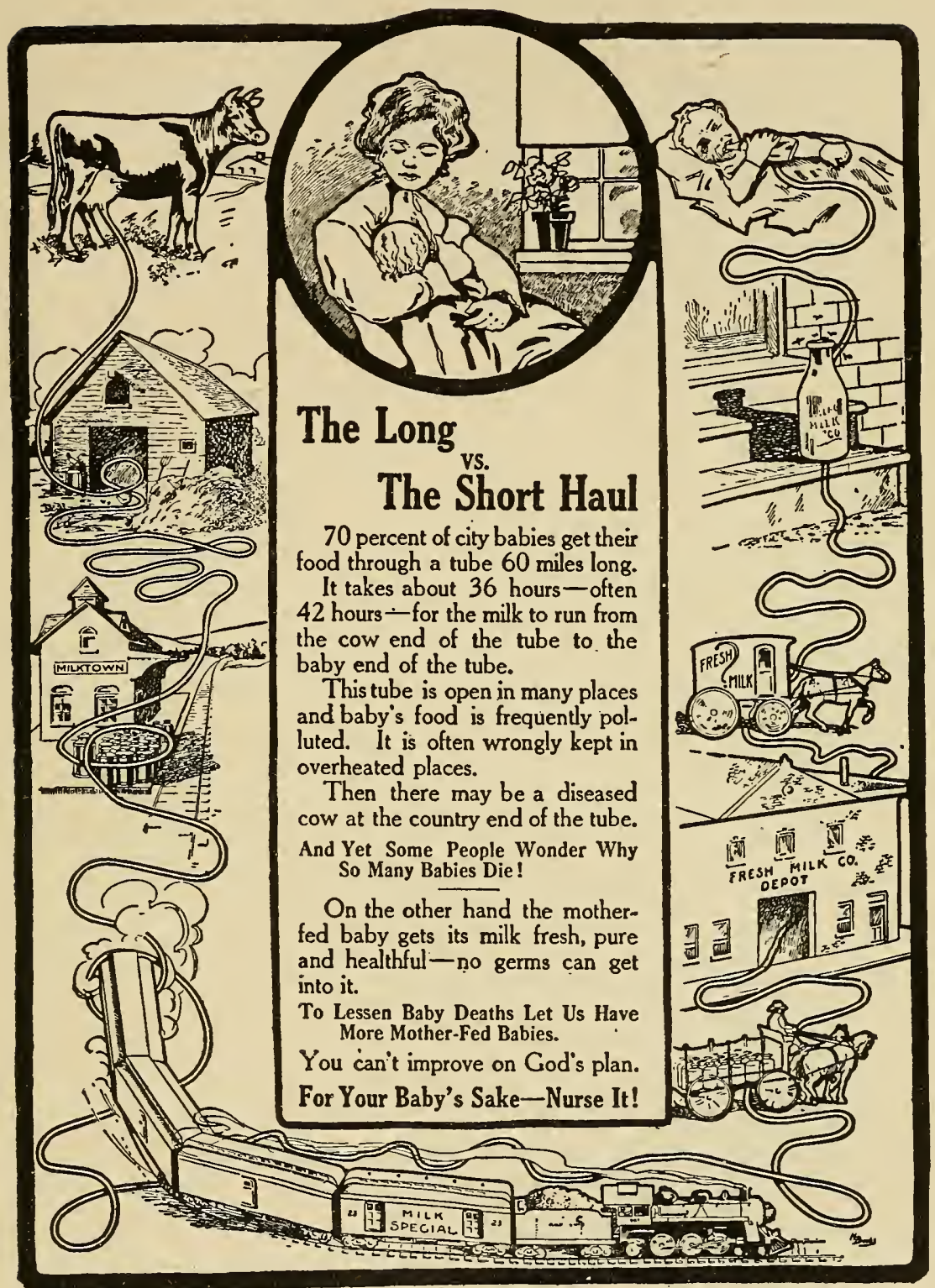

Fig. 3. The Long vs. The Short Hadl

This cartoon, from the Chicago Health Department, brings out the contrast between natural and artificial milk supply, and suggests some of the difficulties inherent in the latter. 
An important series of observations was made some years ago by Park and Holt, ${ }^{6}$ illustrating the effects of feeding infants with several different grades of milk. The deleterious results of bad milk during the summer months are shown by the following table, summarizing the observations on six groups of babies. (The percentages have been computed by the present writer from the original table.) *

\begin{tabular}{|c|c|c|c|c|c|}
\hline & $\begin{array}{l}\text { No. of } \\
\text { infants }\end{array}$ & $\begin{array}{l}\text { Did } \\
\text { well }\end{array}$ & $\begin{array}{c}\text { Did } \\
\text { fairly }\end{array}$ & $\begin{array}{c}\text { Did } \\
\text { badly }\end{array}$ & Died \\
\hline Store milk. & . . 79 & $27 \%$ & $29 \%$ & $25 \%$ & $19 \%$ \\
\hline Condensed milk. & 70 & 31 & 29 & 20 & 20 \\
\hline Good bottled milk. & 98 & 38 & 23 & 30 & 9 \\
\hline \multicolumn{6}{|c|}{ Milk from Central Distributing } \\
\hline Stations. & .145 & 58 & 23 & 16 & 3 \\
\hline Best bottled milk. . & 12 & 75 & 25 & - & - \\
\hline Breast feeding. . . . . & 31 & 55 & 22.5 & 22.5 & - \\
\hline
\end{tabular}

All cases excluding duplications 421

$44 \%$

$25 \%$

$21 \%$

$10 \%$

In the winter observations no appreciable difference among the different modes of feeding was noted; what might be considered good results were shown in 93 per cent of the cases as contrasted with the 69 per cent indicated by the above table.

* This study is open to criticism in certain respects. The small number of cases in the fifth group cannot be taken as a sufficient basis for rating best bottled milk above breast feeding. The number in the breast-fed group is also rather small for the calculation of significant percentages. Nor is distinction between raw and heated milk made in this table. The element of care of the infant (as well as other factors) in the different groups is discussed by the authors as a separate, important consideration taken into account in their conclusions, certain of which are quoted below. There is no doubt but that, were all other things equal, breast feeding would show decidedly the highest rating. The Park and Holt study, while not entirely satisfactory, is here quoted on account of its general illustrative character. 
Special observations were made on the effect of pasteurized as opposed to raw milk, as summarized in the following table:-

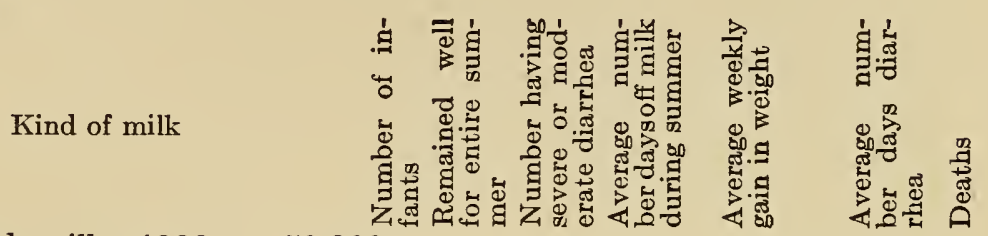

Pasteurized milk, 1000 to 50,000

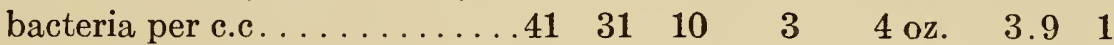

Raw milk, $1,200,000$ to $20,000,000$

bacteria per c.c..........51* $17 \quad 33 \quad 5.5 \quad 3.5$ oz. $11.5 \quad 2$

The results set forth in the first of the above tables cannot, indeed, be taken as indicating exactly the effects of the different kinds of milk, for the elements of care of the infant in the different groups was also of influence. The following extracts from the conclusions of the authors, who endeavored to sum up all factors, must, however, be taken as indicative:-

During hot weather when the resistance of the children was lowered, the kind of milk taken influenced both the amount of illness and the mortality; those who took condensed milk and cheap store milk did the worst, and those who received breast milk, pure bottled milk, and modified milk did the best. The effect of bacterial contamination was very marked when the milk was taken without previous heating; but, unless the contamination was very excessive, only slight when heating was employed shortly before feeding.

* Thirteen of the 51 infants on raw milk were transferred before the end of the trial to pasteurized milk because of serious illness. If these infants had been left on raw milk, it is believed by the writers that the comparative results would have been even more unfavorable to raw milk. 
When milk of average quality was fed sterilized * and raw, those infants who received milk previously heated did, on the average, much better in warm weather than those who received it raw. The difference was so quickly manifest and so marked that there could be no mistaking the meaning of the results. The bacterial content of the milk used in the test was somewhat less than in the average milk of the city.

The study just quoted, while not conclusive in all details, may be taken as roughly indicative of the effects of good and of bad milk, of raw and of pasteurized market milk, on infants. We need not go into the complex question of the mechanism of the effects of bad milk on the delicate infant organism. Specific germs may cause gastro-intestinal disorders and malnutrition in infants, and excessive numbers of germs of any kind are dangerous. The reason for the greater prevalence of such maladies and of the greater infant mortality during the summer months is: (1) That during that season milk is much more likely to be fermented, and (2) that warm weather lowers the vital resistance of the infant organism so as to induce gastrointestinal disturbances. While the latter of these factors may indeed be the more important, attention must be paid to both.

Such considerations as we have now viewed are substantiated in the experience of physicians and are reflected, though to an indeterminate extent, in the statistics of infant mortality already cited.

It would be desirable to know the exact weight of milk supply in infant hygiene,-a weight which undoubtedly has been exaggerated in some quarters.

* Heated to $165^{\circ} \mathrm{F}$. for 30 minutes. 
Large groups of deaths are caused by congenital diseases and diseases of early infancy, which are responsible for 35 per cent of the deaths under one year of age, and by respiratory diseases such as acute bronchitis, pneumonia, and broncho-pneumonia (15 per cent), as compared with diarrhea and enteritis ( 26 per cent), the group affected directly by milk supply. And in respect to all these groups the care given the infant in regard to methods of feeding, clothing, ventilation, avoidance of infection, etc., as well as the prenatal care of the mother and the quality of medical and midwife attention, are the preponderant factors. In the most general terms, the fundamental causes of infant mortality are recognized to be ignorance and poverty. In the infant welfare movement the general lines of attack are, therefore: first and chiefly, education of the mother, and, secondly, elimination of evils associated with poverty. Those who advocate milk control under the impression that it is the chief means of attacking infant mortality would do well to correct their judgment by considering also the other factors involved. ${ }^{7}$ Improvement of milk supplies does, however, take its place as an essential part of the general program, with the object of ensuring safe, wholesome milk for infant-feeding at a price within reach of the poor.

\section{MILK AS A VEHICLE OF DISEASE}

The readiness with which milk may become infected and transmit disease has already been mentioned. The following section, therefore, will be devoted to the briefest possible summary of the charges which epidemiology makes against raw milk. 


\section{Diseases Transmissible by Milk}

The following are the principal diseases transmissible by milk:

From human sources: typhoid fever, diphtheria, scarlet fever, septic sore throat (epidemic tonsillitis), tuberculosis.

From the cow: tuberculosis, septic sore throat, and other diseases of bovine origin.

(Milk-caused gastro-intestinal disease of infants was discussed in the last section.)

"Milk as a cause of epidemics of typhoid fever, scarlet fever, and diphtheria" is the title of a study made by Dr. John W. Trask of the United States Public Health Service, in which he collected and tabulated the summaries of 317 milk-borne epidemics of typhoid fever, 125 of scarlet fever, and 51 of diphtheria. ${ }^{8}$ This is the most extensive tabulation which has yet been made, but in addition to the instances recorded it is certain that many epidemics have gone unrecorded, while countless scattered cases of milk-borne infection must have escaped notice. Rosenau ${ }^{9}$ mentions how a single city, Boston, suffered from milk-borne epidemics in the space of four years, giving the following figures (greater Boston):-

1907 Diphtheria.................... 72 cases

1907 Scarlet fever................... 717

1908 Typhoid fever................... 400

1910 Scarlet fever. . . . . . . . . . . . . . . . . . . 842

1911 "Tonsillitis".................... 2,064 
The epidemic of "tonsillitis," or septic sore throat, put down in this table was notable not only on account of its extent but also because it was spread by raw milk derived from a supply subject to expert sanitary supervision. The disease has been brought into prominence through a number of epidemics in recent years. ${ }^{10}$ In some instances the infection has been ascribed to human sources, e. g., carriers of streptococci; in others it has been ascribed to udder inflammation in dairy cows.

The transmission of bovine tuberculosis to man through the medium of milk is now well recognized. The question of the amount of human tuberculosis of bovine origin has been the subject of much research, conspicuously by British and German commissions and the Research Laboratory of New York City. We can treat the subject but summarily here. Dr. William $\mathrm{H}$. Park has summed up the evidence and concludes that, in New York City (italics inserted):-

About 7 per cent of the infants and young children under 5 years of age dying from tuberculosis do so because of infection derived from infected milk or milk products. Fatal tuberculosis due to bovine bacilli is rare in those over 5 years of age, but, on the other hand, infection of the lymph nodes is frequent; 30 per cent or more of tubercular lymph nodes occurring in children between 5 and 16 are contracted through bovine bacilli. ${ }^{11}$

Applying Dr. Park's figure to the percentage of deaths from tuberculosis under five years of age in the Registration Area (approximately 7 per cent of the total tuberculosis) would indicate (omitting the rare 
deaths above five years of age) that about one-half of 1 per cent of all tuberculosis deaths are definitely due to the bovine type. Another authority, Ravenel, holds that there is a possibility of the bovine bacillus changing its type after becoming rooted in the human subject, which, if true, would mean that there is more tuberculosis of bovine origin than we can now prove.

While the above estimated mortality is not very great (amounting to about 500 deaths per year in the Registration Area) as compared with the mortalities from a number of other preventable diseases, it must be remembered that there is a much larger number of serious non-fatal cases and also that the amount of tuberculosis from this source may be greater than is now supposed.

In a summary of the researches, Rosenau ${ }^{12}$ states that "about one-quarter to one-half of all cases of tuberculosis in children under five years of age is associated with the bovine type," probably derived in all cases from cow's milk. The great bulk of the human tuberculosis bacteriologically identified as bovine is in the form of generalized, abdominal, and glandular tuberculosis of children. The percentages of mortality given by Rosenau for the age-groups "under 5," "5 to 14," and " 15 and over," when applied to the corresponding numbers of total tuberculosis deaths in the U. S. Registration area for 1913 in those age-groups, result in a total of 1925 deaths, or 2.1 per cent of all tuberculosis deaths, as due to the bovine type. This is considerably higher than the above estimate based on Park's figure. Rosenau ${ }^{13}$ himself says, "It is now 
estimated that perhaps seven per cent of the tuberculosis in man is of bovine origin." The basis of this estimate does not appear; in view of the others it looks very liberal.

Altogether, while it seems to be impossible to state at present the exact amount of human tuberculosis of bovine origin, it is to be concluded that tuberculous milk, though not the overwhelming menace it is sometimes thought to be, is a distinct factor in the milk problem.

Tubercle bacilli may be detected in market milk. Evidence from four typical American cities (Chicago, New York, Washington, Rochester, N. Y.), summed up by Rosenau, ${ }^{14}$ shows that out of a total of 551 samples examined the bacilli were found in 46 , or 8.3 per cent. This figure is doubtless an underestimate, for the laboratory methods may fail to detect the bacilli when present only in small numbers. At Rochester, N. Y., 12.65 per cent of milk samples taken from 185 retailers reacted to animal tests for tuberculosis. ${ }^{15}$ Unfortunately such tests give no indication of the numbers of tubercle bacilli in the samples.

Tuberculous cows infect the milk through tuberculous udders, but more largely through the manure, in which the bacilli are excreted in great numbers and which gains access to the milk at milking time. The infection is derived not only from obviously tuberculous cows but also from many which show no physical signs of the disease and whose condition can be determined only by the tuberculin test, to which further reference will be made in a later chapter. 


\section{SUMMARY}

We have seen that there are two general dangers to health in public milk supplies: (1) general bacterial contamination and (2) specific infection. Both of these are aggravated by modern conditions of city milk supply and even of the supplies of comparatively small towns, which may be derived and handled in a similar manner. Collection of milk from many separate farms, more handlings than ever before, and longer journeys favor greater bacterial contamination and alteration. The mixing of many milks to make up the larger supplies favors the spread of infection to hundreds of unsuspecting consumers.

Milk-borne disease is indicted by Dr. Charles E. North as follows, under the title, "Why milk should be pasteurized":-16

A. Raw Milk Causes Infant Deaths.

Twenty-five per cent of all deaths are of children under five years of age.

More children die from intestinal disease than from other causes. Children's food is chiefly milk.

Dirt bacteria, harmless to adults, irritate and inflame the intestines of children.

B. Raw Milk Causes Septic Sore Throat.

Septic sore throat is a violent form of tonsillitis.

It is often followed by acute articular rheumatism, erysipelas, peritonitis, endocarditis and other serious inflammations.

Boston, Mass.

Boston, Mass.

Chicago, Ill.

Baltimore, $\mathrm{Md}$.

Cortland-Homer, N. Y. 669
1,043 cases from one raw milk supply

227

10,000

602

" "

" " " "

" " " " "

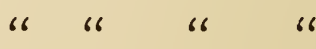

16 16 1606 
The disease attacks adults chiefly. There are often deaths.

Bacteria in sore udders of cows closely resémble bacteria found in these sore throats.

\section{Raw Milk Causes Typhoid Fever.}

Trask has collected records of 317 outbreaks of typhoid traced to raw milk. Here are a few :-

Glasgow, Scotland Cologne, Germany Port Jervis, N. Y. Springfield, Mass. Oakland, Cal. Montclair, N. J. Stamford, Conn.

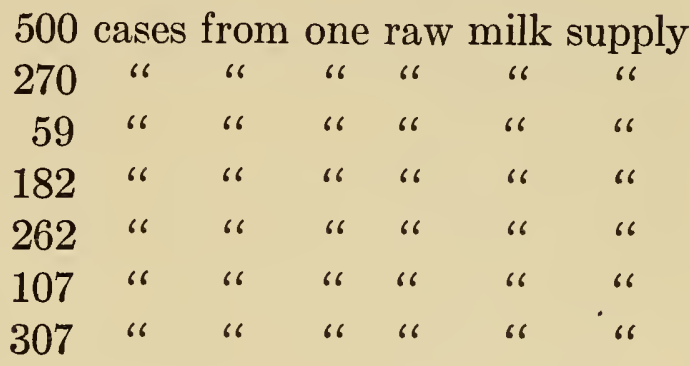

D. Raw Milk Causes Tuberculosis.

One hundred and ninety-one tuberculous cows were taken out of the most celebrated certified dairy herd of 632 animals in November, 1914. In December, 72 tuberculous cows were found in a herd of 86 in a model dairy where every expense and precaution had been taken.

Tuberculosis is very common and the majority of dairy herds contain tuberculous cows.

Authorities estimate that 75 to 90 per cent of human beings have tuberculosis at some time during their lives. Most of this is human, but some of it is bovine.

Tabulation by Park and Krumwiede of 1038 cases of tuberculosis showed the following:-

Cases Bovine Percent

Adults over 16 years.......... $686 \quad 9$

Children 5 to 16 years.......... $132 \quad 33 \quad 25$

Children under 5 years. . . . . . . $220 \quad 59 \quad 27$

Total. . . . . . . . . . . . 1,038 101 
E. Raw Milk Causes Scarlet Fever and Diphtheria.

One hundred and twenty-five epidemics of scarlet fever due to milk have been collected by Trask. A few examples are as follows :-

\section{Scarlet Fever}

Buffalo, N. Y.

57 cases from one raw milk supply Washington, D. C.

London, England

Beverly, Mass.

Liverpool, England Mt. Vernon, N. Y. Boston, Mass.

$\begin{array}{rllllll}33 & 66 & 66 & 66 & 66 & 66 & 66 \\ 284 & 66 & 66 & 66 & 66 & 66 & 66 \\ 6 & 66 & 66 & 66 & 66 & 66 & 66 \\ 59 & 66 & 66 & 66 & 66 & 66 & 66 \\ 45 & 66 & 66 & 66 & 66 & 66 & 66 \\ 195 & 66 & 66 & 66 & 66 & 66 & 66\end{array}$

Diphtheria

Fifty-one ep:demics collected by Trask. A few to illustrate:-

Brookline, Mass.

Los Angeles, Cal.

Wellsville, N. Y.

Clifton, Ohio

Hyde Park, Mass.

Warwick, R. I.
12 cases from one raw milk supply

35

84 " 6 " 6 " 6 6

36 " 6 " " 6

69 " 6 " 6

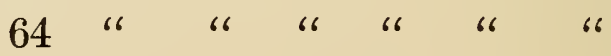

It would be interesting to know exactly what relative part is played by milk in the transmission of communicable diseases. Exaggerated statements are made by well-meaning but uninformed persons, and the impression is sometimes given that milk is little if at all short of a poison. This is deplorable, for the truth is that milk is, on the whole, an exceedingly valuable food even though, under wrong conditions, a source of danger. Exactly how great this danger is, as com- 
pared with that from other possible sources of disease, is a question which the data of sanitary science are not as yet sufficient to answer. For present practical purposes we may say, in the words of an investigator who has made a noteworthy examination of the evidence on the question, ${ }^{17}$ that " the accumulated evidence of scores upon scores of definitely demonstrated milkborne epidemics is enough to show that raw. market milk is always a risky food."

\section{A Practical Definition of "Pure Milk"}

To sum up the whole matter, we wish milk which is:

1. Free from infection of human or animal source.

2. Free from dirt, filth, and other foreign matter.

3. Free from deleterious bacterial contamination or development.

4. Free from adulteration and of known food value.

Such milk may, in a practical sense, be termed "pure."

These requirements may further be summed up in the three words: safety, decency, nutrition.

Taking safety and decency as the objects of sanitation per se, we shall find that if we secure milk which meets the requirement of decency, or cleanliness, in the highest degree, we have gone a long way toward obtaining also safety. But experience shows that the two conditions are by no means synonymous and that if safety is to be entirely ensured the product must be subjected to a precautionary process-such as pasteurization-before using. Neither a clean milk which is still somewhat unsafe nor a safe (pasteurized) milk which is unclean meets the requirements. 


\section{THE MODERN MILK PROBLEM}

So much for the general sanitary desiderata. In succeeding chapters will be considered the means of attaining them and the practical difficulties and personal factors which frequently complicate their attainment. 


\section{CHAPTER II}

\section{THE CASE TO-DAY}

\section{THE CRY FOR "PURE MILK"}

Publicity on such facts as have been outlined in the last chapter has resulted in a general demand for "pure milk,"-a demand associated in the public mind with the general movement for "pure food." A language of milk "horrifics" has been developed, based at one end on more or less exaggerated fact and on the other on the fear emotion of the public. Sanitary reformers, enterprising health officials, lecturers, and writers have vied with each other in vivid picturing of the menaces of impure milk. Bacteria in milk have been branded as the "invisible murderers" that produce the "slaughter of the innocents." Newspapers eager for popular sensation have been quick to see the publicity value of all this and have given it columns of space. Some have even conducted inspection campaigns of their own, professing their inability completely to tell the "unbelievable truth of the unsanitary conditions which have been existing." As the result of their efforts they have announced the "cleaning of the Augean stables in a day," and have then turned the matter over to be dealt with by the "angered authorities."

The following utterances quoted in a recent newspaper account of a milk inspectors' meeting, headed 
"Mr. Milk Supply is worse than Mr. Barleycorn," are fair examples of the harrowing type:-*

Fifty per cent of the milk that goes to the creamery for pasteurization is filthy, utterly unfit for food.

The farmer is hopeless-dirty, mostly ignorant, careless. Because he can't get enough for his milk he won't give good milk.

We have found to our dismay that dealers on whom we have been depending have been permitting large numbers of diseased cattle in their herds.

We can't get the right kind of legislation.

The politicians are playing a political game with the farmers. We've got to depend on our own efforts.

There are only two grades of milk-good milk and bad milk. The rest are simply grades of dirt.

Such utterances have awakened public attention, but they have had at the same time an undesirable effect on the minds of some persons. Just as publicity regarding tuberculosis has had as a by-product an undue dread of consumptives, so has the "pure milk" campaign made some people fearful of milk as such. This has been perhaps an unavoidable incident of forceful publicity, but it is an unfortunate one now calling for correction.

* The language and literature of exposure are not a new development. A notable example dates back to Smollett's description, in the novel "Humphrey Clinker," of the milk supply of eighteenth-century London:- "I need not dwell on the pallid contaminated mush which they call strawberries, soiled and tossed by greasy paws through twenty baskets crusted with dirt, and then presented with the worst milk, thickened with the worst flour, into a bad likeness of cream; but the milk itself should not pass unanalyzed, the produce of faded cabbage leaves and sour draff, lowered with hot water, frothed with bruised snails, carried through the streets in open pails, exposed to foul rinsings 
Dairies, recognizing the state of the public mind, have taken to advertising, with the catch-phrase "pure milk." Letters are written in the newspapers demanding it. Legislators introduce "pure milk bills" designed to conciliate the consumer without arousing the farmer. Civic organizations make it a major issue, the subject of campaigns. Investigations are constantly under way and "solutions of the problem" are galore. Political platforms contain "pure milk" planks so guardedly worded as to conciliate all parties concerned. Health authorities long ago promised that "the consumer should be educated to the value of clean milk." And now agricultural authorities, awaking to their responsibilities, announce that "dairymen must be educated to the value of clean milk." And farmers hold indignation meetings to protest that they never intended to produce anything but pure milk and that they have a natural right to be let alone by theorists. Everybody is trying to educate somebody else. "Pure Milk" is a phrase to conjure with.

\section{Can Pure Milk be Got?}

Much of this agitation is unaccompanied by clear understanding of the facts. A recent public health discharged from doors and windows, spittle, snot, and tobacco quids from foot-passengers, overflowings from mud-carts, spatterings from coach-wheels, dirt and trash chucked into it by roguish boys for the joke's sake, the spewings of infants, who have slabbered in the tin measure, which is thrown back in that condition among the milk, for the benefit of the next customer; and, finally, the vermin that drops from the rags of the nasty drab that vends this precious mixture, under the respectable denomination of milkmaid." Fortunately it takes much less than such a description to shock the more sensitive, better-informed modern milk-consumer! 
bulletin concludes a discussion of milk supply with the words, "The choice is easy. Insist upon clean, pure milk." Everyone familiar with the subject has heard or read that sentiment hundreds of times. The phrase "pure milk" suggests its opposite, "impure milk," and it is a common popular idea derived from these terms that there are two clearly distinct kinds of milk, good milk and bad milk. Many people doubtless believe that an inspector can thrust a tester into a can of milk and decide instantly in which category it belongs. The usual demand for "pure milk" is a demand for the best milk, and the notion is that one such best can be both defined and universally obtained. "The chief good to be accomplished at the outset," writes a newspaper in comment upon a milk campaign, "will be the arousing of public sentiment against anything but the purest milk."

The trouble with this is that it requires an absolute ideal incompatible with practical conditions. Bacteria in milk are impurities, but it should be recognized that a certain bacterial content must practically be permitted according to the purpose for which the product is to be used. Again, there are varying natural degrees of nutritional value, and science has not determined exactly what is the most nutritive milk.

The air would be cleared if we spoke of milks, thus emphasizing their differing characters. The scientific object is to gauge the qualities of milk of different characters and reduce them to categories. When this is done it is seen that instead of speaking of one absolute kind of pure milk, it is logical to define what shall be considered a "pure milk" for infants, or for 
adults, or for cooking and manufacturing purposes, and then to endeavor to get the best possible milk for each purpose.

To give an answer to the question, "Can pure milk be got?" it may be said that to raise all milk to the highest quality is impracticable, but to obtain a safe, suitable milk for each purpose is entirely possible. And this should be the immediate object of practical milk sanitation.

\section{THE MODERN MILK PROBLEM}

The present-day problem of milk supplies is rooted in an obvious condition of modern urban civilizationthe wide separation of the producer and the consumer. It is also true, no doubt, that the conditions of urban life have made city babies and children, and city dwellers in general, more susceptible to the effects of bad or infected milk. But it is the long haul and the broken journey that are chiefly responsible for typically modern conditions. To illustrate roughly why the milk question has come to the fore in recent years with such insistence, we need only point to two contrasted pictures-the old-time milk supply and that of the present day in our cities.

\section{The Old-Style Milkman: An Anachronism To-day}

The old-time milkman kept his cows just as he would keep any other live stock. He went about his milking in the rough, untutored manner that he would go about any other farm work, without stopping to wash the dirt of honest toil from his hands, or to clean the caked manure from the udders of his cows. The 
family kitchen was the milk-house where cans were washed. He drove into the nearby town and with a dipper ladled out his product into whatever pans or pitchers were presented to receive it. There were sanitary objections to these methods, but few or no sanitarians to point them out.

The consumer found no serious fault with any milkman but the one who eked out his supply by means of the pump.

Even to-day. the old-style milkman survives, and many small towns and some large ones receive their supplies in some such manner as the above. In fact, he has by no means disappeared, but has simply become absorbed in the modern milk mechanism.

\section{The Modern Milk Mechanism}

With the growth of towns and the reaching-out into the country for milk supplies from comparatively distant and unknown sources, the old evils were exaggerated and new ones added. Whatever check existed in the knowledge of the consumer of his source of supply disappeared. The element of time, with the danger of stale or decomposed milk, became important. The product passed through the hands of a new class of men, the dealers or middlemen, who perhaps scarcely ever see a dairy farm. The railroad was called into requisition, introducing a new difficulty. Quantities. of milk were mixed for shipment by wholesalers, thus making possible the infection of large supplies by a few quarts. The city milk plant, with its frequent lack of sanitation, came into existence. And now, at the present time, the old-fashioned methods of milk 

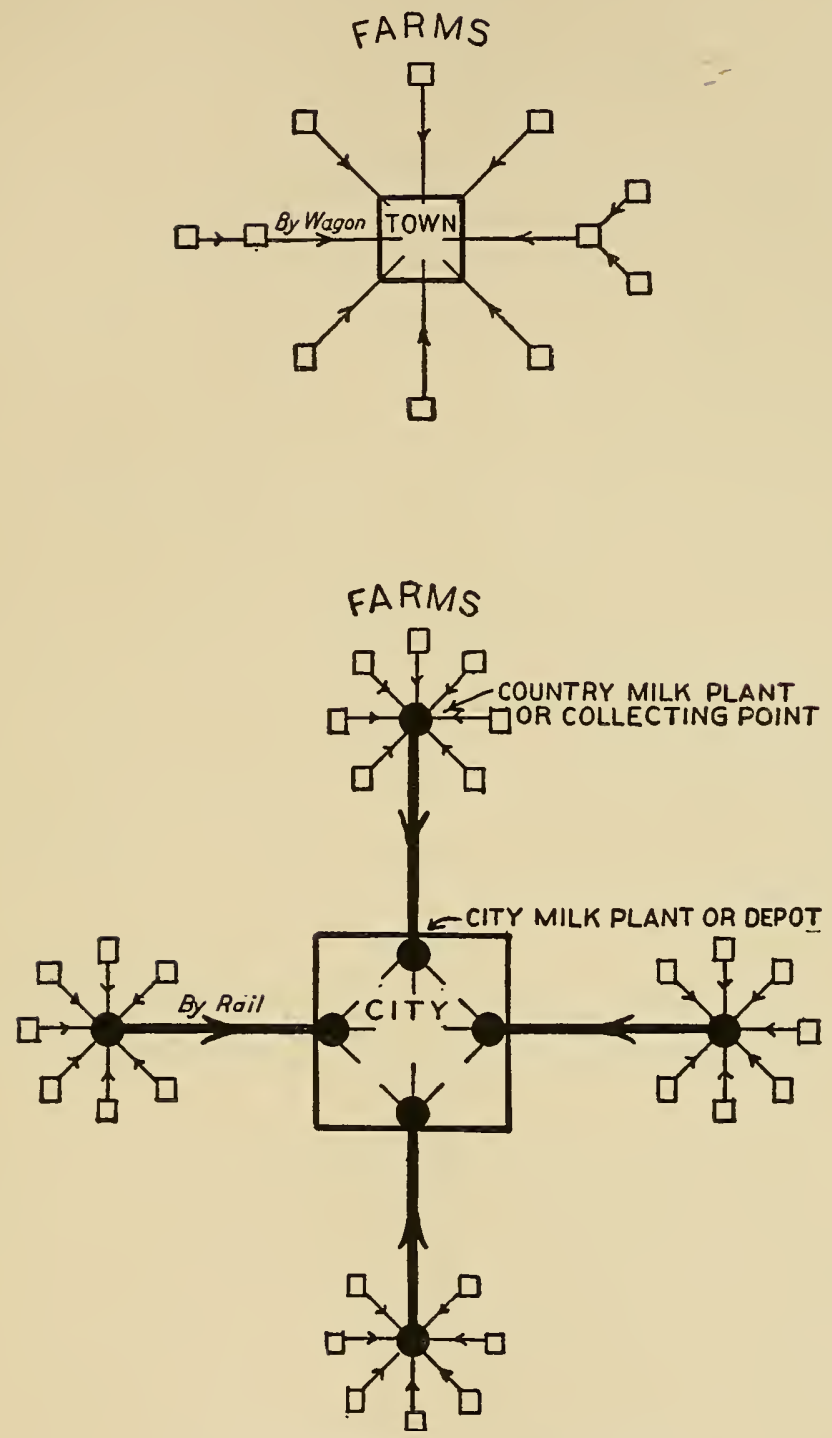

Fig. 4. Systems of Milk Supply

Upper figure: simple or undeveloped state, small communities. Each dairyman retails his own supply, sometimes drawing from his neighbors. Lower figure: developed state, under city conditions. Milk depots for centralizing such operations as collection, pasteurizing, bottling, and transferring milk by wholesale are in this case an economic necessity. In many communities a mixture of the two systems exists. 
production prevail to a large extent, with the modern disadvantages and dangers added to them.

In this final form of milk supply the producer may have no idea whatever of the final destination of his milk; and the consumer, as a rule, neither knows nor cares where the milk which he buys comes from. The personal relation between consumer and producer is totally lost, and the middleman comes to hold the position of principal importance, as the only person in touch with all. These circumstances, and the very size of the system, tend to make it largely mechanical, and all connected with it merely subordinate parts in a great machine which, for good or ill, must work on incessantly. . . . Under this system the milk is often two days old . . . before it is actually consumed. It also necessarily passes through many hands en route, and is therefore accessible to manipulation, adulteration and contamination. ${ }^{1}$

The following picture, given by Rosenau, sketches verbally the situation shown graphically in Fig. 3:

Milk when it reaches the consumer in the city is often very different when compared to the same milk used on the farm. The farmer cannot understand why it is that the milk agrees with his baby, but makes the city baby sick. He forgets that the milk he sends to the city is often placed in dirty cans, perhaps rinsed with infected water or mopped "clean" with soiled cloths. The cans are often placed on the farm wagon and carted several miles to the nearest railroad station, where they stand some time in the sun and occasionally are exposed to dust, flies, and prying fingers of irresponsible persons. After this they are loaded on the milk car, which is perhaps warm. Arriving in the city, the cans again stand around the milk platform waiting for the city wagon, when 


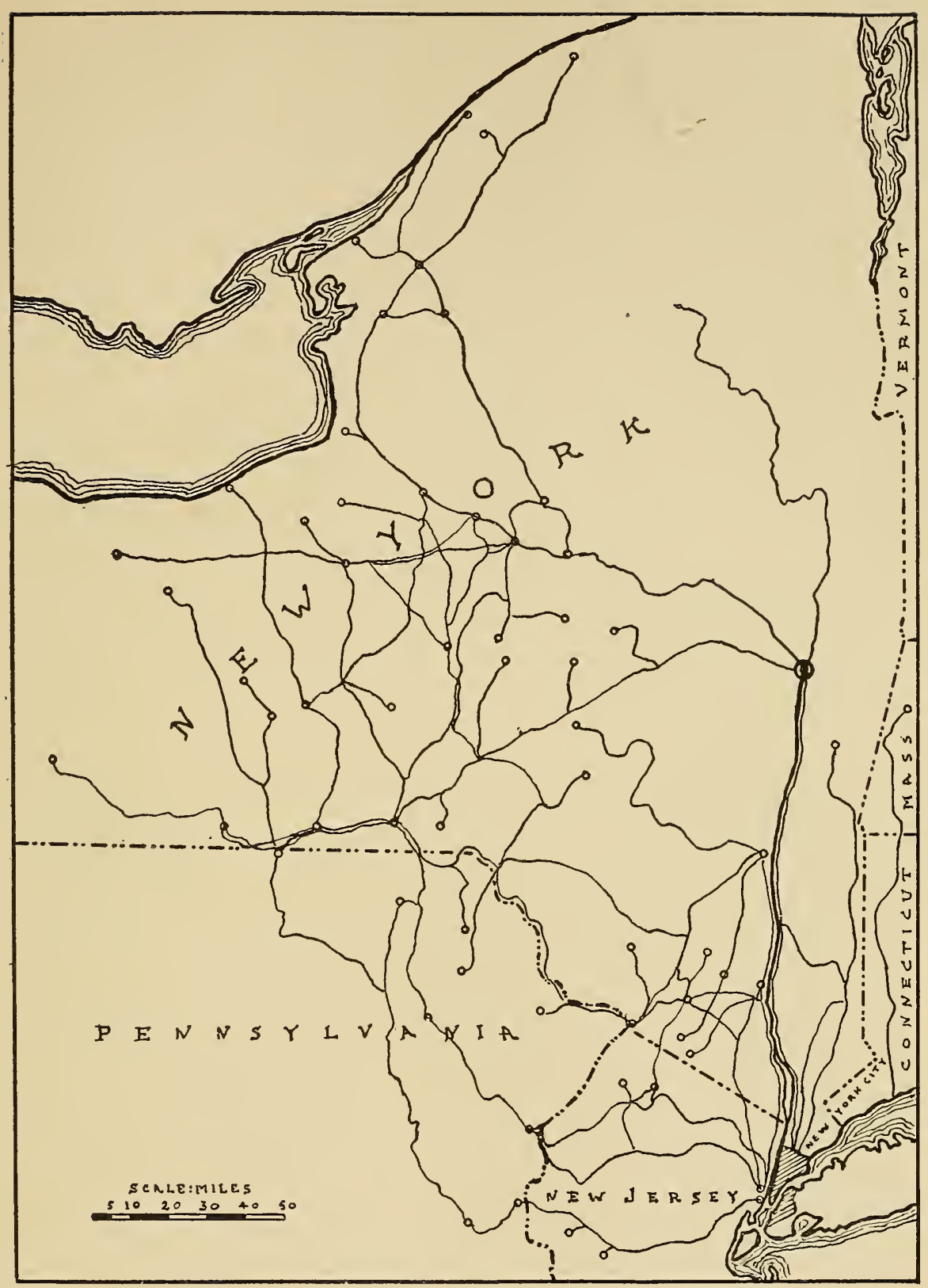

Fig. 5. Typical "Milksheds" of Large Cities

(a) New York (1905). (This and the next four maps are derived from Bulletins 81 and 138 of the Bureau of Animal Industry, U. S. Dept. of Agriculture. Since the investigations were made the milk octopus has in each case reached out still farther.) 
they are carted to the city dairy. Here they are opened, the milk is tasted and smelled, and poured into a large vat, where the contents of the can is mixed with the milk from numerous other cans. From this vat the milk is pumped to a clarifier, where much of the dirt and slime is removed. From there it may pass through other processes before it is cooled and bottled. The bottle may not have been properly cleansed and sterilized. This bottle is placed upon a wagon and carried to the householder, who thus receives milk that is several days old, has been frequently handled, has come in contact with a number of different containers and machines, and has had a good chance to deteriorate as well as to collect various kinds of dirt, with the possibility of picking up infection. City milk, stale, dirty, and bacteria-laden, is therefore a very different article from the fresh country brand. $^{2}$

Fortunately the worst of these features do not always prevail. There are special milks, such as certified milk, which are produced and handled with a high degree of precaution. There are dealers who take every care asked of them, and there are milk concerns which have their own inspection and testing systems and operate plants which are sanitary in every particular. But we are here discussing the general situation, and the former picture must be taken as typical of a great deal of city milk.

This problem of urban milk supplies is not new, but it is constantly growing. It has been growing in years past and will continue to grow with the increasing urbanization of our population.* It is, primarily, a mat-

* As an extreme example of the condition toward which urbanization tends, one may take New York City, which receives very little milk 


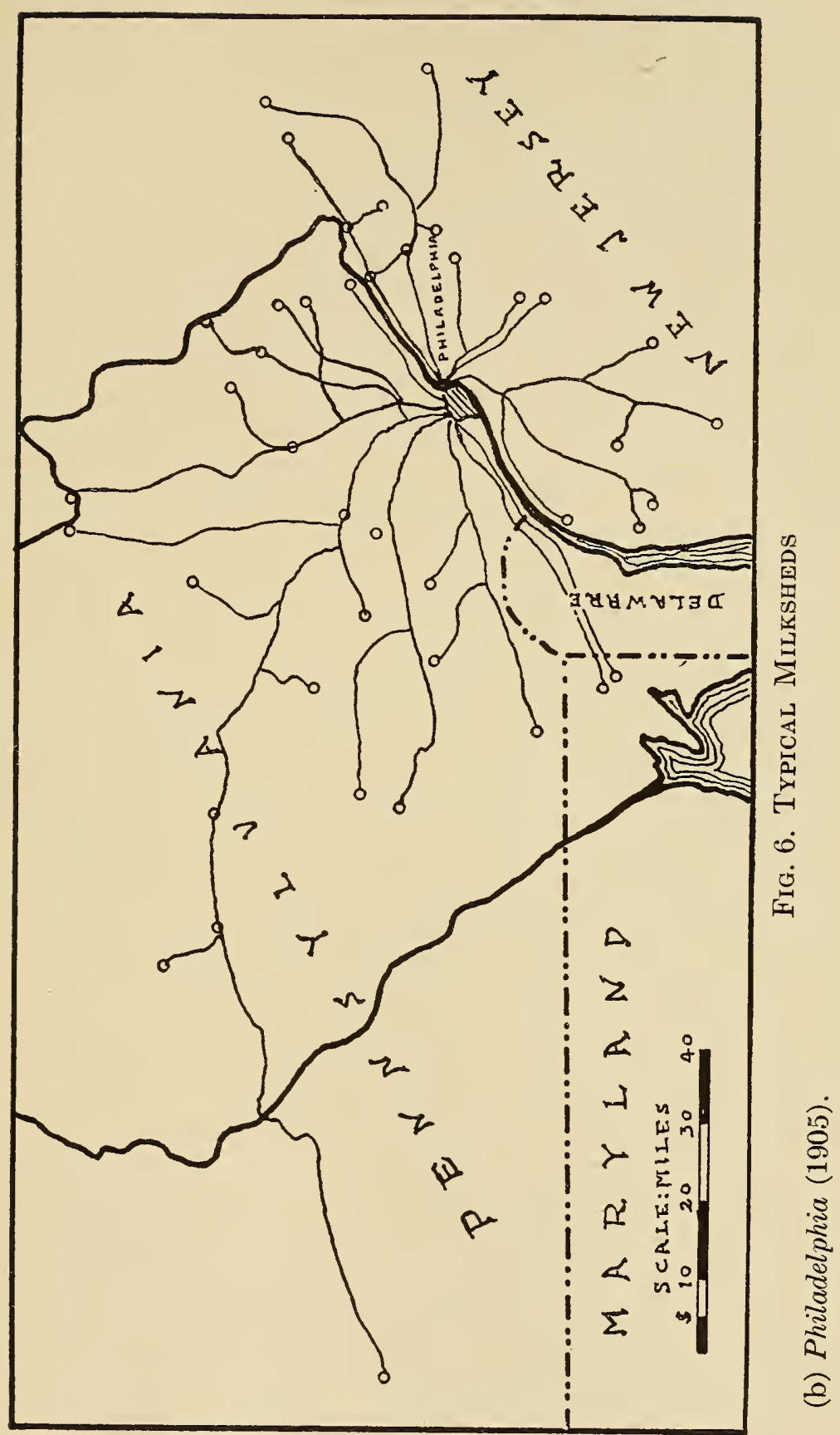


ter of the larger centers of population, yet so far is the urban social structure characteristic even of the smaller centers that they may have a similar problem. It not infrequently happens, for example, that a suburb or a town situated near a large city has milk supplies which come from that center and are originally drawn from some distant region; or such supplies may be dropped off from a main artery of railroad traffic. It is not, therefore, entirely a question of the size of the community, but of local conditions. Even towns where the supply is derived from near by have their difficulties in obtaining satisfactory milk supplies.

\section{THE PARTIES IN THE CASE}

The human factor looms large in the milk question. Aside from the sanitary and economic factors involved, efforts at a just and harmonious solution have to contend with the different, and too often conflicting, interests of several distinct classes of men. Controversy has been aggravated and prolonged by ignorance of underlying facts, by distrust among the parties in the case, and by natural refusal to concede points not clearly proved. We shall sketch here the general grounds of these different standpoints.

from within fifty miles of the city, its daily supply of $2,500,000$ quarts being derived from 44,000 farms located in six different States (1912). Boston gets most of its supply from outside of a fifty-mile radius, drawing from six States and Canada. Chicago presents a somewhat different picture, most of its supply coming from comparatively near by, but in this case there are many separate sources of supply and complexity of milk routes. Such conditions, though cited from the largest cities, are illustrative of general tendencies under urban and even under suburban conditions. 


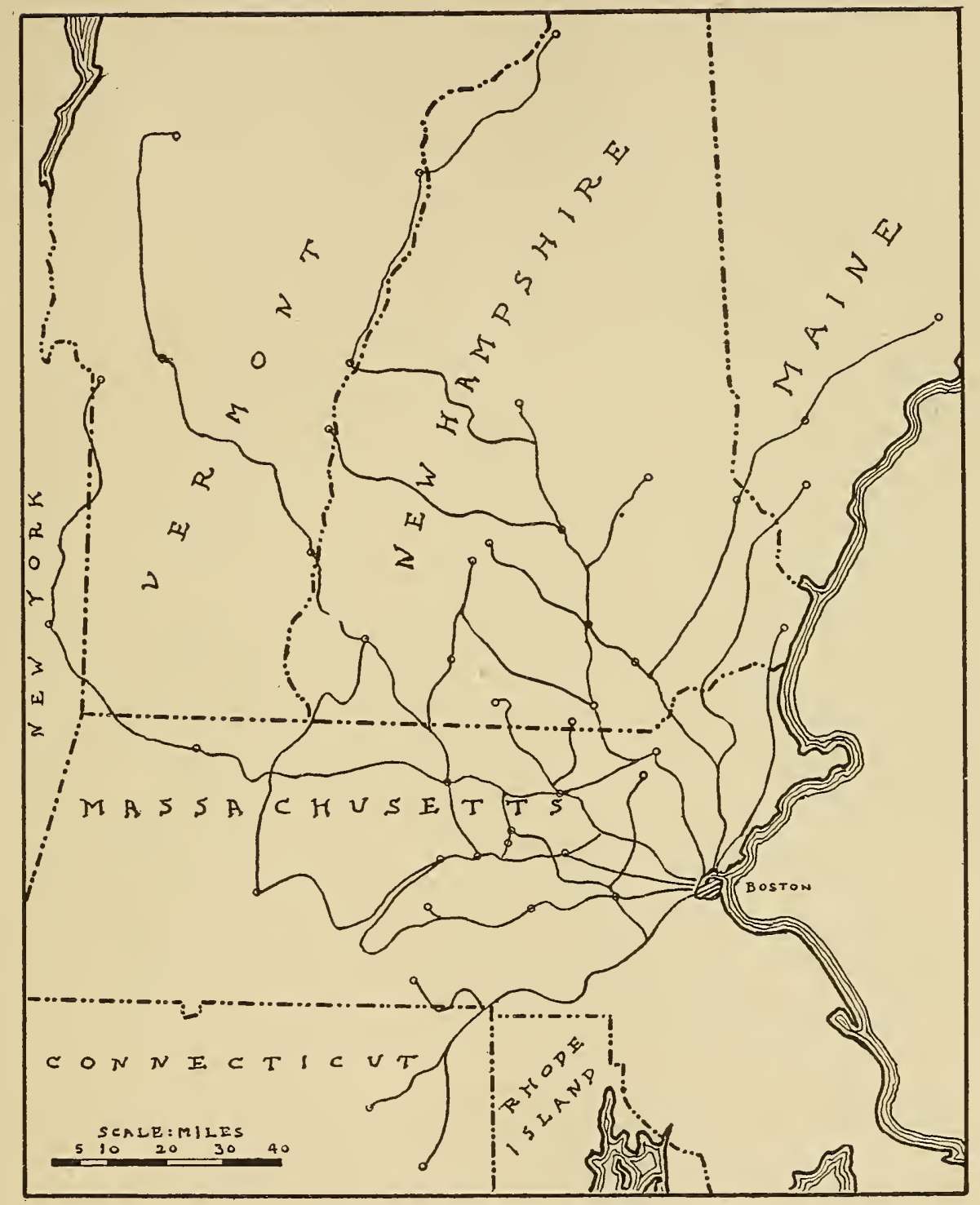

Fig. 7. Typical Milksheds

(c) Boston (1905). 


\section{THE DEMANDS OF THE HEALTH OFFICIAL}

The sanitarian and the health officer have naturally taken the leading part in the milk debate. On the whole they have had a fair hearing and there has been an inclination to heed their counsel when this was strong

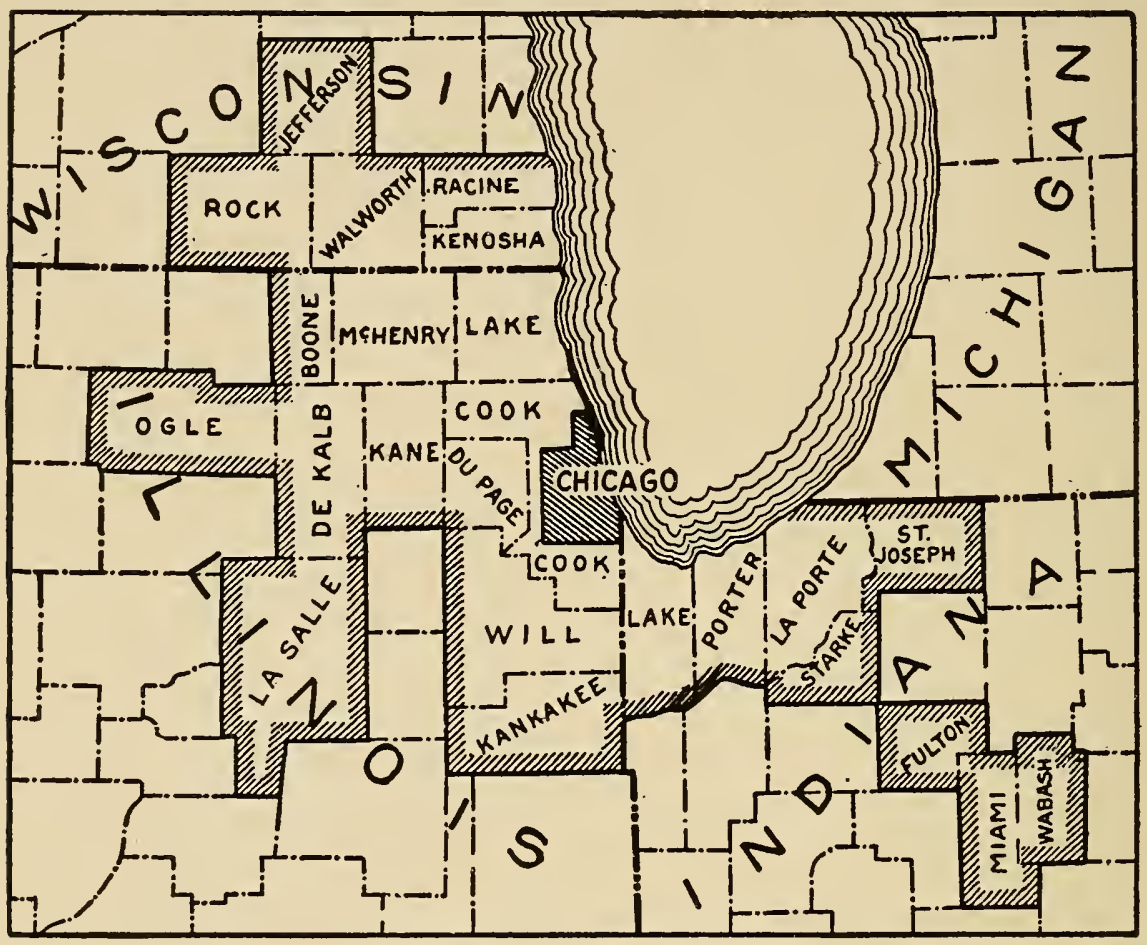

Fig. 8. Typical Milksheds

(d) Chicago (1911).

and definite. They have, however, labored under the disadvantage of having to deal with a matter involving difficulties if not complications and one apt to be overshadowed by other public health problems. They have sometimes framed verbose or impossible regulations. They have often failed to impress the dairyman by meeting his practical objections. As one writer says:- 
The position of the boards of health has been difficult, for they have been charged by the farmers with ignorance of farm conditions, by the railroads with imposing impossible

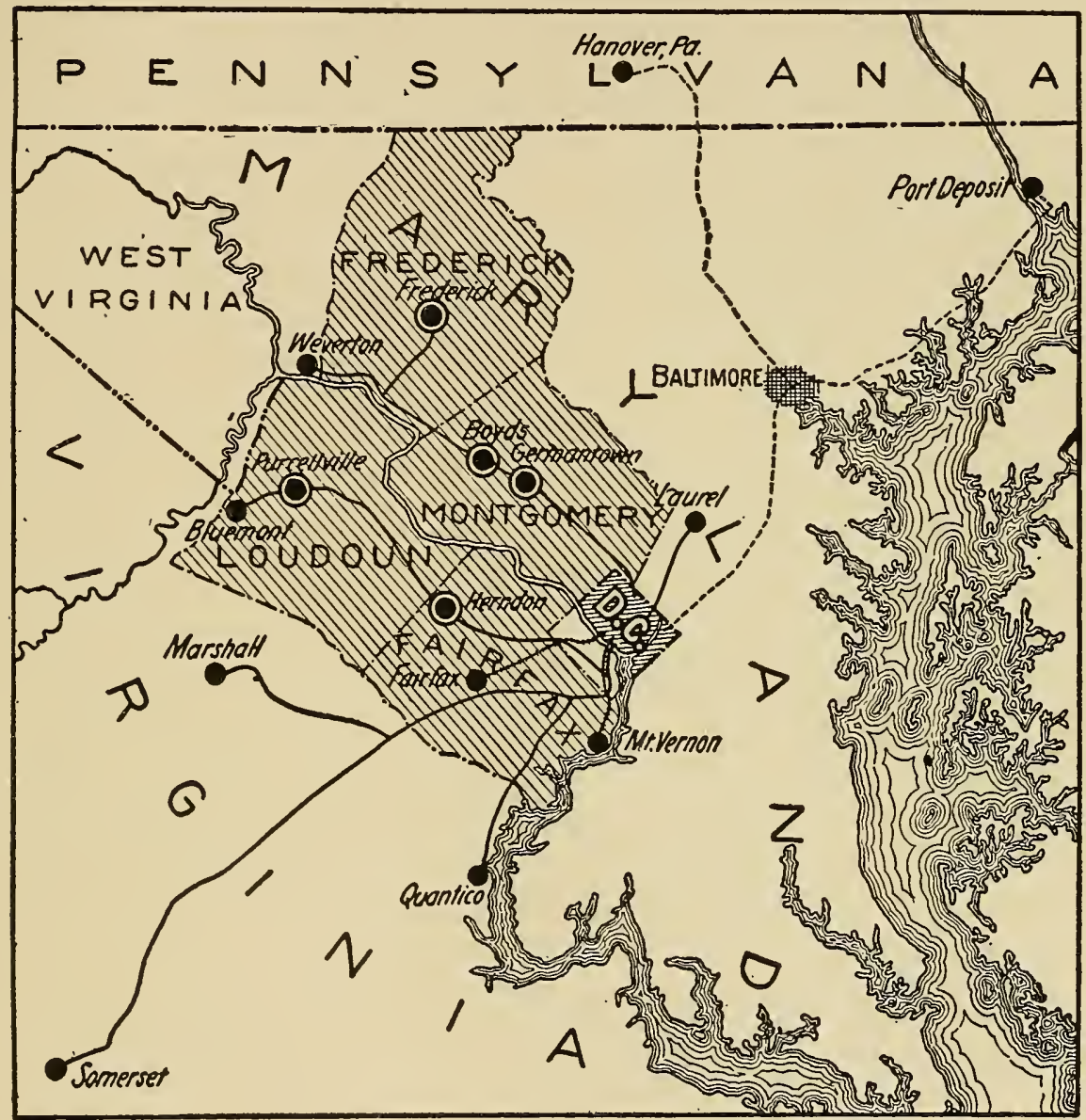

Fig. 9. Typical Milksheds

(e) Washington (1911). Heavy dots show points from which milk cars start, largest shipping points enclosed by circles.

orders as regards icing and other matters, and by contractors with the promulgation of regulations that were unnecessary, arduous and expensive. ${ }^{3}$

The active health officer or milk inspector must expect more or less objection and misconception from 
those whom his activities affect. He must, therefore, be prepared to deal with difficulties and justify his course.

\section{THE PRESSURE ON THE FARMER}

It is from the producer, the dairy farmer, whether he retails his product himself or sells to a middleman, that the loudest opposition to higher sanitary requirements has come. His most frequent protestation relates to the price that he receives,-namely, that he cannot make sanitary improvements which necessitate greater expense and care without some increase in that price. He argues that his labor is becoming harder, his expenses heavier, and his margin of profit (if, indeed, it exists) smaller, while time-honored ways are being replaced by "new-fangled notions" which bring him no benefit. "The complaint is," as an agricultural journal remarked not long ago, "that everything used in the production of milk has increased in cost during recent years, while the price of milk has remained practically the same or [is] in some cases even less."

In corroboration of this protest of the farmer a milk specialist of the United States Department of Agriculture writes:-

If the dairy farmers of this country were asked this question, "What can be done to encourage the production of clean milk?" I am sure that nearly all would answer, "Secure better prices and markets for our product." Therefore, the conditions as they exist to-day are these: many dairymen do not receive enough for their product to warrant any extensive changes or outlay, and many dairymen who 


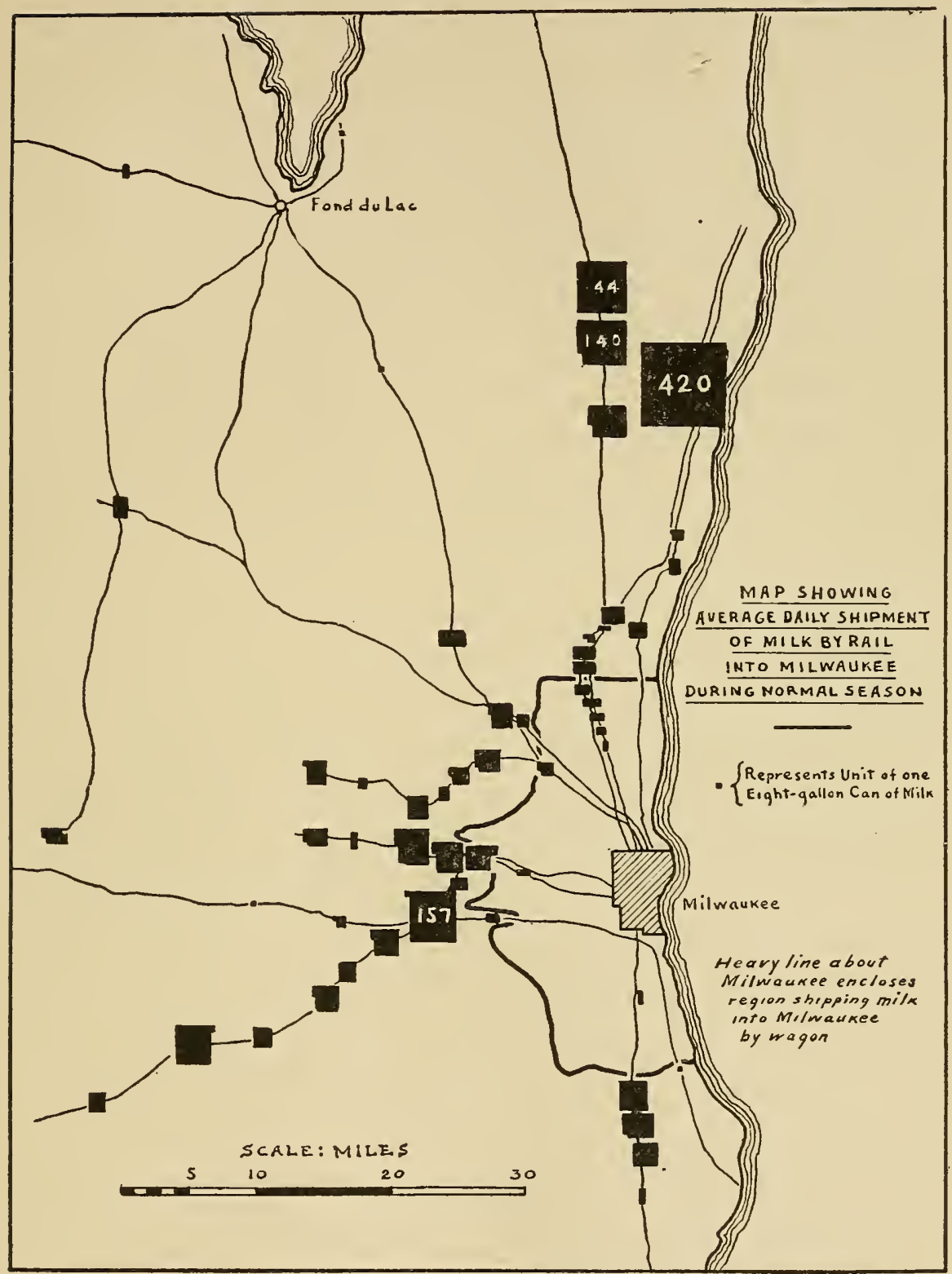

Fig. 10. Typical Milksheds

(f) Milwaukee (1911). This chart represents only milk shipped by rail; about as much again is brought in by wagon. (Bulletin 13, Milwaukee Bureau of Efficiency and Economy, 1912.) 
are paying no particular attention to better milk are receiving the same price for their milk as those who are trying to market a clean, safe product. This state of affairs, one can readily see, does not encourage clean milk production; however, we must work with the facts as they are. If we expect the farmers to produce better milk, we must assist them to receive a reasonable profit for their labor.

In some sections of the country, dairymen state that the price received for milk is not sufficient to warrant their staying in the business. If it were not for the value the cows are to the farm, more dairymen would stop milking them, and take up some other line of agriculture. The question of prices and profit is a problem which we must meet. . . 4

Undoubtedly the economic pressure upon the dairy farmer is heavy, but the question how far his complaint on this score is justified and what the remedy is must be left for consideration in a later chapter.

A contributing cause to the farmer's disquietude is his frequent ignorance and distrust of bacteriology and sanitary science. The ultraconservative farmer is apt to consider measures of milk sanitation as mere theory, as hobbies of the doctor or fads of the health officer. We cannot, of course, expect farmers to be versed in sanitary bacteriology, but we can expect them to so appreciate its aims as to act intelligently for the attainment of these.

The farmer often bespeaks consideration of the hardships that beset his mode of life, with the plea that no further demands should be made upon him without corresponding additional compensation. Here is a typical example, taken from the letter of a dairyman to a Massachusetts newspaper:- 
Look at his [the milkman's] duties. Up in the morning around two o'clock three hundred and sixty-five days in the year; hustling to get the milk to his customers. He finally arrives home at eleven o'clock. Then comes the washing and sterilizing of bottles, cans, and utensils used. Then a late dinner, the teams to care for, the surrounding country gone over to collect the milk for next day. By the time it is all in, bottled, and iced for next morning's trade, it is perhaps nine o'clock. Hurry to bed, for two o'clock soon arrives, rain or shine. It has to go; no holidays or Sundays here. Where is the new cow coming from to take the place of the old one when she is gone? The blacksmith had a much larger bill the past six months; the milkmen are robbing the good people of — by asking them six cents a quart for milk when they should get ten cents, its value.

Why are so many dairy farmers going out of business, five in our neighborhood in the past two years? A sixth one goes next month, myself. At a cent a quart increase in wholesale price over four years ago I cannot make both ends meet in the milk business at the present cost of production. You people who think you are being imposed on better go dairy farming a while.

The kind of complaint of which this is representative, whether coming from the farmer-retailer or the farmer who sells to a middleman dealer, cannot be dismissed without consideration. Its economic basis will be examined in a later chapter. That it denotes the attitude of many farmers, an attitude which must be taken into account in any practical examination of the milk question, is the point for present marking. Altogether, the disadvantages of the farmer are many, and his pleas demand the attention of reasonable men. "The dairyman," as one of them puts it, "is trying to 
make a decent living in a legitimate way, is not trying to poison anybody, and does not like to be forced out of business nor to sell out to a trust. He does not want to raise the price of milk, and will only do so when forced to." If he is averse to altering his methods, tradition and lack of information are largely to blame.

The case is well put by Rosenau:-

The attitude of the farmer is often unfortunate, but he cannot be blamed for getting out of patience with the subject. He is made the butt of the cartoonists and is hammered at from all sides. He is inspected and reinspected, preached to, lectured at, scolded, and the object of legal action. He is pestered with the enthusiast, the reformer, the sanitarian, the lawyer, the baby's mother, and the baby's doctor. He is showered with advice, some of it contradictory. In this predicament he does not know which way to turn. If the attitude of the farmer is often unfortunate, the attitude towards the farmer is frequently equally unfortunate. Too often he is regarded as a back number, unprogressive, incompetent, and even dishonest. As a class no finer stock is to be found in the world than the sons of the soil. The city replenishes its, worn-out and effete inhabitants with the brawn, brain, and character of the country boy and girl. The harsh, arbitrary methods sometimes directed against the farmer are not only unjustified, but delay and complicate the solution of the milk question. Much quicker progress will be made through mutual respect, a helpful attitude, and a certain amount of patience necessary for all large sanitary reforms. $^{5}$

The dairy farmer is pressed by the health authorities for better quality of milk and by the dealer for minimum prices. He is not a recalcitrant; he is as glad to 
help "save the babies" as anyone else, but he must live. In many districts dairy farmers are in fact going out of business. Yet the milk supply must not only be kept up but be increased. The well-being of the farmer is necessary to that of society, and the maladjustment of the conditions under which he operates must be corrected.

\section{The Farmers' Need of Organization}

The one conspicuous feature in the situation of the farmer is his lack of organization. In his relations with dealers and railroads he is at a great disadvantage in his inability to bargain collectively. It is no wonder that he is at the mercy of shrewd price-setting milkbuyers. If he carries on his business as an individual he is unable either to recognize the true nature of the conditions which he shares with other dairymen or to act effectively to secure his due. Organization among farmers would alter the whole situation. Such organization would first of all protect and advance the farmers' collective interests, and might then perhaps proceed to such constructive work as the establishment of co-operative creameries and, in co-operation with agricultural authorities, the improvement of dairying methods and of agriculture in general.

Farmers' organizations now exist, to be sure, but these have not, in general, been sufficiently close-knit and active to produce much impression on the situation. Collective action has been spasmodic, shortsighted, unsystematic, accompanied by no continuous grip on affairs. Too many farmers have "stayed out." The farmer is by nature a conservative and an in- 
dividualist, too ready to tolerate disadvantages. But if he is to hold his own under modern competitive conditions, he must, as a class, learn the lesson of organization and collective action. Signs of a changing attitude are to be seen, as, for example, in the present efforts of organized producers in New England and the New York district to secure better milk prices (see Appendix E), but there is much to do in this direction if the individual farmer is not to continue to be forced out of business as a milk producer under present-day pressing conditions.

The sympathies of a disinterested observer would likely be with the consumer, who is in darkness, and with the farmer, who suffers most under economic pressure. But the difference is that the consumer must look to the authorities for his protection, while the farmer can, if he will, better his own conditions.

\section{Agricultural Aid}

The chief external reliance of the farmer for the improvement of his status must be the agricultural authorities who are studying his problems on scientific principles. State and Federal departments of agriculture with their experiment stations, not to mention various agricultural colleges, are constantly carrying on investigations and publishing data and advice of advantage to the farmer. A great deal of this work is specialized on the dairy industry. The following paragraph by Mr. H. N. Parker sketches the part played by such authorities:-

The agricultural experiment stations naturally see the farmer's position and, perhaps, only less clearly, the con- 
tractor's. For years station men have been collecting data on dairying. They know, as no one else does, that the modern dairy farmer has large sums of money invested in his business and that he must be a highly trained man in order to succeed. They appreciate fully that the profits in dairying are not easy and that only careful management can reap them. Consequently, the stations have labored zealously to get dairymen to adopt economical rations, to weed out non-productive or robber cows, to pay attention to breeding, and to be biologically clean, so that the products may be wholesome and of good flavor. ... They know that dairying must pay a reasonable profit to be sound, hence the stations have tried to make the dairymen efficient and have protested when regulations have been proposed that sounded good and entailed expense, but yielded no adequate benefit. The work of the stations will grow in importance, for at present it is the hope of improving farm conditions that holds out the brightest prospect for a solution of the milk question. ${ }^{6}$

One cannot expect that farmers will become agricultural experts overnight. Nevertheless, efficient farm management has a prime part to play in solving the milk problem, and there is substantial truth in the foregoing estimate of the rôle of agricultural authorities. Farming is not yet, for the many, a technological calling, but it is a trade demanding knowledge of scientific and business principles. It may be that agriculture will of economic necessity follow the modern trend and become as specialized as manufacturing. But that is, for the present, a development which interests only the comparatively few of special training and enterprise. Meanwhile the ordinary farmer must make the progress that is within his 
power, in which endeavor his chief advisers must be the agricultural authorities and many of his best textbooks will be their bulletins. It rests with himself as to whether he will take advantage of his opportunities.

\section{THE POSITION OF THE DEALER}

The modern development of the milk business has brought into existence a highly important factorthe person or concern known variously as the middleman, distributer, retailer, contractor, or dealer. He is the successor of the farmer-retailer who enlarges his business by collecting and selling milk from his neighbors, but is a different type in that he is distinctly a business man. He occupies to-day, in the larger cities, the central position in the milk situation. Reaching far out into the country districts by means of the railroads, collecting and distributing on a large scale, he connects, at the same time that he separates, producer and consumer. This middleman business involves large investments of capital and is one of the "big businesses" of to-day.

In milk controversies in the large cities it is the middleman who seems to hold the key to the situation. Under ordinary conditions he virtually sets both the price paid to the producer and the price to be charged the customer, and he will not readily make concessions at either end. Being a better business man than the farmer, it is natural to infer that he reaps the lion's share of the profits.

In certain respects, this concentration of the milk business is, as Rosenau points out, an advantage. It makes for economic efficiency and at the same time 
tends to simplify sanitary supervision. Certain large dealers, recognizing the necessity of sanitation, have co-operated in the efforts of the health authorities and have established laboratories and inspection systems of their own. Such measures are not philanthropic, but have been undertaken as good business management and in the desire to maintain a good standing. In the same way some have established bonuses for milk produced under superior sanitary conditions. Milk-borne disease is a bugbear of the large dealer and, to avoid it, he has been willing to go to considerable trouble and expense and to adopt pasteurization and other precautions. The reputable dealer welcomes better conditions in the milk industry, but he is not to be expected to go to extra expense that will place him at a disadvantage with his competitor. In fact the progressive, fair-minded dealer will co-operate in sanitary improvements, but naturally only so far as they are required by authority, or at least where they do not conflict with his interest as a business man.

In relation to the farmer, the point of vantage of the middleman lends itself to price-squeezing in the producing districts. Of the two means of profit, the dealer finds it easier to keep down the price paid to the farmer than to raise the price received from the consumer. The producers in a given district may complain, but, unless they are organized, they must either take the price offered by the dealer who collects in that district, or none.

It is no doubt to the advantage of the middleman to discourage agitation regarding conditions in which he holds the balance of power. Nevertheless, the 
situation in some quarters has reached such a pass that the abolition of the middleman through the establishment of farmers' co-operative selling or through other co-operative or municipalization plans is being seriously discussed. But this leads us to considerations which must be postponed to later chapters.

\section{RAILROADS: THE TRANSPORTATION PROBLEM}

A special matter which calls for attention in connection with the milk supplies of large cities is railroad transportation. Wherever milk is brought by rail from long distances special sanitary precautions are necessary, principally with regard to refrigeration, while the railroads find it necessary to institute divisions of milk transportation with provisions for special cars, fast milk trains, depots, etc. The Pennsylvania Railroad, for example, a few months ago purchased at a reported expense of $\$ 300,000$ thirty-six refrigerator cars to carry milk from northwestern New York and Pennsylvania into the cities of Philadelphia, Brooklyn, Baltimore, and Jersey City, the amount carried at that time being 265,000 quarts per day. These cars have a capacity of 12,000 quarts each, and brine and cold air facilities for holding the temperature down to $40^{\circ} \mathrm{F}$.

The transportation problem has appeared in acute form in certain regions. The question of rates has been taken up by the Interstate Commerce Commission, which has held hearings, e. g. (in 1916) in Boston and Philadelphia. The complex situation in New England has also been made the subject of investiga- 
tion by the Boston Chamber of Commerce (see Appendix E). Such investigations run into complications as to systems and rates which it is impossible to discuss here.

It is, of course, difficult to say to just what extent the transportation question enters into the general milk problem, but it evidently constitutes one phase,a phase, moreover, which is used as a background for exhibiting miscellaneous difficulties and grievances.

It is worth noting, in passing, that, while suspicion has fallen upon "railroad milk," still, with the growth of cities, the milk supply must be drawn from greater and greater distances. Fortunately it is possible so to compensate for distance by means of proper precautions that a sanitary milk from two hundred miles away may be better and safer than one produced near by but subject to unfavorable conditions. The final quality of the product is the criterion.

\section{THE ATTITUDE OF THE CONSUMER}

The attitude of the consumer is, on the whole, negative. As one health official puts it, "Milk is milk to the average consumer. A white fluid in a bottle, with a cream line, is about all he seems to be interested in." The agitation on the milk question is not carried on by the many but by the very few who have interested themselves and formed "consumers' associations" and the like. The great majority demand only a sufficient appearance of cream and the absence of obviously visible dirt, and are aroused only by an increased price.

This attitude is unfortunate when there comes ques- 
tion of sanitary measures for which public support is required. One authority goes so far as to say:-

Probably the chief obstacle ... lies at the consumer's end of the problem. . . . It is still unusual to find even educated people willing to pay a cent a quart more for good milk when they find they can get an ordinary kind cheap. If the public can only be brought to appreciate the fact that it is cheaper to pay a little extra for a good quality than to pay less for a poorer grade of milk, a great reform can be rapidly brought about. The question whether the milk supply can be generally improved depends thus upon the consumer. . . This reform will come just as soon as the public is ready for it, and that will be just as soon as the consumer is ready to pay for quality. ${ }^{7}$

In a city which was attempting to enforce a tuberculin-test ordinance, users of milk informed the health authorities:-

They could see no difference between the milk from a tuberculin-tested herd and the milk from an untested herd. They have explained that the cream line was no lower, that the milk tasted no differently, and that they could see no excuse for paying a higher price for such milk. This attitude, more or less exaggerated, was apparent and general and of course makes for the defeat of a provision like that requiring the test. The dealer can quite safely oppose any requirement until the public demands it. ${ }^{8}$

There is this, however, to be said for the consumer: that his inability to judge or control conditions naturally makes him passive. His unwillingness to pay more for milk is not unjustifiable if he has no way of knowing that the quality is actually better. Far from expecting the consumer to take a direct hand in the 
matter, one should look to health authorities and legislatures to perform their duty in ensuring that his welfare is protected. On this score he often has good ground for complaint in that even the most intelligent inquiring citizens often find great difficulty in making out what the local milk situation is or which supplies are most worthy of patronage.

A great deal has been said about educating the public to demand better milk at a just price, and the stimulation of such a demand is, to be sure, a good thing. But the best intentions of the consumer are ineffectual unless the public health authorities so deal with the situation as to make discrimination by the citizen simple and direct. As to the means of doing this, more will be said later.

\section{THE PHYSICIAN}

The medical profession has played a large part in the promotion of the sanitary milk movement,-most definitely through the development of certified milk. It is the medical observer to whom we turn for knowledge of the relation of milk to the individual. In the case of the infant, the invalid, the convalescent, the doctor's choice of milk is important, and regulation of milks must therefore harmonize with medical requirements.

\section{UNOFFICIAL ORGANIZATIONS •}

An important part has been played by unofficial organizations of public-spirited citizens and even by individuals. Civic bodies, such as women's clubs, have done much in stimulating the public sentiment which 
is a necessary preliminary to and power behind effective legislation. Milk distribution from infants' milk depots has been a useful constructive activity.* In many ways such bodies have encouraged and supported health authorities, and they will continue to do so.

\section{THE LEGISLATOR: MILK AS A POLITICAL ISSUE}

Milk figures not infrequently as a political issue. A chapter might be written on milk in politics; it would, however, be more confusing than illuminating. An already contradictory subject is further complicated by the partisans of special interests. Legislators are too apt to aim at something less than a general solution of the problem. Some seek to gain favor with the city voter by "pure milk bills," while others score with the farmers by their opposition to such bills. All this is unfortunate in its confusing and obstructional effect, but it has, at the same time, brought out the importance of the whole question with its several sides. It has shown the necessity of, first, unbiased legislation and, secondly, non-partisan administration of milk laws.

Clarification of the whole matter will, it scarcely need be said, tend to remove it from political entanglement. Further, as regards the interpretation of milk laws by the courts, the adjustment of values is necessary as the basis of right decisions.

* It is to be noted, however, that the distribution of milk is now considered by no means the most important part of milk station or infant welfare work. (See pp. 20-21, 87-88.) 


\section{RELATIVE IMPORTANCE OF MILK CONTROL}

The question may well be raised as to the exact importance of milk control in the general sanitary field. Until recently no idea at all definite was to be had of this, but a tentative scale of relative values in public health work has been published by Dr. Charles V. Chapin, ${ }^{9}$ Superintendent of Health of Providence, R. I., in which, on a scale of 100 , a value of 8 was assigned to milk supervision. Dr. Chapin, in a revision of the scale, has since, however, reduced his estimation of the milk figure to 2 per cent (sanitation, 1.7 ; adulteration, 0.3). ${ }^{10}$ A similar scale has been worked out by Franz Schneider, Jr., ${ }^{11}$ of the Department of Surveys and Exhibits of the Russell Sage Foundation, assigning to milk control the value of 2.7 per cent. These figures, though tentative, tend to indicate that the relative sanitary importance of milk control is not so great as has perhaps been generally supposed. It must be considered, however, that the economic difficulties and demoralization of the vast dairy industry contribute greatly to the present importance of the milk problem as a whole.

\section{CONCLUSION: THE STATE OF THE CASE}

The present status of the milk question as outlined in the foregoing pages may be briefly characterized as follows:-

1. The problem is both sanitary and economic. It involves the all-important question of health versus dollars-Will the consumer pay for sanitary milk?and the correlative one: How, otherwise, is the dairy- 
man to make a living by producing it? Also the further one: How can sanitary milk be produced and distributed most economically?

2. It arises from the separation of producer and consumer and from the complexities necessited by urban development. It is characteristic of centers of population and tends to become more acute the larger these centers and the greater and more distant the territory from which the milk supply is drawn. At the same time all milk supplies, under whatever conditions and in all communities, are subject to the same fundamental sanitary considerations; hence even comparatively small communities may have more or less of a milk problem.

3. A practical difficulty in its solution is that several distinct and important parties are concerned in the case: not only must the sanitarian, the health official, and the consumer be heard, but also the producer and the distributer. Hence there is always debate, often controversy, and sometimes a "milk muddle." The task is to get the facts free from the coloring of special interests and prejudices and do justice to all parties.

At a recent Federal hearing in New England the following statement, summarizing the acute phase of the matter, was made by a representative of large milk interests:-

An important point which Mr. made, under crossexamination by Attorney-General - , was that the great milk problem, both in regard to cleanliness and price, is pressing for a solution; and whether it is solved now or later, the agitation by the public will continue until the solution is reached and the matter is settled once for all on a 
basis fair alike to producer, shipper, and consumer. Milk, the witness said, is so vital to a large part of any metropolitan community that in some degree it may not be too much to say that life depends upon it-and a matter so close to the life of the community enforces constant attention. ${ }^{12}$

In the following chapters the aim will be to outline the measures of sanitary control, to show wherein previous and present regulation is inadequate, to set forth the general economic considerations, and to deduce the main principles of equitable adjustment. 


\section{CHAPTER III}

\section{THE SANITARY FACTORS}

With a view to indicating the present status of the sanitary control of milk supplies, we may now consider briefly each of the means of control. These are directed toward attainment of the general ideal set down at the close of Chapter I.

The subjects will be treated in the following pages in the order, roughly, of chronological development. There will be seen a gradual evolution in regard to the point of attack. The earliest regulation was directed at preventing adulteration; in the next stage the conditions under which it was produced and handled received most attention; recent developments have centered about the sanitary quality of the product as determined by laboratory methods and about the specific treatment known as pasteurization. The development has not been, however, clearly defined, and the regulations of the present day are a mixture of the ideas of all the stages. The present-day task of sanitation is to assign to each of these ideas its proper weight.

\section{Early Developments}

We shall not here go into the history of milk regulation except as it has a direct bearing upon still surviving traditions. This, however, is by no means a negligible consideration, for in control of milk supplies, as in 
other branches of sanitary endeavor, the inertia of traditional ideas and routine has been great. - To-day there may be seen the most advanced and promising ideas in operation side by side with the archaic - the latter still largely prevailing.

To find the beginnings of milk supply control in the United States in anything resembling the modern sense, we must go back some twenty-five or thirty years. The following passage from a paper by $\mathrm{Mr}$. H. W. Parker epitomizes those beginnings:-

Most people think that the milk question is new in America, that it appeared not over twenty years ago, but really it began to make itself felt in the big cities at an earlier period. Thus, in 1859 the office of milk inspector was established in Boston; in 1870 the Board of Health of Providence investigated the milk supply of that city; and in 1871 the board of health of Washington looked into that of the Federal city. But in a sense the public is right, for the regular collection and analysis of milk samples did not become common in American cities until the period from 1885 to $1890 .^{*}$ It seems probable that about this time the family cow disappeared and dairymen found it necessary to locate so far from their trade that they found it difficult to deliver milk in good condition and had lost personal contact with their customers. $^{1}$

The efforts at this time were very largely directed against watering, skimming, and other forms of adulteration or sophistication, which were very common at the time. This work was certainly necessary, and still

* Sedgwick and Batchelder's work, mentioned below, indicates, however, that the beginnings of bacteriological control were somewhat later.-J. S. M. 
has a justified place in the supervision of milk supplies. But, owing to the work of the past, heavy penalties, and the ease with which adulteration and the use of preservatives can be detected, the period of extensive adulteration is over, and the matter is now one of little significance. It has always been, too, a question of fraud rather than of health.*

The logical development of these early efforts at milk control was the adoption of chemical standards, which will be considered later.

\section{THE BEGINNINGS OF THE CLEAN MILK MOVEMENT}

For many years milk supply reform was summed up in the movement for "clean milk," which may be defined as milk from healthy cows, handled throughout under sanitary conditions to be obtained by means of inspection. Bacteriological examination became its indispensable gauge, and later there was added to the ideal the tuberculin test for dairy cows. Under the influence of the movement the dairy score card for inspection developed. This was an ideal of fresh raw milk; hence many of its adherents, until recently at least, have minimized or opposed pasteurization, thus giving rise to a controversy, now largely adjusted to which we shall again allude under the latter head.

Attention was drawn to milk as a vehicle of infection, through a study, laid before the International Medical Congress of 1881 by Mr. Ernest Hart, sum-

* Dr. Charles V. Chapin, in a recently devised scale of sanitary values totalling 100, assigns to milk adulteration a value of but 0.3 . (See p. 61.) 
marizing sixty-nine epidemics which had already been charged to milk. ${ }^{2}$ The sanitary importance of contamination in general was later brought out strikingly by Sedgwick and Batchelder, ${ }^{3}$ who in 1892 published the results of a bacteriological examination of the Boston milk supply. This seems to have been the earliest recording of the bacterial content of the milk of an American city. The large numbers reported amazed sanitarians and public. The modern movement for sanitary milk on a bacteriological basis appears to have dated from this time.

\section{Certified Milk ${ }^{4}$}

But even before this, important action was under way in New Jersey, where the State Medical Society, with the object of improving milk production, began, in 1889, an investigation of milk supplies, the result of which was an appeal to the State for strict supervision of all the dairies within its limits. This appeal failing, resort was had to an original expedient, that of medical certification of milk, and in 1893 the production of the first "certified milk," under the supervision of a medical milk commission organized in Essex County, in that State, took place.

Certified milk may be briefly defined as milk produced under the strictest sanitary conditions by a producer who has entered into an agreement with a medical milk commission by which he stipulates compliance with the commission's requirements, while the commission authorizes the use of its certification.* In

* The term "certified milk" has sometimes been abused by unscrupulous dairymen, but has been legally protected in a number of 
effect, certified milk is the highest quality of raw milk, from tuberculin-tested cows, the bacteria count being limited to 10,000 per cubic centimeter. The total production of certified milk is estimated at 25,000 gallons daily; this, however, is but a drop in the bucket, for even in the large cities where certified milk is established it constitutes less than one per cent of the total milk supply.

The certified milk idea was, until recent years, undisputedly predominant in the clean milk movement and so has served its purpose. In the solution of the general milk problem, however, certified milk plays little part. Its market will continue to be restricted and its quantity small because of the high price at which it must be sold, and vice versa. This price averages 14 cents as against an average for ordinary market milk of about 8 cents. While some of the excess may be due to lack of business methods among producers, it is chiefly necessitated by the expense of special equipment and methods and by the small scale of production. It is, of course, true that if certified milk were more widely used, some elements in its cost-such as supervision and distribution-would be cheapened, but the price must evidently always be decidedly higher than that of a widely used market milk.

States. On the part of the medical milk commissions the object is simply to insure, through special encouragement, a clinically satisfactory class of milk. Over sixty commissions have been established, though nearly one-third of the number have become inactive. A general organization exists in the American Association of Medical Milk Commissions, which has formulated methods and standards for the production and distribution of certified milk. The producers have also organized themselves in an Association. 


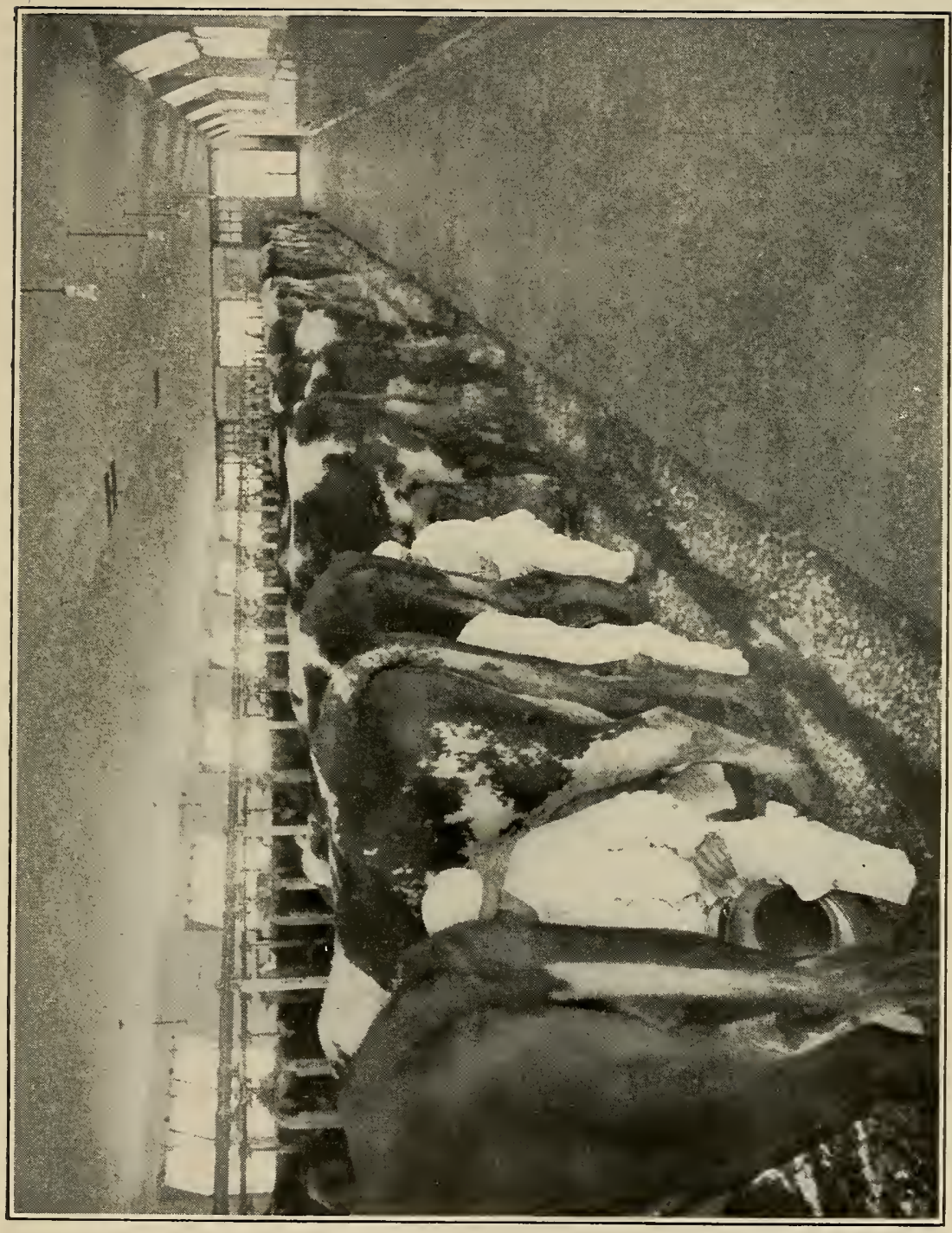

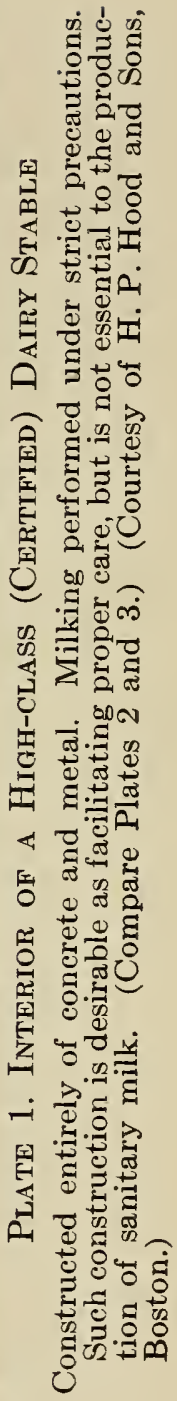



The general practical weakness of certified milk is that it demands multifarious precautions to obtain a result which, as we shall show later, appears to be obtainable by much simpler and less expensive means.

It must also be remarked that medical milk commissions have undertaken, through practical exigency, a function of supervision which properly pertains to the public health authorities. While they have served, and continue to serve, a useful purpose, it is a fact that, as official control becomes better and better developed, the value of such unofficial or quasi-official bodies diminishes toward the vanishing point. It is simply an evidence of deficient development in public health protection that in many communities certified milk is the only milk distinguished as a standardized class from the bulk of the market product, and that in many more others there is no milk at all of such definite characterization.

While the highest ideal of clean milk has been attained in certified milk, which is therefore of a high degree of safety, it must be remembered that absolute freedom from possibility of infection is not guaranteed by this ideal. This, as we shall see later, is the general weakness of the clean milk ideal; no milk, even the most "clean," can be called perfectly safe that has not been pasteurized.

\section{THE GENERAL CLEAN MILK MOVEMENT}

Certified milk established a standard which has been the ideal of the whole clean milk movement. This movement, originated thus by unofficial endeavor and taken up by health authorities, sought to attain 
its aim primarily by means of inspection, the results being checked up by bacteriological examinations of the product. A later development was the tuberculin test, which will be discussed further on in this chapter. Many of those who held the clean milk ideal opposed pasteurization as an undesirable palliative and relied on the above means for keeping infection out of milk so that the protective process of pasteurization would not be necessary.

In practice this ideal has been well developed by Richmond, Va., Seattle, Wash., Portand, Ore., and Montclair, N. J., in which last community vigilant supervision of the milk supply was begun with a reorganization of the health department which took place shortly after the establishment, in the same State, of the first certified milk supply. That this reorganization came about as the reaction to a severe epidemic of typhoid fever is an indication of the kind of stimulus sometimes necessary to arouse a community to sanitary reform.

\section{THE SCORE-CARD METHOD OF INSPECTION}

The development of dairy inspection and the tendency to standardize its methods led to the devising of the dairy score card, which deals with itemized conditions each of which is given a mathematical rating, the total number of points for a perfect dairy being 100 .* $^{*}$

* What appears to have been the earliest dairy score card was introduced and used by Dr. Wm. C. Woodward, Health Officer of the District of Columbia, in 1904. Since that time a number of different cards have been devised and put in use, and the idea has been extended to the rating of milk plants and stores handling milk and to other purposes. 
The most representative of the various cards which have been devised is that adopted by the United States Department of Agriculture in concurrence with the National Association of Dairy Instructors and Investigators. The most important feature of this card is its separation and weighting of equipment and methods: to the former a total of 40 points is allotted; to the latter, 60 .

The score-card method has been commonly accepted as the standard basis of inspection and recording, both for dairies and for milk plants. Dairy scores have come to be widely taken as indicating, at least approximately, the quality of milk produced under the given conditions and are frequently published as ratings of milk supplies. Score requirements have been generally incorporated in grading systems and, in one case at least (New York State), have been authorized as a sole basis of grading. The exact value of the score card demands, therefore, most careful consideration.

\section{The Dairy Score Card Under Criticism}

It is a curious fact that the score card has been so unconsciously accepted as a sanitary index that little attention has generally been paid to the question of the exact relation between dairy scores and bacteria counts.* Such study as has been devoted to the matter,

* Throughout the following discussion it is assumed that the ordinary bacteria count, properly performed according to standard methods, is a fairly accurate criterion of biological cleanliness. Discussion of the exact merits and present status of the count is beyond our present scope. See, however, paragraph $c$, p. 74, and notes on pp. 92, 94 . 
however, has shown results highly destructive of preconception. An investigation of the bacterial count of the milk from 34 commercial dairies and their scores as determined by three representative cards-namely, the Cornell card, the United States ("Official") card referred to above, and the New York City card-has recently been published by the New York State Agricultural Experiment Station, the investigator being James D. Brew. ${ }^{5}$ The purpose of this study was to determine how nearly different cards agreed when the same conditions were scored simultaneously by the same person and what relation existed between score and bacteria count as an index of sanitary quality. As might be expected, there was found some variation in the relative positions of the various dairies when scored simultaneously with all the cards. But the striking conclusion derived was this:-

The results of the investigation show no correlation whatever between the quality of the milk so far as it could be determined by laboratory methods and the score as expressed by any one of these three cards.

This is so arresting a result that we must quote further from the conclusions of the investigator:-

Milk of all grades ranging from the finest quality to the poorest, is produced in barns which would be excluded on account of low scores. All grades of milk are likewise produced in the high-scoring barns.

The real explanation for this lack of relationship between the scores and the bacteria counts cannot be given as yet with absolute certainty. The most apparent reason, as shown by investigations made at this Station, is that a 
large number of the items included on the score card have little or no effect upon the number of bacteria present in the milk. In other words, too great emphasis is placed upon unessential factors in all of the score cards studied, with a consequent lessened emphasis upon the factors which actually do affect the milk.

Some may contend that these findings encourage the production of milk under filthy conditions. This contention will be raised only by those who hold the idea that lowscoring dairies are necessarily unsanitary and filthy. Such conditions have, however, not been found to hold true in the region studied because low-scoring dairies were found which vied in cleanliness with the most ideal of the high-scoring dairies. On the contrary, however, these facts give decided encouragement to the intelligent dairyman who finds that he can produce high-grade milk by the simple observation of the few essential factors of cleanliness and care. This places him in a position to secure a greater profit from his business while at the same time he has the moral satisfaction of knowing that he is selling a high-grade article. Where the present score cards are used, all dairies, in order to get credit for Grade A milk,* are forced to an additional expense and consequently to an increased cost of production. At the same time a compliance with the score-card requirements carries with it no guarantee that the quality of milk will be improved or rendered more safe from the standpoint of public health.

The fact that high-grade milk can be produced with simple equipment, likewise gives encouragement to the consumer who is as much interested in keeping down the cost of producing high-grade milk as is the producer.

The above study deals with correlation in a general and unmathematical sense. A closer criticism of the * New York State. 
results would require their expression in exact statistical correlation figures. Such have been worked out from the original data and presented with inferences, which corroborate and supplement the original ones, by Dr. J. Arthur Harris. ${ }^{6}$ Dr. Harris's analysis, by means of the statistical figure known as the "correlation coefficient," leads to the following conclusions:-

a. The correlation between the total scores assigned the same barns by the same inspector using the three most important cards is only about three-quarters of its theoretical maximum value. The correlation between the scores for methods only is less than half its theoretical value.

$b$. There is practically no correlation at all between the scores assigned the barns by dairy inspectors and the bacterial content of the milk which they place upon the market.

$c$. When correlations as low as those deduced from the present figures are found between the bacterial counts of morning and evening samples of milk from the same barns, it is clear that much remains to be done in the perfection of the technique of sampling and bacteriological analyses of milk.

These data show how flimsy is the basis for the common belief that there is a relation between the score of a dairy and the quality of the milk produced by it, and how premature the official sanction for the grading of milk by means of dairy scores.

The practical significance of such findings and earlier ones of others, ${ }^{7}$ taken in connection with the considerations which we shall next review, is that the present score cards are extremely inefficient instruments of sanitation. While Mr. Brew does not construe his results to disprove the value of the score card idea, he 
is constrained to say that "present score cards cannot be satisfactorily used as means of grading milk according to quality."

Going back for a moment to the origin of the present score cards, we find that, in the words of other investigators along a related line (H. A. Harding * and others, also of the New York State Agricultural Experiment Station):-

When health officials, failing to find other means of characterizing sanitary milk, undertook to specify the conditions under which it should be produced they were confronted by an almost total lack of detailed information upon this subject. This lack arose from the fact that the available studies upon milk sanitation were in the nature of general surveys of the situation. While these general surveys were a necessary preliminary, they gave little information as to either the absolute or the relative importance of any given dairy operation.

Later these official dairy regulations took the form of score cards. These cards not only selected certain operations as important but assigned to each of them a definite numerical value.

This arbitrary selection of values in the absence of definite information upon the subject has frequently done injustice to the dairy business and can be justified only upon the ground of the urgent need of official action. The importance of the interests involved demands that the needed information shall be furnished as promptly as possible. ${ }^{8}$

Mr. Brew, also, says that "there is little hope of designing a score card which will accomplish this purpose [of grading milk according to quality] until all of the

* Now of the University of Illinois. 
factors which are thought to affect the quality of milk in any way have been carefully studied and the influence of each determined and accurately measured. In this way the really important factors can be singled out and given the proper value on the score card."

What these important factors are will be considered in the following section, after which the question of the feasibility of amending the score card will be taken up again.

\section{RATIONAL METHODS IN CLEAN MILK PRODUCTION}

The impression which has long been growing upon acute observers, that the production of clean milk is not the complicated matter that it has been supposed to be, is now scientifically confirmed. For a number of years some highly significant experiments have been carried on by Harding and others ${ }^{*}$ at the New York State Agricultural Experiment Station on the proposition that "there is great opportunity for economy in sanitary milk production through the saving of useless labor." These experiments, conducted with reference to single dairy conditions and operations, show that certain of these, commonly thought influential, really exert little or no influence on the germ content of the milk. Following are some remarks from this study (italics inserted):-

* In actuality these experiments were antedated by those of Dr. North which resulted in his system described below (cf. Appendix C), but it seems logical to introduce them at this point on account of the general nature of the ideas brought out by them. 
In public discussions of clean milk, the certified milk standard of 10,000 germs per c.c. is ordinarily taken as insuring a milk which is above suspicion of uncleanliness. In obtaining milk which shall be safely below this 10,000 limit, it is the custom to expend much labor in washing the cows and in keeping the interior of the barn scrupulously clean. . .

Those who have followed recent discussions of germ content of city milk and particularly those who are familiar with the extreme precautions which are taken by many of the producers of certified milk will be struck by the small germ content which has characterized the milk obtained [by simple scientific methods] during these experiments . . . the large number of counts which are under 1,000 germs per c.c. . . .

This milk was produced under general conditions which appear to be no better than those surrounding a considerable number of the ordinary city dairies, conditions which probably would not be acceptable to any certified milk commission....

The important fact which is being gradually recognized through these and similar observations is that the production of a reasonably clean and low-germ-content milk will be a far simpler and less expensive undertaking when the factors which really govern its production are actually understood.

Some of the separate factors are dealt with in the conclusions as follows:-

The cleanliness of the interior of the stable, within a fairly wide range, had no measurable effect upon the milk.*

The protection of milk pails from accidental contamination after they had been thoroughly steamed had a measurable effect in reducing the germ content of the milk.

* A recent number of the Journal of the American Medical Association (Sept. 2, 1916, p. 746) has an editorial entitled "The relation of stable air to sanitary milk," asserting that aërial contamination in milking is negligible. 
When all of the utensils had been carefully steamed, cooling and straining the milk resulted in only a small increase in germ content even when this was done under what would ordinarily be considered as rather unfavorable conditions.

By removing some of the misconception which has grown up as a result of the misplaced emphasis, by both certified milk rules and score cards, on dozens of minor details, such findings as those quoted in the foregoing pages clear the way for the acceptance of simplified methods of sanitary milk production.

\section{The North System}

The idea of rational simplification has taken concrete form in the system of sanitary milk production devised by Dr. Charles E. North, a consulting sanitarian of New York City. This system carries to a logical conclusion the emphasis upon methods as opposed to equipment; it centers around a few simple requirements which may be asked of any farmer, and, on the commercial side, compensates the farmer through a rational scale of payments. The application of the ideas exemplified by Dr. North's practice should, on present showing, revolutionize the practical production of clean milk by making it possible for such milk to be profitably produced by ordinary farmers on ordinary farms without expensive equipment and at a reasonable cost.

The fundamental factors upon which this system is based have been simply stated by Dr. North. Eliminating all non-essentials or matters of secondary importance and including those only of primary importance and "which even alone are sufficient to produce under the conditions found in ordinary dairies a milk so clean 
that it will have with great regularity a bacterial count of less than 10,000 bacteria per c.c.," the list is as follows:-

1. Milking with clean, dry hands, into covered (i. e., smallmouth) pails from udders free from loose dirt; *

2. Sterilization of pails, cans, strainers, etc., with boiling water;

3. Cooling milk by submerging cans in tanks of spring water or ice water.

To which are added as measures of control:-

(a) The taking of samples at shipping stations for frequent bacterial tests (at least three times per week);

(b) The payment, to the producers, of premiums (10c. or 20c. per 40-quart can for milk testing below the bacterial standards established, 25,000 to 10,000 per c.c.). ${ }^{10}$

The complete bacterial trans-

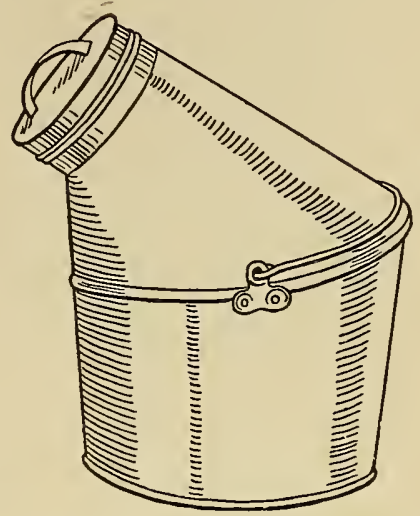

Fig. 11. The SMaLlmouth Miluing Pail

An important utensil in clean milk production. By its use the amount of bacteria-laden dust and dirt falling into the milk at time of milking may be reduced by as much as 90 per cent. There are a number of types of such pails. This one, used by farmers working under Dr. North's system, is provided with a cover to protect it after sterilization. formation, in five different localities under Dr. North's supervision, of large volumes of milk produced by many

* It might perhaps be thought that the use of the milking machines which have been introduced in some localities would assist in obtaining a low-germ-content milk. Experience, however, has shown that the milking machine is apt not to be thoroughly cleaned and sterilized and may therefore add large numbers of bacteria to the milk. (Ruediger, Gustav F., Jour. Inf. Dis., vol. XIX, Oct., 1916.) 
dairy farms justifies the conclusion that the measures employed must be fundamental. A strong point of the system is that the farmer is asked to do only those few things which it is essential that he do, while other functions are centralized in a well-equipped country milk plant, which acts as a combined dairy house for all the farms.*

Where such a plant is established the requirements for the farmer may be reduced to Nos. 1 and 3, steriliza-

* The division of requirements as to equipment between farmer and station is shown by Dr. North as follows:-

\section{"Farm}

"1. Cows, healthy.

2. Cows, tuberculin-tested.

3. Cows, sound udders.

4. Cows, not in calving period.
5. Cow feed, no strong flavor.

6. Cow feed, none unwholesome.

7. Milkers, no contagious disease.

\section{"Station}

"1. Water supply, pure.

2. Dairy-house, superintendent.

3. Dairy-house, employees.

4. Dairy-house, white uniforms.

5. Dairy-house, room for washing.

6. Dairy-house, room for sterilizing.

7. Dairy-house, room for cooling, bottling.

8. Dairy-house, laboratory.

9. Dairy-house, apparatus, steam.

10. Dairy-house, apparatus, power.

11. Dairy-house, apparatus, washing, sterilizing.

12. Dairy-house, apparatus, cooling, bottling.

13. Dairy-house, apparatus, pails, cans, bottles.

14. Dairy-house, ice, supply abundant.

"Those requirements relating to the general health of the cow must always be insisted upon, with the exception of tuberculin-testing. Clean milk can be produced from any kind of cows whether tuberculintested or not. I believe that tuberculin-testing is necessary only where milk is to be sold in a raw state." ("The Market Value of Cleanliness in Milk Production," address delivered at 36th Annual Convention, N. Y. State Dairymen's Association, 1912.) 


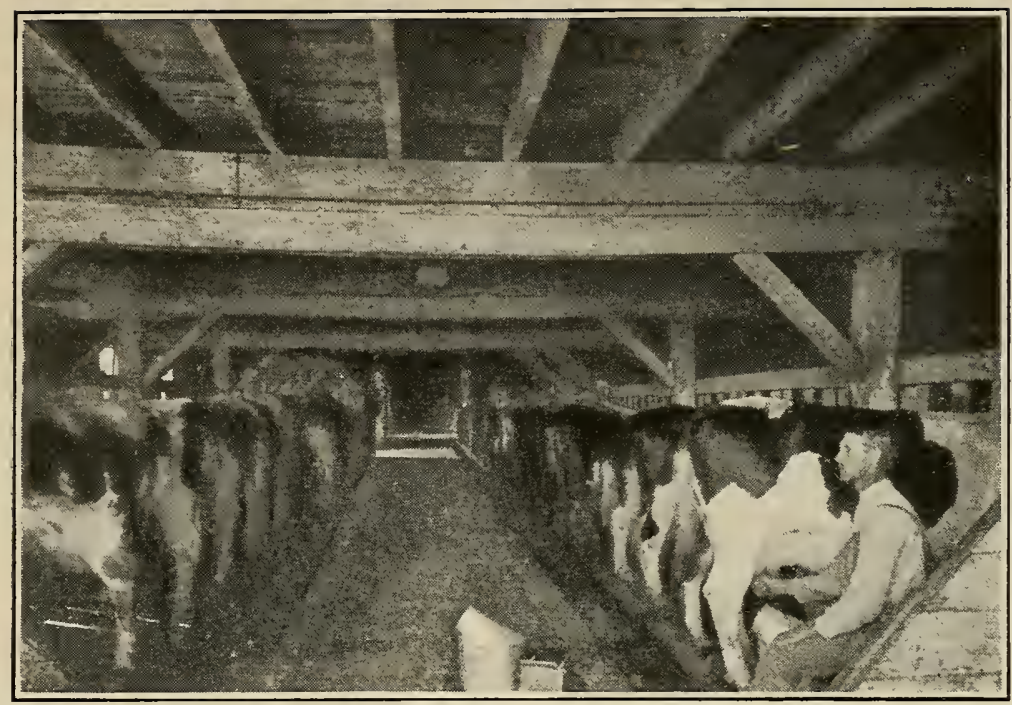

(a)

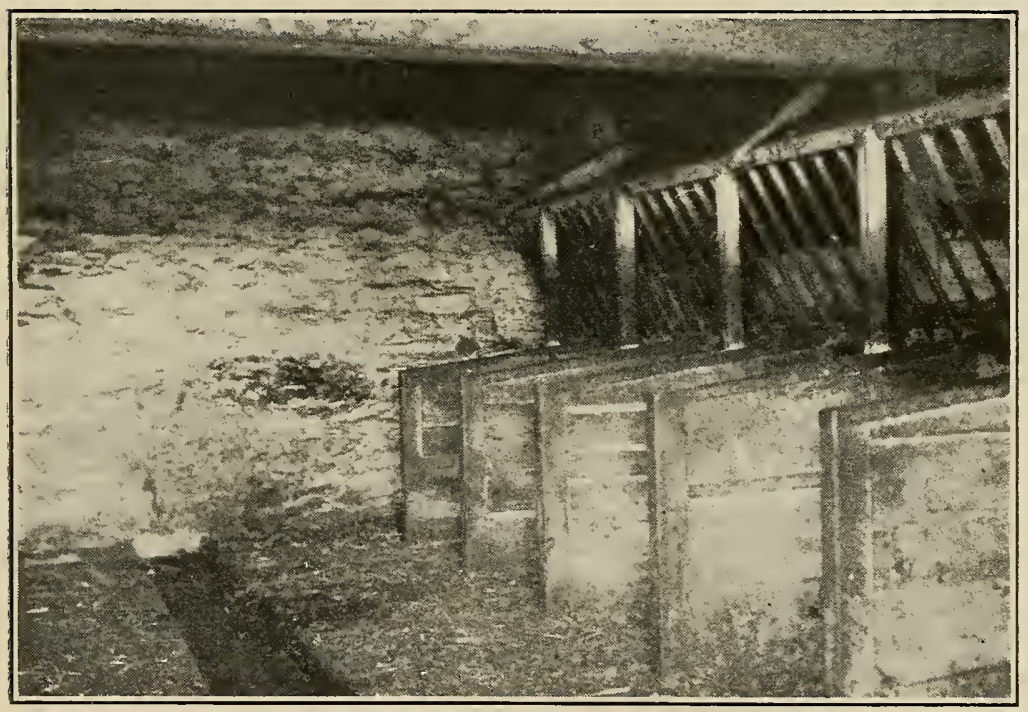

(b)

\section{Plate 2. Ordinary Dairy Stables in Which Clean Milk Is Produced}

(a) This is a dairy of fifty cows which consistently produces milk under 10,000 bacteria per cubic centimeter and the milk from which received the first prize at the New York State Fair in 1915 with a higher score than ever given to any milk in that exhibition, including even certified milk. (Courtesy of Dr. C. E. North, North Public Health Bureau, New York City.)

(b) A cow stable in Maryland in which milk is regularly produced with less than 10,000 bacteria per c.c. This barn is one in which horses are also stabled, and in which the light is very deficient and the floors of wood. (Courtesy of Dr. North.) 

tion of all utensils being performed at the plant. The contrast between the simplicity of this plan and the many requirements for certified milk, or even for good market milk under the score-card system, is striking.

Clean milk, requiring more pains and being worth more than dirty milk, deserves a certain premium. The extra cost under the North system is roughly indicated by the following figures, from the plant which was established at Homer, New York, by the New York Dairy Demonstrating Company. ${ }^{11}$

Premiums paid to farmers:

For tuberculin-tested cows............ 1/2c. per quart

For "sanitation" (milking into covered pails washed and sterilized at the receiving station, and cooling with ice) ......... $1 / 4 \mathrm{c}$. "

For keeping bacteria count under 10,000

per c.c.................... 1/4c. " "

Total..................... 1c.

(The payment plan also includes premiums for butter fat.)

A typical monthly bill made out to one of the dairymen supplying this station is as follows:-

New York Dairy Demonstration Co., Homer, N. Y., to Mr. Blank, Dr.

1912

Dec. 1 To 4,500 qts. of milk at $41 / 4$ c . . . . . $\$ 191.25$

To premium butter fat $3.9 \%$ at $2 \mathrm{c} \ldots \ldots . \quad 9.00$

To tuberculin test at $3-8 \mathrm{c} \ldots \ldots \ldots \ldots \ldots, 16.87$

To bacteria at $1 / 4 \mathrm{c} \ldots \ldots \ldots \ldots \ldots \ldots, 11.25$

Total. ..........................\$228.37 
In this bill it is seen that if this dairyman had sold his milk to a shipping station buying regular market milk for New York, he would have received $\$ 191.25$; but this bill shows that certain premiums are received by the dairyman of Homer, because he carries his milk to the Homer station. The fact that his cows were tuberculin-tested increased his check $\$ 16.87$; the fact that his milk contained a bacteria count averaging less than 10,000 for the month brought him in $\$ 11.25$. He also received a premium for richness, because his butter fat was above 3.7 per cent, which is the standard set by this station. ${ }^{12}$

The additional cost of running the station, over and above that of an ordinary bottling station, was $1 / 2 \mathrm{c}$, so that the additional cost of supplying a tuberculintested milk with a bacteria count under 30,000 at time of delivery was one and one-half cents a quart,-an amount which certainly cannot be considered excessive.*

Certified milk, owing to its requirements, which are out of reach of the rank and file of farmers, and its small volume of production, costs on the average 6 cents more than ordinary market milk. But here is milk of the highest grade, at a moderate cost, requiring for its production only an ordinary stable and equipment, healthy cows properly cared for (tuberculin-tested if the milk is to be sold raw), healthy milkers, and the exercise of exceedingly simple sanitary precautions.

(For further details the reader is referred to the fuller account of the North system in Appendix C, where a list of Dr. North's publications is also given.)

* If a non-tuberculin-tested but pasteurized clean milk be desired, the extra cost would be, on this basis, not over one cent. Milk can be commercially pasteurized for 1c. or less per quart (see Appendix D). 


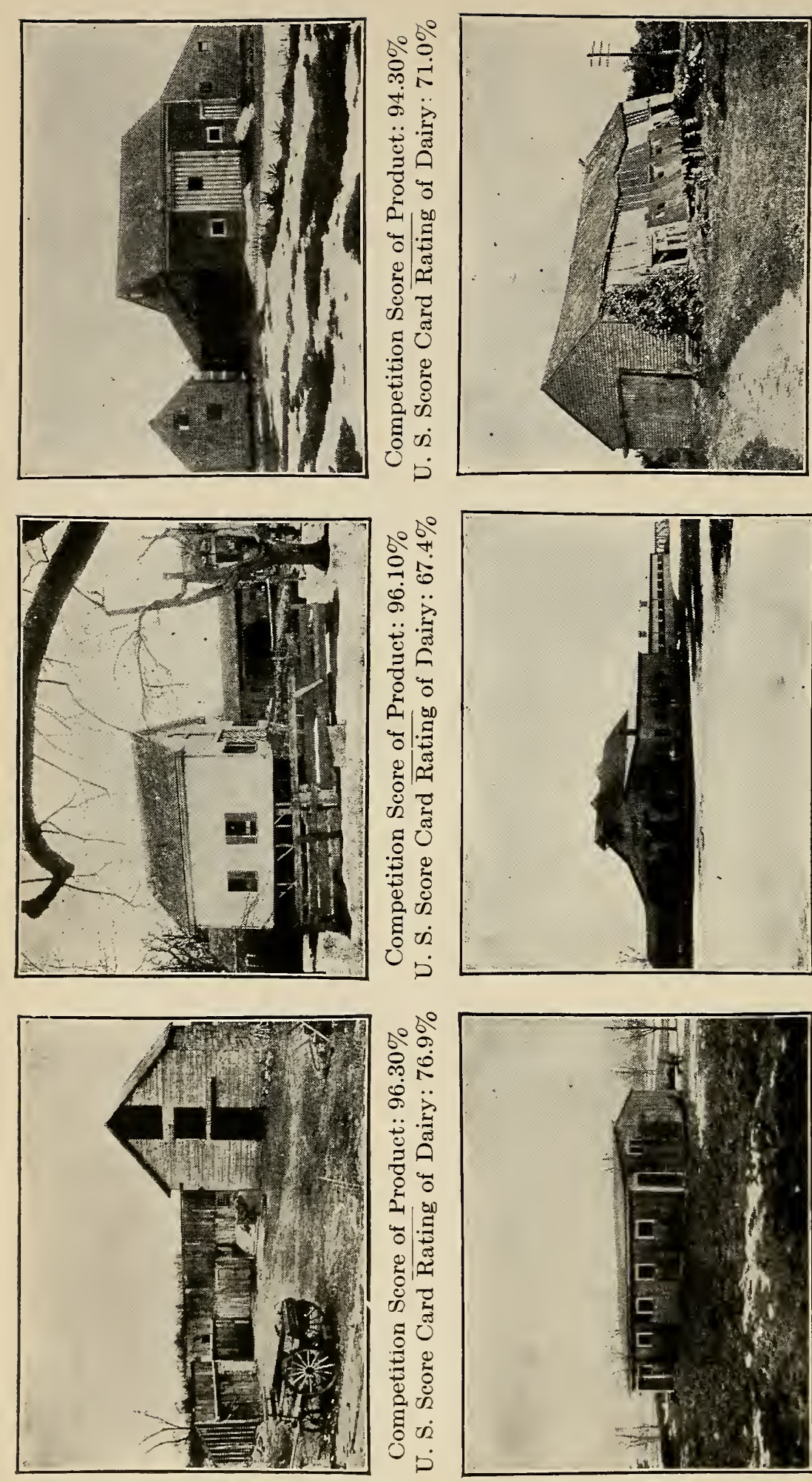

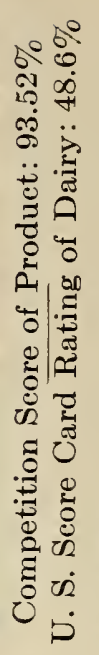

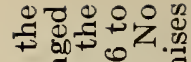
大 कि की

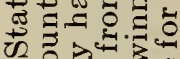
०. 0 . ๘न . of . o.

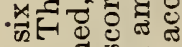

乙о

20

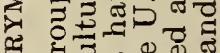
50.0.

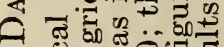
84 의 7 8 市 + .. 0 हू

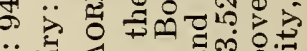

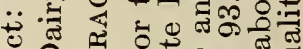
○ 엉 D 50 की ○. Z Z 유 ॠ 记

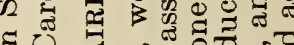

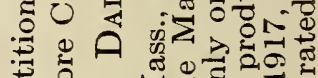
设 의

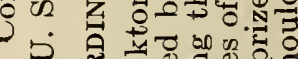

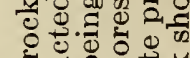

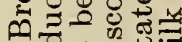
- bo कि مी คे 10 国.

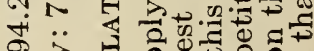
$\therefore$ 落 배 కด

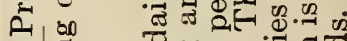
प.

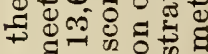
4 的

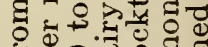
幽政

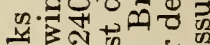
承N W

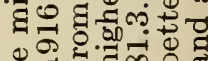
ه 웝. 
Finally, the newer ideas on sanitary milk production-the insistence on effective method as opposed to observance of arbitrary, unessential requirements,are steadily making their way into practice. Speaking of the fact that the conditions which are ordinarily observed by the dairy inspector bear no definite relation to the sanitary character of the milk itself, Dr. North says:-

The production of "Grade A Milk" for the New York City market in several thousand barns of the ordinary type by the rank and file of dairy farmers, such milk in most cases conforming with standards for bacteria of 25,000 , and even 10,000 , is a demonstration of this fact on a gigantic scale. ${ }^{13}$

\section{AMENDMENT OF THE DAIRY SCORE CARD}

We may now return to the question whether, in view of the knowledge now at hand of the really essential factors in clean milk production, the dairy score card can be satisfactorily amended.

Efforts have from time to time been made to correct the inadequacy of score cards by assigning more weight to methods than to equipment and by assigning a greater value than previously to certain of the methods. Even so, Harris has shown from the study of Brew which has already been cited that the two cards which gave 60 per cent to methods differed distinctly more in estimation of methods than in that of equipment, and that even when the score for methods alone was considered there was no distinct correlation with the bacterial counts. This leads Dr. Harris to remark that "the lower correlation of the values assigned for methods as compared with those for equipment is 
perhaps the most serious criticism to be made of the score cards."

The advocates of the score card believe that it can be adjusted so that it may still be useful as a means of dairy instruction, of guidance to the inspector or demonstrator, of education of the dairy farmer, and even of rating. An invaluable paper dealing with this question has recently been published by Dr. North. ${ }^{14}$ After discussing the compositions of well-known score cards, Dr. North takes up the relations of different items or factors to the actual character of milk as shown by bacteria counts, concluding with a suggested new type of card, in which 90 per cent of the score relates to the three great considerations: milking, cooling, and sterilizing. A division of items is also made between primary and secondary equipment and primary and secondary methods. This suggested card is, therefore, not merely a revision of present cards, but represents a radical change in arrangement and emphasis.

Dr. North's card, while not put forth as insusceptible of possible modification, undoubtedly approximates in its arithmetical degrees of emphasis the knowledge existing to-day on the relative weights of the various sanitary items. It therefore affords a hopeful affirmative answer to the question as to whether the score card can be satisfactorily amended. Although containing a large number of items relating to secondary or non-essential matters, thus negativing the idea of an exhaustive yet simple card, it will give both inspector and dairyman a very fair indication of the importance to be attached to the various points in milk 
production. The idea of scoring has become so well established and its effectiveness as a means of practical procedure so well proven that the move to put it on a thoroughly accurate basis is well worth while. Some such schedule is evidently desirable to prevent inspection or dairy demonstration from becoming a matter of the inspector's personal opinion and to answer the farmer's question as to how he can best attain the demanded result of low bacteria counts. Even where sufficient bacteriological testing is not available, such a card will furnish a valuable guide to dairy inspection and operation, although the accurate grading of milks requires such testing. A practical application of a card of this new type in connection with bacteria counts would readily determine its applicability and its degree of correlation with the bacterial results.

It must be borne in mind that the score card, useful as it may be, can give only approximate or probable indications. The ultimate criterion is the laboratory test. How, for example, shall we infer that a dairyman actually does always use the sterilized smallmouth pail or that he milks and cools properly, except by results as shown by regularly favorable tests? His statement may or may not be dependable, but the test is a telltale.* The logical mode of control is the valua-

* It is not here meant that the bacteriological laboratory can indicate the exact history of a milk or absolutely certify that the dairy methods are correct. Bacteria counts are subject to variations that are impossible to interpret without a knowledge of circumstances, and can only be taken as general summings-up. For this reason inspection can never be dispensed with, but must be considered as complementary to the laboratory. 
tion of milks according to laboratory tests, complemented by instruction of the dairyman in the simple methods by which he can keep his count down. The use of a rational score card would make such instruction definite and accurate, but his attention should be directed through the rating according to his equipment and stated methods to the desired final bacterial result.

While the part that has been played by the dairy score card in the past in stimulating milk supervision is not to be underrated, it must be said that the forms of the card accepted hitherto represent a phase of development in which practical exigency required action on assumptions now seen to be faulty. Now that such assumptions may be corrected a reasonably accurate score card may be formulated which will be of decided service. With the use of such a card there are probably few farmers who would fail to practice the indicated methods if the sale of their milk depended upon results.*

\section{INFANT WELFARE STATIONS}

Contemporaneous with the clean milk movement was the development of infants' milk depots, or milk stations, whose initial object was the dispensing, free or at cost, of a high-grade milk for infant feeding. The idea was the result of the conviction that the market milk of large cities was unfit for infant feeding, yet that the poor must have good milk at a low cost.

* No discussion can be entered into here regarding score cards for milk plants. Similar considerations, however, apply to such plants in that they should be judged, not merely by equipment and visible operation, but chiefly by their bacterial efficiency. 
The first institution of this kind in the United States was established at the Eastern Dispensary in New York, by Dr. Henry Koplik, in 1889. The establishment of the important Straus milk depots was begun, in New York, in 1893, and have since had a great influence in this field of endeavor. The Straus depots dispense milk of the highest grade, modified and pasteurized at the depot. Similar work is also carried on by the New York Milk Committee, the Health Department, and other organizations in New York City. The first municipal milk station was established in Rochester, N. Y., in 1897. Infants' milk depots have been established, under either unofficial or municipal control, in all the larger cities of the United States and in many of the smaller ones. ${ }^{15}$

Curiously enough, what was originally incidental to the infants' milk depot has become the chief function of the fully developed infant welfare station,-consultation and advice in the general hygiene of the infant. When the milk was modified it was found necessary to bring the baby to the depot for examination and prescription of the formula; hence the consultation class. The distribution of milk has now become subordinate to the encouragement of maternal feeding and of the general hygiene of the child; and even when artificial feeding is necessary, instruction in the methods of feeding and, in many cases, of home modification of milk is as essential as the milk itself. Dr. S. Josephine Baker of the New York City Department of Health has given the opinion that "the solution of the problem of infant mortality is 20 per cent pure milk and 80 per cent training of the mothers." Prenatal instruction, 
consultation, and the encouragement of breast-feeding are now the chief lines of the best milk-station work. In short, the doctor and the nurse, rather than milk supply (important as this is), are the chief force of the infant welfare station.

Milk stations have served, and do serve, an important purpose in providing at cost or less a special grade of milk for infant feeding. Countless babies have thriven through the efforts of these agencies when safe market milk could not be obtained except at a prohibitive cost, and when a poor grade of "loose" or store milk swarming with bacteria would often have been used. Such distribution of milk is not, however, a cure-all. Even in the districts where milk stations exist, many of the families most in need of good milk will rely on the ordinary market supplies. There are, moreover, the families of the middle classes, which may not get much better milk than the tenements, and which cannot afford certified milk, but which would not readily be drawn to milk stations even were they generally available.

One of the chief objects of adequate milk control is to bring into the general market, at a moderate price, a recognized grade of milk suitable for infant feeding. Such milk could be sold both from wagons and from strictly supervised stores, -in the latter case, perhaps, at a lower price. The accomplishment of this will be the complete attainment of a general object which is now attained only partly - though in regard to the most pressing need-through milk stations. The latter, on the other hand, will be freer to exercise the larger, more important educational function of the modern infant 
welfare station. With reliable infants' milk well recognized in the market, station distribution and home pasteurization would be largely unnecessary; the energies of the station nurses would then be concentrated, so far as milk is concerned, on teaching the home care and preparation of milk, while station preparation would still be possible if and where deemed necessary. It must be said, however, that at the present time milk stations are often the only thing that stands between the baby and the dangers of ordinary milk.

\section{LABORATORY TESTS AND STANDARDS}

\section{CHEMICAL}

The earliest milk standards adopted were chemical. Such standards relate to the general composition of milk, and inasmuch as this in nature varies very considerably, there has been no exact agreement in the standards set by various authorities. The United States official standard may be taken as representative: this requires 12 per cent total solids, 8.5 per cent solids not fat, and 3.25 per cent fat. A standard of 9.25 per cent total solids is prescribed for skimmed milk. Standards set by the various States and cities* vary somewhat from the above and may even establish separate figures for winter and for summer. It must not be thought that milk which is barely "standard" according to these figures is the ideal; they merely represent

* The U. S. Department of Agriculture has recently issued a summary of these. 
the minimum that the law allows.* Of the special figures, that for fat is subject to greater variation; the other solids are more constant. The fat percentage may be readily determined by the simple Babcock method.

It is important to note that chemical composition. is not a matter of sanitary quality but of nutriment. Nor is it the only factor in nutrition, for the character of the milk as to digestibility and minute composition, also enters into the question. Thus milk from Holstein cows, though thinner in fat than that from Jerseys and Guernseys, is believed to be more digestible because the fat globules are smaller; hence it may actually yield readier nutriment, and physicians often give it the preference for infant feeding.

That the proportion of fats and other components is not a sanitary but rather an economic question, does not, however, justify neglecting the consideration of chemical composition in attempting to solve the milk problem as a whole. It is certainly important to the consumer's pocketbook if not to his health that he get his money's worth in nutriment-that he pay according to the foodstuffs he is actually getting. Manufacturers of butter, cheese, and other milk products customarily recognize this principle when they buy milk and cream on a butter-fat basis. With market milk, as with many other food products, it is simply a question of right labelling, to which we shall revert in a later chapter.

Objection has been raised against legal standards

* Distinction must be made between naturally substandard milk and milk adulterated by watering or skimming. Much heavier penalties are usually, and justly, prescribed for adulteration. 
for composition, largely on account of the natural variations in milk from individual cows. (See Fig. 1, Chapter I.) Such cows not infrequently give milk which fails to comply with official minima. Small herds may sometimes give such milk. The objection has been strengthened by the failure of authorities to agree on any precise standard. Sometimes the standards have been altered in an attempt at adjustment. In New York State, for example, the dairy farmers came to produce so largely with cows bred for quantity but not for richness that the Legislature lowered the total solids requirement from 12 to 11.5 per cent. Dealers may have to mix milks and creams so as to meet a standard to which all the milk bought by them does not attain. The tendency, especially in the case of the large supplies, is to bring all milks down to a level just above the legal minimum. Where the producer has a rich milk there is temptation to skim, or even to water when the authorities are not vigilant. It is obvious that such a levelling-down of milks is an artificially induced condition which operates to drive the richer milks from the retail market. This makes it more difficult for the consumer who desires the richer kinds to obtain them.

In view of such considerations it has been proposed to abolish the legal standard and permit milks to be sold on their merits. This was suggested as long ago as 1907, by Mr. P. M. Harwood, Chief of the Massachusetts Dairy Bureau, in a paper entitled "Has the milk standard outlived its usefulness?" 16 The commission on Milk Standards of the New York Milk Committee has now suggested the regulation of market 
milk on the basis of guaranteed percentage composition, as follows:-

1. Sellers of milk should be permitted choice of one of two systems in handling market milk. Milk can be sold, first, under the regular standard, or, second, under a guaranteed statement of composition.

2. Any normal milk may be sold if its per cent of fat is stated. In case the per cent of fat is not stated, the sale will be regarded as a violation unless the milk contains at least 3.25 per cent of milk fat.

3. As a further protection to consumers, it is desirable that when the guaranty system is used there be also a minimum guaranty of milk solids not fat of not less than 8.5 per cent.

4. Dealers electing to sell milk under the guaranty system should be required to state conspicuously the guaranty on all containers in which such milk is handled by the dealer or delivered to the consumer.

5. The sale of milk on a guaranty system should be by special permission obtained from some proper local authority. ${ }^{17}$

The application of this idea of fat markings will be reverted to in Chapter V.

\section{BACTERIOLOGICAL}

The total count of bacteria per cubic centimeter * has commonly been accepted as the most satisfactory single index of the sanitary quality of milk. This figure represents in sum the bacterial content resulting from

* Attention has recently been called by Robert S. Breed (Science, Nov. 24, 1916) to the fact that the customary form of expressionnumber of "bacteria per cubic centimeter"-is incorrect inasmuch as "these counts are probably counts of groups of bacteria rather than of 



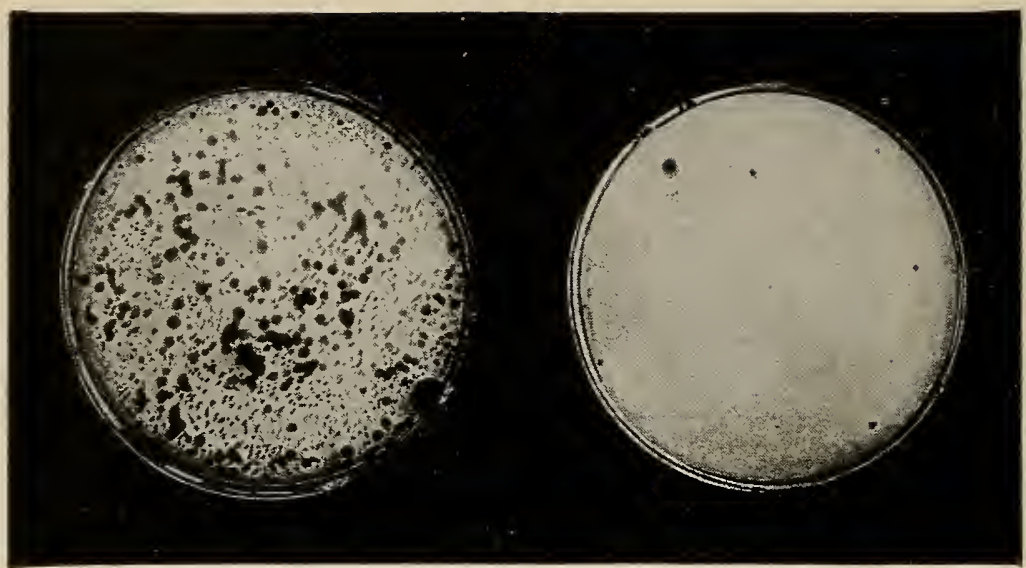

Plate 4. (a) Bacteria Plates

High- and low-bacteria milks. The spots are bacterial colonies each of which has developed, in the jelly-like medium, from a bacterium or group of bacteria in a minute amount of the milk. Bacteria "counts" indicate the numbers of colonies developing from precisely measured quantities of milk, reduced to a basis of "bacteria per cubic centimeter." (Courtesy of the New York Milk Committee and Dr. Chas. E. North.)

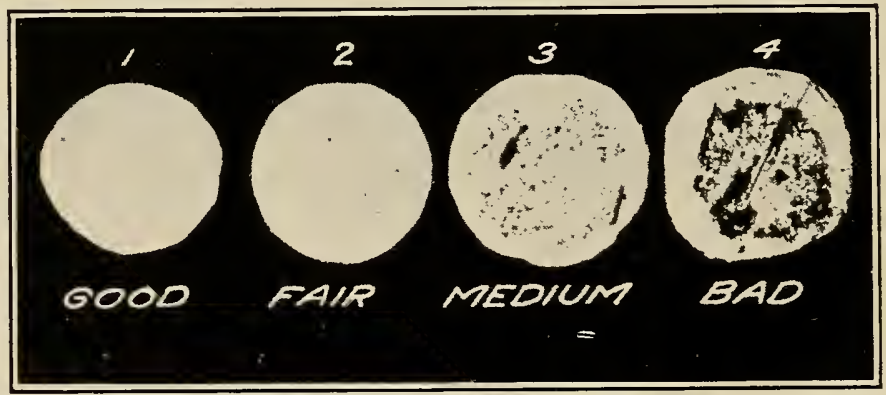

\section{(b) Dirt Tests}

Dirt strained out of four kinds of milk by use of small cotton disks. The dirt is mostly manure and contains great numbers of bacteria. Such manure may contain the germs of bovine tuberculosis. This is a ready practical method of demonstrating the results of dirty or careless milking, though it cannot take the place of the far more searching tests of bacteriology. (Bull. 361, U. S. Dept. of Agriculture.) 
contamination and from later development of the contaminating bacteria. The total count does not, however, give any information as to the kind of bacteria present. Pathogenic organisms are not detected. Nor is it possible, by this test alone, to determine how far the count is due to contamination and how far to multiplication of the bacteria through insufficient refrigeration. The count depends, as a rule, far more on such multiplication than on the initial contamination. Pasteurization, moreover, destroys the value of the total count as an indicator of the previous state of the milk. The question may be asked, what means we have of determining the presence of contaminating matter or of disease germs in milk. The routine detection of specific disease germs in milk is impracticable because of difficulties of bacteriological technique, and their presence, even if detected, would not be known until after the milk had been distributed and consumed. The estimation of dirt or filth contamination is, however, feasible. The tests for this purpose will be discussed in the following section.

Notwithstanding what has just been said, the total count, taken as a general index of contamination plus

individual bacteria and ... are probably always lower than they should be because of the fact that not all bacteria will grow on nutrient agar at the incubation temperature used." While this qualification is well recognized by bacteriologists, there is danger of its being neglected even by them. Microscopical studies are cited by Mr. Breed to indicate that the actual numbers of (living?) bacteria in market milk are from one and a half to twenty-five or more times the number of colonies developing, depending on the kinds present. Until, however, some other form of statement is adopted, the number of "bacteria per c.c.," i. e., of plate colonies, remains the practical basis of comparison of the general bacterial character of different samples of milk. 
bacterial fermentation or decomposition, has an accepted value together with the merit of simplicity in routine milk examination.*

Standards $\dagger$ for total count of bacteria have been adopted by many municipalities; in fact such a standard-or rather, maximum for market milk-has been considered the necessary basis for administrative use of the counts. The first bacteriological standard in the United States was adopted by the New York City Board of Health, which in 1900 set a limit of $1,000,000$ bacteria per cubic centimeter, which, however, it was found at that time impossible to enforce. Boston adopted in 1905 a legal limit of 500,000 , the figure which is still its standard for all market milk. The United States Public Health Service ${ }^{18}$ has ascertained the limits which have been established by some 150 cities of 10,000 population or over. These range from

* An important study of the technique of the bacteriological determination of the total count, based on a co-operative test by four of the large laboratories in New York City, has recently been published. (Conn, H. W., "Standards for determining the purity of milk: the limit of error in bacteriological milk analyses," Reprint 295 from Public Health Reports, Aug. 13, 1915.)

This paper finds defects in technique under present standard methods but concludes that these methods are sufficiently accurate to warrant the grades recommended by the Commission on Milk Standards (Appendix B). In routine bacteriological milk analyses the Standard Methods of the American Public Health Association, as amended from time to time should be exactly followed. A new report by the Committee on these methods was presented at the 1916 meeting of the Association and a revised edition of the Methods has been published.

$\dagger$ This use of the term "standard" is unfortunate in that it implies an average acceptable quality if not something better. Exactly standard milk would, of course, be barely within the limit of the law and hence of the poorest salable quality. "Legal limit" is a better term. 
100,000 to 500,000 for market milk in general, but a number have different requirements for raw and for pasteurized milk and, where grading has been adopted, for more than single grades of these. Some cities have established separate standards for summer and winter, on the principle that lower counts can be obtained in the colder months.

Marked improvements have been brought about through bacterial standards even where rigid enforcement has not been obtained. In the large cities the number of bacteria in many supplies in the summer months has been so great that their reduction to below the standard was not to be accomplished at a stroke. In the smaller places the low germ-content has been more attainable. The town of Montclair, N. J., for instance, which has for years followed the clean milk ideal, has succeeded by vigorous measures in obtaining milk supplies of which 85 per cent of the samples run below 100,000 bacteria per cubic centimeter.

For example of bacterial limits for different grades of milk, see the classification of milk; Appendix B.

It is worthy of note that the Commission on Milk Standards appointed by the New York Milk Committee gave special consideration to bacterial standards and, with regard to its recommendations, reported:-

The Commission believes that the adoption and enforcement of these bacterial standards will be more effective than any other one thing in improving the sanitary character of public milk supplies. The enforcement of these standards can be carried out only by the regular and frequent laboratory examinations of milks for the numbers of bacteria they may contain. ${ }^{19}$ 


\section{Microscopic Examination}

Microscopic examination of milk for the determination of pus and bacteria has been coming in recent years somewhat rapidly into use, but is not fully established as a standard method of estimating numbers of bacteria. It is now under consideration by a special subcommittee of the National Commission on Milk Standards and will be reported upon later.* The following comment, from the paper by Dr. Conn already referred to, is meanwhile of interest:-

The direct microscopical examination of milk smears by the Breed method will classify raw milk into grades A, B, and $\mathrm{C}$ with about the same accuracy and much more quickly than the plate method of bacteriological analysis will do. It is of no use in the study of pasteurized milk, however, since it discloses dead as well as living bacteria, no method of distinguishing between them having yet been perfected. It might be of value in telling whether such milk had become old before it was pasteurized, since such would show large numbers of dead bacteria by the microscopic method, though it might show small numbers by the plate method.

The direct microscopical method of bacteriological analysis . . . may be of great aid to the large dealer to enable him to determine promptly whether he is purchasing milk of $\mathrm{A}, \mathrm{B}$, or $\mathrm{C}$ grade. The possibility of quick results and

* It is, however, discussed in a recent provisional report of the Committee on Standard Methods of Bacteriological Analysis of Milk, of the Laboratory Section of the American Public Health Association (Am. Jour. Public Health, Dec., 1916). While the method is not as yet recommended by the Committee as a standard method of estimating numbers of bacteria, its value in rapidly dividing raw milk into grades and in detecting large numbers of streptococci is recognized. 
ease of making the smears at the dairy or shipping station, subsequently sending them to the laboratory for microscopic examination, renders the method especially applicable at the dairy end of the line. ${ }^{20}$

\section{CONTAMINATION TESTS}

We have already referred to the value of being able to determine the presence of dirt and filth, particularly manural pollution, in milk. Concerning the present status of tests for such contamination we cannot do better than to quote at some length from a paper of Dr. John Weinzirl:-

This problem [of eliminating dirt from milk] resolves itself into two distinct phases: first, the problem of finding the most suitable method of detecting dirt in milk; secondly, bringing the evidence home to the dairyman and making him respond to the new demands. Let us first consider the methods of detecting filth in milk.

Three methods are in use more or less commonly, viz.: (1) Determining the total number of bacteria present in the milk, assuming this to be an index of its cleanliness, and fixing a line beyond which the count may not go, otherwise sale is forbidden. (2) Determining the number of B. coli present and setting a similar standard. (3) Determining visible dirt, and again making a standard for purity. To these the writer now desires to add another, (4) Determining B. sporogenes and creating a standard of purity.

It is well known that the total count depends upon other factors as well as upon dirt, for time and temperature may cause a high count in an otherwise clean milk; doubtless such milk should be barred from sale, but it does not reach the real question, which is, the amount of dirt present in it. Again, if the milk is pasteurized, the total count fails utterly . 
to indicate dirt.* Since the use of pasteurized milk is rapidly increasing, the ultimate failure of the total count is obvious. As to determining the number of $\mathrm{B}$. coli and using the data to indicate manure, this method will fail for the same reasons that the total count must fail. In addition, the determination of B. coli requires rather too elaborate a technique to make it generally available. Up to the present time the method appears to have gained little favor. When the test is made sufficiently early and before the milk is pasteurized it has been shown $\uparrow$ that the method is an excellent one for the purpose. The dairy in which the method was applied received its supply from a comparatively limited area and from only twenty dairymen. Special endeavors were made to produce only superior milk.

At present the determination of visible dirt appears to be in greatest favor and has proven itself a valuable asset to the sanitarian in checking up supplies. The ease with which the determination is made and the tell-tale nature of the evidence presented speak highly in its favor. The Wizard Sediment Tester $\ddagger$ has proved very satisfactory in our hands. Indeed the method leaves little to be desired so long as the producer does not become wise and adopt clarification methods such as heavier strainers or 'centrifugation. Obviously the method will fail as soon as better clarification methods are adopted. Such clarification cannot lessen the number of manurial bacteria in milk or the soluble portion of the manure, but rather aids in their better distribution. From these considerations it is quite clear that we have no method for determining manurial pollution which does not fail at some critical point. The total count and B. coli determinations fail in milk that has been held for some time or has

* Except in that samples taken before pasteurization indicate general sanitary quality.-J. S. M.

$\dagger$ Weinzirl, John, and Felder, H. A., unpublished data.

$\ddagger$ The Creamery Package Mfg. Co., Chicago, Ill. 
been pasteurized, and the sediment test fails af er clarification.

To overcome these difficulties is the purpose of the B. sporogenes determination as an indicator of manurial pollution as proposed by Weinzirl and Veldee.* B. sporogenes is an intestinal organism, and hence indicates manure when found in milk; it does not multiply at ordinary temperature at which milk is held, and so it truly indicates the pollution even of milks kept for varying periods of time and at varying temperatures; it produces spores but these are not killed by pasteurization; and, finally, the organism can be easily and quickly determined. ${ }^{21}$

Thus far most of the work of health authorities on the dirt question has been concerned with visible dirt as disclosed by the sediment tester. $\dagger$ (See Plate 4.) The method is simple and is effective for demonstrational purposes. Its weakness, on the other hand, has been pointed out above. The B. sporogenes test is already known in water bacteriology, and its development in relation to milk is to be viewed with interest.

Dirt, or Sediment, Tests and Bacteria Counts.-To avoid possible confusion it is well to note that, as implied by Weinzirl and shown by recent experiments, ${ }^{22} \ddagger$ the quantity of sediment or visible dirt caught on the disk by the straining tests is no criterion of the bacteria count of the milk. High-bacteria milks may by these

* Am. Jour. Public Health, 1915, Vol. V, p. 862.

$\dagger$ There are several varieties of these. The New York City Health Department requires the test to be applied in all creameries shipping milk to the city, and has established a standard for use in determining whether milk contains excessive dirt. (Regulations, March 30, 1915.)

$\ddagger$ In these experiments (in the U.S. Department of Agriculture) the Lorenz apparatus was found the most convenient and practical. 
tests be shown "good," and low-bacteria milks "bad." This may readily be understood, for the bacterial flora depends not merely upon the amount of dirt contamination but also-and much more largely-upon the kind of contamination, the age of the milk, and the temperature at which it has been kept. Hence the dirt tests can throw light on but one item in milk sanitation-viz., the amount of sediment in unstrained milk (previous straining or clarification practically destroying the value of the tests)-and are far from being a general criterion of the conditions of production and handling.

\section{THE TUBERCULIN TEST}

One of the noteworthy discoveries of modern sanitary science is that bovine tuberculosis may be transmitted to human beings through the medium of cow's milk. ${ }^{*}$ At the same time a test-namely, the tuberculin test $\uparrow$-has been perfected by which tuberculosis can be determined in that important class of cows which are infected yet show no physical symptoms. This adds to veterinary examination an exceedingly valuable diagnostic agent.

The tuberculin test appears to have been first required, in addition to physical examination, by the

* This matter, with some reference to the amount of human tuberculosis of bovine origin, was touched upon in Chapter I.

$\dagger$ The test consists essentially in the hypodermic injection of an emulsion of killed bovine tubercle bacilli (tuberculin). Animals infected with tuberculosis react by a marked rise in temperature. This reaction has been accepted in the courts, as well as in veterinary medicine, as a thoroughly reliable test of a very high degree of accuracy when competently applied. 
Board of Health of Montclair, N. J., in 1907, which specified that the milk from reacting cows should be excluded from the local milk supply. The test was opposed by a large dairy company and the case was contested through the courts until a complete victory was won by the Board of Health. The decision has been supported in other cases, so that the legal status of the test is now secure.

The amount of tuberculosis among cattle varies. Some idea of the relative numbers of reactors which may be found by the tuberculin test may be had from the experience of Montclair when its ordinance went into effect in 1907:-

Of the New Jersey cows that had not been previously tested, 25 per cent reacted. Many of the figures that are available on the subject . . relate to suspected or picked herds, whereas the percentage of reactions above mentioned represents conditions of herds taken practically at random over a considerable area, with the exceptions that they had more than the average veterinary inspection, and that they had been stabled under good conditions. ${ }^{23}$

In individual herds as many as a half or even threequarters of the animals may react. The suppression of bovine tuberculosis by scientific methods is, apart from milk sanitation, an important object of animal husbandry.

In the elimination of tuberculosis from dairy herds a serious economic question arises. Drastic measures will result in a great diminution in the herds, a large financial loss to the dairymen, and a corresponding lessening in the milk supply with a resultant increase 
in the cost of the product. Elimination has, on the other hand, been encouraged in some States by legal reimbursement of the owner for a large part of the loss due to the slaughter of tuberculous cattle. However the loss may be met, it is a real one and means, directly or indirectly, a higher cost of the milk. It is natural to expect that this increase in cost will be reflected in the retail price, perhaps to the extent of a half-cent a quart, though it may be partly met through payments out of public funds to the dairyman in consideration of his loss through slaughtered cattle.

State regulation for the official testing and certification or condemnation of cattle obtains in certain States. It does not, however, evien where adequate, advantage neighboring States, but tends to make them, unless their own or Federal regulation intervene, a dumping ground for condemned animals. Fraud, too, is possible in that a positive tuberculin reaction can be prevented by covertly injecting the animals with tuberculin shortly before test and thus passing off such "plugged" cattle as sound.

If milk is to be consumed raw, it can be adequately protected from bovine tuberculosis only by requiring the tuberculin test as well as the physical examination of cows. But fortunately, as will be shown directly, there is a practical alternative in the process of pasteurization, which, moreover, saves the economic value of the cattle.

\section{PASTEURIZATION}

Thus far we have considered measures developed under the clean milk ideal; we now take up a remedy 
which, without dispensing from other precautions, cancels dangers which, practically, cannot be otherwise dealt with.

In a general way the dangers of raw milk have long been recognized. The European domestic custom for centuries has been to heat milk before use,- - the result of the experience that uncooked milk, like uncooked meat, was dangerous. This is still to a great extent the custom, although since the time of Pasteur his method of heating milk only to a temperature sufficient to destroy the great majority of the germs present has been looked upon with increasing favor, principally because in this way the "cooked" flavor of boiled milk may be avoided. But in the United States that tradition did not hold, and the consumption of raw milk has been the rule: it has required scientific propaganda and official action to bring pasteurization up to its present level of favor.

The term "pasteurization" has been used in a variety of meanings more or less approaching the original method of Pasteur. Through inaccuracy the process has not infrequently been misrepresented. It is essential that an exact scientific definition be recognized. Such a definition, applied to milk, has been framed by the Commission on Milk Standards *:-

That pasteurization of milk should be between the limits of $140^{\circ} \mathrm{F}$. and $155^{\circ} \mathrm{F}$. At $140^{\circ} \mathrm{F}$. the minimum exposure should be 20 minutes. For every degree above $140^{\circ} \mathrm{F}$. the

* The Commission on Milk Standards of the New York Milk Committee is, in its personnel and scope, virtually a national commission, and is of ten so called. It will be referred to in these pages by its short title. 
Fig. 12. Time and Temperature for Milk Pasteurization

It is to be noted that the pathogenic bacteria are killed at temperatures and times below those at which the physical and chemical constituents of the milk are affected. The neutral zone between these two sets of phenomena permits considerable latitude in the choice of the pasteurization conditions. (Report of Commission on Milk Standards, N. Y. Milk Committee, 1913.) of the bacteria in milk without actually sterilizing it. Among the organisms destroyed are those of typhoid fever, diphtheria, scarlet fever, tuberculosis, septic sore

time may be reduced by 1 minute. In no case should the exposure be for less than 5 minutes.

In order to allow a margin of safety under commercial conditions the commission recommends that the minimum temperature during the period of holding should be made $145^{\circ} \mathrm{F}$. and the holding time $30 \mathrm{~min}$ utes. Pasteurizing in bulk when properly carried out has proven satisfactory, but pasteurization in the final container is preferable.

It is the sense of the commission that pasteurization in the final container should be encouraged. ${ }^{24}$

The effect of proper pasteurization, as above defined, is to kill the vast majority

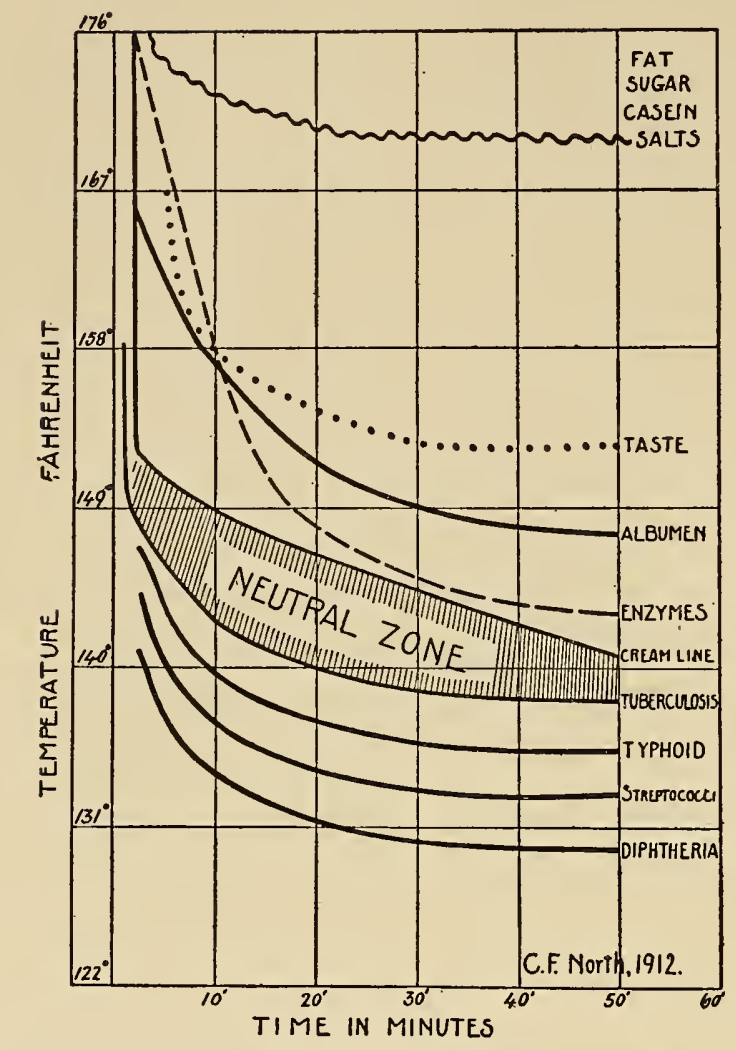


throat-in fact, of all the common milk-borne diseases. Moreover, through the destruction of miscellaneous bacteria and their toxins the milk is rendered a safer-often far safer-food for infants, young children, and invalids, with the result of a corresponding reduction in gastrointestinal disorders and an increase in vital resistance to other diseases. A number of authorities might be cited on this point. Dr. W. H. Park concluded from researches which have been quoted in Chapter I that "mother's milk is the best milk for a baby and pasteurized milk is the next best."

Proper pasteurization does not affect the flavor, odor, appearance, or cream line of milk, materially alter its chemical components, nor diminish its digestibility or nutritiousness.

At the same time, the process is not a cure-all for milk evils and, as Rosenau remarks, should never be used as a redemption process for bad milk. Its proper use is, in the phrase of S. H. Ayers, not to try to make a dirty milk a clean milk, but to make a clean milk a safe milk.

From the facts cited the following conclusions are to be drawn:-

Proper pasteurization of milk supplies under official supervision (with safeguard of the pasteurized product) is the only absolute insurance against milk-borne infection.

Through the general bacterial reduction effected it renders the milk a safer-often a far safer-food for infant feeding.

While it should not be taken to dispense from necessary supervision of supplies both before and after the process, it affords an insurance unattainable by inspection, medical and veterinary examinations, and laboratory analysis alone, however searching these may be. 


\section{RAW OR PASTEURIZED MILK WHICH IS THE SAFER?}

You insure your life against the time when accident or sickness may occur.

You buy safe milk against the time when other milk may spread disease.

Because you have been fortunate in keeping well does not mean that you do not need safe milk right now.

One man delivered milk for 30 years and his customers were safe until an epidemic of typhoid fever was traced to his supply and 295 of his customers were made sick and 10 died. He delivered raw milk.

An epidemic of disease has never been traced to Perfectly Pasteurized Milk.

's Milk is Perfectly Pasteurized and is Pure-Clean-Safe.

The cheapest form of life insurance for yourself and family ——_ ' ' Milk.

___ _ 's method of Perfect Pasteurization does not change the taste of milk, nor alter its digestibility. It makes the milk Safe.

Safeguard the health of your family by using

- 'S PERFECTLY PASTEURIZED MILK "It costs you no more than unsafe milk"

A postal will bring one of our representatives to explain our methods and show you our plant in pictures.

Visit Our Milk Depots

Order of our drivers, write or telephone

Fig. 13. Commercial Appeal on Sanitary Grounds This newspaper advertisement emphasizing the value of pasteurization has a publicity power not attained by many health bulletins.

In 1907, Health Commissioner Lederle of New York City took the position that practically universal pasteurization must be insisted upon. In spite of conservatism and prejudice, expert sentiment has steadily grown to favor this view. The consensus of the best 
opinion is reflected by the Commission on Milk Standards, which has made the following unanimous recommendation:-

Pasteurization is necessary for all milk at all times, excepting Grade A, raw milk. The majority of the commissioners voted in favor of the pasteurization of all milk, including Grade A, raw milk. ${ }^{25}$ *

In view of the present status of the matter, it is scarcely necessary here to go into the details of the case for pasteurization, which have been abundantly set down elsewhere, ${ }^{26}$ nor to dwell on objections which have been disproved.

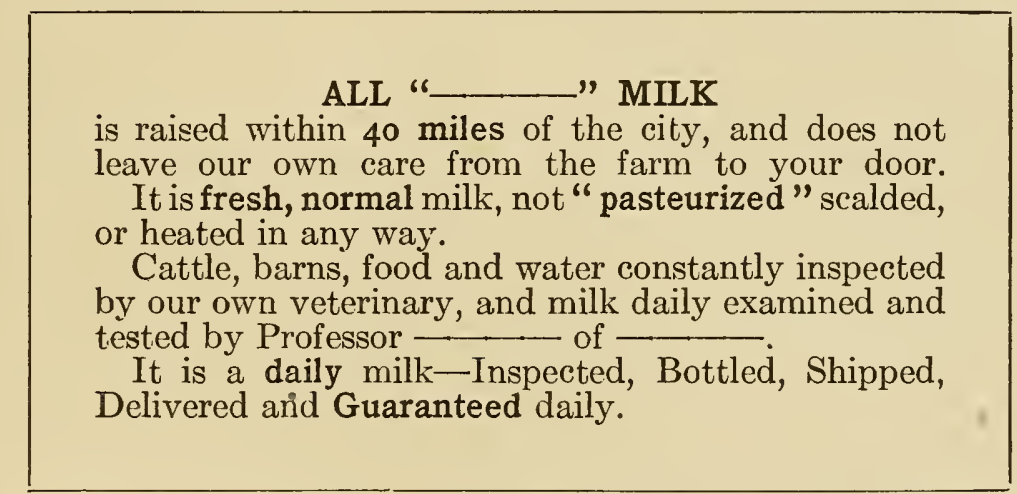

Fig. 14. Cominercial Appeal on Sanitary Grounds This firm, a rival of the foregoing, argues on a decidedly different basis. This milk might be guaranteed clean and fresh, but not necessarily free from infection, as was shown by an extensive epidemic of septic sore throat traced to the supply. The firm afterwards adopted pasteurization.

The matter of pasteurization is now one, not of theoretical debate, but of practical application.

Objections on dietetic grounds have been based upon

* Thę Commission's recommendations as to grades (see Appendix B) make pasteurization of Grade A milk optional. 
unproved assumptions and unsatisfactory evidence. The recent reported increase of cases of mild scurvy or similar nutritional disease among infants in New York City as a result of the greater use of pasteurized milk cannot, even if fully substantiated, justly be used as an argument against the process, the remedy being merely a little orange juice, or other antiscorbutic, in the diet of the infant. To give over a great means of safety on account of a minor disadvantage would be absurd. Special medical requirements may, if necessary, be met by permitting the sale of the highest grade of raw milk, as is recommended by the Commission on Milk Standards.

The pendulum of medical opinion appears now to be swinging in the direction of favoring even boiled milk. The scalding of milk as a domestic precaution previous to infant feeding and other uses has long been a common practice in certain European countries, and the American prejudice against the practice seems now to be dying out in the absence of dependable evidence regarding scurvy and rickets supposedly caused by heated milk. ${ }^{27}$

Other objections deal, not with the scientific process, but with possible abuses in its application; such objections should properly be taken merely as cautions. Thus, it is true that pasteurization and repasteurization may be used by unscrupulous dealers as a cloak for bad milk, that milk may be sold for pasteurized which has not been adequately treated, that the adoption of pasteurization ordinances does not necessarily mean their proper enforcement. But these are all simply questions of supervision. It is, of course, neces- 



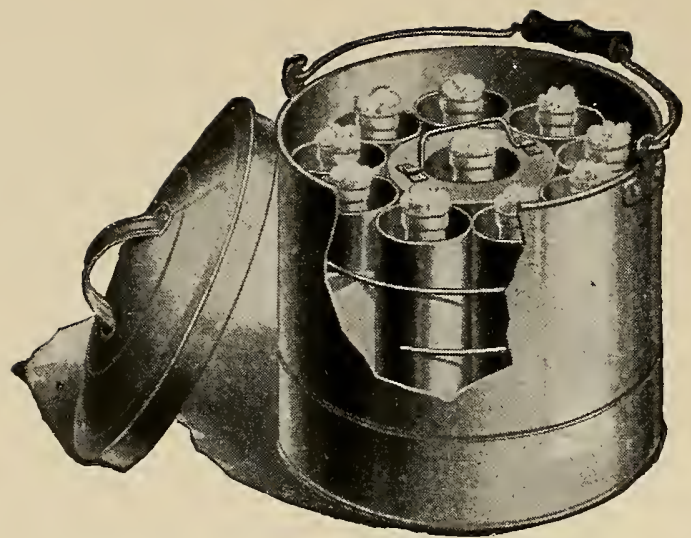

Plate 5. (a) Home Pasteurizer

When reliable pasteurized milk cannot be obtained, milk may be pasteurized in the home, for infant-feeding, by means of this apparatus, or even with ordinary kitchen utensils (see p. 109). A still readier means of safety is simply to heat the milk to boiling. Effective home heating ensures that no infection enter the household by medium of milk, and illustrates private prophylaxis as opposed to public prevention. The latter, however, affords general protection, while the private process, even when adopted, may be inefficiently performed. (Courtesy of the New York Milk Committee and Dr. Chas. E. North.)

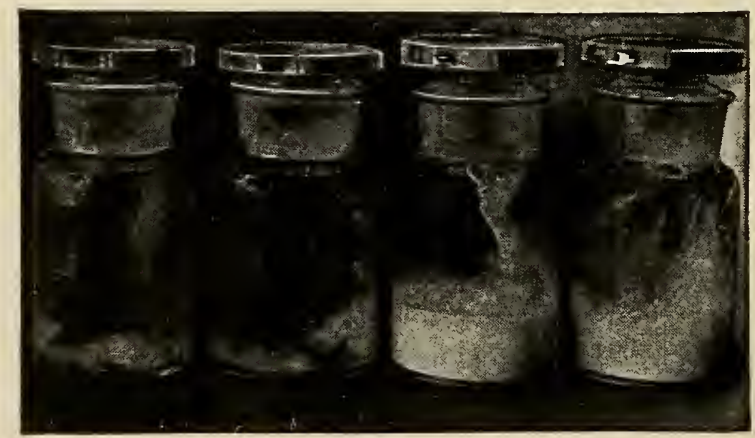

(b) Results of Clarification

The two bottles on the left show sediment and slime removed frcm milk of cows with normal udders, by the clarifier. The two bottles on the right show sediment and slime removed by the clarifier from the milk of two cows with sore udders, which caused a septic sore throat outbreak of 669 cases, with 14 deaths. (Courtesy of the New York Milk Committee and Dr. Chas. E. North.) 
sary not only to establish the proper definition of pasteurization but also to exercise adequate control of the commercial process * and supervision of the product both before and after, and this will require more extensive work than in the case of raw milk supplies. Such is the sum and substance of the opposition, once loud, now dying away, from uncompromising raw-milk advocates.

\section{Methods of Pasteurization}

Milk may be pasteurized in the home $\dagger$ or commercially. The latter way, under adequate supervision, is the more effective and economical. Various types of machinery for commercial pasteurization have been devised, of varying degrees of efficiency. ${ }^{28}$ What is called the "flash" method, by which the milk is kept heated for perhaps two minutes and then rapidly cooled, was formerly most in vogue, but has been superseded to a large extent by the "holding" method, which is much more reliable. (Plates 8,10 .) In this

* For specifications as to inspections, temperature records, and bacteriological tests, see 3d Report of the Commission on Milk Standards.

$\dagger$ The following practical method of home pasteurization of a onequart bottle of milk is given in the Health News of the New York State Department of Health for September, 1916. It is stated that this process ensures thorough pasteurization without undesirable changes. (It is well, when possible, to check such methods by use of a thermometer.)

"1. Boiling $2 \frac{1}{2}$ quarts of water in a large agate sauce-pan, or better

" 2 . Boiling 2 quarts of water in a 10 -pound tin lard pail, placing the slightly warmed bottle from ice chest in it, covering with a cloth and setting in a warm place. At the end of one hour the bottle of milk should be removed and chilled promptly. The water must be boiled in the container in which the pasteurization is to be done."

For a method of home pasteurization in infant's feeding bottles see Plate 5. 
process the milk is held at pasteurizing temperature for a longer time though at a lesser heat. Of the two methods only the latter complies with the definition which has been quoted. Even with this process there is a possibility that the milk may be contaminated through being run into unsterile containers, a danger which may be obviated by running the hot milk immediately into well-sterilized bottles or by pasteurizing in the final container. ${ }^{29}$ (Plate 14.) This last method, which is considered ideal, is now being tried under commercial conditions.

The proper care of pasteurized milk does not differ materially from that of raw milk, although there are biological reasons for taking somewhat greater care with the former. It has been shown, however, that properly pasteurized milk normally sours like raw milk; hence the supposed objection that pasteurization induces putrefaction does not hold. As Rosenau says, "the bugaboo that nature's danger signal is destroyed in pasteurized milk vanishes before the facts."

General Pasteurization the Insurance against a General Danger

The necessity for universal, or nearly universal, pasteurization which is now being urged more and more emphatically by the highest authorities arises from the fact that even with the greatest practicable precautions unpasteurized public milk supplies cannot, in the light of experience, be considered free from a greater or less element of danger.

Pasteurization is most obviously needed in the larger 


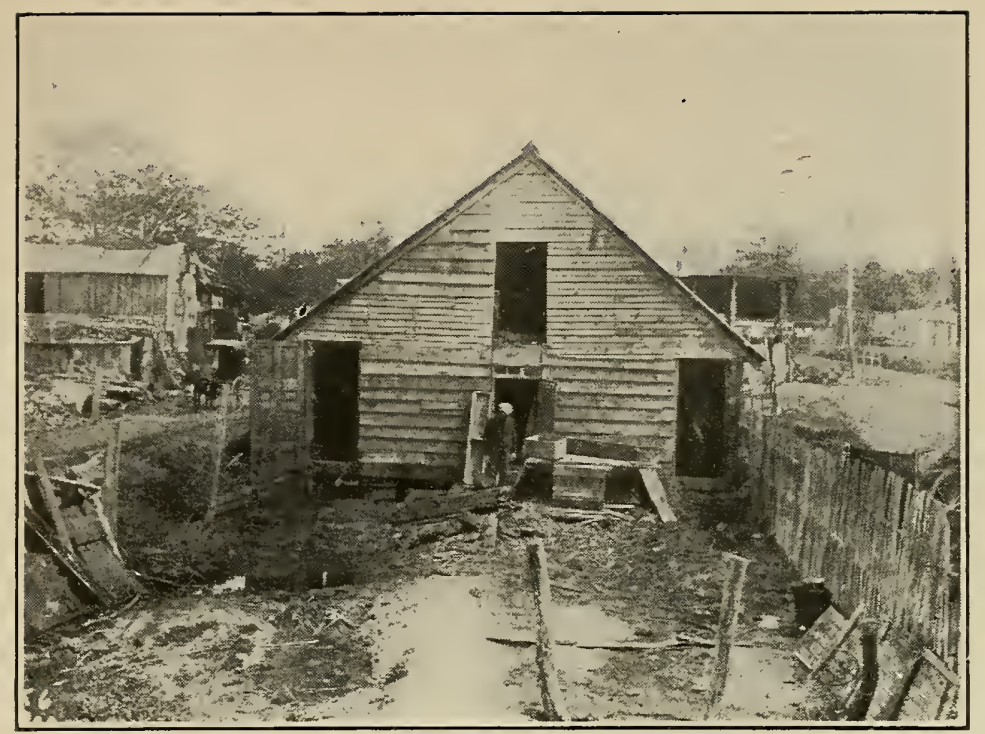

Plate 6. (a) Primitive Conditions in the Milk Industry

While it is the dairyman, not the dairy, which counts, the man who conducts his business under these conditions is not likely to pay much attention to essential sanitary methods in milking and handling milk. (Bull. 56, U. S. Hygienic Laboratory.)

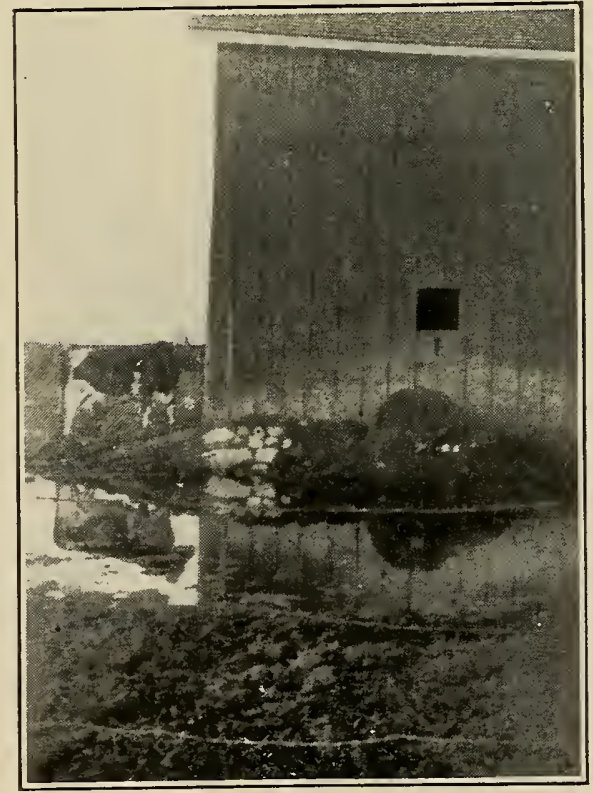

\section{(b) Insanitation Plus Waste on the Farm.}

Besides being contrary to decency and sanitation, this not uncommon condition means the waste of much liquid manure, one of the most valuable assets of the farm. (26th Annual Report, Bureau of Animal Industry, U. S. Dept. of Agriculture.) 


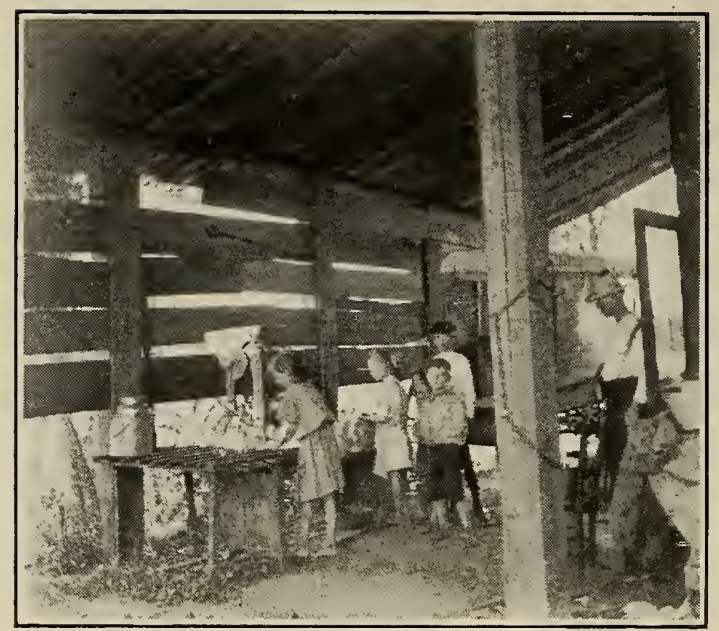

Plate 7. Primitive Conditions in the Milk Industry

Children entrusted with the important work of washing milk bottles, in a shed which is a mere apology for a dairy house. (Bull. 56, U. S. Hygienic Laboratory.)

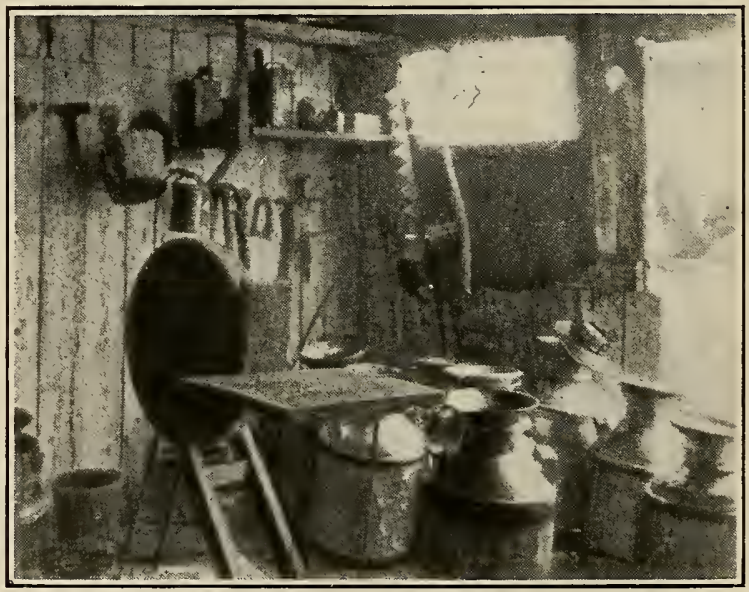

A milk house inviting dirt and rubbish and used as a repository for miscellaneous objects. (Bull. 56, U. S. Hygienic Laboratory.) 


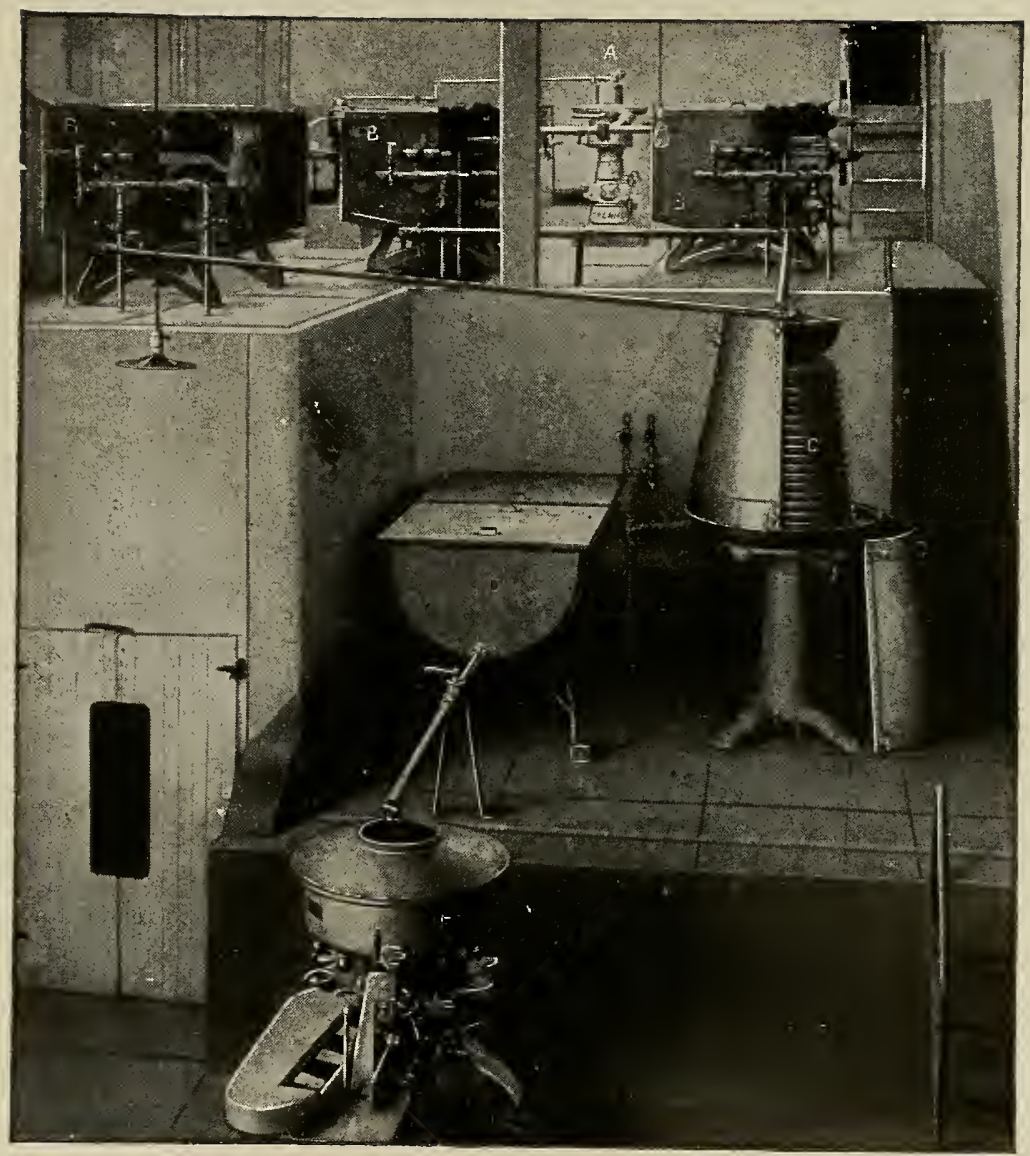

Plate 8. Advanced Conditions in the Milk Industry

Complete Modern Milk Plant, showing: (a) Milk Clarifier, (b) Heating and Holding Tanks, (c) Milk Cooler (covered type), (d) Storage Tank for Cold Milk, (e) Bottle-filling and Capping Machine. This picture assembles units such as are shown on a larger scale in Plates 9-11. (Courtesy of Dr. Chas. E. North and the New York Milk Committee.) 

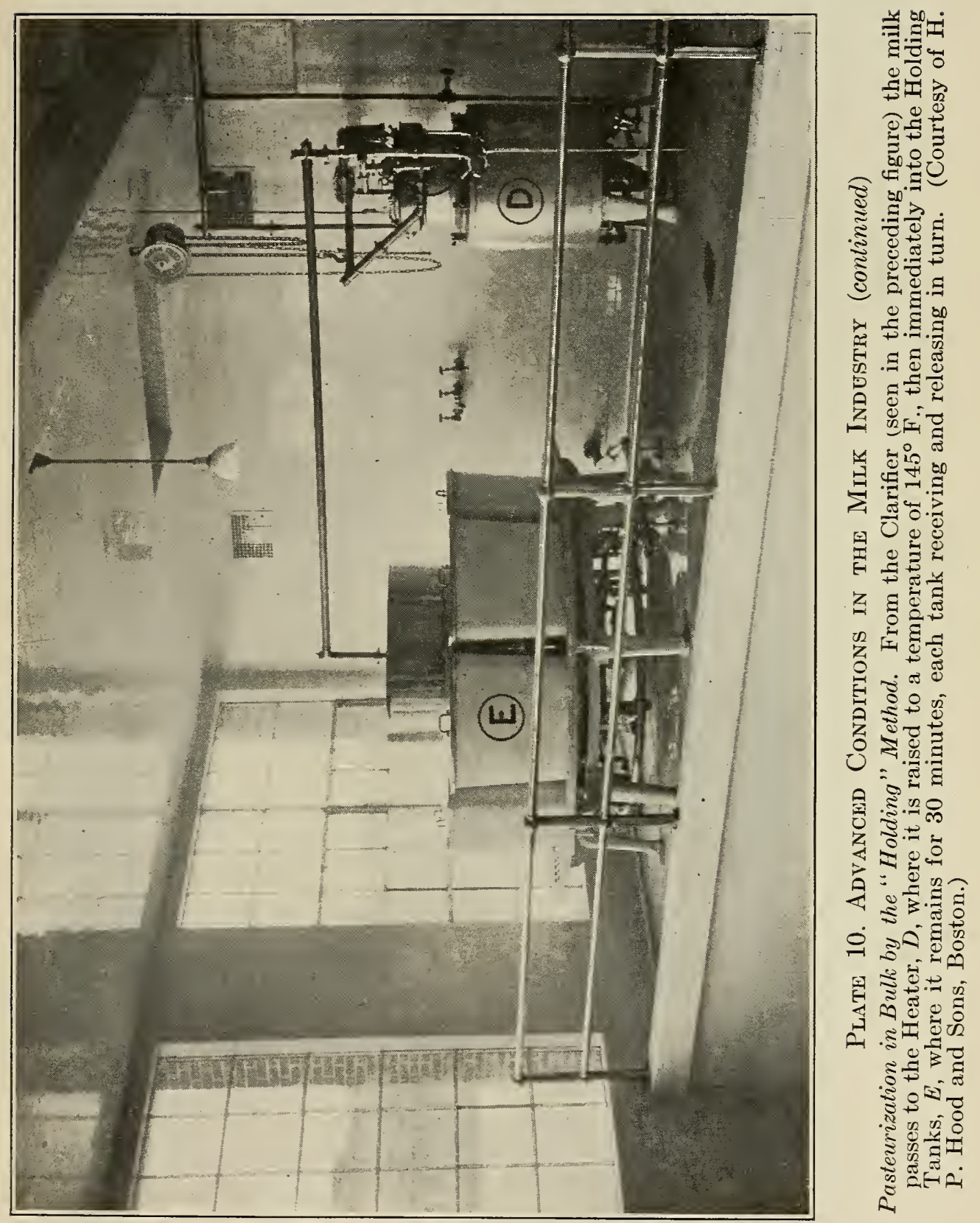


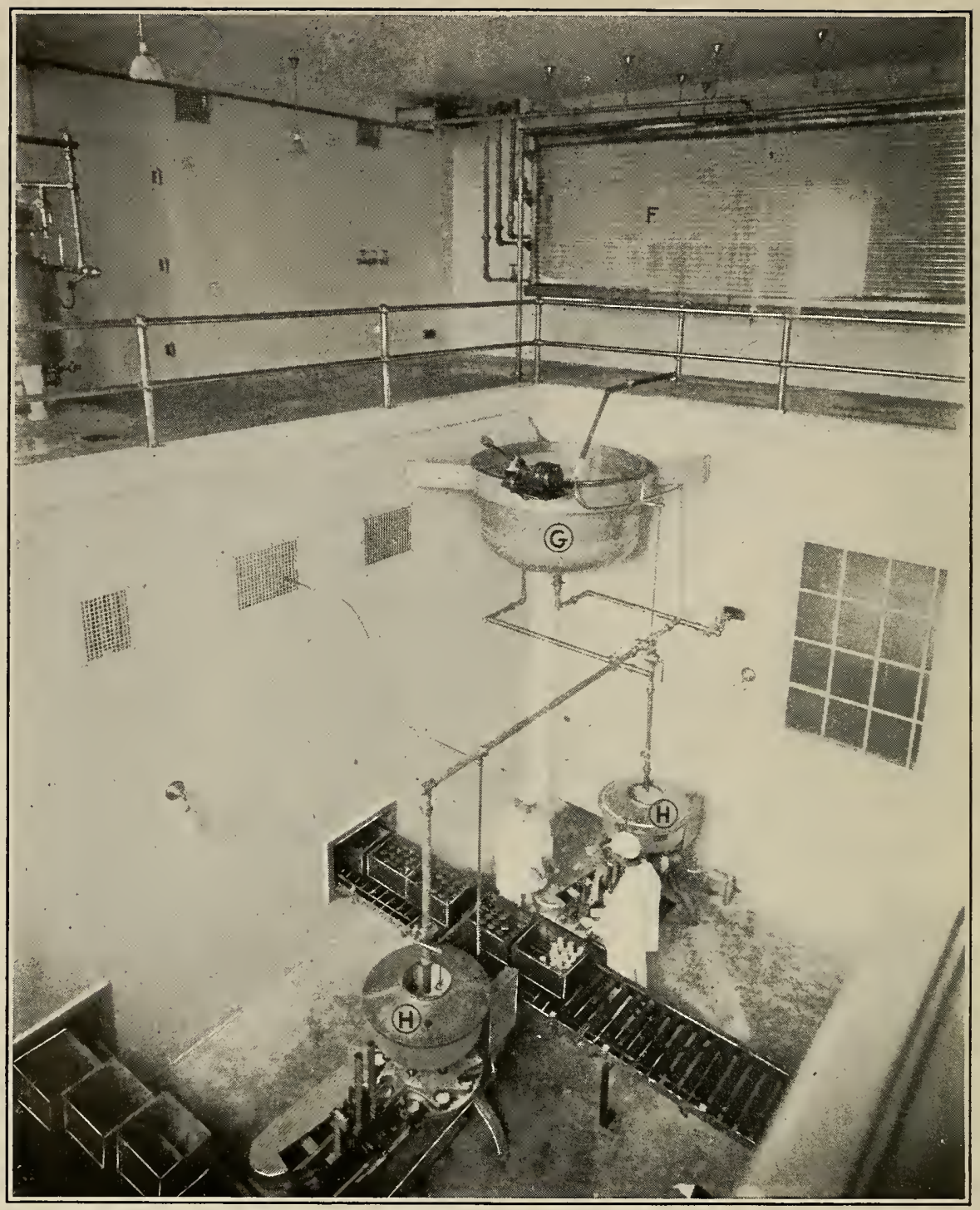

Plate 11. Advanced Conditions in the Mrlo Industry (continued)

Cooling and Bottling. After pasteurization the milk is run over the Cooler, $F$, which reduces it within 10 seconds to a temperature of $38^{\circ} \mathrm{F}$. A dustless atmosphere is essential to the protection of milk which is run over open coolers. It is also necessary that all apparatus and piping with which milk comes in contact be capable of being thoroughly cleansed and sterilized. After cooling, the milk passes to a vat, $G$, provided with me. chanical agitation, and thence to the rotary fillers $H H$, by which the bottles, previously sterilized, are mechanically filled and capped. This type of filler permits ready inspection of bottles. Employees medically examined weekly. (Courtesy of H. P. Hood and Sons, Boston.) 

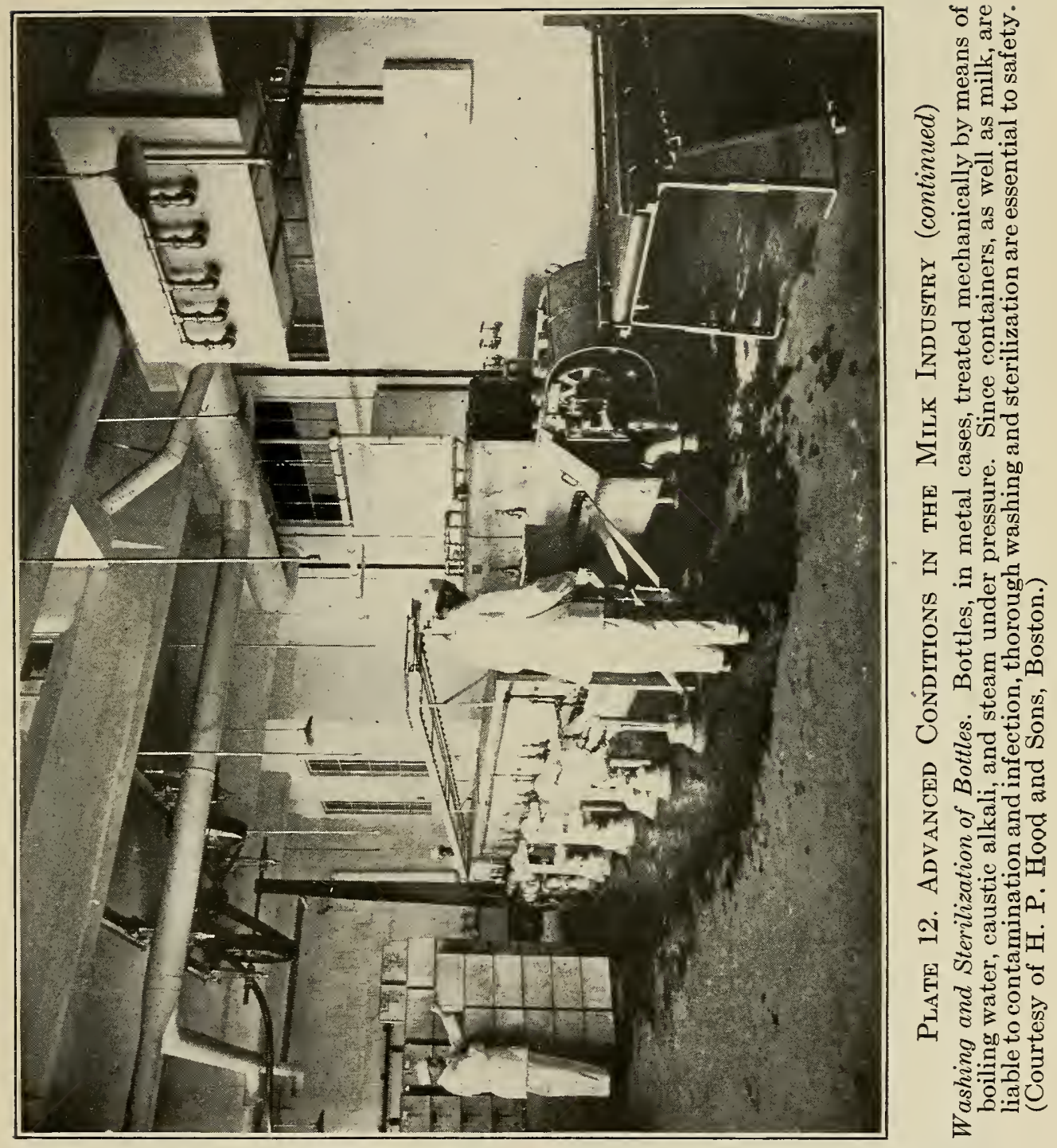

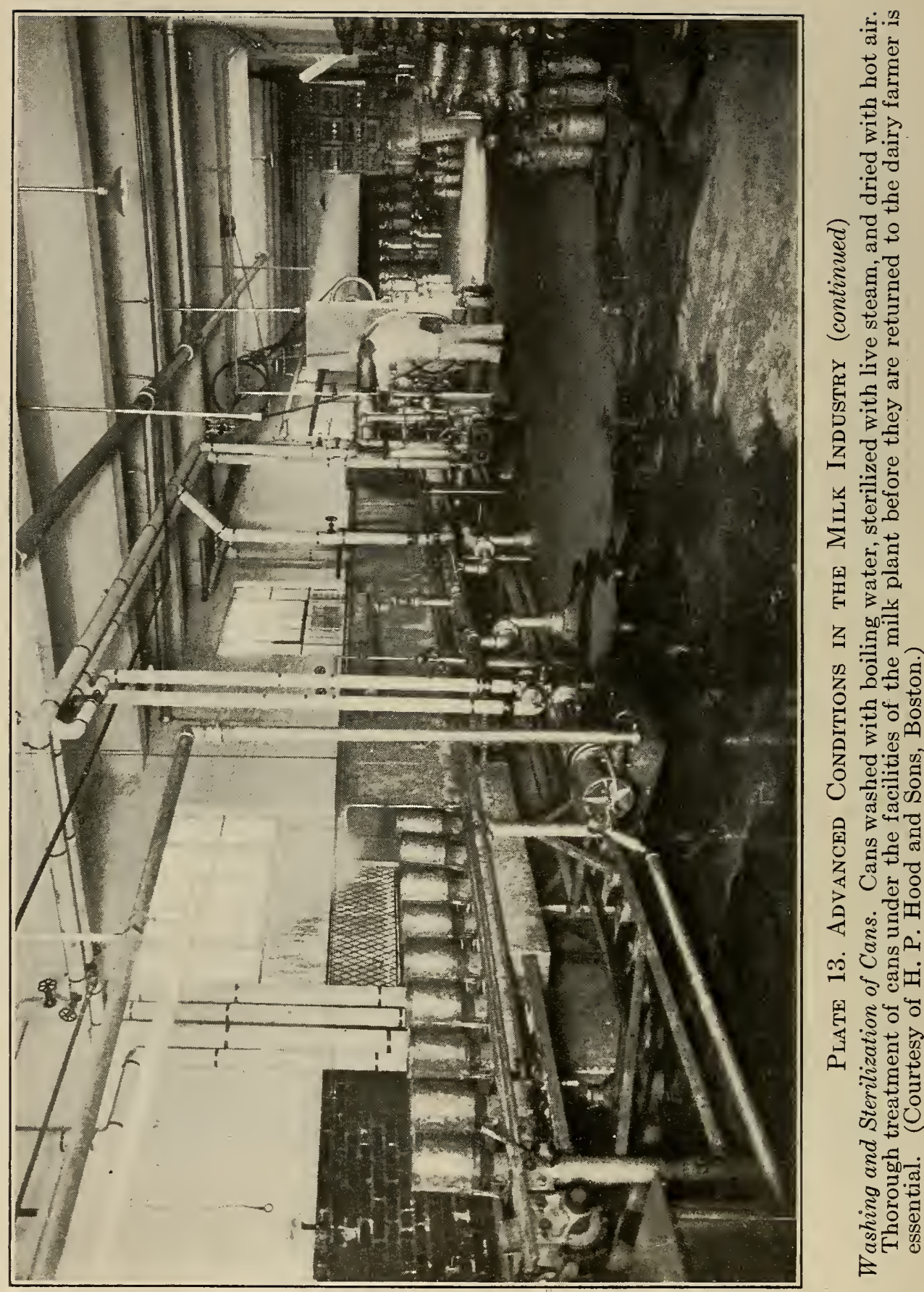

cities, where, fortunately, facilities in the shape of modern commercial milk plants are often found. In such centers it is rapidly gaining ground, and the bulk of the milk supply in certain cities is now pasteurized. Many large milk concerns have taken up the process as a means of self-protection against the possible consequences of unpasteurized milk.

In smaller cities and towns, on the other hand, the need of pasteurization has been largely unrecognized and has not made the progress that conditions demand. It should be noted that the principles of grading recommended by the National Commission on Milk Standards (Appendix B)-which allow for only one kind of unpasteurized milk, in the highest grade-are intended to apply to small as well as to large cities and towns. * Communities which do not choose or manage to adopt this standard suffer under greater or less disadvantage or danger. Some of the smaller communities have, indeed, adopted the clean raw milk ideal. Montclair, N. J., and Palo Alto, Cal.,- to name two widely separated towns-have under expert administration, carried that ideal to a high point. They have considered it their chief object to secure clean raw milk and to minimize its possible dangers. $\dagger$ But in both these cases it is to be observed that all market milk

* The latest report of the National Commission on Milk Standards states that "for the use of small dealers in cities and small producers for towns and villages, efficient pasteurizers costing less than $\$ 200$ are available. The Commission, therefore, thinks that milk ordinances for towns and villages, as well as for large cities, and also state milk laws, should provide compulsory pasteurization, except for Grade A raw milk."

$\dagger$ Pasteurized milk is, however, provided for under the regulations of these towns. 
sold raw must meet the requirements which the Commission classification prescribes for the highest grade. The centralization of pasteurization, bottling, and distribution at a few plants or a single plant in the smaller cities and towns would promote economy and simplify sanitary supervision. (See pages 171 and 250.)

The value of pasteurization in making possible the use of milk from cows which would otherwise be excluded by the tuberculin test is not sufficiently recognized. In the East pasteurization has gained a foothold which seems likely to be permanent. In other parts of the country, especially in the South and in the far West, agitation for the tuberculin-testing of dairy cows and opposition to the pasteurization of milk appear to be in full sway, and the conditions seem to be very similar to conditions in the East five and ten years ago. It is certain that in due time the South and West will come to realize the importance of pasteurization and will give it the same prominence which it has aiready gained in the East.

In brief, pasteurization is the most powerful single instrument that milk sanitation possesses to-day. Combined with adequate bacteriological control, it meets conditions which cannot be met by unsupplemented clean milk methods. Theorists may say that it should be unnecessary, but inexorable conditions leave no choice.

In summing up the matter of pasteurization we cannot do better than quote the remarks of Professor William T. Sedgwick, in his presidential address before the American Public Health Association, on American achievements and failures in public health work:- 
We have as yet, and in spite of ample knowledge, failed to make our American milk supplies what they should be. This is partly because we have been too timid to insist that good milk not only costs more to make but is worth more and must therefore be paid for, and partly because we have not yet taught the public as we should that the only safe milk is cooked milk, and for infants, milk that is pasteurizedpreferably in the final container. I have myself lived through the last year of the period-now happily remote-when no milk was pasteurized by anybody; through the next in which only pioneers like Nathan Straus preached or practiced pasteurization, while many, if not most, physicians deprecated the practice; through the one following, in which the scales began to turn in favor of pasteurization; and into the present when almost no one fully informed on the subject actively opposes pasteurization. And yet, even to-day, some physicians are shortsighted enough to tolerate if not to recommend the general use of raw milk, which still constitutes the great bulk of the milk used by infants and adults all over the land. Such use of raw milk we must count as long as it lasts one of our worst public health failures. ${ }^{30}$

\section{CLARIFICATION AND OTHER PROCESSES}

Ordinary farm milk contains more or less dirt, as well as natural waste from the udder of the cow, and often pus and bacteria from udder inflammations unnoticed or unnoticeable. By passing the milk through a centrifugal machine, or "clarifier," these matters are largely thrown out in a residuum which consists partly of substances normally present in milk and partly of those which are adventitious or abnormal. ${ }^{31}$ (Plate 5.) The quantity of this is stated by North to be ordinarily about one pound to every six thousand quarts. The process has come into wide use in milk plants as a trade 
measure, to remove the visible dirt which would interfere with the sale of bottled milk. It has thus been used to a greater or less extent to take out dirt that should have been kept out. At the same time the process has safety and decency values and is worthy of favor when used in connection with proper supervision of supplies and methods. Its exact status, however, has not yet been settled, and present evidence does not warrant the requirement of general clarification, as has been proposed in some quarters. (For a summary of advantages and disadvantages see $3 \mathrm{~d}$ Report of the National Commission on Milk Standards.)

The scope of this volume does not permit mention of the various processes of milk adjustment and manipulation which are practiced in the industry or discussion of how far these may be legitimate or the reverse. A mechanical process which has come into some prominence in recent years is that of homogenization of milk or cream. ${ }^{32}$ In this process the fat globules are forcibly broken up so as to be in more intimate mixture with the liquid. The process makes possible also the admixture of inferior fats. It is chiefly used in ice cream manufacture, but has other uses, among them being the production of an apparently greater richness in cream. There is no objection to homogenization in itself, but fraudulent practice is, of course, possible. The product should be fully labelled.

\section{PUBLICITY OF RATINGS}

The desire to more than maintain merely a minimum standard has led in many instances to the publication of the ratings of milk supplies. (The town of Mont- 
clair, N. J., was perhaps the earliest to adopt this method in order to secure the co-operation of its citizens in favoring the best milks.) Such ratings have been given out in reports, bulletins, and newspapers, in answer to inquiries, or posted publicly. Besides general observations, publication has been made, by name, of dairy scores, laboratory analyses, and verbal descriptions of the sources of supplies.

Such publication is advantageous with the more inquiring citizens, but such value is largely limited to small communities where that class is numerous. Even the intelligent reader, moreover, may find it difficult to interpret columns of figures for different kinds of data, while the characterization of milks as "excellent," "good," "poor," etc., is but a makeshift for accurately defined grades. Where, however, official grades have been established, supplies may, if desired, be further rated according to bacteria test, etc., within the grades.

The greatest effect of such publication is, after all, on the dealer. Even if only a few consumers read the list, the dealer is disturbed to find himself rated low and is stimulated to make some effort to improve his standing. But this effect is obtained in much more efficient degree under the grading system, to which we shall give next consideration.

\section{CONTESTS, CONFERENCES, EXHIBITIONS}

Contests in which dairymen compete for prizes for the best milk have been held by Federal and various State authorities, usually in connection with conferences, exhibitions, and fairs. Such contests and the lectures and demonstrations which accompany them 
have been an important educational force with dairymen and to a lesser degree with the public. It must be admitted, however, that they do not (nor are they intended) to go far toward the solution of the general milk problem; rather are they a useful auxiliary. Fair competition is to be encouraged, but can have full play only when degrees of merit are generally recognized in the market.

\section{THE GRADING OF MILKS}

We now come to the most recent and the logical development in the administrative control of milk supplies.

There was a time when just two general kinds of milk were recognized-good, or salable, and bad, or unsalable. As the situation grew more complex, and bacteriological analysis came into use, it was seen that the matter was not so simple. It then appeared to those who made a special study of milk supplies, that, while the supplies in large cities might be made to comply with certain minimum legal requirements, few-perhaps none with certainty-could be relied upon as fit for the use of infants and invalids. It was recognized as impossible to bring the general supply up to this desired standard. Hence the introduction of the milk depot for supplying special milk to the babies of the poor and the devising of a special grade of milk-namely, certified milk-medically supervised, for the babies of the well-to-do. Then, gradually, it came to be seen that these two special kinds-the one being on a philanthropic basis and the other costing a luxury price, could not solve the whole problem. Mean- 
while the situation had intensified; milk-borne disease became more and more insistent; a new factor had arisen in the shape of commercial pasteurization; the necessity of public control became more pressing. To-day the problem is how to exert such control in a way which is scientific, just to all parties concerned, equal to sanitary needs, yet economically practicable.

Progressive sanitary authorities have recognized the fallacy of attempting to make all market milks conform to the same standard by lumping ogether raw and pasteurized milks, milks for infant feeding and milks for ordinary household use. Distinctions must be made. The result has been the establishment of grades of milk publicly distinguished by means of simple labelling.

Such classification must logically be based on the uses to which milk is put and the corresponding sanitary criteria. The simplest division of uses is: (1) milk for infants, (2) milk for adults, (3) milk for cooking and manufacturing only. This requires three corresponding grades. The conspicuous criteria are bacteriological character and the application or non-application of pasteurization. It is essential that the grades be few, clearly defined, and readily understood.

The idea of milk classification is not new. A rudiment of it exists in the setting-aside of the special grade of certified milk, which, however, has never played a quantitively important part in general milk supplies. Dr. Ernest Lederle, then Health Commissioner of New York City, advocated as long ago as 1907 the grading of milks in some such manner as has since been effected in that city. Dr. A. D. Melvin, Chief of the Bureau of Animal Industry, United States Department of 
Agriculture, proposed at about the same time a classification (see below) which has done much to further the grading idea. Since then other systems have been devised. The principle is so rapidly gaining acceptance that the diversity of the different systems may become a problem in itself. As close conformity as possible to one generally accepted plan-e. g., that of the Commission on Milk Standards, cited below, would be desirable.

\section{Grading Systems}

The following, in outline, are some representative plans of classification. (For a fuller description of grading systems, see Appendix B.)

1. United States Department of Agriculture.

Class A. Certified milk or its equivalent.

B. Inspected milk (raw, tuberculin-tested).

C. Pasteurized milk.

(This classification is interesting as being, apparently, the first attempt to devise sanitary grades. It was proposed by Dr. A. D. Melvin, in 1908. It does not, however, express the ideas of to-day as do the following.)

2. National Commission on Milk Standards (of the New York Milk Committee).*

Grade A. Raw.

Pasteurized.

B. Pasteurized.

C. Pasteurized (for cooking or manufacturing purposes only).

* This classification applies also to cream. 
3. New York City.*

Grade A. Raw.

Pasteurized.

B. Pasteurized.

C. Pasteurized (for cooking or manufacturing purposes only).

4. New York State Sanitary Code.†

Grade A. Raw.

Pasteurized.

B. Raw.

Pasteurized.

C. Raw.

Pasteurized.

Some municipalities have partly recognized the grading idea through establishing standards for such milks as "Inspected" $\ddagger$ or "Pasteurized," and the principle is being increasingly adopted in milk legislation. There is nothing that would so quickly bring about the desired approximation to uniformity in methods of milk regulation as this principle. The grading idea has long been recognized in Continental

* This classification applies also to cream. It is closely similar to the preceding, there being some difference in the exact requirements.

$\dagger$ This classification applies also to cream if labelled or otherwise designated for purposes of sale. Certified milk is specifically authorized as an extra class and the term protected. It will be observed that this is a much less strict classification than the others, on account of its admitting raw milk to all three grades. It is, however, noteworthy as being the first state system of grading.

$\ddagger$ The term "inspected milk" has been used in various significations and is unsatisfactory. 
countries, though developed from a chemical rather than from a bacteriological point of view.*

With the grading system the education of the dairyman and of the consumer about which so much is said would come automatically. The one would learn exactly what is required of him; the other, exactly what he is getting.

An important concomitant of the system is the tonic effect on administration. Health authorities would find themselves freed of ineffective routine and would at the same time have to make their methods of administration so thorough as to bring out the full effect of the plan. It scarcely need be said that grading required but not fully enforced would be a conspicuous failure and only discredit an excellent principle.

* In Germany such classifications as: (1) Market milk, (2) Skim milk, (3) Infants' milk, are common. (Sommerfeld, "Handbuch der Milchkunde." Cf. Rolet, "Lait Hygiénique.") We have already referred to the Continental practice of domestic heating of milk, which partly takes the place of official safeguards, though pasteurization is now extensively practiced in Continental countries. In England, apparently, the grading idea has received little attention, and pasteurization of market milk has not made great headway. 


\section{CHAPTER IV}

\section{THE ECONOMIC FACTORS}

\section{Economic Value of Milk Production}

The economic value of milk as a food has already been made clear in preceding pages, and a glance at statistics presented elsewhere (Appendix A) will indicate the importance of milk production and distribution as an industry of the very first magnitude.

Quite aside from dairy specialization, milk production may be called an essential function of the ordinary farm. Dairying is an integral part of general farming. The dairy cow makes economical use of roughage and pasturage, and returns to the farmer milk for his own use as well as for sale. Furthermore the wastes of the cow stable have a large value as fertilizer. Dairying is often said to be the "backbone" of agriculture.

Again, the relative economy in milk production is much greater than in beef production. Good dairy cows produce human food in the form of milk far more economically than food products can be obtained in the form of beef, pork, or mutton. This is a fortunate fact for densely populated regions where intensive use must be made of agricultural resources.

\section{Decline of Dairying in Certain Regions}

But, in spite of this relative economy in milk production, there are regions where dairy farming is in turn 
found comparatively unprofitable. A table given in Appendix A shows a striking decline in numbers of milch cows in certain States the while populations are steadily on the increase. These States are those of New England and the Middle Atlantic seaboard where cities large and small abound. While, through better breeding, there may be some increase in the productivity of the milk stock, there is no doubt that the decline in milk production in these regions is very marked. The lower cost of milk production in more distant regions, makes it more economical for milk contractors to buy milk and pay the railroad charges from two or three hundred miles away, and many of the nearer farmers cannot meet the competition. This condition is hard on the latter and also adds greatly to the difficulties of milk sanitation, but it is a natural economic result of the growth of urban areas, their effect on the value of neighboring agricultural land, and their reaching-out, octopus-like, for ever-increasing milk supplies.

\section{THE CRUX OF THE ECONOMIC QUESTION}

While sanitarians and health officials have been agitating for the sanitary improvement of milk supplies, an insistent complaint has gone up on the part of the producer to this effect: that everything used in the production of milk has increased in cost during recent years, while the price of milk has failed to rise proportionately. Sometimes the assertion is even stronger, viz., that the price obtained by the farmer has remained stationary or has even decreased. It is from the dairy farmer that this complaint comes with ever-increasing 
force; to him the additional trouble and expense of complying with sanitary regulations are the latest aggravating factor in the situation.

Since the above statement seems to sum up the complaint of the producer, it must be examined in some detail, especially as it runs counter to the impression of many householders that the price of milk to the consumer has risen at a rapid rate and is partly responsible for the increased cost of living.

\section{THE PLIGHT OF THE FARMER}

In many regions the cry goes up from the dairy farmer that he is being "forced out of business." It is asserted that many farmers to-day are producing milk at a loss and that many more are going through the processes of dairy farming with little or no return for their investment and labor. "It is claimed," says an official of the United States Department of Agriculture, "that only about one-third of the dairy cows in New York State are kept at a profit. If this is true of New York, it is probably true of many other States." 1 Testifying at a Federal hearing on milk rates, at Boston in 1916, Professor Frederick Rasmussen of the New Hampshire State College of Agriculture, is reported as asserting from computations that the "average milk" in that State was produced at a slight loss. ${ }^{2}$ (This statement, though indefinite as reported, may apparently be taken to mean that more farmers producing milk in New Hampshire do so at a loss than at a profit.) Several years ago a farmer, "reported to be the most successful in New England, in a public address stated that the price received by him for milk during the 
past year gave him no profit whatever on his product, but brought him out just even. If this is true of the most successful farmer in New England, what is to be said of the great majority of the men engaged in milk production?" 3 Magazine articles have appeared under the titles, "The marketing of milk-how farmers are driven out of business and the cost of living is forced up" and "How New England dairy farmers are driven out of business." * While such statements are usually couched in general terms, they are, coming from many quarters, significant.

We have already, indeed, in Chapter II, referred to the plaint of the farmer, but it is so outstanding a feature of the milk situation to-day that a few further words here, before proceeding to its economic basis, will not be out of place. Some of the more specific complaints of the farmer are expressed in the following passage from the editorial column of a Southern newspaper:-

The dairyman is a manufacturer of milk. His cows are his machines - and very delicate ones. They are liable to disease and death. At the best they will not produce milk the year around, probably only two-thirds or three-quarters of it. He must have enough of them to allow some of them to occasionally "loaf on their job." If he has much of a herd he must keep a registered bull costing in the thousands, often. . . . [A high-bred cow] will cost as much as $\$ 300$ in her heiferhood, in many cases. . . .

These machines and their product alike require great care and attention to prevent them from becoming diseased themselves or being the means of diseasing the dairyman's

*Current Opinion, November and December, 1915. 
customers. They must be tested for tuberculosis, and, if they develop it, he must kill them or have them killed. The milkman's stables have been proved, in some cases of careless dairymen, to be foci of disease, especially typhoid and consumption. Therefore, he must submit to sanitary regulation and examinations that the public may be assured of pure milk, for disease germs increase rapidly in milk. Where the product is not pure it is one of the most dangerous of foods, as pure milk is one of the best possible.

Not only must his milk vessels be scrupulously clean, but there is considerable labor and expense involved in making absolutely clean the bottles in which he delivers the milk. He must be watchful . . that his help may not be possible "typhoid carriers," or otherwise liable to pass disease germs into the milk from their hands ... ; his cows must also be clean before they are milked. All this that his customers may have pure, clean, wholesome milk.

All of this means a greater expense than was ever dreamed of by the milkman of old, who drove up to your door and ladled out a pint or a quart of milk from a big can into the can or kettle you presented to him for your daily serving. Yet we have given here only an incomplete skeleton of the modern dairyman's extraordinary expenses.

His ordinary expenses are greater, because the cost of feed is so much higher than it was a score, or even a decade, of years ago. Nor will the health authorities allow him to keep his herd in such a cheap barn as that in which the 10-cents-aquart* milkman often kept his cows--dark, ill-ventilated, perhaps rarely cleaned.

$\mathrm{He}$ is not only entitled to some return on the capital invested in his milk-producing machines and his tools, but also to day wages as a workman. No matter how much help he may have, he must, if he would have his business thrive,

* Milk is more expensive in the South than elsewhere.-J. S. M. 
begin his day's work at 2 o'clock in the morning or some other such heart-rending hour, to gather his product and start it off to his customers-for there is no middleman in the dairy business. Rising in the small hours of the morning to begin work by lamplight, he sometimes knows no rest until some hours after darkness has come again.

Yet his profits on the nutritious article of food he sells bear no comparison with those of the grocer, butcher or baker.

To demand food that is entirely free from suspicion of carrying disease to ourselves and our children, and then to quarrel because we must pay more for it is utterly childish. ${ }^{4}$

The foregoing was prefaced with the statement that "pure milk, clean milk, cannot be sold at the price of dirty milk," and was entitled "We must pay the cost."

It is certainly worth examining how far the extra costs that are putting the farmer out of business are unavoidable and how far, therefore, "we," the consumers, must pay them.

\section{Is the Farmer Getting a Fair Price?}

This burning question, which lies at the very root of the economic problem, has been well discussed in a paper by Mr. Ernest Kelly of the Dairy Division, United States Department of Agriculture, who writes as follows (italics inserted):-

Within the last few years there has been much dissatisfaction among both milk producers and consumers. The dairy farmers claim that they are not receiving enough for their milk, while consumers complain that they are forced to pay exorbitant prices for the same article. It is apparent 
to anyone who has looked below the surface of this question, that many dairy farmers to-day are not receiving a price for their milk which will yield a fair profit. . . . In view of the increased cost of producing and handling milk and considering its high food value, consumers in many cities are paying a price which is much too low to allow a reasonable profit to the producer. The dairyman receives at his shipping station from about 2 cents to 5 cents per quart for his milk, depending upon the time of year and upon the city in which his product is marketed. Probably the bulk of market milk in this country is sold by the farmers at about $31 / 2$ cents per quart, whereas the price to the consumer in the various cities ranges from about 6 cents to 10 cents per quart, depending upon the locality and upon whether the milk is sold "loose" or bottled.

It is extremely doubtful if the dairyman in many cases received enough for his milk to pay for the bare cost of production at these prices. Bulletin 73, issued by the experiment station at Storrs, Conn., gives the cost of producing milk on the experimental farm for a period of five years. When the milk produced by the herd was figured as worth 4 cents a quart at the farm, the business was conducted at a loss every year out of the five. Where the milk was figured at 5 cents a quart at the farm, the books showed a net profit four years out of the five. Results similar to these have been obtained at several other stations. ${ }^{5}$

Mr. Kelly presents in his paper some exceedingly interesting figures which the present writer has elaborated and brought up to date and plotted in Figs. 15-20. A glance at these charts will show that the rise in the retail price of milk as compared with some other staple food products has been relatively slow. The figures upon which these curves are based were compiled by the 
Government from the most important industrial cities throughout the United States. ${ }^{6}$ The level of 100 shown in each chart is the base of the relative prices, - that is, the price indices relate to a value of 100 representing the average price for each food during the period 1890-99, so that they give percentage variations and may be directly compared. In the last of the series

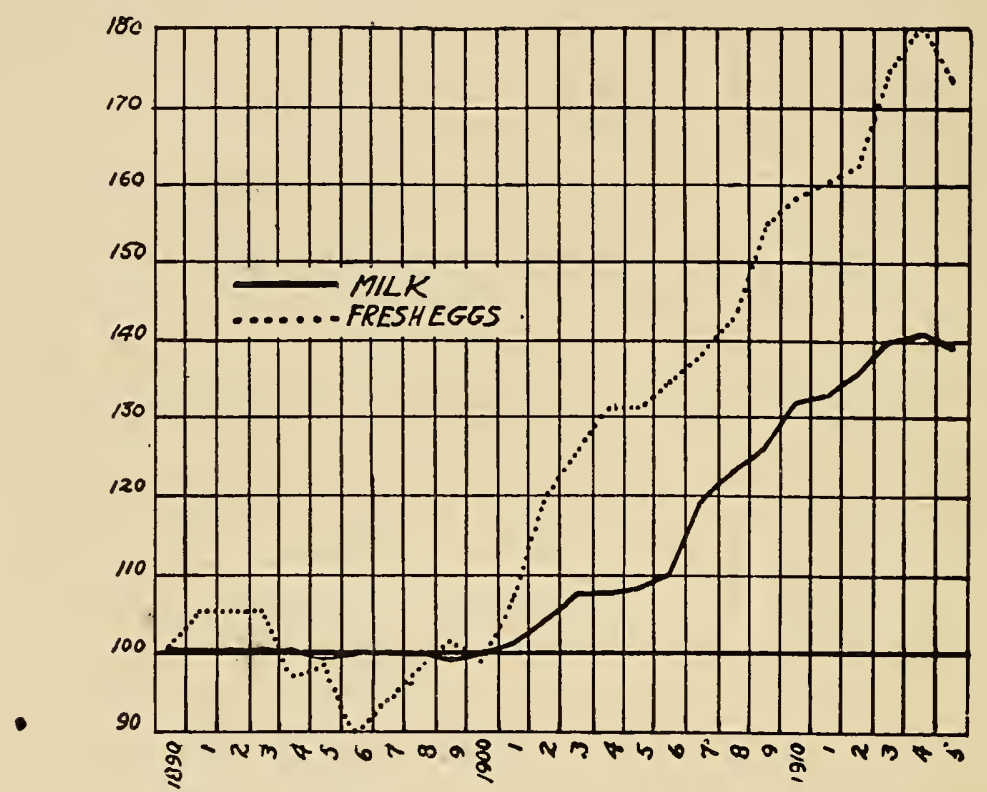

Fig. 15. Relative Retail Prices, 1890-1915:

Milk and Fresh Eggs

a combined curve is given for the five staple foods as compared with milk. It will be seen that, with the exception of wheat flour, these have increased in price more rapidly than milk, and, taken all together, markedly.

The economy of milk as a food has already been referred to in Chapter I, but may here be re-emphasized. It was there pointed out that milk is ordinarily one 
of the cheapest of foods,- - a fact reinforced by the considerations that it is free from waste material, is easily digested, is indispensable for infants and children, and may be used either without preparation or in ready combination with other food materials.

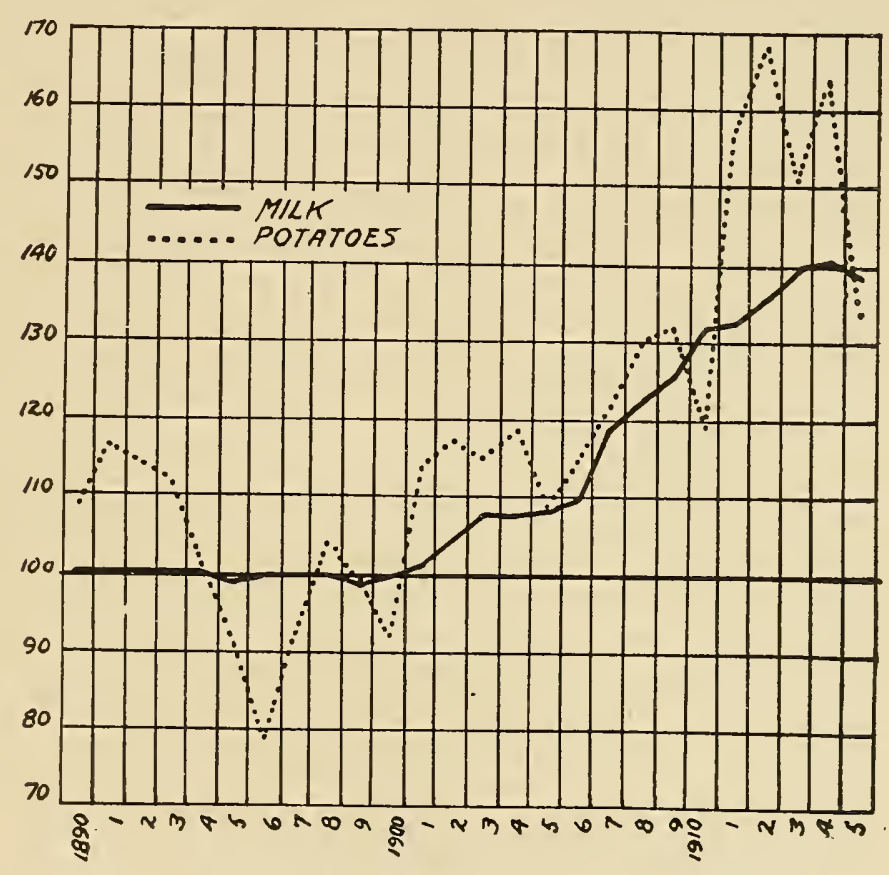

Fig. 16. Relative Retail Prices, 1890-1915 Milk and Potatoes

We may now examine the complaint of the farmer that the cost of producing milk has increased greatly in recent years without a commensurate increase in the price of the product. Data on this point are set forth in Fig. 21. This shows the relative increases in the two great items of cost of farm labor and of cattle feeds,items which constitute 80 to 85 per cent of the total farm cost of milk production. Labor for the dairy 
farm is hard to secure at any price, for many farm hands object to milking and will not hire out where they have to do this kind of work. In the chart the value 100, as

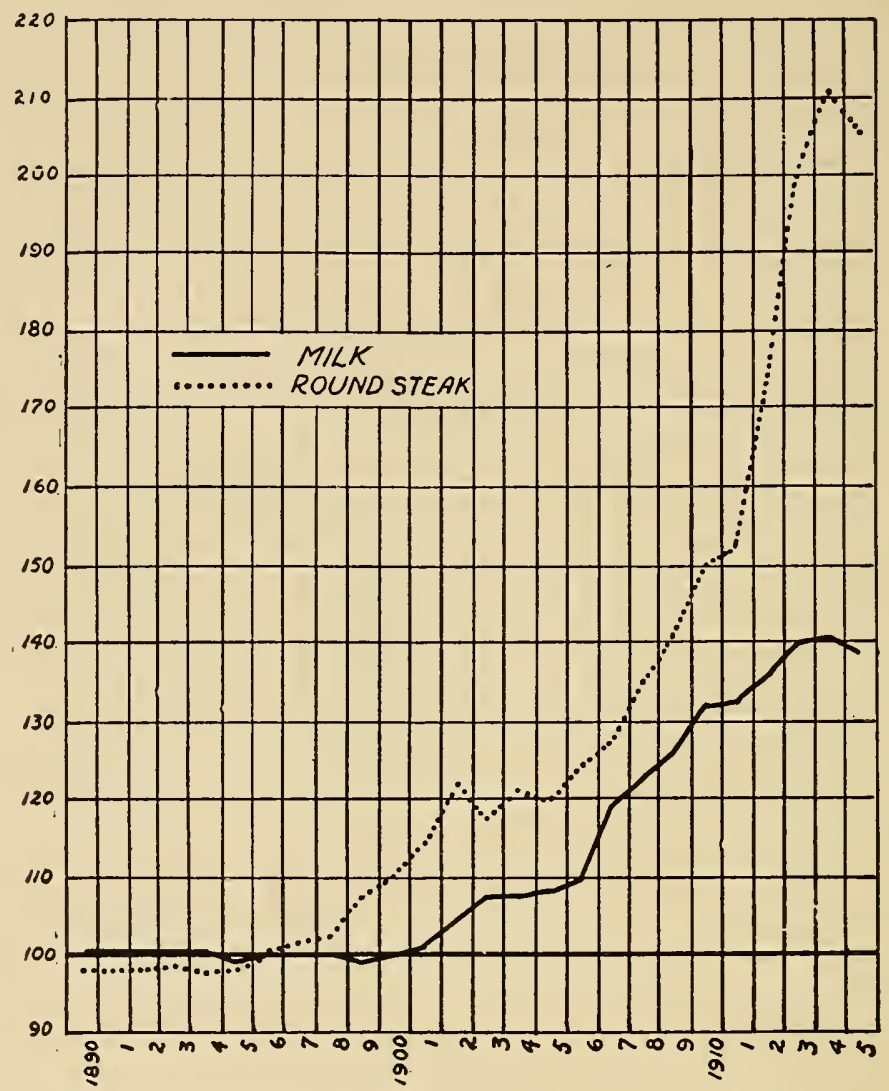

Fig. 17. Relative Retail Prices, 1890-1915 Milk and Round Steak

before, represents the ten-year average of prices from 1890 to 1899, inclusive. This chart is taken from a paper by Mr. Kelly on factors influencing the cost of milk to the consumer. ${ }^{7} \mathrm{Mr}$. Kelly describes the manner of constructing the dotted curve and draws conclusion from it as follows (italics inserted):- 
From the source already noted,* figures were compiled showing the increased cost of all the various staple grains which are used for cattle feeding, and also the increased cost of hay. These two sets of figures were combined, giving

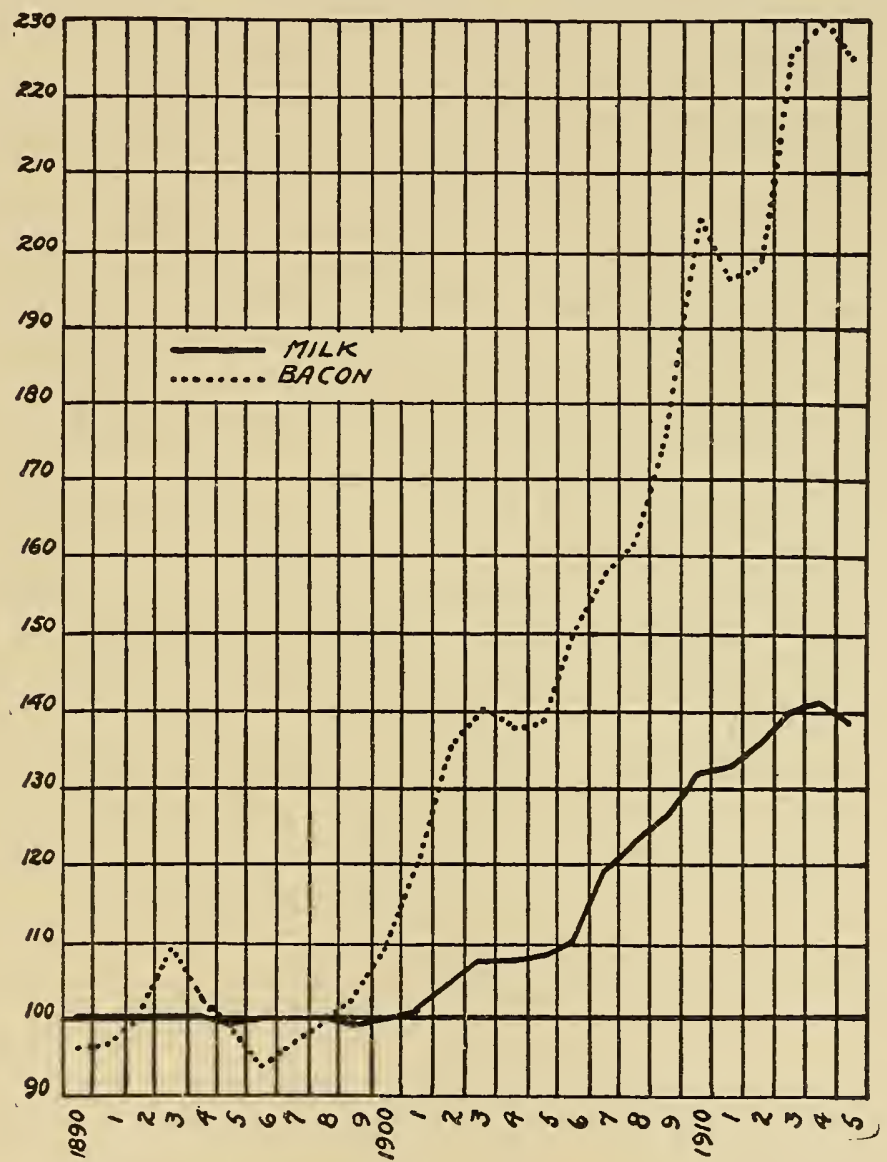

Fig. 18. Relative Retail Prices, 1890-1915

Milk and Bacon

the two varieties of feeding stuffs (grain and hay), the importance which they would play in the feeding of an average dairy cow. From this combination of figures was plotted a curve called the "feed curve." A separate curve was plotted

* Bulls. 94, 99, U. S. Dept. of Commerce and Labor. 
for the increased cost of farm labor. Finally, these two curves, viz.: the feed curve and the labor curve, were combined into one, giving each of the two items the weight which would be attached to it in the maintenance of the average cow. The combination of the feed curve and the labor curve is represented by the dotted line. While this curve does not represent the total cost of milk production, it does represent about $83 \%$ of the total cost, and the other factors which go

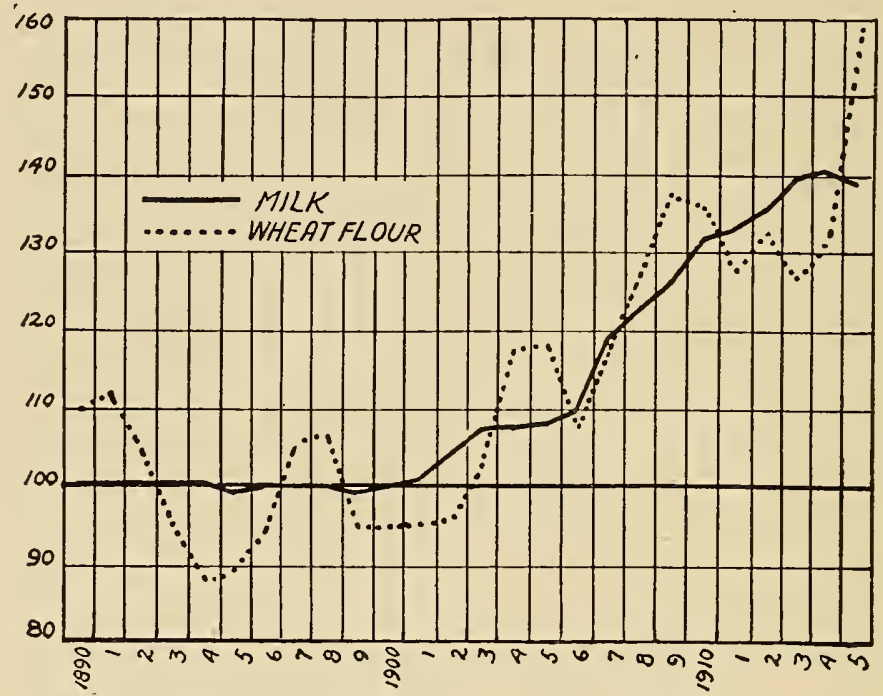

Fig. 19. Relative Retail Prices, 1890-1915 Milk and Wheat Flour

to make up the other $17 \%$ have probably increased in at least as rapid a ratio.

After studying this curve there can be no doubt that the average milk consumer is paying much less for milk than is warranted by the increased cost of production, to say nothing of the increased cost due to the more elaborate system. of distribution now in force.

Finally, Mr. Kelly draws the following general conclusion :- 
The consumer is already buying his milk at a low price as compared with many other foods, and if he wishes a clean milk he must expect to pay more in the future than he does at present,

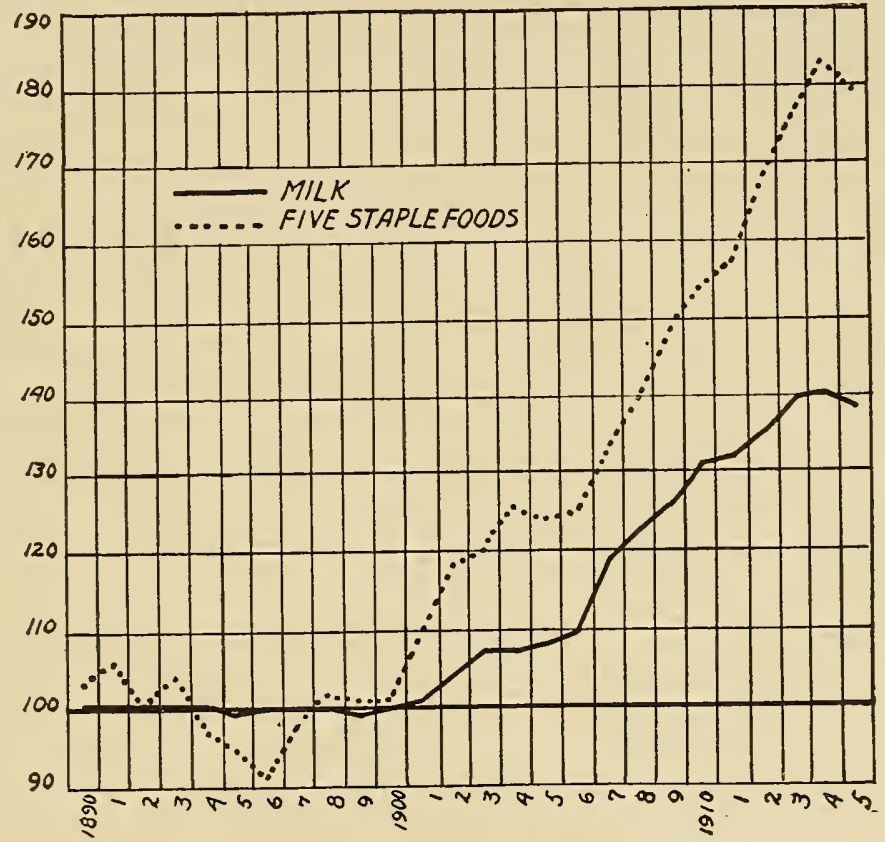

Fig. 20. Relative Retail Prices, 1890-1915

Milk and Five Staple Foods

unless a more economical method of production and distribution can be installed.

\section{Another Aspect}

Such considerations strongly support the case of the farmer. Still, they require some qualification. The matter has another side which we have not yet considered. It is well put by Mr. Kelly (italics inserted):-

The dairy farmer himself is not blameless. Sometimes his business is carried on in a wasteful, extravagant manner. Unprofitable cows are kept, and uneconomical methods of 
feeding are followed. It is unfair to ask the milk-consuming public to pay him a profit on such a slipshod system, and yet that is what is often expected. ${ }^{8}$

This widespread condition of agricultural and business inefficiency is fostered by the fact that a great

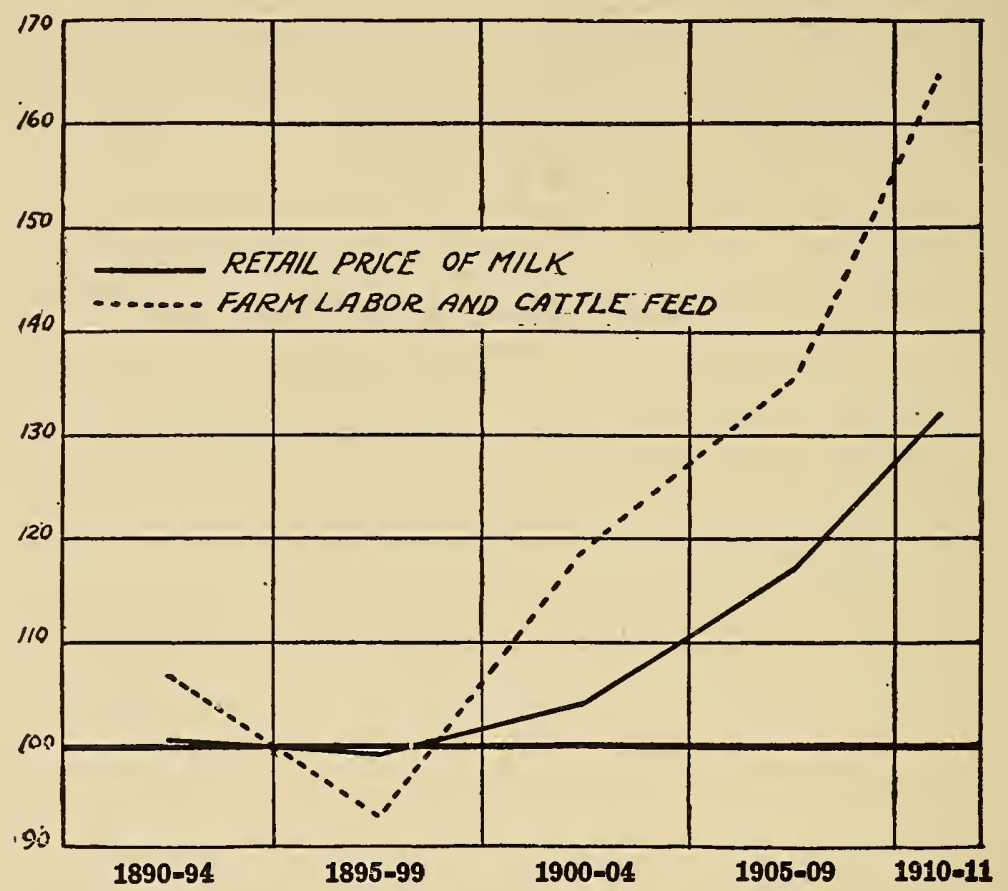

Fig. 21. Retail Price of Milk Compared with Costs of Production

Five-year periods, 1890-1911.

deal-perhaps the bulk-of market milk comes from small farms where it is regarded simply as a by-product. The farmer keeps a few cows for his personal use and sells the excess product. He gives the subject of milk production just as little attention as he can. The state of affairs is described in further detail by another Government agricultural expert:- 


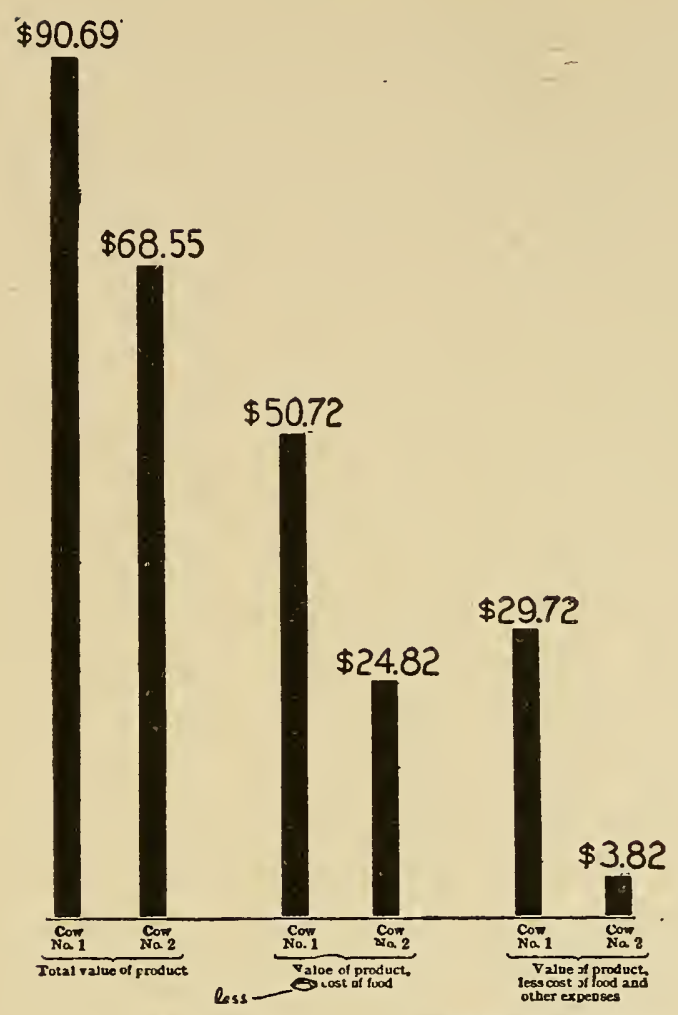

Fig. 22. Profit from Different Cows

Average annual value of product from two cows for three years. Observe the scant net profit on Cow No. 2, compared with No. 1, as shown by the two bars at the right. The values of his cows as producers are of the utmost importance to the dairy farmer, yet few farmers have any exact knowledge as to which cows in the herd are bringing in a profit in relation to the cost of their keep and which ones are kept at a loss as "boarders" or "rabbits." Yet such knowledge can be gained simply by keeping records for individual cows and, when possible, making butter-fat tests. Such differences as the above are very common in dairy herds, and greater ones are often met with,- facts which must be considered in connection with the complaint from the farmer that "there is no money in the milk business." (Circulars 67, 122, Ohio Agricultural Experiment Station.)

As I visit the dairymen of this country, I am impressed with the statements that they make in regard to the amount of milk received per cow. Some dairymen say their cows are 
averaging about one gallon each, while others say theirs give three. Why this difference? There are several things that might assist in this condition of affairs, yet I believe it is principally accounted for by the difference in cows. A profitable cow costs little more to keep than an unprofitable one; yet farmer after farmer is keeping these scrub cows. It is also a question of the dairyman not really knowing which are his profitable cows and which the "boarders." Too many think they have no time for the Babcock test and the scales. If dairymen are to produce milk on an economical basis, they must start with better cows. Then they must properly care for and feed these cows if best results are to be obtained. Successful dairymen are using silos, growing alfalfa, etc.; therefore other farmers should study these matters.

Again, as one travels over this country, he cannot help being impressed with the many kinds of waste that are continually occurring on our farms. The farm machinery that should last a number of years is allowed to deteriorate rapidly because it is not properly housed and cared for. One of the most valuable assets to the farm, namely, the liquid manure, is allowed to waste by soaking into the ground near the barn. Even the solid manure is thrown under the eaves, and the soluble elements, which are the best form of plant food, are allowed to be lost. So we might mention loss after loss that is continually occurring on our farms, mainly because of poor management. I can hardly see how the dairyman can expect the consumer to pay for such losses; yet that is really what he wants when he allows these conditions to exist, and cries for better prices. ${ }^{9}$

From this it is clear that, while justice must be done to the farmer in a fair price for his product, he must, if he is to stay in business, use business methods. Not that he can be expected to become an agricultural or. 
business expert, but he should certainly take advantage of the expert information and advice now available to him. One great drawback is most farmers' apparent inability to make use of printed matter. Federal, state, and college authorities are continually publishing literature that should be in the hands of milk producers, yet it is surprising how few avail themselves of this free information as well as that contained in dairy periodicals. There are indeed hopeful signs in the increasing attention being paid to high-grade stock, to cow-testing for the purpose of weeding out animals which are kept at a loss, and to other points of management. But it is evident that a great deal of agricultural extension work - to take knowledge personally to the farmer-will be needed to bring about the requisite improvement in dairy husbandry.

There has naturally come about considerable specialization of dairy farms. The larger these are and the more closely organized and managed, the greater will be the profit. This development has suggested that the small dairy farmer may eventually be crowded out of business. How far this may come to pass is hard to tell, but the economic function of the dairy cow on the ordinary farm indicates that we must still continue to depend upon the ordinary farmer for a large share of the milk supply. So far as sanitation goes, by the simple methods outlined in Chapter III sanitary milk can be produced, at a moderate cost, on almost any kind of farm by ordinary dairymen.

A certain number of all businesses fail, and one cannot hope that every last dairyman can be made successful. But standards can certainly be raised. And 
it is to be hoped that not only will justice be done to the farmer, but also that he will make use of the means of his own advancement, thereby benefiting simultaneously the consuming public and himself.

\section{FACTORS IN THE FINAL COST OF MILK}

The various factors which make up the total cost of a unit of milk may logically be considered under the following heads: (1) Production, (2) Transportation, (3) Handling in country or city milk plant, and (4) Delivery to the consumer. A detailed consideration of these would split them up into a number of items to be figured separately. Thus, for production, which includes all that is chargeable to the farmer, the subheads would be: interest on investment; insurance, taxes, etc.; cost of feed; labor cost; miscellaneous charges; and hauling to the station or milk plant when the farmer does not retail his own product.*

A number of special studies dealing with the costs of the various processes and stages have been made, some of the findings of which are gathered together in Appendix D. In considering cost figures it must be remembered that very few dairy farmers keep even approximately accurate records, so that at the present time it is impossible to get data of this kind except by means of special investigation; and also that, on account of trade reticence, it is difficult to obtain in-

* Further details on figuring milk costs are given in the paper by Kelly already referred to and in the various special studies cited in Appendix D. 
dicative figures from dealers, although the large companies of course figure carefully their own particular items. Data on production costs have been gathered by various experiment stations, and show considerable differences according to locality.

Systems and rates of transportation as complicating factors have elsewhere been referred to (Chapter II).

The cost of distribution has come in for special attention. A large proportion of the total cost of milk is chargeable to this item. The Boston Chamber of Commerce investigation showed that "the greatest single item of cost is delivery to the family trade, equaling the total cost of collection in the country, the operation of country plant, railroad transportation, and city plant expenses." In some cases it approaches the price paid to the producer. A notable study of the distribution situation in one city, Rochester, N. Y., has been made by Dr. John R. Williams, ${ }^{10}$ who estimated the difference in cost between an assumed model system of distribution and the system actually existing among the distributers.* This difference was surprisingly large, the extra cost due to the duplication of routes and dispersion of customers under trade conditions figuring to some $\$ 500,000$ yearly for that city. Bottle losses were also a very considerable item, estimated at about $\$ 10,000$ a year. Such charges are, of course, paid by the consumer in the retail price. Dr. Williams presents statistical details from investigation

* The U. S. Department of Agriculture has collected figures showing large variation in the economy of distribution as practiced by different dealers. (Milk Plant Letter 15.) 
and experiment, and concludes with a plea for central delivery under municipal management of milk supplies.

Various practical objections have been brought against the idea of a central delivery, either privately or municipally managed. A number of such objections were collected by the Boston Chamber of Commerce committee. ${ }^{11}$ The idea has apparently not been tried in practice. As a trade measure such centralization would necessitate the actual formation of companies large enough to undertake all the operations connected with large volumes of milk, for delivery is so vital and competitive a part of local milk trade that it is difficult to see how mere co-operation could be made to harmonize with individual interests. Otherwise the individual dealer would be left so limited scope for initiative and activity in competition that general discontent would be inevitable, and either complete amalgamation or the restoration of previous conditions would be a forced conclusion. Co-operative plans and municipalization will be further discussed in Chapter V. A general criticism of such proposals is that they minimize or omit practical difficulties and dangers in organization and operation.

The tendency of the trade in the cities to become concentrated in the hands of comparatively few dealers or companies is a hopeful factor in the delivery situation. It is clear that such concentration favors greater efficiency and economy in handling in all respects. It may be added that the sale of milk from properly supervised stores is another means of lowering the cost of distribution. 


\section{THE MILK DEALER}

In what may be called the semi-developed state of milk industry the farmer produces and distributes his own product, perhaps deriving a greater or less part of his supply from his neighbors. In the developed state the milk dealer is differentiated as a distinct individual. The dealer collects the milk brought in by producers, either at a country bottling plant or, more frequently, at a city plant to which the separate supplies have been brought, usually by railroad. The dealer thus specialized is not only able to carry on milk processes on a large scale, but also can dispose of surplus milk through the channels of the manufacture of butter, cheese, etc. (Establishments for these last uses are called "creameries," a term sometimes loosely applied to milk depots or milk plants proper.) Urban conditions not only make it difficult or impossible for the farmer to distribute his product himself, but further tend to force the small dealer either to go out of business or to amalgamate with others in the formation of businesses of economic size,--hence the large dealer of to-day.

The dealer thus occupies a central point from which he can see, and to a certain degree control, all the ramifications of the industry. But, while he possesses an advantage in being more of a business man than is the farmer, and may use this advantage unscrupulously, his position is not always an easy one. Often, as Dr. Charles E. North wrote several years ago, "he finds himself opposed on the one hand to the public health authorities in the city where he markets his 
product and, on the other hand, he is opposed by the milk producers from whom he secures his raw material. In some districts these antagonisms have become so acute that the large dealer has a tendency to believe he must look upon the dairy farmers who produce milk and the health authorities who supervise the industry as permanent enemies of the milk business." Obviously, the remedy for this is mutual understanding, fair dealing, and the adjustment of aggravating conditions.

\section{Dealer and Farmer}

The general situation between dealer and farmer has already been considered in Chapter II and need not be further discussed here. Projects to eliminate the middleman, wholly or partly, as a supposed special obstacle to the solution of the milk problem, have been offered, the merits of which will be discussed in Chapter V. We may consider for the present the concrete, practical plan of farmers' co-operative milk depots in country districts. One of the principal recommendations of the Boston Chamber of Commerce committee of investigation into conditions in New England* dealt with this idea as follows:-

A plant, [reported the committee] well built and equipped would cost from $\$ 2,000$ to $\$ 20,000$, according to its capacity and the number of operations carried on. The plant could be owned by the farmers and business men of the locality. Money could be raised by the issuing of non-voting preferred shares to the business men and investors locally, and voting common share to the farmers.

* See Appendix E. 
The producers would then have facilities for the disposal of their product in the manufacturing of butter or cheese, if they are unable to secure satisfactory prices from the dealers.

Producers may look forward to receiving more from their product when they cease to allow others to furnish them their cans, to collect (taking all grades, little or much), to dictate price and to process, grade and market their milk and cream.

Co-operative creameries have failed in the past largely because of inefficient management (a poor bookkeeping system, no allowance for depreciation, no allowance for surplus, no safeguard preventing one or two persons from gaining control of the company, and the lack of knowledge of new methods of testing, manufacturing and marketing).

A milk plant is important to the prosperity of the community. A certain small plant, not well equipped or managed, in one of our New England localities, paid the farmers last year nearly $\$ 100,000$, which brought as much money into the community as many manufacturing establishments employing one hundred and fifty to two hundred men each.

If, as this committee reported, "at present the general farmer has very little voice in determining the price to be paid for his milk and cream," and "takes what the dealer offers, which is generally the price for no special grade of product and is influenced largely by the yearly surplus," and is otherwise at a disadvantage,- - then this proposal of co-operative plants is one seriously to be considered. (For further details see the report of the committee. ${ }^{12}$ ) 
The care of surplus milk in the country was considered by the committee just quoted to be a very important matter:-

In addition to producing good, clean milk and cream and grading it, the producers, to assure themselves of greater returns for their product, would do well to process it and to make arrangements to care for the surplus. Too much emphasis cannot be laid upon the taking care, in the country, of the surplus; manufacturing it into butter, skim milk or cheese. As pointed out previously, this surplus item is one of the most serious causes for the present chaotic condition in the industry.

The above plan, it will be seen, proposes for the country a concentration at the farmer's end and for his advantage similar to that which now exists at the dealer's end in cities.

Many large dealers buy milk on a sliding scale which varies the price both according to month and according to percentage of butter fat. For years past farmers have been breeding cattle for quantity, not quality. The result has been a great increase in numbers of cows, such as Holsteins, which yield milk in large quantity but with a low butter-fat test. In the case of New York State the Legislature was induced to take account of this situation and lowered the legal minimum of total solids. In order to secure a sufficient percentage of cream the sliding scale of prices according to fat was adopted by dealers. This is obviously a fair way of buying milk, for it makes the distinction between, say, Jersey and Holstein cows and between high-test and low-test Holsteins.

Certain large dealers have also established premiums 



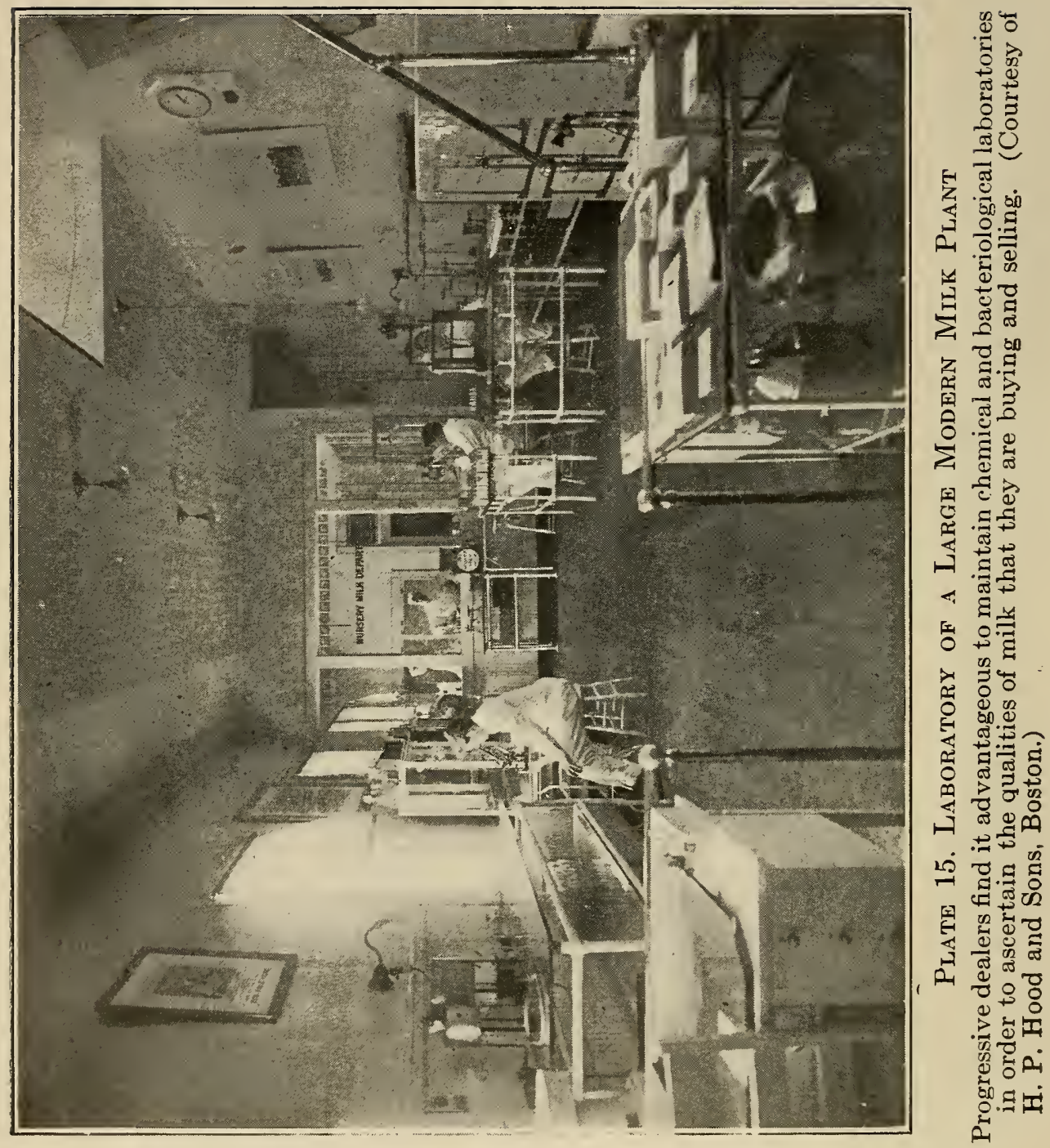


for milk of better sanitary quality. A rioteworthy example of this idea is the payment for low bacteria counts which is made under the North plan of milk production (page 78).

Such differential payments for milk are all in the right direction as recognizing the commercial value of quality and should be complemented by differential prices for the retail product.

For the purpose of avoiding uncertainty dealers enter very generally into contract relations with dairy farmers according to which certain quantities of milk are delivered at schedule prices over greater or less periods of time. These contracts usually fix the monthly prices for six months at a time. One of the large New York companies has recently adopted experimentally the new departure of monthly bidding.

The cry of "monopoly" is not infrequently raised by the farmer, and it is true that as an individual he often has no choice to whom and at what price he is to sell his milk. The farmer's remedy, as we have pointed out in a previous chapter, is organization to protect and advance his interests. Certainly, as an individualist he is at a vast disadvantage. There are some signs that the farmers are beginning to recognize this fact. Collective action, though spasmodic, has been effected in some instances, and the farmers' "milk strike" has recently come into existence in earnest.

\section{ANOMALIES OF MILK AS A COMMODITY}

Milk as a commodity is characterized by two peculiar facts which are to be considered in connection with the solution of the milk problem:- 
1. Stability of Retail Price.-While the cost of production of milk and the available supply vary from month to month, the price to the consumer remains constant through long periods. The explanation of this seems to lie in the regularity of consumption, which enables the dealer to depend on an average price to cover fluctuations in cost, and in the avoiding of difficulties which would arise from variations in the price of a commodity delivered on standing order. At the same time custom has brought about what one dealer has called "the tyranny of the conventional price," and any increase in the established price is sure to call forth a storm of public protest. Considerable increases in the prices of meats and other foods are accepted quite readily, for these prices are subject to constant fluctuation, but an increase in the price of milk is regarded as an encroachment. Proposed raising of that price often results in starting a "scare" with calls for prosecutor's investigation, - an interesting example of the power of convention. This is a condition naturally deprecated by the distributer of milk, through whom it reacts on the farmer.

Attention may here be called to the ticket system of payments as a means of adjustment. Under this system the dealer sells the customer for cash a strip or book of tickets each of which is good for a quart or a pint of milk. Because of the saving to the dealer in collections and the ease with which the amount charged for tickets can be adjusted so as to take account of fractions of a cent in the quart price, customers who use tickets can obtain milk at a lower rate than those who pay on credit in round cents. With or without 
this system, the adjustment of retail prices in fractions of a cent for regular customers seems worthy of more attention than it has received thus far. One of the large companies of New York has recently been considering the plan of a weekly retail price which will allow for fluctuations in cost.

2. Non-recognition of Quality Differences.-To the public "milk is milk," and naturally, for the consumer ordinarily has no knowledge of its source or actual sanitary quality. Its whiteness and cream line are all that are visible to the housewife. Hence, while eggs, for example, are sold under four or five different grades, there is, so far as official designation goes, (certified milk aside), generally only one kind of milk on the market. Vital distinctions are thus ignored which it should be the object of regulation to make clear.

\section{ECONOMIC EFFECTS OF SANITARY REGULATION *}

Those who view the milk problem from the sanitary side are so apt to slight the economic bearings of sanitary regulation that some consideration of them here will not be out of place.

In the absence of any effective regulation market milk is bought and sold irrespective of sanitary quality. In this case "milk is milk" and there is one retail price for all except in so far as certain milkmen may have built up a public reputation of their own.

Where certain minimum sanitary regulations are put into effect, the situation, assuming that the cost of

${ }^{*}$ Cf. figures on cost of sanitary items, Appendix D. 
this minimum sanitation is no considerable item, will be much the same. Any tendency to increased price will be modified by the fact that cleanliness, refrigeration, and pasteurization do not operate entirely to raise costs, for they have an economic value of their own in preserving milk and making it more salable and would be practiced to some degree even if not required by public authority. Under this condition of enforced minimum standards some of the producers and distributers would doubtless naturally practice sanitation above the requirements, but those dealers who rise above the average in this respect would derive no extra recompense.

If, now, the sanitary requirements be made decidedly strict, a certain number of dealers will find themselves unable to meet them, and will go out of business. If the cost of production for the others is materially increased, there will then normally be a corresponding increase in price, and an increase will be further favored if the elimination of the other dealers has reduced the total supply. The increase in price may, on the other hand, reduce the demand, people preferring to use less milk and dealers handling no more milk than they can profitably sell at the increased cost of production. Under these conditions the milk industry tends to become concentrated in the hands of a comparatively few men who can give it the demanded special attention. This is what has happened, for example, in a town which is notable for its strict regulation, viz., Montclair, N. J., where the number of dealers has been much reduced and milk is sold at a higher price than in neighboring communities. 
Under the system of regulation by minimum, which has thus far been considered, it is clear that the price of milk normally takes a single level which corresponds, roughly, to the average cost of production. The poorest qualities of milk cannot be sold; on the other hand, qualities better than the average (with the exception of certified milk, where sold) bring no added price and there is no economic incentive to produce them.*

In a recent discussion of the milk situation in Vermont the Commissioner of Agriculture of that State, Hon. E. S. Brigham, ${ }^{13}$ mentioned three ways in which the situation might be improved:-

1. The limitation of the requirements of health boards to those things which are necessary to safeguard the public health.

2. The payment for milk on a basis which will make a distinction in price between good milk and poor milk.

3 . The securing for the producer of a price which will enable him to make a reasonable profit in his business.

Continuing his discussion of the economic question, the Commissioner made the plain statement, based on some analysis of figures, "I have yet to be shown where the shipping of milk, under present conditions, is of any value to our Vermont dairyman." Referring to the fact that the milk contractor will pay no more than he has to, the speaker advocated concerted action by the farmers in order to command higher prices. In regard to the second of the propositions quoted, the Commissioner asserted that, in accordance with the

* This condition may, of course, be modified by official publicity regarding qualities of milks. Such publicity is not, however, very effective except under special conditions. Cf. p. 115. 
economic principle stated in Gresham's law of currency, "if poor milk as a commodity of commerce commands the same price as good milk and is cheaper to produce, we may expect the milk supply to tend to approximate the poore $t$ quality which health officials will allow to be sold." Affirming that such premiums for quality as have been established by some contractors are "entirely inadequate," he continued:-

Now the question is this, Can milk which is dirty and loaded with bacteria be cleaned by running through a clarifier, have its bacteria killed by pasteurization, and still be a good, clean, wholesome product, fit for human consumption? If so, there is very little need to encourage cleanliness in production, because when the producer of clean milk sees his product emptied into the same vat with the product of the filthy producer, as is now the case, and he receives no reward for his pains taken, he soon grows tired of attempting to produce a clean product, and the quality of the milk supply sinks to a low level. I have been repeatedly asked by ... contractors to devise some way to encourage the production of clean milk. I have always inquired if clean milk was worth any more than dirty milk so that they would care to make an adequate distinction in price, but I have not yet had a satisfactory answer.

The remedy of this situation is obviously not the throwing of discredit upon clarification and pasteurization-processes good in themselves-but the establishment and enforcement by health authorities of standards which will act back to the original product and necessitate a monetary distinction between good milk and better milk and rule out the worse. For if certain official grades of milk are established (as was 
described in the last chapter), there is brought about a market condition in accordance with facts, each grade publicly recognized commanding a price corresponding to its quality and cost of production. This condition supersedes-or should supersede-any unofficial or ill-defined characterizations, such as are sometimes given to milk by dealers. Most important of all, from the economic standpoint, superior grades of milk are then no longer lumped with the inferior, but bring the higher price to which they are entitled. Only thus can justice be done to both producer and consumer. 


\section{CHAPTER V}

\section{HOW SOLVE THE PROBLEM?}

It now remains only to sum up the indications of the preceding chapters, together with some considerations of a more sweeping character.

\section{THE GREAT NEED: MANIFESTATION OF VALUES}

The great difficulty in the milk situation to-day is that values, both sanitary and economic, are not clearly recognized. Milk is the one staple food which varies in sanitary value, in food value, and in cost of production without these variations being generally recognized in retail price. This is the "milk is milk" difficulty.

Eggs are sold according to freshness, butter according to flavor, flour according to its bread-making qualities, meat according to the cut; but milk is sold, by an outgrown custom, as plain milk - a white fluid in a can or a bottle. If it can be sold as such, the dealer is satisfied; if he obtains cream for his coffee and an opalescent liquid for his children, the customer is content. The dairyman of slovenly methods may compete with the cleanly, careful dairyman so long as he manages to meet the minimum requirements of the law. He may get the same price, and his methods play the predominant part in fixing the market price of the product known without discrimination as "milk." 
For such reasons authorities are agreed that milk should be graded according to definite standards and should be labelled and sold on that basis. It only remains to put the principle into operation.

\section{Principles of Grading*}

The following considerations should govern grading:

1. It should take account of sanitary quality, i. e., of safety and decency.

2. It should take account of composition, i. e., roughly speaking, of nutritional quality.

3. It should be simple and practicable. The grades should be few and the requirements as simple as possible.

4. It should take account of uses, with special reference to infant feeding. $\dagger$

5. It should be evident to the consumer, which means clear and simple labelling.

The requirement of safety will make pasteurization essential for all grades except, possibly, raw milk of the highest class. The impossibility of immediately securing general pasteurization in many communities, especially small ones, may, however, necessitate concessions. This is the case with the classification prescribed by the Sanitary Code of New York State (Appendix B).

In addition to the criterion of pasteurization, the most feasible basis of classification as to sanitary quality

* For grading systems see Appendix B.

$\dagger$ A rational classification is: (1) For infants and children (Grade A, raw and pasteurized); (2) For adults (Grade B, pasteurized); (3) For cooking and manufacturing purposes only (Grade C, pasteurized or boiled-to be authorized only where necessary). 
appears to be the total count of bacteria. Other laboratory tests may also be found to be applicable, with special reference to dirt determination. Objections to dairy score requirements for the different grades have been discussed in Chapter III. The logical way to rate milk is by the quality of the product itself, not by the equipment of the dairy or the methods which the dairyman is believed to use. In short, the proof of the milk is the testing.

The most practical criterion of composition is the butter-fat percentage, which varies more than the solids not fat, is easy of determination, and is a point of particular importance in artificial infant feeding.

A natural application of the above considerations would be to grade milk according to sanitary quality as "Grade A," "Grade B," etc., with the use of the word "raw" or "pasteurized"; then to add a figure indicating for each supply the butter-fat percentage. This latter might be stated by limits of variation, e. g., " 3.5 to $4.0 \%$ fat," or by a single figure, as " $3.5 \%$ fat," with a legal limit as to the permissible variation of the actual content from such figure. Butter-fat labelling has not yet, so far as the writer knows, been attempted, but has been proposed ${ }^{*}$ and, if proved to be practicable, would be the logical way of selling milk according to richness. It would ensure the purchaser the desired amount of cream and, if sufficiently accurate, would be a guide for removing cream from milk in preparing it for infant feeding. At the same time, the health authorities would have to perform sufficient

* See recommendation by the Commission on Milk Standards, p. 92, which further advises a guaranty of milk solids not fat. 
testing and dealers would have to exercise care in mixing milks so that the fat percentages would correspond with the markings; otherwise these would only be misleading.

Under the grading system the producer is paid for the kind of milk that he produces, the dealer is paid for the kind or kinds that he sells, and the consumer pays for what he chooses to buy; and this result comes about largely automatically. Natural differences will be evident instead of being confused. The great mass of consumers will doubtless continue to buy the cheapest milk that they can, but an increasing public recognition of the better grades should develop when these are clearly labelled and their use advocated by health authorities. The system is therefore not merely punitive as regards bad milk but is a means of developing the production of good milks.

\section{The Public Value of Milks}

It is obvious that the availability of a given milk to the consumer depends not only upon its sanitary and food quality but also upon the price which he has to pay. Dr. Charles E. North has sought to combine the various items involved, by means of an ingenious method of rating the public value of different milks. Dr. North states that "the public value of milk, assuming that the average chemical composition of the different grades and classes on the market is about the same, depends chiefly on three fundamental characteristics. These are safety, cleanliness, and price." His method of rating, on a scale of 100 , is set forth in the following table:- 


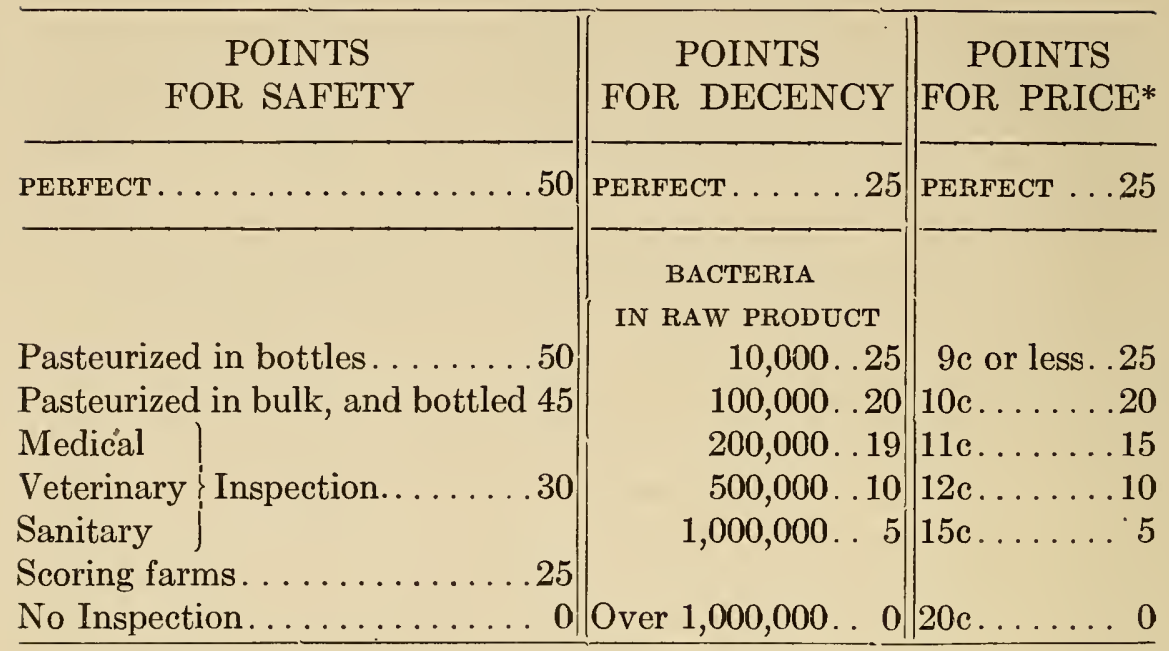

(Clarification would add 5 points to decency of all milk and in the case of raw milk would also add 5 points to safety.)

This scale, applied, for example, to the milks sold in New York City, gives values ranging from 89 down to 70 for the three market grades A, B, and C. Certified milk is valued at 60 , being rated down on safety and price, while ordinary raw milk, excluded from sale by the above grading, is given no credit except for price, having the low value of 25 . Dr. North states that "the milk of the future will be reasonably clean and scientifically pasteurized, and will be sold at a moderate price. Such milk as Grade A pasteurized at 9 or 10 cents per quart is the milk toward which the industry and the majority of sanitary authorities are now working." This method of rating and its implications are discussed by Dr. North in publications on the subject. ${ }^{1}$ It is obviously not to be taken too literally, but simply as making general comparisons between

* Price scale adjusted to prevailing market prices for bottled milks, minimum here being taken as 9 cents. 
established grades of milk more definite than would otherwise be possible.

\section{COSTS AND PRICES *}

Here may be summed up the main considerations relating to costs and prices. These may be conveniently shown as follows:-

\section{FACTORS}

Increasing farm costs of feeds, labor, and other necessaries

Agricultural inefficiency

Increasing distances and rates of transportation

Increasing city expenses of dealer Sanitation
Improvement of dairying methods

Greater efficiency of milk plant machinery and methods and of distribution (all favored by concentration)

Simplification of sanitary requirements

TENDING TO ADJUSTMENT OF COSTS AND PRICES

Recognition of grades

Organization of farmers

The above is simply a view of salient features with the omission of considerations as to supply and demand, adjustment of railroad rates, and other complicating factors.

Regarding the general level of milk prices, the impression got from considerations set forth in the last chapter is that, at time of present writing, costs are

* Cf. Appendix D, Costs and Prices. 
increasing distinctly more rapidly than the price to the consumer. Hence, while better methods in milk sanitation will tend to keep down costs, the consumer must expect, so long as these are actually increasing, to pay for the increase. If, as appears, a great deal of milk is now produced at little or no profit or even at a loss, and this is becoming increasingly recognized, then rising prices must naturally be looked for. Again, wherever materially stricter sanitary requirements are made, it is to be expected that a corresponding compensation in increased price will be demanded.

It is unreasonable to expect that, when the costs of staples and labor are rising, the price of milk should remain stationary, for the farmer and dealer are subject to the same economic conditions as the population in general. Regarding any increase in the retail price, it is fair to suppose that it should be shared by farmer and dealer. Up to the present the farmer appears to have had the small end of the division of profits. At the same time a legitimate increase in price paid to the producer should not serve as an excuse to dealers acting in concert or combination to raise unduly the price to the consumer. Unfortunately the present system requires retail prices to be stepped up or down by whole cents, while the dealer can adjust his price to the producer in small fractions.

As to the cost of sanitation considered separately, sanitary milk need not cost much more than unsanitary milk. Some idea of the items in this regard is given by the North system (page 78) and by some of the figures in Appendix D.

The advantages of the ticket system and of the ad- 
justment of retail prices by fractions of a cent have already been discussed in Chapter IV (pages 146-47).

Whatever price readjustments take place with the adoption of the grading system will normally be the just results of recognition of quality. In New York City Grade A milk sells at one cent a quart more than Grade B, while Grade C (an unbottled milk for cooking or manufacturing purposes) is two cents below B. It is clear that since proper grading in the average community, would raise standards, corresponding increases in prices might be expected, but these would fall chiefly or wholly on the better grades, and should be by no means excessive.

Finally, the system of grades, by clearing up confusion, permits freer play to the economic force of competition and to the economic law of supply and demand. There has been much talk about securing the coöperation of the dairyman and persuading him to go to trouble and expense for improvements which are not recognized in an increased price for his product over that of other diarymen less amenable to persuasion. Coöperation is an excellent thing, and it is well to encourage individual effort. But competition is, after all, the dominant force. It is not necessarily true that, as has been asserted, "commercial competition hurts the quantity and the quality of the milk supply." Quality is impaired only when sanitary regulation is so inadequate as to permit it to be. Establish and enforce definite milk standards for different grades, and competition should operate to produce each grade most efficiently and cheaply, while economic law should ensure that the supply of each approximate the de- 
mand,-although, to be sure, these effects are subject to modification by conditions of present-day milk industry which we have considered elsewhere.

\section{THE RÔLE OF THE LABORATORY}

In gauging the quality of milk the scientific method is to rely upon the indication of the laboratory as opposed to the less accurate indications of inspection. Reasons for this have already been set forth in Chapter III, in the discussion of the score-card method of dairy inspection. By means of inspection such matters as health of cows and methods of operating milk plants may be looked after, but, as regards operations in the dairy, it is seldom possible to observe them. Inspection is therefore chiefly a means of giving advice or instruction to the dairyman. But, by means of the laboratory, samples of a milk may be taken at any stage of its history and subjected to specific tests. These tests can disclose not only its general bacteriological and chemical character but also, perhaps, the quantity of dirt which has contaminated it, and can even detect abnormal udder conditions in the milch cow when physical examination of the animal would not do so.

Laboratory methods are steadily being developed in scope and exactitude. They must rightly be regarded not as a mere adjunct of inspection but as a first means of indicating where inspection-or rather instruction-is needed.

A recent paper by Dr. Charles E. North, arguing cogently for proper correlation of laboratory and inspection work, and putting the laboratory test before 
the inspection, along the line from city to country, concludes as follows (italics inserted):-

In forming plans for the expenditure of the annual appropriation for milk control the milk dealer as well as the health officer should bear in mind that one laboratory worker can test the milk of fifty dairy farms for bacteria while one dairy inspector is inspecting five dairy farms, and that therefore one dollar spent in laboratory testing covers as much territory as ten dollars spent in dairy inspection. The laboratory test should come first and make the diagnosis; the dairy inspector should come second and apply the remedy. These principles result in the greatest economy and efficiency, whether control is being exercised by the milk dealer or by the health officer. ${ }^{2}$

\section{THE RÔLE OF INSPECTION}

Inspection seems to have been originally regarded as a species of policing, often with the elements of detective work. The object was to "catch" the bad milkman. This idea has now been largely superseded by that of advice, of "education of the dairyman."

\section{Dairy Demonstration}

The conclusion toward which modern milk control is tending is this: if the product, the milk itself, is to be judged, rather than the dairy, and the dairyman understands that its resultant bacterial character is the all-important thing, then he will welcome advice which will help him to produce better milk. If he be held responsible and be paid for good results, he will practice the methods for getting them.* And if those

* Under the North system (p. 78) it was stipulated that the dairyman 
methods be simplified to the greatest possible degree, so that he is not confused and discouraged by minutiæ, then his coöperation will be completely secured.

All of this has been shown to be perfectly possible by North's methods (described in Chapter III, where also the use of a new type of score card was discussed). Mere inspection as a mode of regulation has certain serious inherent difficulties. The usual impossibility of being present at milking time and other times when operations connected with milk are going on has made inspection often a mere survey of premises and equipment. Questioning and injunctions do not ensure that the dairyman use specified utensils and methods. A small-topped milking pail on the wall may mean nothing. But if the dairyman is directly responsible for the bacterial content of his milk, he will not wisely shirk methods as he is tempted to do when the emphasis is placed on inspection.

Under these circumstances inspection, far from being the bane of the farmer, would be indispensable to him. Its frequency would be governed by the results of laboratory tests. It would be largely instructional; the inspector would be an adviser or demonstrator of methods. The idea of inspection proper would of course apply to such special examinations as may be required, taking of samples, surveillance of milk plants and of the sale of milk, and similar functions. And when methods are to be criticised, advice or warning on the basis of unfavorable bacteriological tests will carry far more weight than any made "in the air."

should share his sanitary premium with his milkers, thus carrying the principle of payment for results to its logical extent in this direction. 
A sane milk supply [says a recent writer] must be cheap enough to be within reach of the common people; for this purpose certified milk is a failure; on the contrary, if dairy demonstration supersedes dairy inspection, and laboratory tests the score card in grading milk, when care is made superior to equipment . . . then a clean milk may be had at a reasonable price as well. ${ }^{3}$

\section{ORGANIZATION AND ADMINISTRATION *}

The ideal plan for the administration of milk laws would combine local and state supervision. Sanitary authority being primarily local in nature, local municipalities should have ample power to control their milk supplies; but there are certain things outside of their territorial limits that can be done more efficiently by the state. Local control has developed in advance of that of the state, but the tendency is now toward giving greater powers of supervision (not abridging, but supplementing, those of local municipalities) to state authorities. Local authorities could, under proper organization, enforce their ordinances through the coöperation of the latter, who would thus exercise supervision but not actual control. Modern laboratory methods fortunately enable each municipality (provided laboratory facilities are adequate) accurately to gauge the quality of milk as it is received within its limits. "Country work" by state authorities is an advantage for the reasons that they may economically district their territory, that reduplications and long trips by local officials may be avoided, that supplies rejected by one municipality may be prevented from

* Cf. following section, on Legislation. 
going to another without detection, and that uniformity of methods may be secured and friction eliminated. Supplies originating in one State and sent to neighboring States for sale may be supervised by officials of the latter on condition of not being allowed entry to the State without approval of their quality and treatment and access of such officials to the sources and the line of transportation. Theoretically, the state might best perform all the necessary supervision outside of the limits of each municipality.* But many municipalities do all or a great deal of such work, for state control is undeveloped and immediate expediency has dictated such activity.

The state authorities referred to are those dealing with health and with agriculture and animal industry.

One problem [says Dean Russell of the Wisconsin College of Agriculture] which so far has not received the attention which it should is the correlation of the work which should be performed by the state. At present three generally unrelated state organizations may be concerned with the milk problem:

(1) State boards of health, which are directly interested in public health problems.

(2) State live-stock sanitary boards, or live-stock commissions, which are concerned with the control of animal diseases.

(3) State dairy and food commissions, which control the purity and wholesomeness of food supplies.

Too frequently there is no correlation in the work of these respective bodies. The milk problem touches all three of

* This principle was endorsed by the New York Milk Committee in 1913, in a plan advocating uniform state legislation fixing milk standards. 
them, with none of them is it a dominant phase of their activity. The consequence is that the problem in its entirety does not receive the adequate attention of any of them. In this respect improved conditions would undoubtedly obtain, if a more thorough correlation of these various organizations could be brought about.

The milk problem, as such, is properly a hygienic matter. Under these conditions, there is no question but that the public health organization is in a better position to exercise more effective control than either of the other two. ${ }^{4}$

The work of Federal authorities in this field is chiefly advisory, consisting in investigation, advice to States and communities, and publication of information of more or less general application.

The situation as to state control is commented upon by Dr. Charles V. Chapin, in a recent survey of the work of state health departments, as follows:-

The subject of milk control is one of the most complicated and difficult in the whole field of public health. There are some who feel that it is a local problem and should be left to the municipalities to work out for themselves. The majority believe theoretically in uniform state laws and state control, but these are difficult of attainment. In agricultural states, with small cities, the difficulties are not so great, and they are most acute in the northeastern states, where there are many large cities and less good agricultural land. Theoretically, the State Board of Health should be entrusted with the enforcement of milk laws, as well as consulted in their framing. Actually, state legislatures have not given the State Board of Health much authority, owing to fear on the part of the farmers. In some states it is claimed that authority over milk has been given to the department of agriculture, to keep it away from the health department, or 
a special dairy department has been created for a similar purpose. $^{5}$

The development of extension work by state agricultural authorities is of the greatest importance. It is not sufficient to publish scientific bulletins; the most effective service requires that agricultural experts-advisers or demonstrators - go regularly to the farmer and assist him with his problems. In preceding paragraphs we have seen how important is this practical advice as distinguished from mere inspection and how it is a necessary complement of milk regulation

\section{LOCAL SUPERVISION}

Granted that efficient public health service and a system of grading have been established, the most important single means of local supervision is the laboratory. The apparatus for performing even as many as 100 to 200 bacteria tests daily can be installed at a small expenditure (\$200 to $\$ 500){ }^{6}$. (The apparatus for ordinary chemical tests is also inexpensive.) Under expert supervision, tests may be made by a careful worker (young man or woman) at a very moderate salary.

The effort should be made to examine each supply for total count at least once a week, especially during the warmer months, and to make any special examinations that may be necessary.* Chemical tests may be made less frequently, unless milks are labelled for fat content. Other laboratory tests, e. g., for dirt, may also be practiced.

The amount of attention devoted to milk supply by

* Cf. resolution of Commission on Milk Standards relative to tests for grading, Appendix B. 


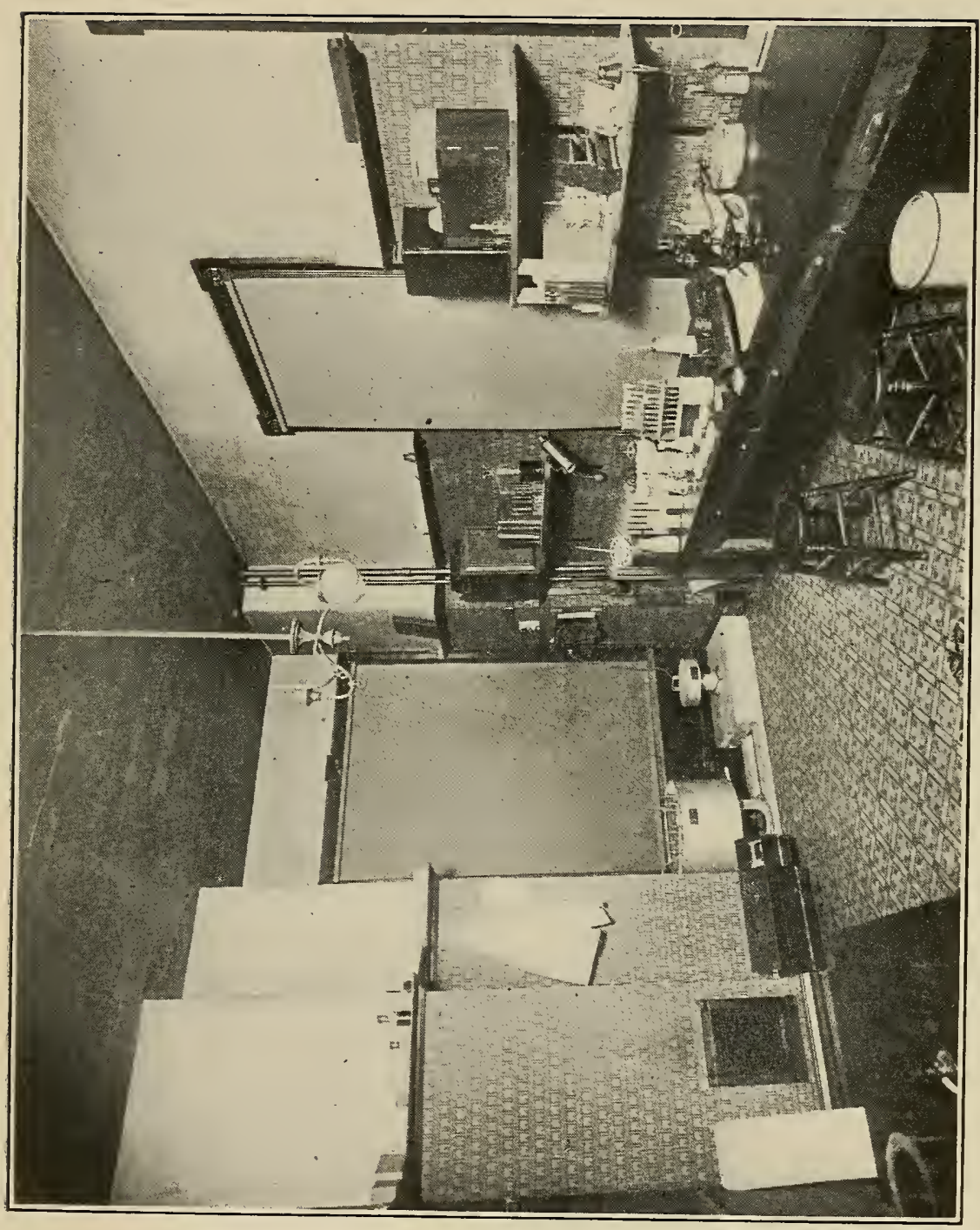

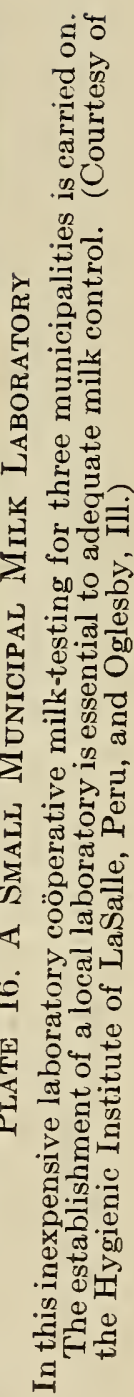



local health authorities varies greatly. Information collected by the Department of Agriculture in 1912-13 from 162 cities of the United States showed that the amount of money spent for dairy inspection ranged all the way from nothing to 19 cents per capita per annum, with an average of 3.6 cents. But, beyond the mere fact that the amounts were spent, we know nothing as to the methods, efficiency, or results accomplished.

Coöperative Local Supervision.-In connection with local work mention must be made of the fact that communities which are too small to be able to afford adequate milk control, and especially the laboratory at which it should center, may coöperate in maintaining a common laboratory and joint service. Such coöperation is in effect at Wellesley, Mass., with a number of neighboring towns, at La Salle, Oglesby, and Peru, Ill., where a common Hygienic Institute, or health department, has been established; and among the municipalities centering about Orange, N. J. In the first two cases the coopperation is for public health service in general, while in the last case it is simply for supervision of milk supplies. It is obvious that such plans not only simplify and economize the control of overlapping milk supplies, but also make it possible for even the smallest of the towns concerned to obtain expert service and adequate laboratory facilities at a moderate cost.

\section{LEGISLATION}

What has been said in the preceding section foreshadows the remarks appropriate to this head. While the sanitary function of milk regulation is primarily a 
local matter, there is now a tendency to make state legislation more specific and to give the state board of health or some other body power to promulgate regulations applying to the state as a whole, excepting, perhaps, the largest cities. Such legislation and regulations may ensure uniformity of fundamental requirements, and are a special manifestation of the general tendency to establish state sanitary standards. A notable step in this direction has been taken in New York State, where a sanitary code prescribed by the Public Health Council applies throughout the State with the exception of New York City. (For the system of milk grading established by this code, see Appendix B.) A similar power has also been conferred upon the State Board of Health of New Jersey.

Legislatures may embody more or less specific regulation in statute, leaving subordinate regulations to some special body, or they may confer large general powers in the matter to such a body. The normal agency for the formulation of state regulations primarily affecting public health is the state board of health, but, on account of the several interests involved, there has been some controversy as to what body should be empowered to prescribe milk regulations. Composite boards or commissions have, therefore, been proposed in which health and agricultural authorities should play the chief part, along with representatives of local boards of health, farmers' and dealers' organizations, etc. It seems clear, however, that the sanitary authorities should alone be vested with power to establish regulations primarily affecting health. A mixed board, especially if at all large, is likely to be a disharmonious 
and therefore a weak board. The practical effect of such a board is likely to be to obstruct if not to nullify the efforts of the health authorities. Compromises are the result of undue jealousy on the part of agricultural and milk industry interests, which cannot in justice oppose legitimate sanitary control under proper legislation.

\section{LOCAL DIFFERENCES}

Local or regional differences in the intensity of the milk problem are determined by the following general factors:-

1. Degree of urbanization and of development of milk traffic.

2. Value of agricultural lands.

3. Development of efficiency of the dairying industry.

4. Costs of feeds and other farm material, of farm labor, transportation, handling, and distribution.

5. Sufficiency or insufficiency of local milk supply.

6. Sanitary control or its absence.

7. Adjustment or maladjustment of milk prices.

These factors naturally vary greatly according to place, and certain of them fluctuate from month to month. A complete survey of the milk situation of a region or city is a matter of much complexity. Mention of some such surveys is made in Appendix E.

To establish sanitary control in any given town or city, extensive preliminary investigation is usually unnecessary. Chief attention is to be paid to the question of how much laboratory and inspection work is necessary for the given number of supplies, dairy farms, 
milk plants, etc., and its cost. Facts well recognized regarding the milk problem in general should be assumed. It is well to bear in mind that some local data have primarily an administrative value, while others are assembled chiefly in order to convince governing and appropriating bodies of the necessity of control. In proposing regulation the recommendations of the National Commission on Milk Standards should be consulted. In establishing the grading system it is of course necessary to specify a thorough working mechanism as a prerequisite to the proper enforcement of the system.

\section{CENTRALIZATION, COÖPERATIVE PLANS, MUNICIPALIZATION}

The difficulties, sanitary and economic, of the milk problem under present trade conditions are such that various plans for centralization and coöperation have been proposed. These may be classified as follows:-

1. Farmers' coöperative milk depots in country districts.-Such a plan has been described by the Boston Chamber of Commerce committee as quoted on pages 142-44 of the present volume. Under this head may also be included plans for the organization of such depots under the auspices of city organizations, as in the case of the Homer plan (Appendix C).

2. Farmers' coöperative city marketing, involving sale of milk by bidding or auction to city dealers, with the object of breaking up price-dictation by middlemen. This has recently been proposed by New England producers shipping milk to Boston. 
3. Coöperative pasteurization plants, under private or public control.

4. Central city delivery, under private or public control (see pp. 139-40).

5. Complete municipalization,-i. e., handling under the control of the municipality from the farm to the consumer. This plan has recently been proposed for all municipalities in the State of Rhode Island by a legislative commission of inquiry (Appendix E).

Concentration is clearly a great factor in efficiency, as is shown by the large milk companies of the cities. Individual retailers, as well as the farmers, have been slow to see the great advantage of concentration; hence they labor under difficulties. Farmers' coöperative milk depots in country districts have been advocated as practical (see pp. 142-44). Coöperative pasteurization and central distribution to obviate the wasteful overlapping of delivery routes have been tried in one instance known to the writer, with apparent success (see p. 250). Certain practical difficulties are to be met in connection with these last ideas,-difficulties which could be obviated only by amalgamation or assumption of the interests of the dealers involved (see p. 140). The association of individual dealers to form businesses of efficient size would eliminate the disadvantages and wastes existing when bottling, pasteurization and distribution are so dispersed that overlapping of function and high operating expenses are inevitable. There is more hope in the general recognition of this economic fact by dealers and in their voluntary or economically forced amalgamation of interests than in coöperative plans which have to 
contend with the individualistic attitude of retailers in competition.

Those who advocate the extreme of municipalization-for instance, Nathan Straus ${ }^{7}$-draw a parallel between water supplies and milk supplies, and argue that, as municipalities have had to own the former, so they will have to come to owning the latter. The basis of the parallel is that milk, like water, is distributed in larger quantities and bears an important relation to public health, and that milk supply cannot be satisfactorily controlled by public authority acting in a simply supervisory capacity. The mere condemnation of the idea as "socialistic" is, of course, superficial; it should be examined on its actual desirability.

The proposition comes into relation with the general idea of municipal management of public utilities. It may be taken as a principle of political economy that such management, in general, should not be undertaken unless public regulation has proved to be a failure. Such failure is most likely to occur in connection with monopolies, and the argument is strongest in the case of natural monopolies, such as water supply. But in the case of milk supplies, monopoly is seldom advanced as a reason, the proposal of municipalization being based upon desired expediency of regulation or efficiency of operation.

As a general principle, "reasonably successful regulation," writes the economist Taussig, " "is more easy to attain than reasonably successful public management," and under conditions in the United States there has been a marked and justifiable tendency to rely upon private enterprise for the performance of even 
distinctly public services of an industrial character. The supplying of water to town and city dwellers has been (as another economic authority ${ }^{9}$ says) "the only important exception ... and this has been undertaken by municipal governments less because of any distrust of private enterprise in this field than because good water has been demanded by public opinion even before the business of supplying it gave promise of proving financially successful." The writer just quoted also cautions us that, in general, "the objections to such policy [municipal ownership or management] for the cities of the United States are very strong." 10

In point of actual operation the public assumption of the milk trade, especially by large cities, would obviously involve serious difficulties not found in the simple taking-over of a water system. In view of the fact that there are as yet (so far as the writer knows) no data of the actual operation of any such plan, caution is certainly justified. The immediate embarrassment arising from disturbance of the milk trade must be considered, as well as the possible evils of political control. The debate between those who believe that the difficulties of the milk problem can thus be swept away at a stroke and those who hold that satisfactory public supervision is not only possible but safer and more favorable to efficiency than public management would be, is not unlikely to issue into some trial of the idea.* Auspicious conditions for this might possibly

* The author has not been able to obtain any information as to whether the idea of municipalization has been put into practice anywhere in the United States. At Jamestown, N. Y., however, a plan has been under consideration (Western Medical News, June, 1915). Municipal milk plants, mainly for pasteurization, have been proposed 
be found in a well-governed municipality, of the smaller size, where the town functions of individual farmerretailers could readily be assumed by the municipality without serious disturbance. In instances where the question of the tuberculin test is being agitated, farmers might prefer to sell to a coöperative or municipal pasteurizing and distributing plant rather than undertake the test. Such a plant might possibly be financed and managed by an association of citizens with the object of securing better milk and eliminating inefficiency in distribution, as an alternative to municipal management. In short, as with some other proposals of coöperation or municipalization, exceptional local conditions might perhaps render such a project feasible. But the sweeping claims attached to the general idea must certainly be viewed as extravagant.

\section{THE GIST OF THE MATTER}

To sum up the salient factors in the solution of the problem:-

Milk must be both safe and decent.-It should also be of known food value.

To secure Decency: Supplies should be controlled by laboratory tests supplemented by inspection in which instruction in simple, rational methods of clean milk production should play the chief part.

in several instances. The Health Officer of Brookline, Mass., makes such a proposal in a recent report. The most conspicuous plan of municipal management is that recently proposed by a legislative commission in Rhode Island (see Appendix E). It is interesting to note that even a socialist, John Spargo, while accepting the theory of socialization of milk supplies, has not favored attempting to apply it under American. conditions ("The Common Sense of the Milk Question," 1908). 
To secure Safety: All milk, excepting possibly a class of the highest grade, should be pasteurized under adequate official supervision.*

To secure Justice: Milk should be graded and labelled on the basis of laboratory tests and pasteurization.

Grading and the laboratory are the most important single means of sanitary control.

Grading is the most important single factor in economic adjustment.

Quality should be recognized through fair milk prices to both farmer and dealer.

The advantages of centralizing at a few plants the operations of handling, pasteurization, bottling, and distribution should be recognized.

\section{WHO IS TO SOLVE THE PROBLEM?}

While the various factors in the milk problem sometimes appear to have reached a pass which may be described as a puzzle, a deadlock, or a "muddle," its solution should not be so difficult as it often seems, provided only that facts be recognized and right principles adopted. It will not, however, be lastingly solved by any one group of persons without regard to the others concerned.

Health authorities must adopt improved methods of sanitation and, with legislative sanction and support, establish rational regulation based upon the grading principle.

* It may here be again noted that, although the recommendations of the National Commission on Milk Standards leave the pasteurization of "Grade A" milk optional, the majority of the commissioners voted in favor of the pasteurization of all milk. 
Legislators must recognize the necessity of legislation authorizing such regulation, as opposed to the dangers of inaction or partisan interest.

Agricultural authorities must advise the farmer in the methods of producing sanitary milk efficiently.

The dairy farmer must welcome this assistance and make use of all possible means of improving his methods and management, and he must organize.

The dealer must respect the interests of the farmer, work for the solution of their common problems, and pay a fair price for milk according to quality.

The consumer, finally, must recognize quality in milk; he must be willing to pay a fair price for good milk and a reasonably higher price for better milk. 


\section{REFERENCES}

(References are given for the more important matters cited in the text, but no attempt has been made to make the list exhaustive.)

\section{Chapter I. Why There is a Milk Problem}

1. Sedgwick, Wm. T., "Principles of Sanitary Science and the Public Health," New York: The Macmillan Co., 1905, p. 263.

2. Farmers' Bulletin 363, 1910 (reprint, 1915), pp. 33-35.

3. Ibid., p. 7.

4. North, C. E., "Safeguarding Nature's Most Valuable Food, Milk," pamphlet prepared for the New York Milk Committee, 1915. Cf. note, "The bacteriology of milk from normal udders," Jour. Am. Med. Assn., 1916, vol. LXVI, p. 1930.

5. U.S. Children's Bureau, "Baby-saving Campaigns," 1913, p. 45.

6. Park, Wm. H., and Holt, L. R., "Report upon the results with different kinds of pure and impure milk in infant feeding in tenement houses and institutions of New York City: A clinical and bacteriological study," Archives of Pediatrics, Dec., 1903.

7. Meigs, Grace. (Children's Bureau, U. S. Dept. of Labor), "Other factors in infant mortality than the milk supply, and their control," Am. Jour. Public Health, 1916, vol. VI, p. 847.

8. "Milk and Its Relation to the Public Health," Bull. 56, Hyg. Lab., U. S. Public Health Service, 1909, p. 25.

9. Rosenau, M. J., "The Milk Question," Boston: Houghton Mifflin Co., 1912, p. 90.

10. Biggs, H. M., "Milk-borne septic sore throat-a new public health problem," Medical Record, Dec. 4, 1915.

Davis, D. J., "Milk epidemics of septic sore throat in the United States and their relation to streptococci," Science, Nov. 13, 1914, p. 1037.

MacNutt, J. S., "A Manual for Health Officers," New York: John Wiley and Sons, Inc., 1915, p. 288. 
11. Park, Wm. H., "The rôle of bovine tuberculosis in the production of human tuberculosis," Trans. XV Internat. Congress on Hyg. and Demography, 1912, vol. IV, pp. 267-72.

12. Rosenau, M. J., "Preventive Medicine and Hygiene," New York: D. Appleton and Co., 1913, pp. 124-25.

13. Ibid., p. 124.

14. Rosenau, M. J., "The Milk Question," p. 97.

15. Goler, G. W., 2d Ann. Trans. Am. Assn. for Study and Prev. of Infant Mortality, 1911.

16. North, pamphlet cited.

17. Kelley, Eugene R.: "The evidence available as to the relative importance of milk as a means of transmission of communicable diseases, compared with other means of transmission," Rpt. of Special Milk Board of Mass. State Dept. of Health, 1916; "The quantitative relationship of milk-borne infection in the transmission of human communicable diseases," Jour. Am. Med. Assn., 1916, vol. LXVII, p. 1997.

Chapter II. The Case To-day

1. Sedgwick, op. cit., pp. 271-72.

2. Rosenau, "The Milk Question," pp. 19-20.

3. Parker, H. N., "The city milk trade," Nat. Mun. Review, Oct., 1913, p. 737.

4. Cook, L. B., "The encouragement of clean milk production," Circ. 38 (from 62d Ann. Rept.), Mass. State Bd. of Agriculture, 1915.

5. Rosenau, "The Milk Question," pp. 243-44.

6. Parker, loc. cit.

7. Conn, H. W., "Will any milk do?", Harper's Weekly, Feb. 8, 1913.

8. Luening, F. W., Deputy Health Commissioner, Milwaukee: personal communication.

9. Chapin, C. V., "Effective lines of health work," Providence Medical Jour., Jan., 1916.

10. Chapin, personal communication, Sept. 29, 1916.

11. Schneider, Franz, Jr., "Relative values in public health work," Am. Jour. Public Health, Sept., 1916.

12. Boston Transcript, March 3, 1916. 


\section{Chapter III. The Sanitary Factors}

1. Parker, loc. cit.

2. Sedgwick, op. cit., p. 265.

3. Boston Med. and Surg. Jour., vol. 126, 1892, p. 25. (Quoted in Bull. 56, Hyg. Lab., U. S. Public Health Service, p. 450.)

4. Kelley, Ernest, "Medical milk commissions and certified milk," Bull. 1, U. S. Dept. of Agriculture, 1913.

Coit, Henry L., "The work of medical milk commissions . . . ," Trans. XV Internat. Congress on Hyg. and Demography, 1912, vol. IV, p. 611.

"Methods and standards for the production and distribution of "certified milk," adopted by the Am. Assn. of Med. Milk Commissions, 1912: Reprint 85 from Public Health Reports.

5. Brew, James D., "Milk quality as determined by present dairy score cards," Bull. 398, N. Y. Agric. Experiment Station, Geneva, N. Y., 1915.

6. Harris, J. A., Science, Oct. 8, 1915, p. 503.

7. Brainerd and Mallory, "A study of the bacterial count and dairy score card in city milk inspection," Bull., Virginia Polytechnic Institute, Sept., 1911.

8. Harding, Ruehle, Wilson, and Smith, "The effect of certain dairy operations upon the germ content of milk," Bull. 365, N. Y. Agric. Experiment Station, Geneva, N. Y., 1913.

9. Ibid.

10. North, "A Survey of dairy score cards," Am. Jour. Public Health, 1917, vol. VII, p. 25.

11. North, "Sterilizing stations in dairy districts," Jour. Am. Public Health Assn., 1911, vol. I (o. s. VII), p. 654.

12. North, "The market value of cleanliness in milk production," address delivered at 36th Ann. Convention, N. Y. State Dairymen's Assn., 1912.

13. North, "Bacterial testing versus dairy inspection, Am. Jour. Public Health, 1916, vol. VI, p. 572.

14. See 10.

15. "Infant mortality and milk stations," special report of Committee on Reduction of Infant Mortality, of the N. Y. Milk 
Committee, 1912; Kerr, J. W., "Data regarding operations of infants' milk depots in the United States in 1910," Reprint 64 from Public Health Rpts.; and many other sources.

16. Am. Food Jour., Aug., 1907, p. 33. (Quoted in Bull. 56, Hyg.

Lab., U. S. Public Health Service, 1909, p. 380.)

17. Reprint 141 from Public Health Rpts., 1913.

18. Reprint 192 from Public Health Rpts., 1914.

19. See 17.

20. Reprint 295 from Public Health Rpts., 1915.

21. Weinzirl, John, "A safe and sane milk supply," read in Jan., 1916, before Subsection D-IV, Sec. VIII, Pan-American Scientific Congress; to be printed by the Congress.

22. Campbell, H. C., "Comparison of the bacterial count of milk with the sediment or dirt test," Bull. 361, U. S. Dept. of Agriculture, June 29, 1916.

23. Wells, C. H., "The successful efforts of a small city to secure a milk supply from tuberculin-tested cows," Am. Jour. Public Health, 1912, vol. II, p. 703.

24. Reprint 141 from Public Health Rpts., 1913. Cf. bulletins relating to pasteurization published by U. S. Dept. of Agriculture.

25. Reprint 141 from Public Health Rpts., 1913.

26. Jordan, E. O., "The case for pasteurization," Trans. XV Internat. Congress on Hyg. and Demography, vol. IV, p. 627; Ayers, S. H., "The present status of the pasteurization of milk," Bull. 342, U. S. Dept. of Agriculture.

27. Kilbourne, Chas. H., "The Pasteurization of Milk from the Mechanical Viewpoint," New York: John Wiley and Sons, Inc., 1916. (The dealer contemplating pasteurization or improvement of methods will find this book of advantage in comparing different types of commercial pasteurizing machinery.)

28. "The value of boiled milk," editorial, Jour. Am. Med. Assn., 1916, vol. LXVII, p. 1674.

29. Ayers, S. H., and Johnson, W. T., Jr., "Pasteurization in bottles and the process of bottling hot pasteurized milk," Jour. Infectious Diseases, 1914, vol. XIV, p. 217.

30. Sedgwick, Wm. T., "American achievements and American 
failures in public health work," Am. Jour.Public Health, 1915, vol. V, p. 1105.

31. Bahlman, Clarence, "Milk clarifiers," Am. Jour. Public Health, 1916, vol. VI, p. 854.

32. Baldwin, H. B., "Some observations on homogenized milk and cream," Am. Jour. Public Health, 1916, vol. VI, p. 862.

\section{Chapter IV. The Economic Factors}

1. Cook, L. B., loc. cit. under Ch. II.

2. Boston Transcript, March 8, 1916.

3. Clean Milk Bulletin (Charles E. North), Dec., 1911.

4. Editorial, Jacksonville, Fla., Times-Union, March 6, 1913.

5. Kelly, Ernest, "Factors influencing the cost of milk to the consumer," Hoard's Dairyman, April 24, 1914.

6. Bull. 156, U. S. Bureau of Labor Statistics, March, 1915; Monthly Review, same Bureau, vol. II, no. 6, June, 1916.

7. Kelly, loc. cit.

8. Kelly, loc. cit.

9. Cook, loc. cit.

10. Williams, John R., "The economic problems of milk distribution in their relation to the public health," Trans. $X V$ Internat. Congress on Hyg. and Demography, 1912, vol. V, p. 128.

11. Report on Milk Investigation, Boston Chamber of Commerce, 1915, p. 32 ; cf. p. 61.

12. Ibid., pp. $49 \mathrm{ff}$.

13. Bull. Vt. State Bd. of Health, Dec. 1, 1916.

\section{Chapter V. How Solve the Problem?}

1. North, C. E., "The public value of different milks," Med. Record, Nov. 22, 1913; "Safeguarding Nature's Most Valuable Food-Milk," booklet issued by N. Y. Milk Committee, 1915.

2. North, "Bacterial testing versus dairy inspection," Am. Jour.

Public Health, 1916, vol. VI, p. 578.

3. Weinzirl, op. cit. under Ch. III.

4. Russell, H. L., "The function of the state in milk-control 
work," Trans. XV Internat. Congress on Hyg. and Demography, 1912, vol. IV, p. $600 \mathrm{f}$.

5. Chapin, C. V., Report on State Public Health Work, based on a survey of state boards of health, Am. Med. Assn. (n. d., 1915 or 1916), p. 171.

6. North, loc. cit. (2), p. 573.

7. Straus, Nathan, "The relations of the city to the milk supply," Am. Jour. Public Health, 1915, vol. V, p. 11.

8. Taussig, F. W., "Principles of Economics," New York: The Macmillan Co., 1913, p. 413.

9. Seager, H. R., "Introduction to Economics," New York: Henry Holt and Co., 1906, p. 457.

10. Seager, "Economics: Briefer Course," 1909, p. 368.

\section{General References}

Although the literature of milk is very voluminous, there are few good books on the subject. Most of the vital information is scattered through periodical and bulletin literature such as that to which the preceding references relate.

The most valuable single item is the reports of the National Commission on Milk Standards appointed by the New York Milk Committee (105 East 22d Street, New York City), which contain important recommendations concerning grading and regulation of milk and milk products.

A comprehensive work dealing with the various phases of milk industry and methods of control, by Horatio N. Parker, has recently appeared: "City Milk Supply" (McGraw-Hill, 1917).

One of the best general works, non-technical, is Rosenau's "The Milk Question" (Houghton Mifflin, 1912).

"Milk and the Public Health," by W. G. Savage, an English authority who quotes freely from American sources (Macmillan, 1912), is an excellent summary of professional milk literature up to that date. This work deals with the bacteriology and bacteriological examination of milk, milk and human disease, and control of milk supplies. A still more recent work, also English, of the same character, is "Milk and Its Hygienic Relations," by Dr. Janet E. Lane-Claypon (Longmans Green, 1916). 
In 1908 the Hygienic Laboratory of the United States Public Health Service published a large volume entitled "Milk and its Relation to the Public Health," embodying monographs on the various phases by different collaborators. This was revised and enlarged and republished as Bulletin No. 56 of the Laboratory, 1909. Bulletins on various subjects relating to milk and to dairy husbandry and industry are constantly being published by the United States Public Health Service, by the United States Department of Agriculture, and by state departments of agriculture and experiment stations. Papers and notes appearing in such journals as are mentioned in the foregoing bibliography may also be consulted for current developments.. 



\section{APPENDIX A}

\section{SOME MILK STATISTICS}

\section{GENERAL ESTIMATES FOR THE UNITED STATES *}

Total annual production of milk (1915)

$11,590,000,000$ gallons $\uparrow$

(115 per capita)

Value of the same, on the farms......... $\$ 2,320,000,000$ Milch cows on farms (Jan. 1, 1916) . ...... 21,988,000 Value of the same.............. \$1,185,119,000 Average yield per cow...........537 gallons per year Average per capita use of milk as such.. 0.6 pints per day

* Drawn from Monthly Crop Report, U. S. Dept. of Agriculture, vol. 2, no. 1, Jan. 31, 1916.

$\dagger$ Of this the larger part is used for the manufacture of butter, cheese, condensed milk, and other milk products. The proportion consumed as milk is estimated as about one-quarter of the whole. 
Population and Milch Cows in the United States. Compiled and computed from the U. S. Census and the Yearbook of the U. S. Department of Agriculture for 1915. (Except as otherwise noted, figures relate to January 1 of each year.)

\begin{tabular}{|c|c|c|c|c|}
\hline Year & $\begin{array}{l}\text { Population of } \\
\text { continental } \\
\text { United States }\end{array}$ & Milch cows & $\begin{array}{l}\text { Milch cows } \\
\text { per } 1,000 \text { of } \\
\text { population }\end{array}$ & $\begin{array}{l}\text { Average } \\
\text { price per } \\
\text { head }\end{array}$ \\
\hline 1880 . & $* 50,155,783$ & * $12,443,120$ & $\ddagger 248$ & $\$ 23.27$ \\
\hline 1890. & $* 62,947,714$ & * $16,511,950$ & $\ddagger 263$ & 22.14 \\
\hline 1900. & $75,451,000$ & $16,292,000$ & 216 & 31.60 \\
\hline 1900. & * 75,994,575 & * 17,135,633 & $\ddagger 225$ & $\ldots$ \\
\hline $1901 \ldots$ & $76,938,000$ & $16,834,000$ & 219 & 30.00 \\
\hline 1902. & $78,556,000$ & $16,697,000$ & 212 & 29.23 \\
\hline $1903 \ldots$ & $80,174,000$ & $17,105,000$ & 213 & 30.21 \\
\hline $1904 \ldots$ & $81,792,000$ & $17,420,000$ & 213 & 29.21 \\
\hline $1905 \ldots$ & $83,410,000$ & $17,572,000$ & 211 & 27.44 \\
\hline $1906 \ldots$ & $85,028,000$ & $19,794,000$ & 233 & 29.44 \\
\hline 1907. & $86,646,000$ & $20,968,000$ & 242 & 31.00 \\
\hline $1908 \ldots$ & $88,264,000$ & $21,194,000$ & 240 & 30.67 \\
\hline $1909 \ldots$ & $89,882,000$ & $21,720,000$ & 242 & 32.36 \\
\hline 1910. & $91,500,000$ & $21,801,000$ & 238 & 35.29 \\
\hline 1910. & $\dagger 91,972,266$ & $\dagger 20,625,432$ & $\ddagger 224$ & \\
\hline $1911 \ldots$ & $93,118,000$ & $20,823,000$ & 224 & 39.97 \\
\hline $1912 \ldots$ & $94,736,000$ & $20,699,000$ & 219 & 39.39 \\
\hline $1913 \ldots$ & $96,354,000$ & $20,497,000$ & 213 & 45.02 \\
\hline $1914 \ldots$ & $97,972,000$ & $20,737,000$ & 212 & 53.94 \\
\hline $1915 \ldots$ & $99,590,000$ & $21,262,000$ & 213 & 55.33 \\
\hline $1916 \ldots$ & $101,208,000$ & $21,988,000$ & 217 & 53.90 \\
\hline
\end{tabular}

* Census as of June 1.

$\dagger$ Census as of April 15.

$\ddagger$ At date of census. 
Milch Cows, By States: 1905; 1915, and 1916. Fundamental figures are taken from Yearbooks of the U.S. Department of Agriculture for 1904, 1914, and 1915.

(Numbers represent thousands, estimated for January first of each year.)

\begin{tabular}{|c|c|c|c|c|c|}
\hline & 1905 & 1915 & $\begin{array}{l}\text { Increase } \\
\text { (per cent })\end{array}$ & $\begin{array}{l}\text { Decrease* } \\
\text { (per cent })\end{array}$ & $1916^{*}$ \\
\hline Maine... . & 189 & 157 & & 17 & 159 \\
\hline New Hampshire. . & 130 & 95 & & 27 & 97 \\
\hline Vermont..... . & 285 & 268 & & 6 & 273 \\
\hline Massachusetts & 191 & 157 & & 18 & 155 \\
\hline Rhode Island. . & 25 & 23 & & 8 & 22 \\
\hline Connecticut. & 131 & 118 & & 10 & 119 \\
\hline New York. & 1,722 & 1,509 & & 12 & 1,539 \\
\hline New Jersey. . & 185 & 146 & & 20 & 152 \\
\hline Pennsylvania. . & 1,087 & 943 & & 13 & 971 \\
\hline Delaware..... & 35 & 41 & 17 & & 42 \\
\hline Maryland. & 147 & 177 & 20 & & 181 \\
\hline Virginia. & 153 & 349 & 128 & & 359 \\
\hline West Virginia. . & 180 & 234 & 30 & & 241 \\
\hline North Carolina & 193 & 315 & 63 & & 321 \\
\hline South Carolina... & 110 & 185 & 68 & & 189 \\
\hline
\end{tabular}

* In considering the exact significance of the movements shown in this table, the ratio between the estimated number of milch cows and the estimated population of the state at each date should be taken into account. Thus relatively to population, several other States-e. g., Illinois-would be placed in the group showing decrease as between 1905 and 1915. Figures on actual production of milk in the years taken are not available, but the question of productivity may be disregarded in considering the general phenomena brought out by the table.

$\dagger$ This column is added to show the recent trend, as between 1915 and 1916. It will be observed that those States which showed a decrease during the preceding decade have now (and perhaps had before the close of the decade) entered a period of increase, with the exception of Massachusetts and Rhode Island. In Connecticut, however, this increase appears to be less than proportionate to the increase in population. 


\begin{tabular}{|c|c|c|c|c|c|}
\hline & 1905 & 1915 & $\begin{array}{l}\text { Increase } \\
\text { (per cent) }\end{array}$ & $\begin{array}{c}\text { Decrease } \\
\text { (per cent) }\end{array}$ & 1916 \\
\hline Georgia......... & 277 & 406 & 47 & & 414 \\
\hline Florida......... & 87 & 133 & 53 & & 136 \\
\hline$\ldots \ldots \ldots$ & 791 & 895 & 13 & & 922 \\
\hline Indiana . . . . . . . . & 548 & 646 & 18 & & 672 \\
\hline Illinois . . . . . . . & 995 & 1,007 & 1 & & 1,047 \\
\hline Michigan........ & 556 & 814 & 46 & & 847 \\
\hline Wisconsin . . . . . . & 1,096 & 1,626 & 48 & & 1,675 \\
\hline Minnesota........ & 837 & 1,186 & 42 & & 1,210 \\
\hline Iowa............ & 1,336 & 1,377 & 3 & & 1,391 \\
\hline Missouri . & 570 & 797 & 40 & & 837 \\
\hline North Dakota ..... & 194 & 339 & 75 & & 373 \\
\hline South Dakota...... & 402 & 453 & 13 & & 485 \\
\hline Nebraska.......... & 669 & 625 & & 7 & 650 \\
\hline Kansas. . . . . . . . . & 671 & 726 & 8 & & 762 \\
\hline Kentucky . . . . . . . & 287 & 390 & 39 & & 406 \\
\hline Tennessee. . . . . . . & 283 & 355 & 25 & & 366 \\
\hline Alabama......... & 230 & 384 & 67 & & 396 \\
\hline Mississippi ........ & 272 & 434 & 60 & & 447 \\
\hline Louisiana......... & 166 & 268 & 61 & & 271 \\
\hline Texas............. & 838 & 1,086 & 30 & & 1,119 \\
\hline Oklahoma........ & 187 & 494 & 164 & & 519 \\
\hline Arkansas.......... & 281 & 387 & 38 & & 402 \\
\hline Montana......... & 55 & 114 & 107 & & 129 \\
\hline Wyoming ........ & 20 & 46 & 130 & & 50 \\
\hline Colorado.......... & 121 & 205 & 70 & & 219 \\
\hline New Mexico....... & 20 & 68 & 240 & & 76 \\
\hline Arizona.......... & 19 & 44 & 132 & & 53 \\
\hline Utah....... & 73 & 92 & 26 & & 96 \\
\hline Nevada...... & 17 & 24 & 41 & & 25 \\
\hline Idaho. . & 60 & 120 & 100 & & 126 \\
\hline Washington....... & 159 & 253 & 59 & & 263 \\
\hline Oregon......... & 139 & 210 & 51 & & 216 \\
\hline California... & 355 & 541 & 52 & & 568 \\
\hline All States...... & 17,572 & 21,262 & 20.9 & & 21,988 \\
\hline
\end{tabular}




\section{APPENDIX B}

\section{GRADING SYSTEMS}

\section{COMMISSION ON MILK STANDARDS}

of the New York Milk Committee*

Proper milk standards are essential to efficient milk control by public health authorities. In the first place health authorities must ascertain that the chemical composition corresponds with established definitions of milk as food, but their more important duty is to prevent the transmission of disease. This means the prevention of the transmission by milk of infant diarrhea, typhoid fever, tuberculosis, septic throat infections, scarlet fever, diphtheria, and other infectious diseases. In the interests of milk consumers public health authorities must take positive action to prevent the transmission of any of these diseases, in addition to their duty of preserving the food value of milk.

The milk producer is interested in proper standards for milk, and should support a movement to secure proper standards, for the reason that these contribute to the well-being and dignity of the milk industry itself. Proper standards, rightly enforced, distinguish between the good-milk producer

* Extracts from 3d Report (Public Health Reports, Feb. 16, 1917). This commission is national in personnel and scope and is loosely known as the "National Commission on Milk Standards." The reader is earnestly referred to the reports of the Commission for fuller information on milk control, production, handling, and distribution than can be given in these limited excerpts. These reports are the most important item in milk control literature. They may be obtained from the N. Y. Milk Committee, 105 East 22d St., New York City. 
and the bad-milk producer. This inevitably will lead to the improvement of dairy farming, and eventually to an increase in the financial prosperity of the milk producer himself through better prices for better milk. It will enable the producer to get properly paid for the quality of milk he produces, and thus put that industry for the first time upon a dependable basis.

The milk dealer finds the classification of milk resulting from milk standards to his financial advantage for the reason that it identifies clearly first-class milk and distinguishes it from second-class milk. Such a distinction gives to the seller of first-class milk the commercial rewards which such milk deserves, and the official label creates a market for first-class milk which the dealer alone is unable to create.

For milk consumers the setting of definite standards accompanied by labeling with official control of the labels makes it possible to know the character of the milk which is purchased, and to distinguish good milk from bad milk. The establishment of standards for quality, and of labels on retail packages indicating the quality, compels the industry not only to purchase milk on a quality basis, but also to sell milk on a quality basis. The selling of milk strictly on a quality basis, which includes not only chemical composition but sanitary character, makes it possible for consumers by an inspection of the label intelligently to select milk which in quality and price is most suitable for their needs.

\section{ADMINISTRATIVE EQUIPMENT}

Standards are useless unless properly guarded and enforced. The chief objection that has been raised to a grading system for milk is the difficulty of insuring that milk labeled as of a certain grade is actually of that grade when sold to the consumer.

The prime requisite for efficient milk control is that health 
departments shall be adequately equipped with men, money, and laboratory facilities. The commission is of the opinion that satisfactory results cannot be expected from laws when there is not sufficient appropriation, and when there is no machinery for their enforcement. A survey of the money appropriated for milk control shows that in the majority of municipalities this is entirely insufficient for public needs.

The key to the solution of the problem of the proper use of grade labels is the laboratory. The establishment and operation of an efficient milk testing laboratory is commonly supposed to be an item of great expense. This, however, the commission is convinced, is a mistake, since there are numerous laboratories scattered all over the land not only private, but public, which are inexpensive and operated at low cost. By efficiency methods a large number of tests can be made at a very low cost. Even small communities can afford to maintain and operate such laboratories. Where for any reason it is not possible to do this, it has proven to be practicable for one community to enter into laboratory arrangements with another, and even several can combine in the use of a common laboratory.

\section{GRADING OF MILK}

There is no escape from the conclusion that milk on the market must be graded just as other commodities such as wheat, grain, beef, etc., are graded. The milk merchant must judge not only of the food value but also of the sanitary characteristics of the commodity in which he deals. . . . The high-grade product, fresh and cold, will cost more to buy from the producer, and should sell for more to the consumer than does the low-grade product. The commission's most important work has been the attempt to separate milk into grades and classes. The commission has endeavored to make its grading system as simple as possible, and at the same time 
to distinguish between milks which are essentially different in their sanitary and other character. The commission is convinced that the experience of the last three years has fully demonstrated the value of the grading system in the communities in which it has already been applied, both from a public health and an economic standpoint. The commission believes that the grading of milk offers a satisfactory solution for most of the sanitary and economic problems which have hitherto prevented efficient milk control, and that it is feasible for small communities as well as large communities to adopt a grading system and to secure its benefits. . . .

The Commission believes that all milk should be classified by dividing it into three grades, which shall be designated by the letters of the alphabet. It is the sense of the Commission that the essential part is the lettering and that all other words on the label are explanatory. In addition to the letters of the alphabet used on caps or labels, the use of other terms may be permitted so long as such terms are not the cause of deception. Caps and labels shall state whether milk is raw or pasteurized. The letter designating the grade to which the milk belongs shall be conspicuously displayed on the caps of bottles or the labels of cans.

The requirements for the three grades shall be as follows:

\section{Grade A}

Raw Milk.-Milk of this class shall come from cows free from disease as determined by tuberculin tests and physical examinations by a qualified veterinarian, and shall be produced and handled by employees free from disease as determined by medical inspection of a qualified physician, under sanitary conditions, such that the bacteria count shall not exceed 10,000 per cubic centimeter at the time of delivery to the consumer. It is recommended that dairies from which 
this supply is obtained shall score at least 80 on the United States Bureau of Animal Industry score card.*

Pasteurized Milk.--Milk of this class shall come from cows free from disease as determined by physical examinations by a qualified veterinarian, and shall be produced and handled under sanitary conditions, such that the bacteria count at no time exceeds 200,000 per cubic centimeter. All milk of this class shall be pasteurized under official supervision, and the bacteria count shall not exceed 10,000 per cubic centimeter at the time of delivery to the consumer. It is recommended that dairies from which this supply is obtained should score at least 65 on the United States Bureau of Animal Industry score card.

\section{Grade B}

Milk of this class shall come from cows free from disease as determined by physical examinations, of which one each year shall be by a qualified veterinarian, and shall be produced and handled under sanitary conditions, such that the bacteria count at no time exceeds $1,000,000$ per cubic centimeter. All milk of this class shall be pasteurized under official supervision, and the bacteria count shall not exceed 50,000 per cubic centimeter when delivered to the consumer.

It is recommended that dairies producing Grade B milk should be scored, and that the health departments or the controlling departments, whatever they may be, strive to bring these scores up as rapidly as possible.

\section{Grade C}

Milk of this class shall come from cows free from disease, as determined by physical examinations, and shall include

* The fallacy of the present dairy-score requirements for grades has been discussed in the present volume (pp. 73, 74,75). It is found in all the classifications given in this appendix.-J. S. M. 
all milk that is produced under conditions such that the bacteria count is in excess of $1,000,000$ per cubic centimeter.

All milk of this class shall be pasteurized, or heated to a higher temperature, and shall contain less than 50,000 bacteria per cubic centimeter when delivered to the consumer.

Whenever any large city or community finds it necessary, on account of the length of haul or other peculiar conditions, to allow the sale of Grade C milk, its sale shall be surrounded by safeguards such as to insure the restriction of its use to cooking and manufacturing purposes.

[Recommendation relative to bacteriological tests for grades:- ]

That the grade into which a milk falls shall be determined bacteriologically by at least five consecutive bacteria counts, taken over a period of not less than one week nor more than one month, and at least four out of five of these counts (80 per cent) must fall below the limit or standard, set for the grade for which classification is desired.

[The Commission's definition of pasteurization has been quoted on a previous page (p. 103).]

\section{CREAM}

Cream should be classified in the same grades as milk in accordance with the requirements for the grades of milk, excepting the bacterial standards, which in 18 per cent cream shall not exceed five times the bacterial standard allowed in the same grade of milk.

Cream containing other percentages of fat shall be allowed a modification of this required bacterial standard in proportion to the change in fat. 


\section{Grades for Smail Cities and Towns}

This Commission recognizes that, because of climate, size of the community, nearness to the sources of supply, ease of transportation, and progress already made in improving the general milk supply and in educating the dairymen and the public, different communities are in position to secure varying degrees of excellence in their standards for the grades of milk. This Commission, therefore, urges that its standards for Grade A, B, and C milk be regarded as minimum standards, and that any community may adopt higher requirements for its grades if its conditions make this feasible and desirable.

As a guide to health officers in the establishment of grades best adapted to their local communities, the following general broad principles are offered:-

(1) A careful preliminary survey of the milk situation should be made before the requirements of the several grades are adopted.

(2) No matter how excellent the general milk supply of a community, it is not all of a single standard of excellence; hence there are actually different grades of milk in every community, and the recognition of such grades is always advantageous.

(3) Grades in any community should always be such as to separate into two, or at most three, classes the milk supply of that special community. Where little or nothing has been done towards improving the general milk supply, it may be desirable to adopt temporary grades (but not below the minimum requirements suggested by this Commission), with a time limit as to when more rigid requirements for the grades will be enforced.

(4) Grades as adopted in any community should be such as not, under any circumstances, to sanction the sale of milk below the minimum standards which it is feasible for that community to require. 
(5) Whatever departures are made by any community from the exact definition of grades as recommended by this Commission, several fundamental principles are recognized by the Commission as of universal application, and from these there should be no variation. These fundamental principles are:-

(a) Grade A milk in a general way, is milk which complies with requirements of such character and degree that, for all practical purposes, no real advantage would be gained by further and higher requirements. The standards for this grade should, therefore, be placed high enough to attain this end, but not so high as to limit too greatly the supply or, through unduly raising the price to the consumer, to limit too greatly the demand.

(b) Grade B milk is all the remaining milk of the community which is suitable for drinking purposes, after pasteurization, but which does not comply with the high requirements for Grade A milk.

(c) Grade $\mathrm{C}$ milk is milk which falls below the minimum requirements for milk suitable for drinking purposes, even after pasteurization. Its use must be confined to cooking and manufacturing purposes. Recognition of this grade of milk is not recommended by this Commission except in communities in which such recognition is an economic necessity.

(6) The fundamental objects in grading milk are:-

(a) To aid in making safe for human consumption all milk which can legally be sold for drinking purposes;

(b) To distinguish between classes of milk which, while all are safe, are of different degrees of excellence in respect to cleanliness and care in handling.

Each community should, therefore, endeavor to grade its milk supply so as best to attain these objects without departure from the broad general principles above laid down. 


\section{NEW YORK CITY*}

The basis of this system is the division of supplies into: (1) milk for infants, (2) milk for adults, and (3) milk for cooking and manufacturing purposes only,-requiring three corresponding grades.

\section{Grade A}

Raw Milk.-Cows tuberculin-tested annually and in good physical condition. Bacterial limit, 60,000 per c.c. Dairies to score 75 on the Department's score card. $\dagger$

Pasteurized Milk.-No tuberculin test required, but cows must be healthy-annual physical examination. Bacterial limits: 200,000 before, 30,000 after, pasteurization. Required dairy score, 68 .

\section{Grade B}

Pasteurized Milk.-No tuberculin test required, but cows must be healthy-annual physical examination. Bacterial limits-before pasteurization: 1,500,000 if pasteurized in city, 300,000 if pasteurized outside city; after pasteurization, 100,000. Required dairy score, 55 .

\section{Grade C}

(For cooking and manufacturing purposes only)

Pasteurized Milk.-No tuberculin test required, but cows must be healthy - annual physical examination. Bacterial

* Abstracted from the Rules and Regulations relating to the Sale of Milk and Cream of the Department of Health of New York City, to which the reader is referred for further particulars. (See also: Brown, Lucius P., "The experience of New York City in grading market milk," American Journal of Public Health, July, 1916, p. 671.) This classification closely approximates that quoted above.

$\dagger$ There are also score requirements for equipment and methods separately considered, in addition to the total score required under each grade. See footnote, p. 193 of the present volume, regarding score requirements in general. 
limit after pasteurization, 300,000. Required dairy score, 40. (Grade $\mathrm{C}$ milk is milk not conforming to the requirements of any of the above classes and which has been pasteurized properly or boiled for at least two minutes.

\section{Pasteurization}

Official definition: subjection to a temperature averaging $145^{\circ} \mathrm{F}$. for not less than 30 minutes.

\section{CLASSIFICATION OF CREAM}

The same classification applies to cream, but the bacterial limits (after pasteurization, except in the first case) are as follows: Grade A (raw), 300,000; Grade A (pasteurized), 150,000; Grade B (pasteurized), 500,000; Grade C (pasteurized), 1,500,000.

The following commentary from the Secretary of the New York Milk Committee, Mr. Paul E. Taylor, regarding the effects of grading in New York City, is of interest (italics inserted) :-

Notwithstanding the Department's activities in enforcing the present standards, the good dealers and the clean producer agree that the new system of grading milk on its sanitary character for the first time gives public recognition to those who produce and handle a clean article.

That the dealer recognizes the commercial value of Grade "A" pasteurized milk is shown by the fact that one large company doing business in several cities, in October, 1914, was selling an average daily total of 22,000 quarts of Grade "A" pasteurized nilk, produced under conditions in accordance with requirements of the New York City Board of Health regulations, and the producers of which received a bonus because of the extra care exercised. Wherever this milk was sold it bore the label "Grade A Pasteurized" and brought 1 to 3 cents a quart more than the ordinary bottled milk. In October, 1915, the average daily sale of this milk by the company. was 500,000 quarts. The managers of the company say this method 
of giving recognition to clean milk is the best thing that ever happened to the milk industry.

... The success of the system depends upon maintaining the integrity of the label.

About 99 per cent of New York City's milk supply is pasteurized.*

\section{NEW YORK STATE $\dagger$}

\section{Grade A $\ddagger$}

Raw Milk.-Annual tuberculin test. Bacterial limit: 60,000. Dairies must score 25 per cent for equipment, 50 for methods, on the score card officially prescribed.

Pasteurized Milk.-Annual physical examination of cows. Bacterial limits: 200,000 before pasteurization; 30,000 after. Required dairy scores: 25 per cent for equipment, 43 for methods.

\section{Grade B}

Raw Milk.-Annual physical examination of cows. Bacterial limit: 200,000. Required dairy scores: 23 per cent for equipment, 37 for methods.

Pasteurized Miik.-Annual physical examination of cows. Bacterial limits: 1,500,000 before pasteurization; 100,000 after. Required dairy scores: 20 per cent for equipment, 35 for methods.

* Personal communication, Dec. 6, 1915.

$\dagger$ Abstracted from the Sanitary Code established by the Public Health Council of the State of New York, as amended.to and including Oct. 5,1915 . The above are only the salient requirements; the reader is referred to Ch. III of the Code and its revisions for details. The classification is prescribed to apply except as otherwise stated, throughout the State with the exception of New York City. Some account of its working is given by Linsly R. Williams, Deputy Commissioner of Health, "The grading of milk in small communities," Am. Jour. Public Health, Oct., 1916.

$\ddagger$ Certified milk constitutes a special class. 


\section{Grade C}

Raw Milk.-Required dairy score, 40 per cent. Pasteurized Milk.-Same.

\section{CREAM}

Cream is classified in the same grades, but the bacterial limits are higher.

The bacterial count herein required shall be made only at county or municipal laboratories or such other laboratories as may be approved by the state commissioner of health.

In those municipalities where a bacterial count of the milk is, in the opinion of the local health authorities, impracticable, they may in their discretion grade milk and cream according to the score of the dairies producing it, as prescribed in this regulation, but no such milk shall be designated "certified," "Grade A raw," or "Grade A pasteurized." *

This regulation shall not be construed to rescind or modify any existing local regulation or ordinance controlling the grading of milk or cream established prior to the first day of September, 1914.

The health authorities of any municipality may in their discretion increase the stringency of these regulations or add to them in any way not inconsistent with the provisions thereof.

It will be noted that the above classification is more lenient than those preceding. In view of this fact and the circumstance that this is the first state classification, it may be presumed that these standards may later be raised.

\section{RICHMOND, VA.}

Richmond, Va., a city of some 150,000, the health department of which has long been active in clean milk work, has

Such authorizing of grades according to dairy scores alone is a very. serious defect of this system. See footnote, p. 193.-J. S. M. 
recently established a simpler classification than any of the above, as follows:-

\section{Grade A}

Raw Milk.-Cows free from disease and tuberculin-tested. Employees free from disease. Bacterial limit: 25,000 (November to March, inclusive); 50,000 (April to October). Required dairy score (U. S. Official): 80 points, of which at least 45 for methods.

Pasteurized Milk.-Same, with bacterial limit after pasteurization of 5,000 .

\section{Grade B}

Pasteurized Milk. Cows free from disease-at least one official physical examination per year. Bacterial limits: 250,000 before pasteurization, 25,000 after. Required dairy score, 70 (65 permitted, temporarily).

Cream is classified in the same manner, but with higher bacterial standards.

\section{ORANGE, N. J.}

The following plan was adopted in 1915 under the cooperative organization for milk control in Orange, N. J., and neighboring municipalities (see page 167):-

\section{Grade A}

Raw Milk.-Cows in good physical condition and tuberculin-tested. Bacterial limit: 50,000 (November to April, inclusive); 100,000 (May to October).

Pasteurized Milk.-Cows physically examined. Bacterial limits: 200,000 before pasteurization and 30,000 after (summer months); 100,000 before and 10.000 after (winter months). 


\section{Grade B}

Raw Milk.-Cows in good physical condition and tuberculin-tested. Bacterial limit: 100,000 (winter months); 300,000 (summer months).

Pasteurized Milk.-Cows physically examined. Bacterial limits: 750,000 before pasteurization and 75,000 after (summer months); 500,000 before and 40,000 after (winter months).

Score requirements (U. S. Official card), respectively: 75, 70, 65, 60 .

Certified milk is made an extra class.

\section{EXTENSION OF THE GRADING IDEA}

Other communities than the foregoing have also adopted or are considering grading systems. The author has not sought to make a complete collection of data on the subject. The New York Milk Committee has sought to bring the recommendations of the Commission on Milk Standards before many communities, and reports that the grading idea is making encouraging progress as shown in recent milk regulations. 


\section{APPENDIX C}

\section{THE NORTH SYSTEM *}

Origin and Development.-The plan of milk production and milk handling outlined below was first proposed by Dr. Charles E. North in September, 1903. In old barns on the premises of his certified dairy farm in New Jersey and in old barns in the immediate neighborhood, he was successful during the years 1903 and 1904 in producing milk containing exceedingly small numbers of bacteria by the practice of a system which he had devised. In 1908 Dr. North became a member of the New York Milk Committee and pointed out to this organization the advantages of this method of milk production. This committee raised the capital for the organization of a small milk company, which had for its object the carrying out, experimentally, of this milk system on a large scale. Because of its experimental character the milk company took the title of The New York Dairy Demonstration Company.

For two years past [i. e., since 1910] the company has operated a milk shipping station at Homer, N. Y., and has produced milk in accordance with the system proposed by Dr. North and has conducted all its sanitary operations under his personal supervision. $\dagger$ Beginning with three dairy

* Reprinted, by permission, from a description issued in 1912, by Dr. Charles E. North, Director, North Public Health Bureau, 30 Church St., New York City, with additional notes from information personally communicated. This system is referred to at p. 78 of the present volume.

$\dagger$ "Since the rather perilous undertaking at Homer," writes Dr. North, "the soundness of the principles developed there has been em203 
farms and about 600 quarts of milk two years ago, the company now receives milk from about 70 dairy farms and its volume of business has grown to more than 10,000 quarts daily. It has found its largest market in the infant milk depots operated by the New York Milk Committee and under the auspices of the New York City Department of Health. During the summer of the present year there have been 55 milk depots in Manhattan and Brooklyn, feeding during the hot months 14,000 babies per day. The company has supplied all of the milk to these stores and this supply has been a large factor in the reduction of infant mortality, which this summer has been the lowest in the history of the city.

\section{Outline of North's Milk System}

1. Object.-The objects of this system are the production of clean milk at low cost; to secure clean milk from the present milk producers and under the auspices of present milk dealers with the least possible disturbance of commercial conditions; to reduce to a minimum the dairy equipment and the sanitary measures used on dairy farms, retaining only those things positively essential for clean milk produc-

phatically demonstrated, not only there, but in numerous other places." There are now (1916) established under supervision of Dr. North a station in Maryland, one in New Jersey, three in Pennsylvania, two more in New York State, and one in Vermont. There are over one hundred farms supplying milk to the Homer station at the present time, and the total number of quarts is over 20,000 quarts daily. The number of milk depots in Manhattan and Brooklyn is now over sixty, and the number of babies feeding from these is nearly 25,000 daily. At Oxford, Pa., the station ships milk produced by 135 dairymen. "This place," says Dr. North, "is more remarkable than Homer, because the majority of the men do not have ice, and the character of their barns and dairy equipment is very much inferior to that at Homer, yet, in spite of these drawbacks, the majority of them are producing milk with a very low bacterial count." 
tion; the securing of such clean milk as is to be sold in a raw condition; the cleaning up of all milk which is to be pasteurized, in the belief that all milk used for drinking purposes should be clean in the first instance, whether pasteurized or not.

2. Centralization.-The backbone of the system is the principle of centralization. While modern business has brought about great organizations in the selling department of the milk industry, the producing end of the line has been left largely to shift for itself. Milk producers are permitted to produce milk under their own auspices and by such methods as their ignorance and carelessness may dictate. Many things done on dairy farms can be done much better in a central station. Among these are washing and sterilizing of milk cans and milking pails, bottling of milk and laboratory testing of milk. Sixty per cent of the dairy farms have polluted well water and as large a percentage have inefficient methods of washing and sterilizing utensils and of cooling milk.

3. Organization.-The advocates of certified milk have not considered fully business organization. Certified dairies make no use whatever of the principle of centralization. Each certified dairy conducts its business in a most extravagant and inefficient manner. Each certified dairy farm is fully equipped to conduct its business as a separate unit, regardless of the volume of business.

Instead of each farm being a separate unit with a small volume of business, North's Milk System makes them each a part of a large organization with a large volume of business. ... [See lower diagram of Fig. 4, chapter II, as a substitute for the diagram which we omit here.] The dairy farms are each members of a group patronizing the central sterilizing station. At the central plant milk is received and shipped. This station, as a matter of fact, is a large dairy house and performs all of the functions of a dairy house for 
each of the different farmers. In short, the dairy farmers take care of their barns and feed and milk their cows, while the central station takes care of the milk which the farmers bring to it. From the central station the milk is shipped to the city in the usual way.

4. Plant and Equipment.-The plant consists of a building such as is commonly used for creamery purposes or for a milk shipping station. It must be large enough to accommodate the volume of milk which it is expected to collect from the territory and must be constructed in accordance with the well-recognized principles of milk sanitation. It must have water-tight floors, abundant lighting and ventilation, proper drainage and water supply, and must be constructed so that it can be easily cleaned. It should include separate rooms for receiving milk, for washing pails and cans, for cooling, bottling and pasteurizing milk, for bottle washing, for power plant, for ice, and accommodations for employees, office, laboratory and storage. The equipment should include tanks for receiving milk, cooling, bottling and pasteurizing equipment, bottle washing machinery, power plant, refrigerating apparatus, and equipment for washing milking pails and milk cans, a complete laboratory equipment for examining milk for bacteria and butter fat, and the proper type of covered milking pails and milk cans, milk bottles, etc.

So far as the dairy farms are concerned but little additional expense is necessary. Of the seventy farms at Homer, N. Y., which have patronized the station of the New York Dairy Demonstration Company, the only expense generally undertaken has been for tanks of wood, or of cement, or of galvanized iron, to hold ice-water in which the 40-quart cans of night's milk have been stood for cooling purposes. Aside from this, more frequent whitewashing of barns and additional care in cleaning cow stables have been the chief external evidences of extra sanitary precautions. 
5. Sanitary Measures.-The following is a list of sanitary measures which are insisted upon:

1. At Dairy Farms:-

(a) All milking must be done in covered milking pails provided by the central station. These milking pails must have small mouths with tin covers and must be kept clean during transportation from the central station to the farm.

(b) Milking pails and milk cans must not be washed or sterilized on the dairy farm.

(c) No strainers must be used. No other milk utensils must be used, excepting those provided by the central station.

(d) All milk must be cooled in 40 qt. cans by placing the cans in ice water, excepting where milk is delivered to the central station within three hours after milking.

2. At Central Plant:

(a) All farmers' milking pails are washed, sterilized and dried.

(b) All milk cans are washed, sterilized and dried.

(c) All milk is cooled and bottled.

(d) Bottle washing and sterilizing.

(e) Refrigerating and shipping.

6. Sanitary Control.-It is one thing to recommend sanitary measures; such recommendations have been made for years by public and private authorities interested in milk reform. It is quite another thing to have sanitary measures adopted and carried out. If there is any virtue in the milk system herein described, it lies not so much in the sanitary measures themselves, which are already well known, but it lies in the means taken for securing their adoption. These may be summed up under the term of Sanitary Control, and are as follows:-

(a) Medical inspection of dairy employees by a resident physician. The local country doctor finds it con- 
venient in his frequent trips to keep posted as to the health of the dairy employees and to make regular reports to the central station.

(b) Veterinary inspection of the dairy cattle by the local resident veterinarian with regular reports of their physical condition.

(c) Sanitary inspection of dairy farms by a resident sanitary expert, who is the superintendent of the central station. This superintendent must have bacteriological training sufficient to enable him to carry out laboratory tests for bacteria, or to supervise the same. He must also supervise all sanitary processes in central plant and on dairy farms. His influence must be the chief factor in maintaining sanitary conditions and in interpreting laboratory results, so that milk producers will have confidence in the same.

(d) Regular laboratory tests for bacteria of each farmers' milk made in the laboratory of the central station. This laboratory needs only simple and inexpensive equipment and the bacterial work consists of making bacteria counts by the plate method. Samples are taken of farmer's milk as this milk is delivered each day to the station.

(e) Chemical tests for butter fat and total solids when necessary from samples taken of milk delivered by the farmers. These tests also to be made in the station laboratory.

(f) A bulletin board on which are posted the results of all laboratory tests, so that they may be seen by the farmers patronizing the station.

(g) Payment to dairy farmers for milk based on its sanitary character as shown by bacterial tests and on its richness as shown by chemical analyses. This method of payment is the secret of the Sanitary Control. By exercising extreme care and thereby reducing the bac- 
terial count of his milk, the dairy farmer can earn more money than he does if he is careless and delivers milk containing large numbers of bacteria. The adjustment of the price to the bacterial count on the one hand, and to the percentage of butter fat on the other hand, gives a strong stimulation to the dairy farmer to produce milk which is both clean and rich. Only small premiums are necessary to give great stimulation in these two respects.

(h) Tuberculin testing of dairy cattle is an entirely separate problem. It has become recognized that raw milk to be safe for drinking purposes must be obtained from cattle which are free from tuberculosis as determined by the tuberculin test. The securing of such milk involves principles which are the same as those above outlined, namely, that the producer must be paid for the cost. More than half of the milk delivered to the central station at Homer, is obtained from dairies having herds which have passed the tuberculin test. These tests have been made as the direct result of a special premium paid to the dairy farmers for milk from tuberculin tested cows. This premium has been paid in addition to the other premiums mentioned.

\section{Results}

The use of this system on a large scale has given all of the results anticipated from the preliminary experimental work carried out by Dr. North in old dairy barns in New Jersey. The daily bacterial tests of milk carried out in the laboratory of the central station of the New York Dairy Demonstration Company at Homer, N. Y., are now on file, and show that, while there have been some irregularities, yet in general the milk delivered to this station is clean, and has a bacterial count which is far lower than can be obtained by ordinary 
methods. This has been confirmed by the tests made in other laboratories in places to which this milk has been shipped.

As an illustration of the character of the milk delivered to the station by dairy farmers, one of the daily laboratory record sheets is given below:

\section{CREAMERIES OF THE}

NEW YORK DAIRY DEMONSTRATION CO.

ANALYSIS OF MILK AND CREAM

Date, July 26/12.

\begin{tabular}{|c|c|c|c|c|c|}
\hline \multicolumn{6}{|c|}{ TUBERCULIN-TESTED DAIRIES } \\
\hline \multirow{2}{*}{$\begin{array}{c}\text { Dairy } \\
\text { no. }\end{array}$} & \multirow{2}{*}{ Name of owner } & \multirow{2}{*}{$\begin{array}{c}\text { Butter- } \\
\quad \text { fat }\end{array}$} & \multirow{2}{*}{ Temp. } & \multicolumn{2}{|c|}{ Bacteria per c.c. } \\
\hline & & & & Night & Morning \\
\hline 1 & T. Bell. & 3.5 & 52 & 500 & \\
\hline 2 & W. Bell . . . . . . . & & & & \\
\hline 3 & C. C. Bennett... & & 56 & 500 & 400 \\
\hline 4 & F. L. Burnham ........ & 3.4 & 56 & 2,500 & 2,000 \\
\hline 5 & R. Butler............ & 3.2 & 46 & 500 & 1,500 \\
\hline 6 & C. H. Button........... & 3.7 & 50 & 10,000 & 500 \\
\hline 7 & I. C. Button........... & 3.3 & 46 & 4,000 & 2,000 \\
\hline 8 & 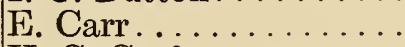 & 3.4 & 54 & 9,000 & 15,000 \\
\hline 9 & H. C. Crofoot . . . . . . & 3.5 & 52 & 15,000 & 1,000 \\
\hline 10 & Crofoot \& Cummings... & & & & \\
\hline 11 & Ed. Foster . . . . . . . . . . & & 54 & 1,500 & 1,000 \\
\hline 12 & Fox Bros . . . . . . . . & & & & \\
\hline 13 & S. Gillett. & 3.5 & 52 & 10,000 & 1,000 \\
\hline 14 & J. R. Hathway.... & 3.2 & 50 & 1,000 & 1,000 \\
\hline 15 & N. D. Hitchcock. . . . . . & & 48 & 1,000 & 1,000 \\
\hline 16 & H. R. Holl . . . . . . . . & & 52 & 1,000 & 5,000 \\
\hline 17 & H. H. Jones . . . . . . . . . & 3.6 & 50 & 1,000 & 5,000 \\
\hline 18 & R. Jones. & 3.8 & 54 & 2,000 & 3,000 \\
\hline 19 & L. E. Klock . . . . . . . . & & 50 & $\overrightarrow{1}, 000$ & 2,500 \\
\hline 20 & W. H. Miller ........... & & 48 & 1,000 & 1,500 \\
\hline 21 & Perry Bros. . . . . . . . . . & 4.4 & 42 & 3,000 & 1,500 \\
\hline 22 & C. F. Pratt. . . . . . . & 3.6 & 48 & 2,000 & 1,500 \\
\hline 23 & M. E. Pratt. . . . . . . & 3.6 & 48 & 1,500 & 2,500 \\
\hline 24 & F. Rice. . . . . . . . & 3.5 & 52 & 1,000 & 2,500 \\
\hline 25 & Crofoot \& Rogers...... & & & & \\
\hline 26 & D. Sellen . . . . . . . . . & & 54 & 5,000 & 1,000 \\
\hline 27 & C. W. Wilkins . . . . . . . & 3.8 & 46 & 1,500 & 2,500 \\
\hline 28 & F. M. Williams . . . . . . & 3.8 & 50 & 1,500 & 1,500 \\
\hline
\end{tabular}


NON-TUBERCULIN-TESTED DAIRIES

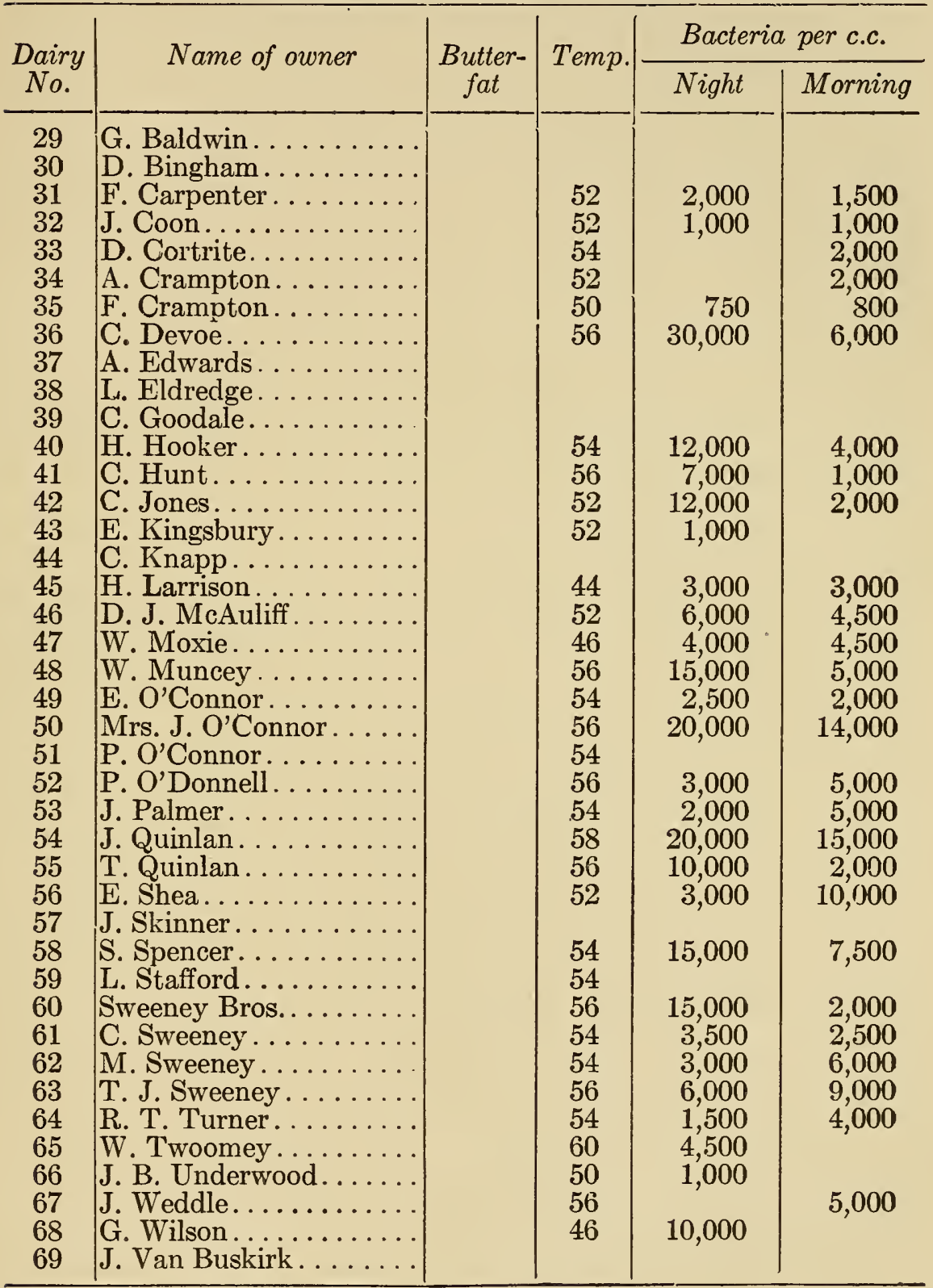

The dairy farms on which this milk is produced, while some of them are of superior character, are in general the 
type of dairy farms seen throughout the great producing sections of the milk industry. ${ }^{*}$ The majority of the dairy barns are simple and inexpensive in construction, and have none of the elaborate and expensive features of the certified dairies. The cleanliness of the milk produced by these dairies was well illustrated in the recent milk competition held at the New York State Fair, at Syracuse, in September, 1912. In this contest two of the Homer farmers obtained scores for their milk superior to the scores of fifteen certified dairies entered, and were only beaten by the score of one certified competitor. Of the thirty-nine entries in the competition, seven were milks from the Homer station, and these took five places out of the first fourteen entered.

\section{Relation to Milk Industry}

There are several branches of the milk industry which have already shown an interest in the adoption of this system of milk production and handling. Certain modifications are necessary to adapt the plan to the peculiar character which the industry may have in different parts of the country. Enough work has been done to date, however, to demonstrate that in this way clean milk can be produced in large quanti-

* "The fact that the shipping stations and dairy farms furnish no external evidence to the casual inspector of any differences from other stations and farms shows that external appearances give a very small clue to the real character of the product. The testing of the product itself shows immediately to the investigator a most startling difference between the milk produced at these stations and the milk produced at ordinary shipping stations. Furthermore, the most vital factor at work in these dairy districts is invisible, because this factor is summarized in the word 'influence.' The influence of the bacterial test and of the system of payment on the mind of the producer keeps him keyed up to a high pitch of watchfulness and care. When the producer sits down to milk, his mind is preoccupied by two thoughts: one, bacteria; and the other, dollars. It is this influence which achieves the remarkable results brought about at these stations." (Communication from Dr. North.) 
ties by our present milk producers at a comparatively low cost. The principle of centralization of effort through the establishment of a central station under the supervision of a resident Sanitary Superintendent, and the payment for milk based on sanitary quality and chemical quality as determined by laboratory tests, are principles which can be adopted in any locality and which will bring sure results. A large volume of business can be secured by one central station receiving milk from a number of dairy farms. This makes necessary only one power plant, one bottling equipment, one washing and sterilizing equipment, one good artesian well, and the salaries of one superintendent and one force of dairy employees to handle the milk from several scores of farms. The volume is such that the tax for Sanitary Control and handling on each quart of milk is small. This form of organization gives efficiency and economy and means clean milk at low cost.

\section{References}

The following is a list to date of papers by Dr. North concerning the above system, its development and related matters:-

"A method of milk production," New York Medical Record, Feb. $15,1908$.

"Sterilizing stations in dairy districts," Journal of the American Public Health Assn., Sept., 1911.

"The production of sanitary milk by our present milk producers," 59th Annual Report, Mass. State Board of Agriculture, 1912.

"The market value of cleanliness in milk production," address delivered at 36th Annual Convention of New York State Dairymen's Association, 1912.

"The dairyman versus the dairy," American Journal of Public Health, June, 1915.

"Bacterial testing versus dairy inspection," American Journal of Public Health, June, 1916.

"A survey of dairy score cards," American Journal of Public Health, Jan., 1917. 


\section{APPENDIX D}

\section{COSTS AND PRICES}

Various investigations have been made of economic costs at different stages of the milk industry from cow to consumer. No attempt will be made here to present any general abstract of these, much less to discuss all the details. Cost items, furthermore, vary decidedly at different times and in different regions. Hence the results quoted below are to be taken merely as illustrative. The figures of direct significance in any locality are those derived from local conditions, e. g., by investigating bodies and agricultural agencies.

\section{COST OF PRODUCTION}

While most of the controversy relative to prices has centered about the cost of production, this is the hardest of the various costs to draw from practical conditions. Accurate bookkeeping by dairy farmers is very rare. Figures presented by farmers operating under common conditions show discrepancies and variations which must produce a sense of caution with regard to all such figures. The majority of dairy farmers, particularly small farmers, do not know the profit or loss on their business of milk production as a whole, much less on the outputs of individual cows in their herds. Many such farmers are producing milk either at a loss or at little or no profit, are not taking measures to improve their conditions, and are unable to present convincing figures when the question of milk prices arises.

The Boston Chamber of Commerce, through its Committee 214 
on Agriculture, in coöperation with various agricultural agencies, conducted throughout New England, in 1914, a series of public milk hearings which were attended by about 2,500 farmers. * At these hearings the farmers were interrogated on the following points:

What it costs per year to keep a cow.

The average production per cow per year.

Value of the calf.

Value of manure.

Other problems incident to the production of milk.

Their views as to what ought to be done.

The number of producers [reports the committee] who kept a strictly accurate record of all the [necessary] items was naturally small. During the last five or ten years, however, more attention has been given to the question of the cost of keeping a cow, and the number of producers who have kept accurate records has been rapidly on the increase. As a matter of fact, it was shown that it has been only within the last seven to ten years that serious consideration has been given to an analysis of the items of cost in the keeping of a cow.

More accurate figures were furnished by the producers of Vermont than by the producers of any other part of New England. It was shown that Vermont was the largest dairy state in New England and supports 34 cow test associations.

The testimony given by the farmers in the various sections of New England naturally showed a wide range of opinion as to the value of calf and manure, and as to the amounts and prices charged for the individual items. The peculiar conditions in each locality proved to be a large determining factor.

Taken over New England generally, under varying conditions and with varying degrees of efficiency (varying ability) and varying accuracy as to items of cost, the following range of figures represents fairly the evidence obtained at the hearings. . . .

* This was part of a general investigation of milk and cream conditions in New England. See Appendix E. 


\section{Total $\operatorname{Cost} *$}

Producer Producer Producer

No. 1 No. 2 No. 3

1. Feed,-hay, grain, ensilage, pasture................ $\$ 49.40$

2. Labor................ 17.72

3. Overhead charges
a. Interest on money invested in cow ............ 3.00
b. Insurance on cow. . . . . . .
c. Taxes on cow ...........
d. Depreciation of cow . . . . 5.00
e. Barn rent............ 2.86
f. Bedding. ..............
2.00
g. Keep of bull.......... 2.86
h. Incidentals,- - light, medi- cine, veterinarian, heat- ing water in winter, salt, etc.................

* "The two fundamental figures entering into the cost of a quart of milk are the net cost of keeping a cow per year and the amount of. milk the cow produces in a year." "All of the figures can be obtained by accounting for the total amount of each one of the items for the entire herd, then dividing by the number of cows, to obtain the individual cost. The total production of each cow, however, should be kept separate, as should also her'butter-fat test." The manner of figuring certain cost items is explained in the report as follows:-

1. Feed.-Hay, clover, alfalfa, were figured at the market prices that could be received for the same in the barn on the farm; grain for what it costs plus delivery to the farm; pasture according to its value, taken in comparison with hay and grain; ensilage at its estimated value, $\$ 3$ to $\$ 4$ per ton.

2. Labor.-Labor was charged at the local market price for just the time it takes to care for the cows.

3d. Depreciation of Cow.-Depreciation was reckoned in two ways: (1) depreciation over a period of 3,5 or 8 years, as to deaths, injuries, 
Credits

$$
\begin{array}{lll}
\text { No. } 1 & \text { No. } 2 & \text { No. } 3
\end{array}
$$

Value of calf .............. $\$ 1.00 \quad \$ 11.00 \quad \$ 5.00$

$\begin{array}{llll}\text { Value of manure............... } 5.00 & 10.00 & 15.00\end{array}$

$$
\overline{\$ 6.00} \quad \overline{\$ 21.00} \quad \overline{\$ 20.00}
$$

Net COST to KeEP A COW . $\$ \$ 80.94 \quad \$ 71.91 \quad \$ 142.00$

(These figures show that it costs No. 3 almost twice No. 2 to keep a cow.)

Figures obtained on production varied from 3,500 to 15,000 lbs. per year.

In the above three instances, the amount of production per cow was as follows:

$$
\begin{array}{lll}
\text { No. } 1 & \text { No. } 2 & \text { No. } 3
\end{array}
$$
5,293 lbs.
$6,590 \mathrm{lbs}$.
$8,000 \mathrm{lbs}$.

The cost of $100 \mathrm{lbs}$. of milk to each was, therefore,-
$\$ 1.5291$
$\$ 1.0911$
$\$ 1.775$

Cost per quart,--
$\$ 0.0332$
$\$ 0.0237$
$\$ 0.0385$

It is, however, "clear from the inconsistencies in these figures," remarks the Committee, "that they furnish no real basis for determining the actual cost of production."

The several factors entering into the foregoing results were found to vary widely in the different sections of the producing territory according to the grade of stock kept, the methods of feeding, and the character of the soil. These factors are discussed in the report.

As to the lack of accurate knowledge of cost of production among farmers, the Committee has this to say:-

It appeared that the situation was further complicated by loss of udder quarters; (2) depreciation as to the highest selling value of the cow as compared to its final value for beef.

3d. Barn Rent.-Barn rent was charged on a basis of what it would cost to erect a stable to keep the number of cows the producer maintains. 
the fact that producers generally had no accurate knowledge of a number of important factors affecting the cost of production on their farms.

Wide Range in Production.-1. This was particularly true in regard to the number of pounds of milk per cow. While figures obtained by the committee ranged from $3,500 \mathrm{lbs}$. to $15,000 \mathrm{lbs}$. per year, it was clear that there are many cows in New England producing under 3,500 lbs. per year.

It is exceedingly doubtful if most of the cows in New England are producing much more than 3,500 to $4,000 \mathrm{lbs}$. per year.

Small Percentage of Pure Breds.-The evidence demonstrated that while in many towns there are from 5 to 25 producers who have pure bred bulls and some have pure bred cows, as a matter of fact the majority do not have either; and outside of the cow test associations a disappointingly small per cent weigh or measure, although there has been a great increase in weighing in the last three or four years.

High Percentage Without Records.-Probably $80 \%$ of the farmers have no accurate idea what their cows are producing each year in pounds of milk, to say nothing of their test in butter-fat.

[The rest refers to inaccurate charging of barn rent and incldentals.]

The lack of any standardized methods of production and of accurate knowledge of costs is due, says the Committee, partly to temporary, partly to permanent, causes. The evidence indicated the following as the principal factors in producing and continuing this condition:

Commercial Dairying a New Industry.-1. The selling of milk and cream and the commercial creamery and cheese factory are not old, established industries. Fifty years ago saw the first commercial cheese factory, and thirty-six years ago the first commercial creamery. General shippirg, to any great extent, of milk and cream by cars began less than forty years ago. Formerly, farmers sold from their farms, for their cash income, corn, oats, wheat, beef, sheep, wool, eggs and poultry, home made cheese and butter, wood and logs. 
2. One great factor in the situation is the varying amount that the milk check contributes to the total amount of money received from all products within the year. Producers are of two main classes.

Milk Production the Main Business.-a. Producers whose milk and cream check is $90 \%$ of their total income.

Milk Production as a Side Issue.-b. Producers whose milk and cream check is $10 \%$ to $60 \%$ of their total income; who are selling market-garden produce, eggs, poultry, onions, tobacco, apples, potatoes, pigs, hogs, young stock, cows, wood and logs.

The $(a)$ producer is generally more concerned about his dairy business than $(b)$ producer, who is making milk a side issue and does not pay much attention to breeding, feeding, amount of production as compared with $(a)$ producer, but $(b)$ producers are a big factor and produce in the aggregate much milk and cream for the market.

Advent of Foreigners. - 3. Many foreigners are taking up farms and producing milk, working the entire family on the farm. Few. of these figure labor costs, but their milk and cream come into direct competition with the producer who figures each item.

Causes of dissatisfaction among producers were brought out as follows:-

Producers' Solution.-Although the cost of production varies greatly and is not accurately known, producers are practically unanimous that they are not receiving enough for their milk. The producer's solution is more money for his milk, ranging from 4 cents to 6 cents a quart at his door.

Test and Price Suspected.-It also developed that the producers suspected certain dealers of not giving them an honest test for butterfat. In some localities it was claimed that dealers paid producers a higher price for their milk or gave them a bonus for hauling milk, so as to keep peace in the locality, and prevent producers from getting together.

Deduction for Sour or Frozen Milk.-The dealers in some instances charged the producers for shortage, sour milk and frozen cream, for which the producer claimed he was not to blame, having delivered his product to the dealer in good condition and full measure. 
Monopolistic Methods.-It was also brought out that, in certain instances, dealers entered creamery districts offering the producers higher prices until such time as the dealer could secure control of the local creamery, when the prices paid producers would be reduced to make up for the higher prices previously paid.

The above has been quoted in order to indicate some of the considerations involved in detailed investigation of the economics of milk production. There never was a time when economic pressure required so much as now that the farmer consider carefully the actual cost of milk production. For every dairy farmer there are two problems: to detect, by means of individual records, * the poorest cows in his herd and dispose of these; then, by means of accurate farm accounts, to determine the costs after the poorest milkers have been eliminated. These costs, as we have remarked, vary so much by time, locality, and individual farm conditions that general figures are impossible. The important figure is the local figure, but it is, as yet, rare to find dependable statements even among those producers who claim to keep systematic accounts. Hence it is that a number of agricultural experiment stations have undertaken to ascertain accurately the costs in their respective localities. These figures are most useful when they not only make possible a comparison between efficient and inefficient farm management but also distinguish between ideal and practical conditions. It must be borne in mind that the average farmer cannot humanly be expected to take up at once the methods of the scientific expert of the experiment station.

To quote here the diverse figures obtained in different investigations under various conditions would confuse rather than illuminate. The reader will be best enlightened by consulting the most recent results from the experiment station in his own State. One of the most thorough experiment

* Cow-test associations assist the individual dairyman in doing this, or he may make his own tests. 
station studies comes from New York.* This gives the cost of producing milk on 174 farms in one county and also figures taken from bulletins from certain other States in recent years. The figures are, for cost per quart: New Hampshire, 4.2 cents; Massachusetts, 5.2; Connecticut, 4.6; New Jersey, 4.2; Delaware County, New York, 5.1 (1912) and 4.4 (1913). The writer of this bulletin recommends that "without doubt the greatest need for this region is more efficient cows," but adds that in his opinion "the farmer does not receive enough for his milk."

\section{RELATIVE COSTS OF LINKS IN THE MILK CHAIN}

Figures indicate that when milk is marketed through a middleman the farmer receives, roughly, from one-third to one-half the retail price, the remainder going for transportation, processes, distribution, overhead, and middleman's profit.

Owing to wide variations it is impossible to give adequate estimates of the general costs of the different operations of the city milk industry. Some idea of these is given by the finding in a recent investigation in New England that the total cost of collection in the country, operation of country plant, railroad transportation, and operation of city plant was a little over or under 3c.; while the cost of distribution to the family trade was $2 \mathrm{c}$. to $5 \mathrm{c}$.; to retail stores, in cases of bottles, $1 \mathrm{c}$. to $2 \mathrm{c}$.; and to the wholesale trade, $1 / 2 \mathrm{c}$. to $1 \mathrm{c}$. "The greatest single item of cost is, therefore, delivery to the family trade, equaling the cost of collection, country

* Thompson, A. L., "Cost of producing milk on 174 farms in Delaware County, New York," Cornell University, Agric. Exper. Sta., N. Y. State College of Agric., Bull. 364, Oct., 1915. Studies have also been made in other counties of New York. For further data see bulletins of the Federal Department of Agriculture and of the various state departments of agriculture and agricultural experiment stations.

$\dagger$ Boston Chamber of Commerce, special report, 1915. 
plant, railroad transportation, and city plant expense." * We have elsewhere (pp. 139-40) discussed this important item and its possible reduction.

The cost of the important sanitary item of pasteurization has been determined for certain city milk plants as (average) .313c. per gallon of milk (range, .229-.436) and .634c. per gallon of cream (range, .378-.939). $\dagger$ The "holding" method, which sanitary efficiency requires, was found to be more economical in use of heat than the "flash" method. In Chicago the cost of pasteurizing milk was found to range from one-thirtieth of a cent per gallon for large plants to .85c. per gallon for one small plant. $\$$

(Some details and unit costs of milk plant operations are taken up in the circular letters to city milk dealers published by the Dairy Division, Bureau of Animal Industry, United States Department of Agriculture.)

\section{THE EXTRA COST OF PRODUCING CLEAN MILK}

Little attention has, until recently, been paid to the cost of the sanitary factors in milk production, but, in view of the past non-recognition of the relative values of these factors, the deficiency is not serious. Whitaker, of the United States Department of Agriculture, in 1909 estimated the additional cost of complying with certain important items of the Department's dairy score card, and concluded that "a reasonably clean milk is worth 2 cents more than common slovenly milk. The former is safer and therefore cheaper at

* The average price received by the dealer for milk delivered to family trade was $9 \mathrm{c}$. per quart and to retail stores $6 \mathrm{c}$. to $8 \mathrm{c}$.

$\dagger$ †owen, John T., "The cost of pasteurizing milk and cream," U. S. Dept. Agric. Bull. 85, 1914.

$\ddagger$ Rpt. of Senate committee of the 46th General Assembly to investigate the tuberculin test and the pasteurization of milk and its products (as quoted by E. O. Jordan, Trans. XV Internat. Congress' on Hyg. and Demography, 1912, vol. IV, p. 637). 
the increased price." * With more efficient inethods of producing clean milk, based on the present better understanding of the importance of certain items, the cost of sanitation may be reduced. Such methods are now, fortunately, illustrated by the system of Dr. North, who found the additional cost necessary to supply a tuberculin-tested milk with a bacteria count under 30,000 at time of delivery to be one and one-half cents per quart (see pp. 81-82). The extra cost of a non-tuberculin-tested but pasteurized clean milk would be, on this basis, not more than one cent.

\section{PRICES, WHOLESALE AND RETAIL $\dagger$}

Wholesale prices for milk vary greatly according to place, time of year, and economic conditions. There are a number of different systems of payment in use-according to the can (of various content), hundredweight, butter-fat, etc. General figures compiled by the United States Department of Agriculture $\ddagger$ from milk dealers throughout the country show that the average price paid to farmers in 1912 was 3.57 cents a quart; in 1913, 3.85; and in 1914, 3.80 (figures net at farmers' shipping stations). The average varied in 1914 from a maximum of 4.20 in December to a minimum of 3.26 in June. The highest prices were paid in New England (average, 4.66) and the lowest in the Mountain States (3.45). The highest monthly average was in New England in November (5.05) and the lowest in June in the Middle Atlantic States (2.84). One dealer in the latter region reported that he paid only 90 cents a hundredweight for milk in June,

* Whitaker, George M., "The extra cost of producing clean milk," Bureau of Animal Industry, U. S. Dept. of Agric., Circ. 170, 1911 (reprinted from 26th Ann. Rpt. Bur. An. Ind., 1909).

$\dagger$ For more recent prices later publications from the sources mentioned may be consulted. Those quoted are the most recent obtainable at time of writing.

$\ddagger$ Weekly News Letter to Crop Correspondents, Jan. 20 and April 28, 1915. 
which would be only a little more than 1.9 cents a quart. The above figures are quoted to give an idea of the variations commonly met with.

In publications of the Federal Department of Labor * may be found the average wholesale prices of milk in the New York market for a series of years: Taking the average for 1890-99, 2.55 cents (net price at shipping stations subject to a freight rate to New York of 26 cents per can of 40 quarts), as the base $(=100)$, the relative price figures are as follows: $1900-04,108.8 ; 1905-09,124.8 ; 1910-14,139.3$; 1915, 139.2. The actual average price in 1915 was 3.51 cents per quart at the stations shipping to New York and 3.76 at those shipping to Chicago.

The average retail price of milk in certain representative cities of the United States has been as follows: 1890-1900, 6.8 cents per quart; $1901-05,7.1 ; 1906-10,8.1 ; 1911-15$, 8.9; December, $1915,9.0 . \dagger$ The average retail price paid to producers in the United States, derived from figures of the Department of Agriculture, $\ddagger$ was, for 1915, 7.1 cents per quart; for 1916 (eleven months), 7.3. Comparisons showing the smaller increase in the retail price of milk as compared with certain other important food products have been given in Chapter IV.

* Bull. 81, Bureau of Labor; Bull. 181, Bureau of Labor Statistics; Bull. 200, Bureau of Labor Statistics, July, 1916.

† Bull. 197, Bureau of Labor Statistics, June, 1916.

$\ddagger$ Information by letter. 


\section{APPENDIX E}

\section{LOCAL EXPERIENCES AND INVESTIGATIONS}

\section{NEW ENGLAND}

The milk question in all its bearings has for years been a subject of difficulty and controversy in New England. This region, in which large industrial communities have grown up, drawing their milk supplies from ever widening circles, shows doubtless the most acute milk situation to be found anywhere in the United States, and one never so acute as at the present time.

In Massachusetts the population is increasing at the rate of twenty per cent per decade, yet the number of milch cows has fallen off in the past ten years by eighteen per cent. There has also been a decrease in milch cows in neighboring States (see Appendix A). Concerning this phenomenon the Chief of the Massachusetts Dairy Bureau has had the following to say:-

The elimination of unprofitable dairy cows and the dropping out of unsuccessful dairymen, for whatever cause, as well as the inevitable reduction of the milk supply to such a point as will bring the price of milk to a profitable figures, are but the results of an inadequate price for milk.

The decline in the number of cows is greatest in those localities where milk is shipped by rail to large cities for consumption. It is, therefore, perfectly natural that nearby localities are first to be affected. This decline, however, does not stop, but goes on and on no matter how far the area of milk supply is extended, and the near future will undoubtedly see further decline, especially in northern New England and even in Canada until milk producers come to a realizing sense of the great fundamental fact that milk has been too 
long sold below cost price. Milk production will decrease until the great law of supply and demand does its share of the work in rectifying the situation. The remedy, so far as we are concerned, is the education of the consumer to the food value of milk as compared with other animal foods, together with the education of all to the exact knowledge of the producer's position. Greater economy in milk production must be practiced. Better cows, more scientific feeding and improved business methods are urged of the farmer. Economy in handling, especially in the method of distribution, is urged of the distributer, and a sense of justice and willingness to pay a fair price for milk is urged of the consumer.*

It may be added that there is a feeling among Massachusetts producers that they have been under stricter supervision, entailing greater trouble and expense, than those sending milk from outside of the State, without correspondingly greater compensation; and this feeling has further complicated the situation.

The New England milk problem, centering about the city of Boston, has been subjected in past years to a number of general or limited investigations, by the Federal Dairy Division and by other investigators, mainly from the sanitary side. In 1914 the whole matter was taken up afresh by the Boston Chamber of Commerce, which, through its Committee on Agriculture, made a thorough investigation of all phases with special reference to economic and business conditions. The reasons and scope of this inquiry were as follows:-

It has been apparent for some time that the production and distribution of milk in the New England States is not on a sound economic basis, and that there is something radically wrong with the way in which this important industry is now being conducted. It is obvious that the opportunities in the industry are far from being fully realized.

*62d Ann. Rpt. Sec'y Mass. State Board of Agriculture, for 1914, p. 424 . 
Milk has always been a staple article of consumption with all classes, and is among the best and cheapest foods on the market. The large cities of southern New England would naturally look to the adjoining territory for their supply. This territory (northern and central New England) is well able to support a flourishing dairy industry-and dairying should naturally be the largest single branch of New England agriculture, our greatest single industry.

Generally speaking the per capita consumption of milk in the United States has been steadily increasing; but in certain districts of New England the per capita consumption has been decreasing for the past ten years, and the amount required has been drawn from a larger and larger territory, and from districts more and more remote.

In short, despite the increase in our urban population, the output of the principal agricultural industry in the immediate adjoining territory has declined. Country districts, which ought to be flourishing, are at a standstill. No one has appeared to understand the cause of the difficulty, or to have comprehensive ideas for its solution.

The Committee on Agriculture of the Boston Chamber of Commerce, in view of this situation and at the request of the New England Milk Producers Association (an organization of about 2,000 New England farmers), has made this investigation in the hope of being able to throw a strong light upon the fundamental causes of the difficulty and of being able to work out suggestions for its solution. This investigation has been conducted in coöperation with the agricultural agencies of the various New England States. The Federal Department of Agriculture also has rendered assistance in the transportation features.

It appeared necessary, first, to obtain exact facts as to conditions now existing in New England regarding production, transportation, inspection, grading and distribution; second, to make a thorough analysis of this information, studying the methods adopted by railroads and cities elsewhere; third, to make, if possible, recommendations helpful in putting the industry on a sound basis.

The report has two divisions. The first outlines the present conditions in each phase of the industry, undertaking to give the reader a mental picture of how milk and cream are produced, 
transported, processed, inspected, graded and distributed, and giving the costs and principal problems connected therewith: the second contains comments and suggested recommendations.

The resultant report is an exceedingly valuable document to all concerned in readjustment of the milk industry, being packed with data which are not only of local application but are of comparative and suggestive importance for other regions where similar investigation may be needed. It may be noted in passing that one of the principal points brought out was the lack of standardization and grading of milk which has been the main theme of the present volume. To attempt to quote or abstract from this report further than we have done elsewhere would hardly do it justice; the inquiring reader is therefore referred to the original publication.*

The subject of railroad rates for milk and systems of shipping, having reached an acute stage, was taken up by the United States Interstate Commerce Commission in a long series of hearings held in Boston in February and March, 1916.†

The chief milk measure before the Massachusetts Legislature in 1916 was a bill prepared by the State Department of Health, on the basis of extensive investigation, providing for the formulation by the Health Commissioner of regulations involving the grading of milk throughout the State by a plan applying progressively in communities of different sizes over a period of several years. The agricultural interests, however, preferred no general legislation, and had their way, the bill finally being defeated.

* "Investigation and analysis of the production, transportation, inspection, and distribution of milk and cream in New England," Boston Chamber of Commerce, July, 1915. The Chamber has also issued a pamphlet showing in detail how grading may be carried into effect.

$\dagger$ "The New England milk case," Supt. of Documents, Washington, D. C. $(5$ cts.). 
The question of milk prices in New England reached a crisis in the fall of 1916, as the result of demands by organized producers for a higher price from the dealers. As a result of the controversy, which centered in the Boston market, where an effort was made to withhold milk, some price increases were obtained. At the same time the retail price was raised by Boston dealers to ten cents. More recently (1917) the producers have obtained a further increase in summer wholesale price, and the retail price of staple market milk has gone to eleven cents. Costs of feed and farm labor are reported to have risen greatly in the last year; hence the farmers' demand for the higher price. There is evidence of increasingly effective organization among the farmers of this region.

Very full data regarding the milk situation in Massachusetts, embracing conditions in the milk-producing districts of New England, with discussions bearing on the general milk problem, have recently been published by a special board of the State Department of Health.*

\section{NEW YORK STATE}

Reference has been made, elsewhere in this volume, to the system of sanitary grading prescribed for the towns and cities of New York State (other than New York City) by the State Sanitary Code. This, so far as the writer knows, is the only state system that has thus far been established, and its working is being watched with interest. The New York City system has also been referred to. (See Appendix B.)

The aim of a statewide system of grading is to secure a desirable uniformity of standards and to induce communities which would otherwise remain apathetic to strengthen

* Report of the Special Milk Board of the Massachusetts State Department of Health, 1916. 
their milk supervision. Confusion and demoralization in the milk trade through the adoption of differing local standards are thus avoided. As long, however, as local organization and resources, particularly as to laboratory facilities, remain deficient, effective grading throughout a State cannot become an accomplished fact. The logical function of state authorities is to supervise adequately the supply of each town until it reaches the town confines, but in any case final tests and the enforcement of grading are matters of local control.

The economic difficulty has recently become acute in New York State. The Legislature of 1916 authorized a special committee to investigate the market conditions of agricultural products in general, including milk as a subject of chief importance. Senator Charles O. Wicks, introducing the resolution, is reported to have spoken as follows:-

"The farmers," he said, "are getting less for their milk than they were getting two years ago, despite the fact that the price of feed and the wages of their help have soared in the meantime. The farmers are compelled to sell their milk for less than three and onehalf cents a quart. I do not know whether it is due to a combine of the big middlemen or not, but I do know that the dairy farmers are suffering severely and that many of them are being forced out of business.

"A situation might thus readily arise which would be very serious to the consumers in such large communities as New York City. Something should be done to remedy the situation." *

The above-mentioned committee is interested in markets, prices, and methods of marketing, including economic questions connected with the milk industry.

The price controversy between producers and dealers in the New York market came to an acute issue in the fall of 1916. The organized producers withheld large quantities

* New York Times, April 4, 1916. 
of milk, cutting down the city's supply at one time to little more than a third of normal, and threatened to attempt to establish a coöperative distribution system through the medium of the State Commissioner of Foods and Markets. The boycott resulted in victory for the farmers, the dealers granting the cent-a-quart increase demanded.

\section{NEW JERSEY}

Under a law reorganizing the State Department of Healthh, provision has been made for the adoption of a state sanitary code, which, when drawn, will include milk regulations. These, at present writing, have not yet been published.

\section{RHODE ISLAND}

In 1915 a special commission was authorized by the Legislature to inquire into the agricultural resources of the State. A large share of the attention of this Commission was devoted to the milk and dairy problem. In a recently published preliminary report* the Commission says:-

The situation in respect to this industry is serious . . . there is general dissatisfaction, (1) on the part of the producer because the dairy business is on the whole unprofitable, and (2) on the part of the consumer because of the poor quality of milk furnished by the producer. From the standpoint of health also there is profound dissatisfaction.

The Commission recommends measures for excluding tuberculous cattle, for improvement of stock, and for instruction of dairymen. Attention is called to the decrease in milch cows in the State and the tendency to go out of the State for milk.

* Preliminary Report of the Commission of Inquiry into the Agricultural Resources of the State, Providence, 1916. 
There are many reasons for this decrease in the number of cattle, but they may all be summed up in the statement that the keeping of cattle has ceased to be profitable under present conditions. The demand from the cities for improvement in the quality of milk has not been met, simply because the average farmer who sells his milk to a middleman cannot make dairying pay. . . . To-day the whole subject is misunderstood both by producers and consumers. Whether rightly or wrongly, consumers believe that milk should be delivered to them at a price not more than nine or ten cents a quart. Any attempt to raise that price will only result in a lessened consumption, an end not to be desired if we consider the food values of milk and the health of children.

Believing that "the trouble arises chiefly from the middleman, who purchases at low rates from the producer milk both good and bad, mixes these, averaging their butter-fat contents, and then sells a low-grade milk at a large profit," the Commission makes the following radical recommendation:-

In view of these facts your Commission therefore recommends that cities or urban centers having a population of over 5,000 be required to establish municipally owned central milk depots, convenient to transportation centers, and to allow no milk whatsoever to be sold within their limits before it has passed through these depots for standardization and pasteurization, under the supervision of their Boards of Health, in accordance with rules approved by the State Board of Health.

This recommendation does not apply to the smaller towns, whose milk supply is as poor, if not poorer, than the supply in cities. Some arrangement, however, can easily be made, either to have the milk of the towns standardized at the nearest city depot or to let certain towns, in combination or separately, set up depots of their own.

The Commission "believes that no solution of the milk problem is worth while unless it insists on a thorough standardization, so that each consumer may know exactly what he pays for in purchasing milk," and recommends the classifica- 
tion of milk in four market grades, all of which, except the highest, must be pasteurized at the central milk depot. The lowest of these grades is ultimately to be dropped. The question of distribution is discussed and it is proposed that the privilege of delivery by districts be sold or auctioned in each municipality.

Whether this plan by which the community supersedes the individual in the sale of milk will be put into operation and whether it can be justified as a legitimate exercise of the police powers of the State remains to be seen. It is perhaps most interesting as a commentary on conditions which have been thought to call for so drastic a remedy.*

\section{MILWAUKEE}

The following interesting account of recent developments in the milk situation in Milwaukee has been received from Mr. F. W. Luening, Deputy Commissioner of Health, under date of January 28, 1916: - $\dagger$

Our local problems here have most recently revolved about the question of the tuberculin test and pasteurization. There are incidentally, questions concerning the merits of clarification, and to us the big question of public understanding and coöperation.

Milwaukee some years ago enacted an ordinance requiring that all milk sold in the city come from tuberculin-tested herds. An injunction was promptly served, prohibiting the city from enforcing this ordinance. An organization of milk shippers then took the matter into the courts and delayed enforcement for a number of years. The case was carried from a first hearing in the presence of a court commissioner to the supreme court of the United States. In every instance the city had the better of the argument. When

* Cf. the discussion on municipalization, Chapter V.

$\dagger$ In the course of his study the author has had correspondence with a number of officials in different towns and cities. Some of their remarks by courtesy of the writers, are reproduced here as furnishing useful first-hand information. 
the final decision was rendered by the supreme court of the United States, an attempt to enforce the provisions of the ordinance was made. There was an immediate strike of milk shippers. They refused to ship milk to Milwaukee, and succeeded in curtailing the supply appreciably. The larger dairy companies, however, would readily have won this battle had they actually been concerned in it. It became evident that they were not directly concerned nor that they even desired that the ordinance be enforced. While they managed to procure milk, they took a stand against the Health Department, and with the shippers, succeeded in at least rendering negative most of the favorable public opinion, and took the matter into the Common Council, where a bitter fight was waged on the floor, which finally was won by the Health Department.

The dealers then protested that it was impossible to continue the milk business under existing conditions-that is, with the curtailed supply and the opposition of the shippers.

Ultimately, the department was compelled to procure temporary shippers without the enforcement of the ordinance.

The fight was then taken to the floor of the state legislature, which met in the fall, and there a second long battle was waged, which was again won by the Health Department.

It has not yet been possible to fully enforce the ordinance, however, despite these victories, perhaps as largely because the milk dealer does not want a restricted source of supply as because the shipper does not want to test his cattle. By coöperative work, however, and educational effort, the shipper is gradually coming to see the merits of the test and is no longer the most active opponent. The dealer, on the other hand, appears to see a threat to his source of supply in that the test will restrict the number of shippers and thus permit a comparatively compact body to dictate prices.

The question of pasteurization was incidentally brought up in connection with the test when the dealers contended that their pasteurizers were all-sufficient to take care of any contamination by tuberculosis that might exist in the milk, and by suggesting that a pasteurization ordinance be passed. Eighty-five per cent of Milwaukee's milk supply already is pasteurized, and, although such an ordinance is in contemplation, it has not yet been introduced. 
The broader question of public coöperation was also brought forcibly before us during the recent years and in consequence of the efforts to enforce the tuberculin-test ordinance. The public is negative in the matter of milk purchases. Milk is milk to the average consumer. A white fluid in a bottle with a cream line, is about all he seems to be interested in. In fact, users of milk here, have told us that they could see no difference between the milk from a tuberculin tested herd and the milk from an untested herd. They have explained that the cream line was no lower, that the milk tasted no differently and that they could see no excuse for paying a higher price for such a milk. This attitude, more or less exaggerated, was apparent and general, and, of course, makes for the defeat of a provision like that requiring the test. The dealer can, quite safely, oppose any requirement until the public demands it.

So that the milk question, like most other public health questions, is compelling the Health Department to become an educational institution primarily, and is relegating the police powers to a secondary place.*

The producer also must be made to follow the public understanding of the milk question. So long as milk is accepted by the public, either in urban or rural communities, without question concerning its source, filthy milk will be produced, and the product of the cow will be contaminated until it is hardly fit for food. So long as the public is willing to rely upon strainers, clarifiers and other artificial means of removing dirt, the producer will not concern himself greatly about keeping dirt out of the milk.

The commercial aspects, of course, play a further part, as is indicated in the attitude of the dealer toward the tuberculin test. The milk dealer will always want as wide a market as he can get, as many shippers as he can get and as many other sources of supply, including creameries, cheese factories and other concentration centers. He will always, directly or indirectly, oppose restrictions by authorities or the public, that will curtail his supply. It is not to his advantage to deal with a body of shippers who have complied

* This can rightly be taken to mean only that in practice a great part of the work of effective health departments is educative or suasive rather than compulsive. Authority still remains, of course, the basis of administration.-J. S. M. 
with certain ordinance provisions and therefore are exclusively in a position to supply a particular milk. This would place these shippers in the position of dictators, whereas, under existing conditions, the dealer is the dictator. It is not within the plan of the distributer to permit a concentration of the present scattered sources of supply that are working without coördination, largely without coöperation, and almost entirely without organization. Whether, from a public viewpoint, anything would be gained by placing the power in the hands of the shipper rather than in the hands of the distributer, is questionable, of course. That the producer is capable of assuming an arbitrary and arrogant stand, is evidenced by the milk strikes conducted by milk shippers on two occasions. While it is true that these particular strikes could readily have been broken by the dealers, the public and the authorities working together, it is questionable whether such strikes might not be used to the decided disadvantage of the consumer, were the producers well organized.

\section{BROCKTON, MASS.}

The city of Brockton has for some years been conspicuous for success in bringing about sanitary improvement of milk supplies through regulation based upon bacteriological tests. The city maintains a general municipal laboratory, the Director of which, Mr. George E. Bolling, also Inspector of Milk, several years ago wrote as follows concerning appearance $v s$. results in dairies:-

Our experience in the supervision of our local milk supply has shown us that the appearance presented by a dairy or the score it obtained was not a criterion of the cleanliness of its product, and that intelligent personal supervision by the owner of the detailed work in a dairy essential to the production of clean milk went further toward securing such a product than fancy equipment turned over to hired help. Our motto became "The proof of the pudding is in the eating," and when milk taken from the wagons of the dealers when ready for final delivery to the consumer showed a clean product, we did not insist on more or less costly changes at the dairy that regularly marketed such milk. 
We became convinced, also, that there was an economic side to the milk question and that it vies with the health aspect in importance, for, as runs the famous receipt for rabbit pie- "first catch your hare"-so someone must first produce the milk, and if it is not made a profitable undertaking for someone, who will produce it and then where does the health question enter in?

Our final conclusion was that the proper way to inspect milk was by the laboratory and if anything went wrong an inspection of the dairy became necessary, and that to rule indiscriminately that each dairy must be equipped thusly and score a certain percentage was unnecessary.*

A recent report of the Brockton Health Department states:-

As we have reiterated from year to year, and as further demonstrated by our work in 1914, the high scoring dairy does not necessarily produce the cleanest and safest milk.

Dairymen supplying Brockton have succeeded in producing unusually low-bacteria-count milk in stables of inexpensive construction (see Plate 3, p. 83) and the names of the most meritorious are published in the annual reports of the Health Department. The following statement, in answer to a short list of questions, is furnished by Mr. Bolling:-

1. Sanitary milk inspection for Brockton began in 1906; that year the local board made rules and regulations to supervise the production, care, and sale of milk. Among the regulations was one limiting the number of bacteria in milk intended for sale to 500,000 per c.c. Collection of samples from wagons and stores to determine their relation to the bacterial standard began immediately upon adopting the rule in 1906. The first year about 600 samples were examined by the plate method of counting and in the last ten years 12,300 have been so examined. Persistent violations of this rule have been prosecuted, about a dozen altogether in the ten years. Only such cases have been prosecuted, however, as proved

* "The development of a municipal laboratory," American Journal of Public Health, June, 1912. 
to be unamenable to advice and instruction how to produce cleaner milk. Since 1909 the Statute standards of solids and fats have been enforced, about 1,500 to 2,000 chemical examinations being made yearly.

2. We have no "milk problem" here that I recognize as such. The one matter in which I would like to see a change is for the public to be more willing to pay a higher price for the cleaner milk. This would be automatically brought into effect by sanitary grading.

3. From the standpoint of a health official I would say the most important single regulation is the one limiting the bacterial content of milk intended for sale.

4. As regards pasteurization I believe that the New York system of grading as well as the scheme just proposed by the Massachusetts State Health Department will both serve admirably to induce quite general pasteurization. I believe it should be generally required and that we can hardly err in so doing.

The retail price of milk in Brockton is nine cents, which implies that sanitary improvements have been brought about without excessive increment of cost.

For a city with a raw milk supply, Brockton has been unusually free from traceable outbreaks of milk-borne disease. In 1915, however, two such occurred, involving (though promptly checked) some 48 cases; *-merely another demonstration of the fact that city milk supplies, however clean in the ordinary sense, may carry infection unless efficiently pasteurized.

\section{PALO ALTO, CAL.}

As an illustration of experience in a small community, Palo Alto, Cal. (population ca. 6,000), may be taken. Mr. Harold F. Gray, the former Health Officer, $\dagger$ has kindly furnished some particulars. This community relies upon tuber-

\footnotetext{
* Personal communication, Mr. Bolling.

$\dagger$ Now Asst. Health Officer, San José, Cal.
} 
culin tested clean raw milk for its supply. Concerning the introduction of the tuberculin test Mr. Gray writes:-

We had practically no real difficulty. The campaign for tuberculin-testing, with pasteurization as an alternative, was gradual, and began shortly after the very severe milk-borne epidemic of typhoid fever in 1903. At that time the Board of Health employed a veterinarian to tuberculin-test the various dairy herds. There was no local authority, however, to compel the elimination of reactors, some of the dairymen getting rid of them and some retaining them. At this time most of the milk sold at from 5c. to 6c. a quart, retailed.

This test, however, called the attention of the local public to the situation, and several of our more progressive dairymen began the annual testing of their cows and advertised the fact, obtaining a higher price for their milk. As time went on, more of them followed suit.

The history of the campaign for better milk is summarized as follows:-

Near the end of 1910 under a new city charter, the Board of Public Safety installed a modern health department, directed by a nonmedical but technically trained health officer, who began an aggressive campaign for a better milk supply. The great majority of dairymen tested their herds, and when the writer took office at the beginning of 1914, there were only three large and one small dairies remaining untested, and of these one large dairy had tested, but had not excluded the reactors.

About the middle of 1914 . . . I obtained from the City Council an ordinance compelling either tuberculin-testing or pasteurization. For a while some pasteurized milk was sold in Palo Alto, but eventually this was discontinued for the reason that the public preferred the raw milk.

I am very aware of the great merit of pasteurization as a measure of safety against milk-borne epidemics in cities where a close supervision of the milk supply is not possible. In Palo Alto, however, we are able to supervise our dairymen so closely that the danger of milk-borne epidemics is practically negligible. As a further pro- 
tection in the new ordinance which we are now drafting, to make our local ordinance conform to the new state dairy law which goes into effect on October 1st, we are providing that all employees engaged in the production of the higher grades of milk shall have at least an annual medical examination.

I am sure that at the present time none of our local dairymen would want to return to the old conditions, even though some of them bucked against the changes pretty hard. The public has supported us in our work and, so far as I know, has not objected, except in some few rare instances, to the increase of retail prices. At the present time the better grades of our milk are retailed for 10c. a quart and few dairies still supply a small amount of milk at $8 \frac{1}{3}$ c. a quart. The probability is that after the new law goes into effect guaranteed milk will sell for about 11c. or 12c., grade A, 10c., and grade $\mathrm{B}, 8 \frac{1}{3}$ c. a quart.

Some effort was made to obtain exact financial data regarding the relative cost and profit in producing high-grade and low-grade milk, but little information was forthcoming from the dairymen.

Several stated to me, however, [writes Mr. Gray] that their net profit was considerably larger for the production of good quality milk as against poor quality. They based this statement on these factors: *

(1) The better care of the dairy cows meant an increased production per cow, the value of which increase was much in excess of any expense of additional feed.

(2) The greater interest in quality has led to a greater interest in production per cow (as well as practically compelled it), so that they have weeded out the "boarders" or unproductive cattle.

(3) A higher grade milk has commanded higher prices, both wholesale and retail.

It is to be wished that such results were more frequently the case.

* These evidently refer to general care of cows and food quality of milk as well as to sanitation.-J. S. M. 


\section{MONTCLAIR, N. J.}

The town of Montclair, N. J., was the pioneer in the United States in official work for clean milk, and has, under a succession of trained health officers, brought its milk standards to the culmination of obtaining a tuberculin-tested milk of high sanitary quality. At Montclair the legal question of the tuberculin test was conspicuously fought out, with the result that an important victory was won by the Board of Health and the legal status of the test firmly established. In previous pages reference has been made to Montclair on several points. For further information the reader is referred to the annual reports of the Board.

\section{RICHMOND, VA.}

Strict regulation aiming at clean milk has also been practiced for some years in Richmond, Va., under the direction of the Health Officer, Dr. E. C. Levy. Nearly half of the market milk in this city runs under 10,000 bacteria per c.c., and 83.3 per cent of it below 50,000. The infantile diarrhea death rate has declined remarkably, year by year, for the last four years, though Dr. Levy remarks that he does not hold "the primitive view that the milk supply is everything in this connection or, indeed, that it is, in all probability, the most important single thing." The classification of milk recently adopted by this city, (see Appendix B) shows the requirement of pasteurization of milk not of the first grade.

\section{WINNIPEG, CANADA}

Dr. A. J. Douglas, Medical Officer of Health, writes as follows:-

From the experience I have had, my personal view is that pasteurization offers the most satisfactory solution of the problem of how to secure a safe milk. In this city at least I do not see how the 
situation can be adequately dealt with in any other way. This department has endeavored for the past fifteen years to educate producers and to point out the advantages, both to producer and to consumer, of clean and safe milk. . . . At the present time possibly eighty per cent of our local supply is pasteurized, and we know that this process is adequately carried out, as we keep an inspector on the floor of each plant. A few years ago no pasteurized milk was sold here. At that time a year never went by without one or more outbreaks of disease, usually typhoid, which could be traced unequivocally to the milk supply. Since pasteurization has come extensively into use some four years ago, we have not had a single outbreak of disease which we could prove was milk-borne.

\section{MILK SUPPLIES OF TEN EASTERN CITIES}

Several years ago the Jersey Bulletin* collected some interesting information and figures regarding the milk supplies of New York, Philadelphia, Boston, Cleveland, Buffalo, Providence, Columbus, Toledo, Hartford, and Burlington, Vt., published in an article concluding as follows:-

In summarizing, it will be seen that the average price paid per quart by the consumer in all the ten cities is about $73 / 4$ cents. While specific information regarding the price received by the producer was not obtained in every instance, it is plain to see that it averages close to $3 \frac{1}{2}$ cents a quart, or less than half the retail price. In other words, the farmer or the dairyman has to keep up his farm, maintain his cows, feed them, milk them and see more than 50 per cent of the final receipts go into others' hands, while his receipts, in many instances, barely pay the cost of production.

As to the tuberculin test, the average opposition to rules laid down by health boards in this regard seems to be about 98 per cent; though of course this does not apply in the case of certified producers. The feeling of the farmer producing market milk has always been antagonistic to strict regulation by city authorities, and no doubt always will be just so long as he is given no monetary inducement to practice better methods.

The fact remains, however, that the average standard of the milk

* Jersey Bulletin and Dairy World, Indianapolis, Aug. 23, 1911. 
supply of our large cities has greatly improved in the last few years, and even though the methods used in bringing this about have been in many places strongly objectionable to the producer, the results have directly or indirectly been generally successful; and now that the public has become better educated to the value of good milk, it remains for the farmer or producer to impress this fact more strongly than ever by keeping up the quality, to the end that he may receive for his milk not only what it costs. him to produce it, but a reasonable profit thrown in.

\section{THE DAIRY SITUATION IN FREDERICK AND BALTIMORE COUNTIES, MARYLAND}

All of the general positions taken in this book have been strikingly confirmed in an intensive survey, made during the summer of 1915, of the milk situation in Frederick and Baltimore Counties, Maryland. This survey brought out exceedingly important points, and, since similar conditions prevail in many other regions, has more than a local interest. Hence a summary account of it is here reprinted entire. The investigation was made by the Women's Civic League of Baltimore, in coöperation with the dairymen, through an investigator qualified to deal with agricultural questions. The findings involve an interesting comparison between differing conditions in the two counties: at the same time they may be compared, as a small-scale survey, with the large-scale survey in New England by the Boston Chamber of Commerce which has already been referred to. The analysis of the sanitary and economic questions centering about the price of milk is the pervading characteristic of the report, which we quote without further comment: *-

The purposes of these investigations were two: (1) To secure the point-of-view of the man behind the cow in things as they are in

* Reprinted from The Town, organ of the Women's Civic League, Baltimore, Md., June 10, 1916. The report is based, with omission of some details, on two earlier reports. 
the milk business and to record his suggestions for the improvement of these things; (2) To secure facts and figures relative to the actual cost of production, selling price and profit or loss among the dairymen. This information should serve as a basis for intelligent legislation.

Those farms selling milk direct into Frederick City were believed to serve best the purposes of the survey, and it was from these 47 dairymen that the 25 units of the survey were selected. They presented a problem purely productive in nature and uncomplicated by long hauls to distant markets.

IS DAIRYING YOUR SPECIALTY OR JUST A SIDE-LINE? With all of the 25 men, except 2 , who sold to retail trade, the milk business was merely a side-line.

Is IT BETTER OR WORSE THAN IT USED TO BE? Only 2 thought it better, 16 declared it worse, and 7 thought it just about the same.

DO YOU WEIGH THE MILK FROM EACH COW AND TOTAL HER PRODUCTION? Only 1 of the 25 took this business precaution.

Do YOU KEEP FARM BOOKS? Only 2 of the 25 kept farm books.

The next three questions established the fact that the average dairyman had to get up about four in the morning and that many milked by lantern light. The average working day was $14 \frac{3}{4}$ hours!

The TUBerculin TEST had but 7 converts and many of these qualified their declaration with, "but not as it is done down here." Eighteen were dead against it. There were no neutrals.

ARE THE PRESENT MILK LAWS FAIR TO THE INTERESTS OF THE FARMER? Upon this point there was a great unanimity of opinion. Only 3 men believed that the farmer was getting a square deal, while 20 were loud in protestation to the contrary. Two were neutral.

Does DIRTY MILK CAUSE DISEASE? There were no neutrals on this point; 15 believed that dirty milk might cause disease or even death, but 10 denied that such a danger existed.

MilK PRODUCED PER COW PER YeAR, 5,943 pounds. The average of the State is about 3,500 pounds. This average is very low and capable of being doubled and then doubled again.

COST OF PRODUCTION PER QUART OF MILK: The amount of milk produced and the cost of production: These two factors control in so far as the producer is concerned, the extent of his profit or loss. 
Yet only one farmer out of 25 was able to approximate the amount produced, and not one was able to even hazard a guess at his production cost. Which represents the main distinction between the "milk business" and simply "shipping milk."

TO PRODUCE A QUART OF MILK COST, on the average, 3.5c. (14.0c. per gallon the year through.)

The AVERAGe SELling PRICE PER QUART was 3.8c. (15.2c per gallon the year through.)

It will be at once observed how small is the margin of profit from the sale of milk alone. Nevertheless, of all the 25 dairymen, only 5 were actually losing money, and the value of calves and manure produced redeemed 3 of these to the extent of just about breaking even.

Although 20 herds were making some money, very few were making their owners rich or even adequately compensating them for trials and tribulations undergone. The average dairyman ended the year about $\$ 330$ ahead-a little less than a dollar a day profit from the sale or utilization of both milk and calves. To this may be added the value of manure produced by each cow during the year.

Average PROFIT PER COW PER YEAR: From milk and calves sold or utilized, this profit was $\$ 17$.

WHAT IS WRONG WITH THE MILK BUSINESS?

THE LAws were attacked by 12 farmers, mainly on the grounds that they were written from a citified viewpoint and likewise enforced; that they raised expenses without raising prices; and that they were inefficiently administered.

INADEQUATE PRICES had six adherents. Most of these took the stand that if the towns want better milk they must pay better prices. They called attention to the fact that the price of feeds, fertilizer and labor has almost doubled during the last decade and that there has been no corresponding increase in the price of dairy products.

The MidDleman was attacked by only two of the 25 .

What SUGgestions HAVE YOU TO MAKE THINGS BETTER? Answers on this point were vague and varied. Those who held legislation at fault wanted "better laws;" those who complained of "poor prices" wanted "better prices;" and the two who were against the 
middleman advocated direct selling. All agreed that "coöperation" was necessary to secure their several ends.

Does DIRTY MILK CAUSE DISEASE? Undoubtedly it does, and sometimes death, especially amorg infants. To the 10 men who stated their disbelief in any danger from dirty milk, and to any other who may hold a like opinion, we would say: "Ask Your Doctor."

What is WRONG With the MiLK Business? Certainly not all the trouble can be traced to Inadequate Prices. The production end of the milk business is, for the most part, being carried on in an unbusinesslike manner, and the producer himself thus takes rank among the factors which prevent his realizing from his herd all that he is entitled to. We believe that the time will come when every dairyman will find it profitable to produce clean milk and when he will be able to turn to his books to prove the extent and sources of this profit. The first interest of the State should be the industry which feeds the State. The main dependence of Maryland agriculture is the dairy farmer.

We cannot believe that the present milk laws represent the main difficulty, no matter how imperfectly they may have been drafted or unsympathetically applied.

Any one dairyman can of himself reform his own business and, even at current conditions and prices, make it pay. How? Ask the man who belongs to a Cow Testing Association! Of course, a man does not have to join a Cow Testing Association; he can weigh the milk, make the tests and figure the results for himself. But, if he is to make money out of dairying nowadays, he must do one or the other.

Baltimore County showed an encouraging degree of enlightenment and fairmindedness in regard to the latter-day features of the business. Where Frederick County farmers had gone on record as in favor of only about one-third of these things, Baltimore County declared for 80 per cent of them.

Frederick County produced its milk more cheaply and made more money from its herds. Its production cost was only $3.5 \mathrm{c}$. per quart as compared to an average quart-cost of $4.5 \mathrm{c}$. in Baltimore County. And to this latter cost may be added 0.5c., the quart-cost of "milk tickets," a thing unknown in the field of the Frederick 
County investigation, where the shippers sold directly into Frederick City. This half-cent transportation charge is not, strictly speaking, a part of the Production Cost, but it does represent a substantial part of what might be called the Producer's Cost, and so should be counted in. If it be so considered, the Baltimore countian averaged an expenditure of 5.0c. for every quart of milk produced. Of course, this does not apply to the few who shipped to a creamery or supplied a small local trade.

An $(\dagger)$ after a figure means that this figure is greater than the corresponding result of the Frederick County investigation; a minus-sign means that it is less.

IS DAIRYING YOUR SPECIALTY OR JUST A SIDE-LINE? Fifteen (-) thought the business a side-line; ten decided it was a specialty.

How LONG HAVE YOU BEEN IN THE MILK BUSINESS? The average was 18 years $(\dagger)$.

IS IT BETTER OR WORSE THAN IT USED TO BE? Two thought it better; $19(\dagger)$ worse, and four either had no opinion or thought it just about the same.

DO YOU WEIGH THE MILK FROM EACH COW AND RECORD HER PRODuCTion? Five ( $\dagger$ ) of the 25 took this business precaution.

Do YOU KeEP FARM Books? Ten ( $\dagger$ ) of the 25 kept books.

THE WORKING DAY was thirteen and one-half hours, more than an hour less than that of the Frederick County dairymen, but quite a day at that.

WOULD YOU RATHER SELL TO A CREAMERY OR DIRECT TO TOWN AT A BULK PRICE? Twelve ( $\dagger$ ) preferred the creamery and ten shipping to town. Three had no preference.

ARE the PRESENT MILK LAWS FAIR to THE INTERESTS OF THE FARMER? Three thought the laws all right; eight, among whom was a lawyer, declared them unfair, and 14 held no opinion.

NUMBER OF COWS PER HERD: The average was 30 ( $\dagger$ ).

POUNDS OF MILK PRODUCED PER COW PER YEAR: 5,089 (-). Equivalent to less than two gallons per day for a period of 365 days.

TO PRODUCE A QUART OF MILK COST 4.5c. (†). (18c. per gallon the year through, to which may be added 2.0c., the gallon-cost of milk tickets.)

The average selling price per QUart was 4.2c. ( $\dagger$ ). (16.8c. per gallon the year through.) 
PROFIT OR LOSS: With the production price exceeding the selling price a county-wide loss would seem self-apparent. This loss, however, is slightly more than redeemed by the value of calves and manure produced. The farms included in the survey were, in almost every individual case and on the average, just about breaking even.

From the sale and utilization of milk and calves there was an annual average loss per cow of $\$ 6$; a loss offset by the manure which a cow will produce in a year. So it seems that Baltimore County is just about breaking even from its efforts to supply Baltimore City with milk.

Aside from the fertility factor-an important but not a very tangible reward-the only other excuse for being in the milk business seems to be the monthly check. This is an undoubted advantage. In the present absence of any logical system of rural credit many farmers are practically banking with the milk middleman; pouring in their daily deposits of value and drawing out in cash at the first of the month.

What is WRong With the MiLK Business? This question, put to 25 Baltimore County dairymen, elicited 23 decided opinions.

One dairyman writes, "Allow me to predict that, if conditions are not soon bettered, most of the men now engaged in the milk business will be forced out of it."

Where in Frederick County the disposition was to lay the blame upon the present laws, Baltimore County was practically unanimous in blaming the system of marketing.

Sixteen thought the present prices paid for milk to be insufficient in view of the constantly growing production cost-a belief somewhat supported by the facts obtained. Six attacked the middlemen. One man thought the trouble to be in "over-production" and counselled combination in view of finding "some method to take care of the surplus."

What sUgGestions have You to MAKe things BetTeR? The great majority of answers to this question simply advocated a "fair price." Some specified this price to be " $20 \mathrm{c}$. in summer and $25 \mathrm{c}$. in winter, showing that the farmers have at least an idea of what it is costing them to produce the milk they are selling for 16.2c."

"Milk should be graded as is the case of all other foodstuffs," 
writes one large producer and two others say almost exactly the same thing.

Apropos of the condition and correction for the condition of the milk business are the remarks of one of the largest milk middlemen of Baltimore, made recently in the presence of a representative of the League:

The MidDLeman's view-Point: "Farmers often come to me and say, 'I'm losing money by selling milk. I've got to have a better price.'

"'How much money are you losing?' They don't know. 'Don't you keep books?' No; they never bother with them. They don't weigh their milk and keep account of their individual cows; their herds are full of star boarders, eating their heads off. Very often they don't have silos; they don't try to raise all of their own feed, and they don't feed intelligently. Their product is poor and often below city standard. No wonder they are losing money!

"Some farmers producing milk testing high in butter-fat, low in bacteria, and who have their cattle tuberculin tested every 12 months are getting now, an advanced price."

"A general rise in the retail price of milk, however, is next to impossible in the light of present public opinion.

"It is true that the margin of profit is small; the only way for the producer to make money is through more economical methods and 'better cows."'

The wide difference of opinion between the producer and the seller of milk is at once apparent. They see the thing from entirely different angles. Broadly speaking, each blames the other. It is important to note, however, that the middleman quoted was in complete accord with the several producers who advocated a system of graded milk-a practical point in favor of the system.

It seems obvious that the dairy business can easily be systematized and improved so that much larger profits will be earned. Then the dairy farmer can satisfy the demands of the consumer and can, when the legitimate costs justify it, ask a larger price for his commodity. The consumer should be willing to pay a fair price for safe milk, but he should not be asked to pay for a high cost of production due to inefficient methods.

RUSSELl R. LORD. 
Limitation of space forbids further mention of conditions in individual localities. A great many special investigations have been made, some by the Federal Department of Agriculture, some by state or local authorities or individual investigators. The preceding condensed statements are intended to be merely illustrative of varying local situations and individual comment.

\section{COÖPERATIVE PASTEURIZATION AT RIVERSIDE, CAL.*}

A coöperative pasteurizing plant which has many novel features has been operated for some time in Riverside. While owners of small dairies under the new law, may have their cows tuberculintested, without resorting to pasteurization, it is possible that owners of small dairies may desire to coöperate in the establishment of a pasteurizing plant like the Riverside institution.

Seven dairymen organized the company in Riverside, which was incorporated with $\$ 20,000$ capital stock, $\$ 8,500$ of which was paid in by the organizers. This capital paid-in stock was to draw 7 per cent interest, payable semiannually. A sufficient amount of money was borrowed to buy the property, build the plant and install the machinery. The plant started operating in March, 1911. No stock has been sold since that date and none is held by any one other than a dairyman.

Dr. George E. Tucker, city health officer of Riverside, says of the operation of this plant and of its effect upon conditions in Riverside:

"Before this plan was started, eight dairies were selling milk in the city, with eight wagons making two deliveries a day, and practically every block within one mile square was covered by each of the eight wagons in the early morning and in the evening.

"In July, 1910, milk retailed at eight and one-third cents per quart. In November, 1910, the price was raised to ten cents per quart. A series of tests showed the butter-fat content to vary from 3 to $4 \frac{1}{2}$ per cent, depending to a certain extent upon the convenience of the water supply.

* Bull. Cal. State Bd. of Healtb, May, 1916. 
"After formation of the dairy company, the price was immediately reduced and reductions have continued until at the present time milk containing 4.2 to 4.5 per cent butter-fat is sold for 15 quarts for $\$ 1.00$, or at $6^{2} / 3$ cents per quart.

"Since the formation of this company the number of dairies in the county has doubled.

"All the milk and cream is pasteurized by being subjected to a temperature of from 147 to 160 degrees for ten to fifteen minutes. The milk is first aërated and cooled at the dairies, delivered immediately to the central plant, where it is pasteurized, bottled, reduced to a temperature of between 30 and 40 degrees Fahrenheit in the precooling plant and delivered to the consumer.

"For the purpose of delivery but three wagons are used for the retail trade, whereas formerly the same amount of milk from the same number of dairies would have required fifteen wagons.

"The total investment in this distributing station at the present time represents in real estate, buildings, machinery and improvements about $\$ 31,000$. There is a floating indebtedness of $\$ 11,000$, drawing 6 per cent interest, and accumulated assets of $\$ 9,500$.

"Three dairyman are employed to manage the business at a sufficient salary to justify them in accepting such employment and discontinuing active dairy work. Sweet milk and cream are sold not only in the city of Riverside, but in the adjoining towns.

"There are at the present time ten employees: the three dairymen above mentioned, three men for delivery and three men who operate the plant, and one bookkeeper.

"The advantage of this method of handling the city milk supply is apparent. If at any time it is found on inspection that any of the contributors to this station are producing milk under conditions which are not satisfactory, a notice to the producer from the plant is sufficient to prevent the sale of this milk. The fact that our general milk supply is pasteurized does not in any way deter either the dairymen or the inspectors from insisting upon the production of clean milk.

"I believe that the result of the central dairy plant experiment has fostered and very greatly increased the dairy business; that the dairymen receive more for their products; that the consumer receives a higher grade of milk at a less cost, and that two-thirds of 
the vexatious problems in the control of a small community's milk supply have been solved by the introduction of this plan."

\section{HINTS FOR LOCAL MILK COMMITTEES *}

1. In undertaking to secure better milk for any community it is first important to read the reports of the New York Milk Committee and those of other cities, and it will be found helpful to read the reports of the Public Health Service on milk. Perhaps the most valuable document is the Report of the Commission on Milk Standards appointed by the New York Milk Committee, printed by the United States Public Health Service in 1912 and again in 1913. [A third revised report has appeared in 1917.-J. S. M.]

2. It is also indispensable that by every possible method, committees dealing with milk should know thoroughly the methods of production, from cow to consumer, and the difficulties that beset the dairy farmer and the city dairy companies.

3. But perhaps the most valuable step is that which puts a milk committee in touch with the local public health authorities. It will be found in most communities that both city and state health departments are inadequately manned and equipped to deal effectively with milk problems. Even if this is not true the health department will undoubtedly welcome any agency helping to bring to the attention of the public the rules and regulations of the department, and suggestions for better health conditions.

4. The next step will commonly be to employ an investigator, who has had proper scientific training, to work with the health department in securing a report on the exact condition of the milk served to the public. This can then be made the basis of requests from the appropriating powers for proper men and equipment to take care of the milk situation where it should be handled-in the health department.

* From an article entitled "How a civic league secured a clean milk supply," by Harlean James (Exec. Sec'y, Women's Civic League, Baltimore), The Survey, Jan. 16, 1915. 


\section{APPENDIX F}

\section{MILK PRODUCTS}

The scope of the present volume has forbidden treatment of the various products derived from milk by modern industry. For these the same general considerations hold, so far as may be, as for milk. The pasteurization of the milk from which these products are made, or of the product itself, is very desirable and is, in fact, rather general in practice. The concentration of manufacture in plants of some size is a factor which makes for the readier control of milk products, though the sources of the milk entering into these also call for attention. Through modern economic conditions certain of these products, such as condensed milk, evaporated milk, and skim milk, have come into wide use as substitutes for fresh milk.

The National Commission on Milk Standards (of the New York Milk Committee) has had under consideration certain products-such as butter, ice cream, condensed milk, skim milk, buttermilk, and homogenized milk and cream-and the reader is referred to the reports of the Commission * for information on their sanitary aspects. In the control of these products the principle of correct labelling plays a most important part.

* See 3d. Rept. 



\section{INDEX}

Administration of milk control, 163

Aǵricultural authorities, 52-54, 164-66

Bacteria and milk, 13

Bacteriological tests and standards, 67, 92. See also Laboratory.

Baltimore, 243

Boston. See New England.

Brockton, Mass., 83 (pl.), 236

Butter fat, labelling as to, 92, 154-55; payments for, by - dealers, 144; standards for, see Chemical tests.

"Carriers," disease, 14-15

Central distribution, 139-40, 25052

Centralization, 170

Certified milk, 67

Chemical tests and standards, 89. See also Laboratory.

Cities, "milksheds" of, 39, etc. (figs.); milk supplies of ten Eastern, 242

Clarification, 113; "public value" of, 156

Clean milk, movement for, 66,69 ; rational methods in producing, 76 ; cost of, 158, 222

Communicable disease. See Milkborne disease.

Consumer, 57
Contamination, 10 ; tests for, 97

Contests, dairymen's, 115

Contractor. See Dealer.

Coöperative plans, 170, 250; for farmers' milk depots, 142-44

Cost of milk, factors in, 138, 15758, 221-23; and prices, 157

Cost of milk distribution, 139-40, 221-22

Cost of milk production, 138-39, 214 ; vs. prices, 46-48, 126-33; extra, for sanitary milk, 158, 222

Cream, grading of, 194, 198, 200, 201

Dairy cows, profitable and unprofitable, 135-36; statistics of, 185-88

Dairy demonstration, 161

Dairy score card. See Score card.

Dairying, decline of, in certain regions, 121; inefficiency and waste in, 110 (pl.), 133-38, see also Milk industry.

Dairyman. See Dealer, Farmer.

Dealer, 54, 141; and farmer, 142

Decency, 12-13; "public value" of, 156

Dirt, in relation to milk, 10 ; tests for, 97

Disease. See Milk-borne disease. Distributer. See Dealer.

Distribution, cost of, 139-40, 221-22; plans for improving, $139-40,171,250-52$ 
Economic effects of sanitary regulation, 147

Economic importance of milk, 6-9, 121

Economic question, crux of, 122

Epidemics. See Milk-borne disease.

Exhibitions, 115

Farmer, 46, 122-38; and dealer, 142

Farmers' organization, need of, 51 , 145; for marketing, 170 ; for milk depots, $142-44,170$

Federal authorities, 165

Grades of milk, "public values" of, 156

Grading of milk, 116; need for, 147, 149-51, 152-53; principles and application of, 153-55; systems of, 118, 189; effects of, 150-51, 159

Guaranty system of milk sale, 91-92

Health official, 44

Homer plan, 203, etc.

Homogenization, 114

Infant mortality and hygiene, 15-21

Infant welfare stations, 86

Infection in milk. See Milk-borne disease.

Inspection, 161. See also Score card.

Laboratory, 145 (pl.), 160, 16667 ; tests and standards, 89

Legislation, 167

Legislator, 60
Local differences, 169

Local milk committees, hints for, 252

Local supervision, 163-64, 166; establishment of, 169-70; cóoperative, 167

Maryland, 243

Massachusetts. See New England.

Microscopic examination, 96

Middleman. See Dealer.

Milch cows, profitable and unprofitable, 135-36; statistics of, 185-88

Milk, composition, food value, and use of, 5-9; pecuniary economy of, 6; dangers in, 9-29; fermentation and decomposition of, 13; sanitary, general requirements for, 29. See also Clean milk.

Milk control, by local authorities, 163-64, 166, 169-70; by state authorities, 163-66; relative importance of, 61

Milk industry, primitive and advanced conditions in, 110 , etc. (pls.).

Milk problem, in general, 1-5, 3542 , 61-63; solution of, summed up, 174-76

Milk processes, 114

Milk products, 253

Milk stations, $86-89$

Milk statistics, 185

Milk-borne disease, 14-15, 21-29

Milkman, the old-style, 35

"Milksheds" of large cities, 39, etc. (figs.).

Milwaukee, 233

Montclair, N. J., 241 
Municipalization of milk supplies, $171,172-74$

National Commission on Milk Standards, 189

New England, 142-44, 149-50, 214-20, 225

New Jersey, 231

New York City, grading system of, 197

New York Dairy Demonstration Co., 203, etc.

New York Milk Committee, Commission on Milk Standards of, 189

New York market prices, wholesale, 224

New York State, grading system of, 199; situation in, 229

North system, 78, 161, 203

North's "public value" of different milks, 155

Orange, N. J., 201

Organization, 163, 169-70

Organizations, unofficial, 59; hints for, 252. See also Farmers' organization.

\section{Palo Alto, Cal., 239}

Pasteurization, 102; time and temperature for, 104 (fig.); methods of, 109; requirement of, 110-13; cost of, 222 ; plants for, coöperative, 171, 250; in "public value" of milk, 156

Physician, 59

Politics, 4-5, 60

Prices, milk, general considerations relating to, 157 ; in relation to the farmer, 126, 221; effects of sanitary regulation on, 147-51; retail, comparative, 127-28; retail, and "public value" of milks, 156; retail, stability of, 146; retail, ticket system and fractional prices in adjustment of, 146-47; wholesale, according to quality, 14445 ; in U. S., wholesale and retail, 223

Production, cost of. See Cost of milk production.

"Public value" of differenc milks, 155

Publicity, regarding milk problem, $31-34$; of ratings of milk supplies, 114

"Pure milk," demand for, and publicity, 31-35; practical definition of, 29

Railroads and rate question, 56

Regulation, sanitary, development of, 64, etc.; economic effects of, 147. See also Milk control, Legislation.

Retailer. See Dealer.

Retailing of milk by ticket system and fractional prices, 146-47

Rhode Island, 231

Richmond, Va., grading system of, 200; situation in, 241

Riverside, Cal., 250

Sanitary milk. See under Milk.

Sanitary regulation. See Regulation.

Score-card method of inspection, 70,83

Sediment tests, $97-100$

Standards for milk, National 
Commission on, 189. See also Tuberculosis, bovine, in relation Bacteriological, Chemical tests. to milk supplies, and tuberculin State supervision, $163-66$

Ticket system of retail payments, 146

Transportation problem, 56

Vermont, 149-50. See also New England.

Winnipeg, 241 
THE following pages contain advertisements of a few of the Macmillan books on kindred subjects. 



\section{Public Health Nursing}

BY MARY SEWALL GARDNER, R. N.

Superintendent of the Providence District Nursing Association; President of the National Organization for Public Health Nursing, 1913-1916

WITH AN INTRODUCTION BY

\section{ADELAIDE NUTTING}

Professor of Nursing and Health, and Director of Department, Teachers' College, Columbia University

12mo, 372 pp., index and appendix. Price, $\$ 1.75$

Probably the best description of this authoritative work is contained in the opinion expressed by Miss Nutting in the Introduction:

"Miss Gardner has performed an important service in placing at our disposal the first really comprehensive presentation of so timely a subject as Public Health Nursing, a subject whose development and status are becoming increasingly important as a matter of vital public interest. From the depths not only of a rich experience preceded by a careful training, but of an unusual understanding of, and respect for, human relationships, she brings forth the mature wisdom which characterizes the book. Miss Gardner knows her subject from within-every stage of it. She reveals herself as a woman of quite exceptional administrative insight. Seen through her eyes, complicated situations become clarified, difficulties dissolved, and the work moves easily to accomplishment along well directed lines."

\section{THE MACMILLAN COMPANY}

Publishers 64-66 Fifth Avenue New York 


\section{Principles of Sanitary Science and the Public Health}

With Special Reference to the Causation and Prevention of Infectious Diseases

BY WILLIAM G. SEDGWICK, Рн.D. New York

The direct outgrowth of a course of lectures given for several years by the author to his students.

The author prefers to deal as far as possible at first hand with matters within his own knowledge rather than to depend upon the digests or even the original reports of others.

Discusses the principles rather than the arts of sanitation.

Well adapted for text or reference use in courses on hygiene and sanitation.

\section{Laboratory Guide in Market Milk \\ BY H. E. ROSS}

Professor of Dairy Industry in the New York State College of Agriculture at Cornell University

$65 \mathrm{pp} ., 8 v 0, \$ .60$

It is the purpose of this laboratory guide to enable the student to better understand the application of science to clean milk production, and to impress on his mind the necessity for attention to detail in this branch of dairy industry.

\section{THE MACMILLAN COMPANY

Publishers 64-66 Fifth Avenue New York




\section{Dairy Cattle and Milk Production}

Prepared for the Use of Agricultural Cóllege Students and Dairy Farmers

BY CLARENCE H. ECKLES, B.S.A., M.Sc.

Professor of Dairy Husbandry, University of Missouri

Dairy cattle and dairy farming are assuming a position of great importance in the agriculture of America, and instruction in these subjects is an important part of all courses in agricultural schools and colleges. Professor Eckles's book is prepared primarily for the use of students in agriculture, but the material is so thoroughly practical that farmers and dairymen who wish the most recent knowledge regarding the dairy cow will profit by a reading of it.

The author has brought together from widely scattered sources all the information necessary to acquaint the student or farmer with the principles he must understand and practice in order to be successful with dairy cattle. He takes up ail of the dairy breeds, their characteristics and adaptations. The selection of the individual cow, calf-raising, management of the cow, breeding, stable construction, as well as a consideration of the ailments of cattle, likewise come in for detailed treatment.

The book will render great assistance to the practical farmer interested in dairy cattle, who will find the material presented here in such a way that it will assist him to care properly for his animals and to produce milk economically. For fifteen years Professor Eckles has had charge of a herd of from thirty to fifty cows, including all the leading dairy breeds. For the past ten years he has been teaching in the University of Missouri where he is Professor of Dairy Husbandry. His combined experiences have well fitted him for the task of writing the book on dairy cattle and milk production.

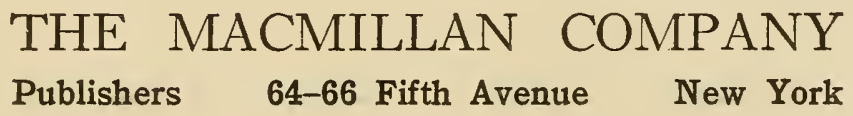




\section{Milk and Its Products}

\section{BY HENRY H. WING}

Professor of Dairy Husbandry in Cornell University

New revised edition. With new illustrations. Cloth, 12mo, $\$ 1.50$

The revolution in dairy practice, brought about by the introduction of the centrifugal cream separator and the Babcock test for fat, by a more definite knowledge regarding the various fermentations that so greatly influence milk, and the manufacture of its products, have demanded the publication of a book that shall give to the dairyman, and particularly to the dairy student, in simple, concise form, the principles underlying modern dairy practice. Such has been Professor Wing's purpose in this work. This is not a new edition of the author's very successful volume published under the same title many years ago; it is, in reality, an entirely new book, having been wholly reset and enlarged by the addition of new matter, both text and illustrations. The author's aim has been at all times to give the present state of knowledge as supported by the weight of evidence and the opinions of those whose authority is highest.

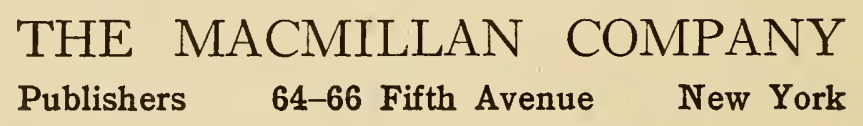







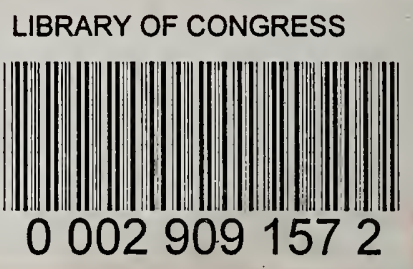

